\title{
Strengthening Local Government and Community Governance in New Zealand
}

by

Michael Reid

\author{
A thesis \\ submitted to Victoria University of Wellington \\ in fulfilment of the requirements for the degree \\ of \\ Doctor of Philosophy \\ in Public Policy
}

Victoria University of Wellington

2010 


\section{Abstract}

The role of local government and specifically the concept of community governance have been the focus of much attention in recent years. For much of its history, local government was typically viewed by governments and citizens as a conservative sector, valued for its dependability rather than for innovation and its services rather than for its role in promoting community well-being. Public sector reform, globalisation and increasing demands by citizens have increased awareness of, and appreciation for, the potential for local governments to work with other organisations to address complex policy and management issues. These pressures have compelled the sector to innovate, and venture into areas that were previously considered to be outside its remit.

Local governments the world over have therefore undergone extensive programmes of reform, often aiming to reorient councils from service delivery roles to broader roles concerned with community well-being, strengthening community leadership, and steering local and regional service providers towards local goals and strategic objectives. This trend has been characterised as a shift from local government to 'community governance' (Rhodes 1997, Stoker 2000).

Local government in New Zealand is no exception. The Local Government Act 2002 (LGA 2002) broadened local government's powers and purposes, introducing a collaborative, citizen-centred style of working within a framework oriented to securing community well-being and sustainable development. This research examines the concept and practice of local and community governance, internationally and in New Zealand. Its focus is the local government reforms introduced in New Zealand over the last two decades, and specifically the role of community governance. It uses several research methods to assess options for strengthening community governance in practice.

The primary method is the development of a model which examines 10 dimensions of the New Zealand system to assess the degree to which they are 
able to achieve community governance. In addition, the approach to community planning undertaken by a sample of local authorities is examined to assess the degree to which councils are using this mechanism as an instrument for strengthening community governance. Further, a number of local government participants were invited to answer a range of questions about three alternative governance scenarios designed to test whether or not there is an 'ideal' local government structure for achieving community governance. 


\section{Preface}

Rapid social, economic and technological change has encouraged governments to review their approaches to governance in order to confront new challenges. The last few decades have seen many countries shift powers and authority previously held by local government to international or community levels. For example, policy challenges associated with climate change have resulted in upward shifts of power to multilateral organisations, whereas policies of decentralising and devolving have led to downward shifts to sub-national organisations to cater for diversity and accommodate local solutions to local issues. The result is a more plural and diverse governing framework.

This research examines and documents the rise of what has been called community governance as governments seek to give more emphasis to the role of place in the design and implementation of policy solutions. Community governance, as defined in the research, is not understood as an alternative to the institutions of local government. Rather, it is seen as an augmented approach to, and style of, local government, which requires councils to consider the community's well-being and local outcomes in a collaborative manner, whether or not they have primary responsibility for the policies and services that contribute towards these outcomes. Councils that adopt a community governance role extend their activities beyond traditional service delivery roles in order to steer a multiplicity of public and private agencies and communities of interest towards common goals and policy settings.

The research topic was developed while I was a core research member of the Foundation for Research, Science and Technology (FRST) Local Futures Research Project, based at the School of Government, Victoria University. The project examined many aspects of strategic planning and policy, and, in particular, the role of councils in implementing the strategic planning and management provisions of the LGA 2002. The research topic offered a chance to develop a valuable international and local perspective on community governance, and my membership in the project facilitated access to councils 
and information, which was useful to the wider research agenda. The examination of community governance also reflected my professional interest as a Manager (Governance) for Local Government New Zealand (a national membership organisation for local governments) although 'governance' in my professional role should not be confused with the concept of 'community governance' as a more engaged form of local government. 


\section{Acknowledgements}

I wish to express thanks to members of the Foundation for Research, Science and Technology (FRST) Local Futures Research team for their encouragement and assistance, including my supervisor Professor Claudia Scott, co-supervisor Russell Harding, research colleague Jeff McNeill and project editor Janet Hughes. In addition, I wish to acknowledge the enthusiasm of, and encouragement given by, my colleagues at Local Government New Zealand, including Chrissy MacDonald, Mariska Wouters and especially my Chief Executive, Eugene Bowen. Finally I would like to recognise the patience and tolerance of my family, without whose support it would not have been possible. 


\section{Table of Contents}

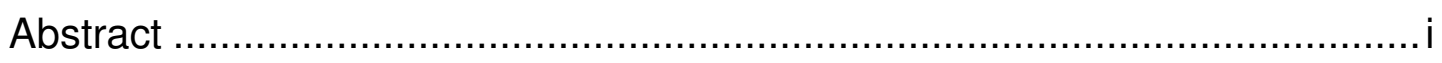

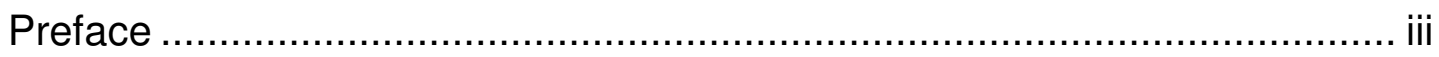

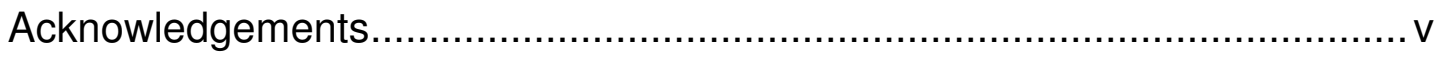

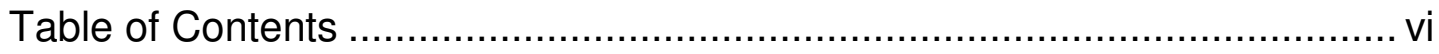

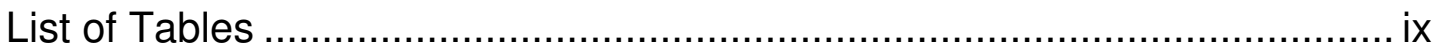

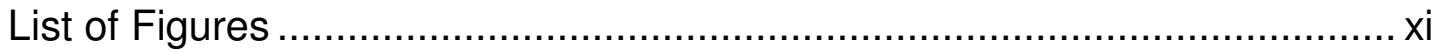

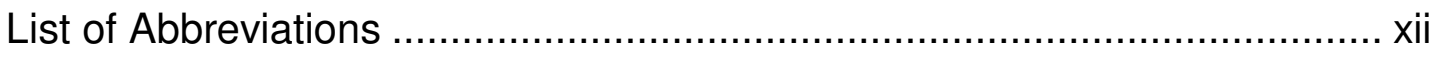

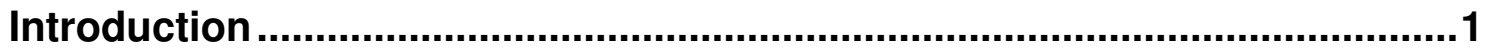

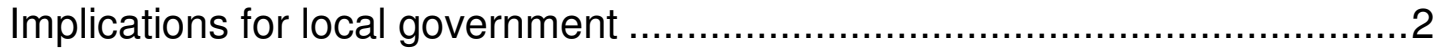

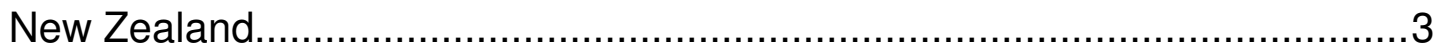

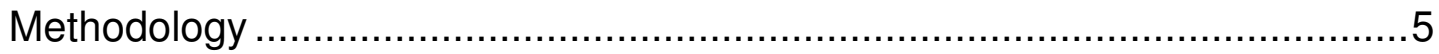

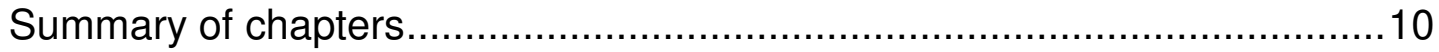

Chapter 1 The New Zealand approach to local government ...................13

Auckland: a new focus on metropolitan governance...................................14

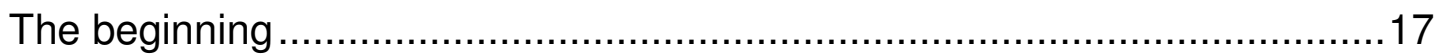

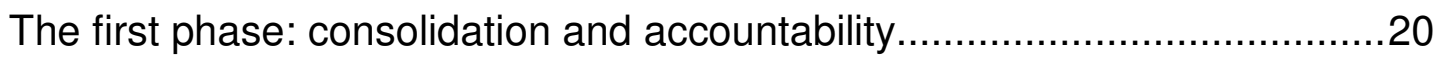

The second phase: financial management ..............................................26

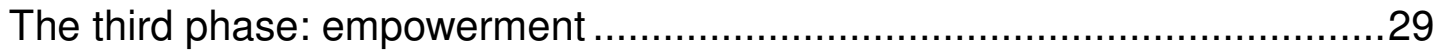

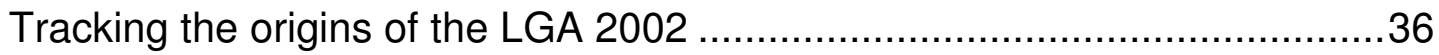

Redefining the concept of local government............................................ 40

The impact of reform on intergovernmental relationships ...........................55

The Auckland governance report - the outcome ………………................66

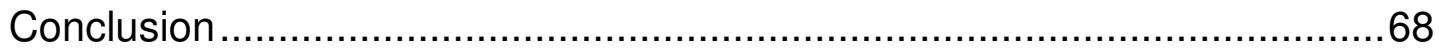

Chapter 2 Community governance theory.................................................72

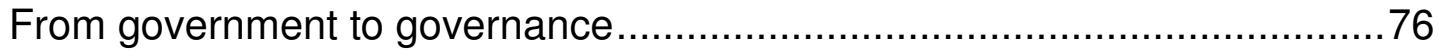

Community governance ............................................................................

The literature on local government and community governance ..................89

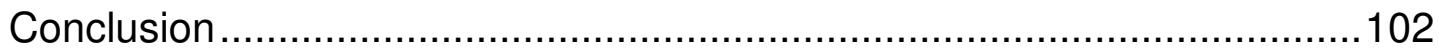

Chapter 3 Community governance principles........................................104

Principles: local government and community governance .........................107

Developing an assessment model .....................................................114

The local governance assessment model............................................119 
Conclusion 120

Chapter 4 The role of local government...............................................122

Economic theories of local government ...................................................123

Political theories of local government ...................................................127

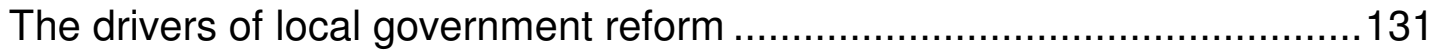

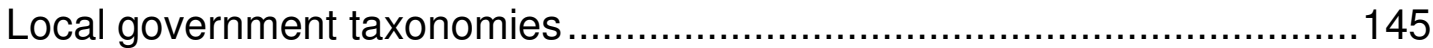

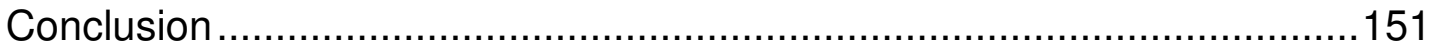

Chapter 5 Community planning and governance ................................153

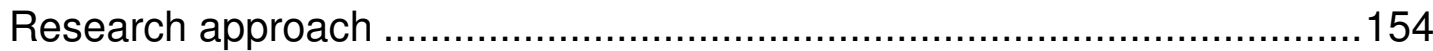

Community planning: the process.......................................................157

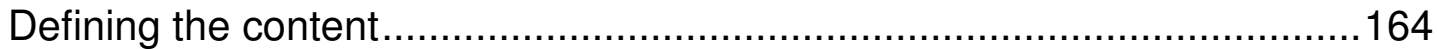

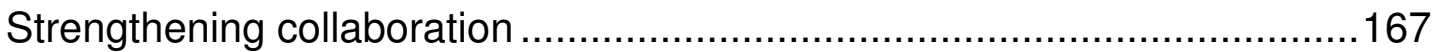

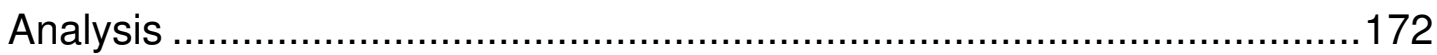

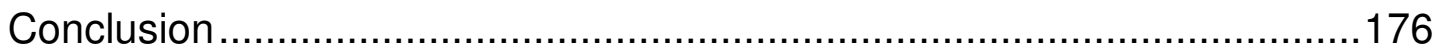

Chapter 6 Governance scenarios: testing opinion ..............................178

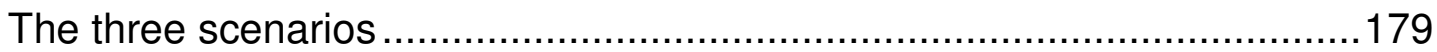

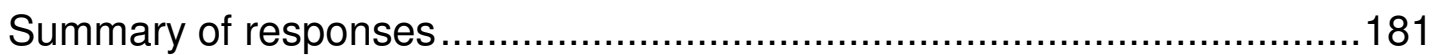

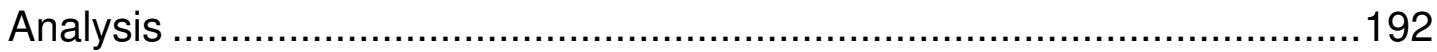

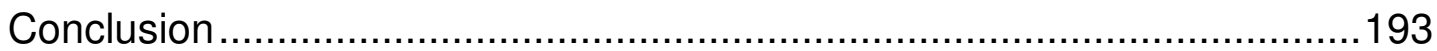

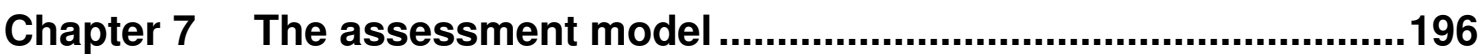

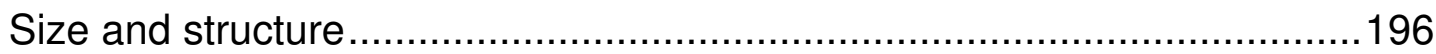

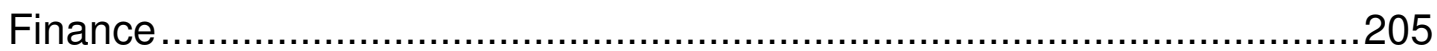

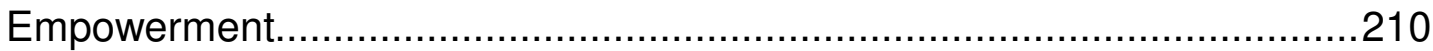

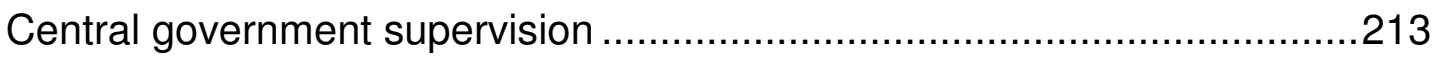

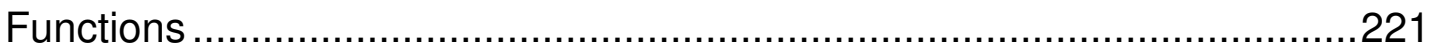

Strategy

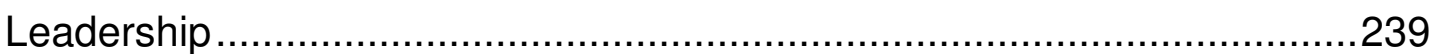

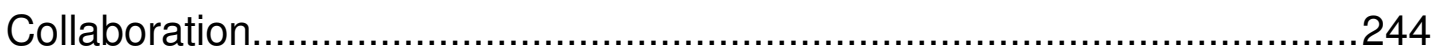

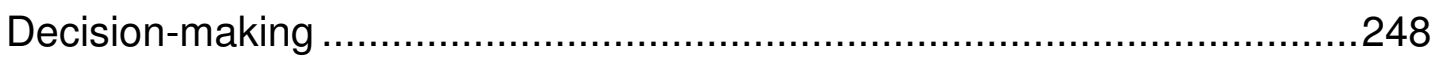

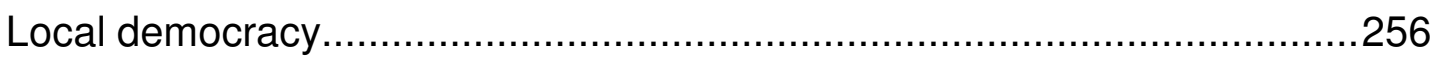

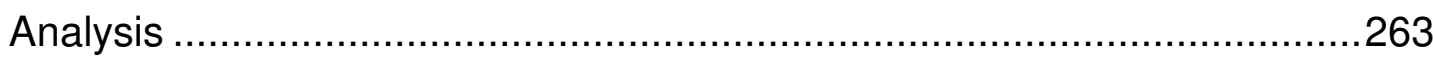

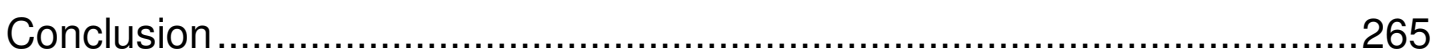

Chapter 8 Pathways to stronger community governance .....................267

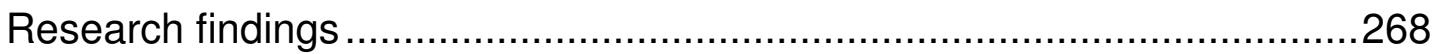

Options for strengthening community governance...................................272 


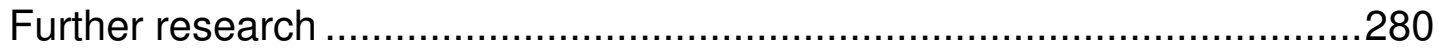

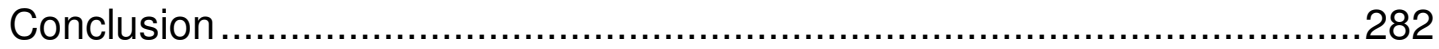

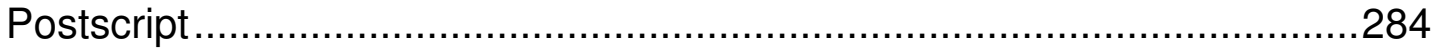

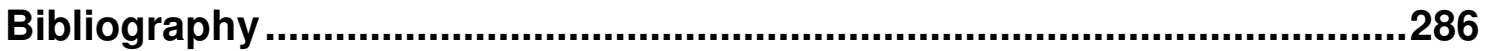

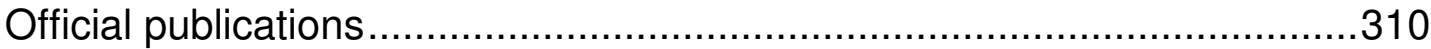

Appendix 1: List of New Zealand local authorities .................................315

Appendix 2: $\quad$ Map of local government boundaries ................................317

Appendix 3: The Royal Commission on Auckland Governance ............319

Appendix 4: Questionnaire.......................................................................322 


\section{List of Tables}

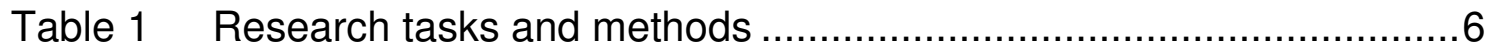

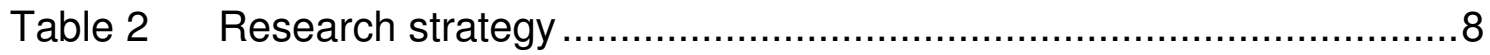

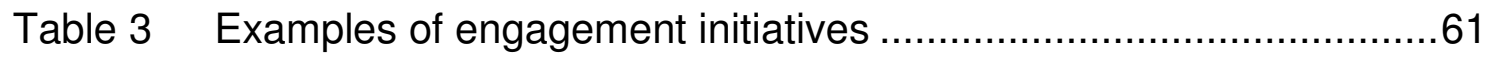

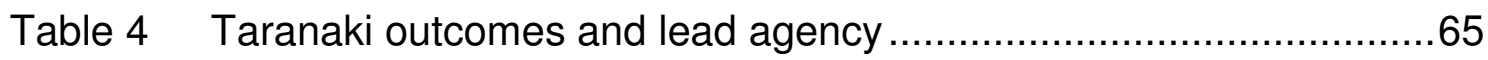

Table 5 The story of local government reform..........................................69

Table 6 Summarising governance theory ..............................................73

Table 7 Characteristics of government and governance .............................79

Table 8 From local government to community governance ........................87

Table 9 Key attributes of local governance theories ................................101

Table 10 Principles of effective local government ......................................107

Table 11 Characteristics of local government and community governance 110

Table 12 Central government steering mechanisms ..................................144

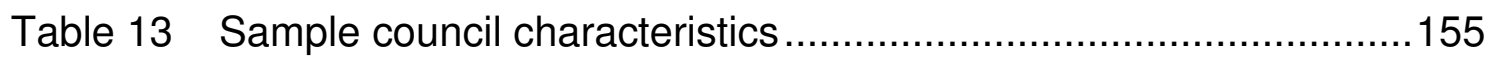

Table 14 Sample population as proportion of total population ....................156

Table 15 What the auditors were looking for............................................162

Table 16 Tomorrow's Manukau themes.................................................165

Table 17 Waitakere City Council outcome headings..................................166

Table 18 Analysis of community outcomes practice .................................173

Table 19 Stylised governance models .....................................................180

Table 20 Average council size by country .................................................199

Table 21 Local government structures ..................................................202

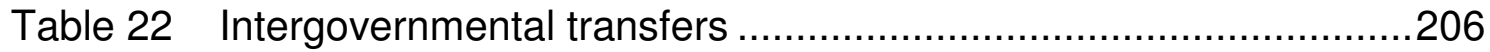

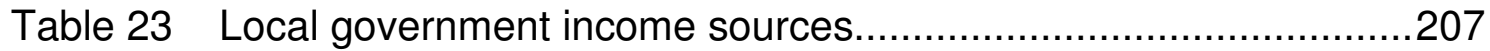

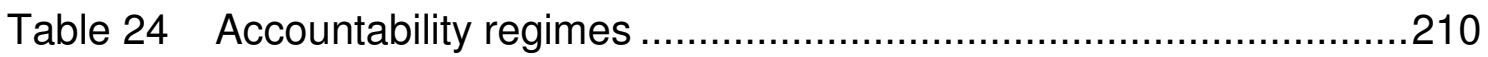

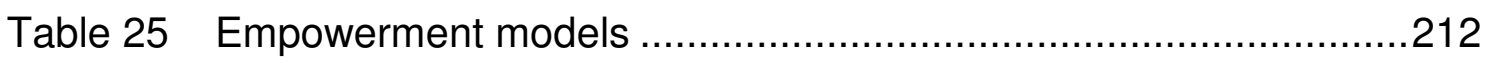

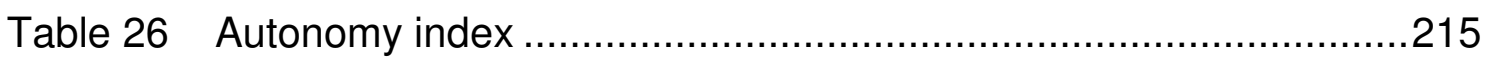

Table 27 Local government supervision .............................................219

Table 28 Local government expenditure ..............................................222

Table 29 Analysis of local government functions ....................................225

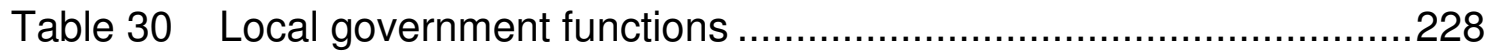

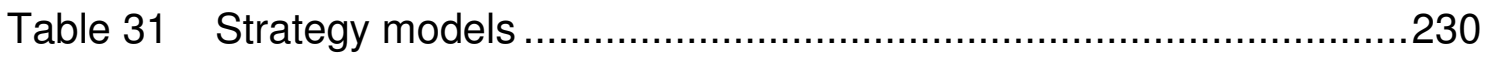




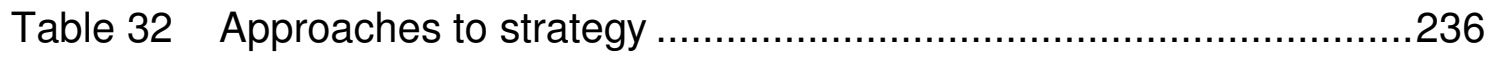

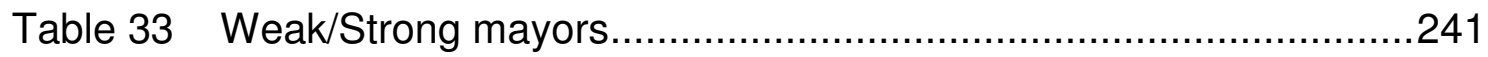

Table 34 Average number of submissions received by councils.................253

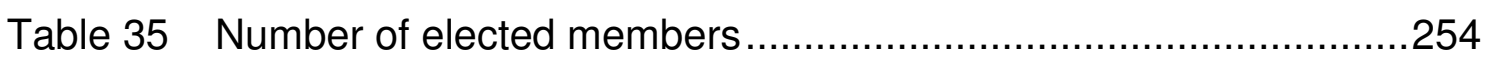

Table 36 Local government voter turnout (post 1995) ..............................258

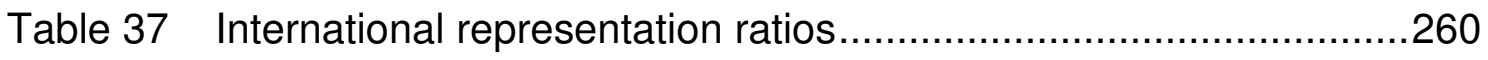

Table 38 Representation ratio in New Zealand local government................261

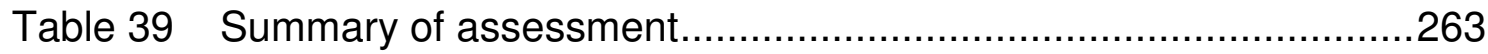

Table 40 Functions suitable for devolution..............................................273 


\section{List of Figures}

Figure 1 Long Term Council Community Planning framework ......................49

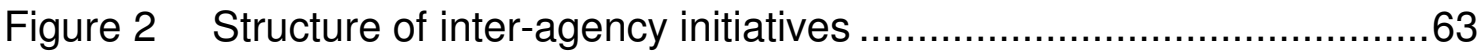

Figure 3 A family of community governance theories................................90

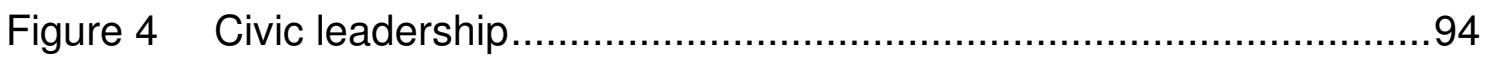

Figure 5 Local governance assessment model.......................................119

Figure 6 Council expenditure by head of population ................................141

Figure 7 Marlborough's outcome planning framework ..............................161

Figure 8 Dunedin: collaborating for outcomes.........................................168

Figure 9 Number of councils by population ..........................................198

Figure 10 Task profile selected cities ....................................................227

Figure 11 The United Kingdom's strategic framework ................................235

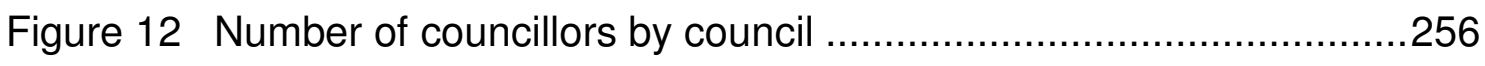

Figure 13 Average voter turnout 1989-2007 .........................................257 


\section{List of Abbreviations}

$\begin{array}{ll}\text { ARC } & \text { Auckland Regional Council } \\ \text { CCO } & \text { Council Controlled Organisation } \\ \text { CCTO } & \text { Council Controlled Trading Organisation } \\ \text { CGIG } & \text { Central Government Inter-Agency Group } \\ \text { CLGF } & \text { Commonwealth Local Government Forum } \\ \text { CLOGS } & \text { Central and Local Officials Group on Sustainability } \\ \text { CO } & \text { Community Outcomes } \\ \text { COBOP } & \text { Community Outcomes Bay of Plenty } \\ \text { DELG } & \text { Department of Environment and Local Government } \\ \text { DIA } & \text { Department of Internal Affairs } \\ \text { DOC } & \text { Department of Conservation } \\ \text { DPMC } & \text { Department of the Prime Minister and Cabinet } \\ \text { EDA } & \text { Economic Development Agency } \\ \text { FPP } & \text { First Past the Post } \\ \text { JUG } & \text { joined-up government } \\ \text { KRA } & \text { Key Result Area } \\ \text { LA21 } & \text { Local Agenda 21 } \\ \text { LAA } & \text { Local Area Agreement } \\ \text { LGA 1974 } & \text { Local Government Act 1974 } \\ \text { LGA 2002 } & \text { Local Government Act 2002 } \\ \text { LGAA3 } & \text { Local Government Act Amendment Act (No. 3) } \\ \text { LGNZ } & \text { Local Government New Zealand } \\ \text { LGRA } & \text { Local Government (Rating) Act 2002 } \\ \text { LMC } & \text { Labour Market Councils } \\ \text { LSP } & \text { Local Strategic Partnership } \\ \text { LTCCP } & \text { Long Term Council Community Plan } \\ \text { LTFS } & \text { Long Term Financial Strategy } \\ \text { MED } & \text { Ministry of Economic Development } \\ \text { MMP } & \text { Mixed Member Proportional } \\ \text { MSD } & \text { Ministry of Social Development } \\ \text { NLGN } & \text { New Local Government Network } \\ & \end{array}$




$\begin{array}{ll}\text { NPM } & \text { New Public Management } \\ \text { OAG } & \text { Office of the Controller and Auditor-General } \\ \text { OECD } & \text { Organisation for Economic Cooperation and Development } \\ \text { ORC } & \text { Otago Regional Council } \\ \text { POA } & \text { Programme of Action } \\ \text { RC } & \text { Regional Council } \\ \text { SCA } & \text { Sustainable Communities Act 2007 } \\ \text { SCP } & \text { Special Consultative Process } \\ \text { SOI } & \text { Statement of Intent } \\ \text { SOLGM } & \text { Society of Local Government Managers } \\ \text { SRA } & \text { Strategic Result Area } \\ \text { SSC } & \text { State Services Commission } \\ \text { STV } & \text { Single Transferable Vote } \\ \text { UNDP } & \text { United Nations Development Programme } \\ \text { TA } & \text { Territorial Authority } \\ \text { TRC } & \text { Taranaki Regional Council } \\ \text { UTS } & \text { University of Technology Sydney } \\ \text { WZB } & \text { Wissenschaftszentrum Berlin }\end{array}$




\section{Introduction}

Governance, in the broad sense of how we govern ourselves, is a topic that has concerned citizens and those who write about citizens since humans first began to form groups and confronted issues regarding the distribution of power. The question of how society should govern itself and make collective decisions is as relevant and complex today as it was more than 2,000 years ago when Plato turned his mind to the issue. While governance deals with universal matters, such as the distribution of power and authority, the interpretation of the term is always contingent on socio-economic contexts, varying according to culture, tradition and circumstances. The Roman Republic, for example, used multiple governance models, depending on whether the city was at peace or war; when it was at war, the rule of the senate was temporarily suspended, and was replaced by two governors with temporary dictatorial powers.

Debates about governance are concerned with the issue of power and, today, are often about its distribution across government units at local, regional, national and international levels. It is not surprising, therefore, that at times of rapid social, cultural, economic and environmental change (such as experienced in the latter years of the 20th century) new institutional arrangements for collective decision-making are attracting interest. Policy challenges, resulting from climate change, globalisation, growing diversity and 'wicked issues' (Roberts 2000), have often proved beyond the capacity and capability of a single government to address in isolation. When this happens, a loss of confidence in current governance arrangements may occur, including a sense that centres of power are outside citizens' control. The result has been a democratic deficit (Giddens 2000) and a loss of legitimacy. ${ }^{1}$ In addition, citizens' expectations of governments have changed as the post-war welfare state has given way to a more market-led approach to governance. Rhodes (1997) describes this phenomenon as a differentiated polity, a public sphere which is by nature highly fragmented. New forms of governance are emerging at

\footnotetext{
${ }^{1}$ According to the Social Attitudes survey, conducted annually in the United Kingdom, the percentage of people voting as a civic duty has fallen from 76 per cent in 1987 to 56 per cent in 2009 (The Economist, 30 January 2010, p. 63).
} 
international and national levels and also at the local level. However, the reason for change is contested.

For example, some commentators regard the new forms of plural democracy as related to the growth of networks that emerged in the face of the limitations of hierarchies and markets to address contemporary issues (see Stewart \& Clarke 1996, Rhodes 1997, Albrow 2001). A related perspective is that sovereignty has leaked down to regional and local governments (due to the state devolving responsibilities to sub-national administrations) in response to a desire to enhance the quality of governance or address more immediate fiscal considerations, such as national budget deficits (Bryson 2004, Oates 1999). Also agreeing that traditional models of governance have under-performed, writers such as Osborne and Gaebler (1992) explain the changes as a shift to a more entrepreneurial form of government which places more emphasis on outcomes as opposed to outputs. Other points of view argue that the reforms can be explained less by the desire to make government more effective than by a range of political and economic factors, such as a loss of legitimacy (Andrew and Goldsmith 1998), the triumph of 'neo-liberalism' (Kelsey 1994, Mishra 1999, Klein 2001) or simply the vulnerability of governments to capture by interest groups (Kerr 2003).

\section{Implications for local government}

Regardless of these various interpretations, and of whether change is positive or negative, what is clear is that the governance environment is changing and has implications for the future role and status of local government. Rhodes (1997) describes a 'hollowing out' of government, whereby policy and operational responsibilities have shifted vertically and horizontally. Vertically, the shift has been to pan-national organisations in order to regulate global capital, as well as sub-national governments to meet demand for greater autonomy. Horizontally, the shift has been to quangos in order to deliver arm'slength services, free from political interference. The effect on government sovereignty of such vertical and horizontal transfers has been described as a process of denationalisation (Sassen 2006). 
This changing national context has led to a debate about the ultimate role and purpose of local government, including the suggestion that the prime business of councils is now "the guardianship of difference; the protection of future selves; the advancement of positive rights and the provision of civic leadership" (Reid 1994, p. 2). Many local governments have expanded their role from an exclusive concern with the effective and efficient management of services to a new focus on community-wide outcomes, a phenomenon which has been described as a move from local government to community governance. Community governance is a term coined to describe a trend in the way local governments are beginning to operate, such as breaking down the bureaucratic and organisational boundaries between councils and their communities, and facilitating collaborative strategies for the achievement of local outcomes.

\section{New Zealand}

In New Zealand the debate about the role and potential of local government has centred on changes to the sector's empowering legislation. The most recent iteration, the Local Government Act 2002 (LGA 2002), is possibly the most comprehensive change to local government since the consolidation of local authorities in 1988/89. It is widely regarded as introducing a new paradigm of local government in New Zealand (McKinlay 2004, Thomas and Memon 2005, Cheyne 2008), although debate continues as to the truth of such claims. The question of whether the LGA 2002 represents simply a logical 'next step' in the reform process or represents a decisive break with tradition which has steered local government in a radical new direction (see Kerr 2003) is yet to be resolved.

The New Zealand style of local government is something of an outlier by international standards, its Australian counterpart being perhaps the most similar. Established in the middle of the 19th century to meet the needs of a rapidly growing settler population, local government was necessary to build local and national infrastructure and provide communities with some capacity for self-government. New Zealand local government stands out for its high level 
of autonomy (90 per cent of its income is self-generated) and low 'task profile' (the small number and extent of its mandatory functions). Because the major social services, such as health and education, are centralised, New Zealand local government's 3.1 per cent (2009) share of gross domestic product is low by international standards, as is its share of public expenditure at less than 10 per cent.

The LGA 2002 was a major revision of New Zealand local government's empowering statute, introducing changes to its powers, purpose, processes and decision-making principles, without, however, significantly altering its funding or task profile. A debate arose as to whether the legislation was simply a modernisation of local government's powers and purpose, or a new mandate for a form of community governance; "the community governance mandate in the LGA has opened a window of opportunity for community engagement and intergovernmental collaboration to an extent that has not been witnessed before in New Zealand" (Leonard and Memon 2008, p. 44).

Leonard and Memon observe strong connections between the New Zealand reforms and international change, particularly in the United Kingdom. Some commentators (Cheyne 2008, McKinlay 2004) have also drawn parallels between the new legislation and the Local Government Act 2000 in the United Kingdom, particularly in the focus on community planning and the promotion of well-being. Leonard and Memon (2008), noting the Act's stronger emphasis on participation and civic engagement, suggest local reformers were influenced by the rise of a Third-Way discourse (which promoted a style of governing that drew on both markets and hierarchies in contrast to previous models which strongly favoured one or the other).

Although it clearly reflects international influences, the LGA 2002 has been regarded internationally as highly innovative and cutting edge, particularly in its emphasis on sustainability and community outcomes. This raises interesting questions, for example, whether the Act's emphasis on sustainability, well-being and community outcomes is reflective of reforms in other countries or is uniquely a 'down under' feature. The New Zealand reforms may survive over 
time to provide guidance for similar reforms elsewhere; or the changes may be judged a 'wrong turn' on the basis that they fail to take root or are ideologically uncomfortable to future governments.

Because of its size and the speed of its parliamentary decision-making processes, New Zealand is sometimes regarded as a laboratory for new publicsector ideas. The country is often an early adopter of new policy approaches which can provide information and evidence to inform policy decisions in other countries. Examining the New Zealand approach to local government may help understand the factors that will lead to success or failure in the implementation of community governance. Thus, New Zealand's experiences may influence reforms in other systems.

\section{Methodology}

Designing a methodology to address the research questions involved the challenge of defining community governance, a term for which there is no precise or widely accepted definition. The challenges included the difficulty of measuring changes under dynamic frameworks subject to frequent statutory and regulatory adjustment, and determining the extent to which they can be attributed to the influence of the legislation. In addition, the term 'community governance' is seldom used in public discourse in New Zealand. This raises the possibility that efforts to determine the opinion of local government professionals on this topic may be frustrated by their limited understanding of the concept.

To resolve this issue the literature concerning community governance has been reviewed and certain core principles isolated - the principles providing the basis for the development of an assessment model. The assessment model (see Chapter 4) is based on the community governance literature. In order to complement this with some 'on the ground' research, two other research methods were chosen. One involved a questionnaire of selected local government personnel (elected members, officials and policy adviser employed by Local Government New Zealand (LGNZ)) to 'test' three different governance 
scenarios. Information from this exercise has been used in the discussion of the size and structure dimension in Chapter 7. Participants in the research were provided with a handout that introduced them to the theory and practice of community governance and were asked to read this before answering the predetermined questions on each of the scenarios (see Appendix 4 for a copy of the information sheet and questionnaire). In addition, an examination was undertaken into how a sample of councils undertook their community planning obligations as required by the LGA 2002. This was used to identify the degree to which councils saw community planning as a way of strengthening community governance.

\section{Research paradigm}

The focus of the research is strengthening community governance in New Zealand local government. It involves defining community governance, and making an assessment of its relative strength in the New Zealand system. Multiple research methods were employed to undertake an array of research tasks (see Table 1).

Table $1 \quad$ Research tasks and methods

\begin{tabular}{|l|l|}
\hline \multicolumn{1}{|c|}{ Research tasks } & \multicolumn{1}{c|}{ Methods } \\
\hline $\begin{array}{l}\text { Analysing the New Zealand local } \\
\text { government system and the direction } \\
\text { of recent reform }\end{array}$ & $\begin{array}{l}\text { Archival analysis } \\
\text { Literature review } \\
\text { Case studies } \\
\text { Assessment model (see below) }\end{array}$ \\
\hline $\begin{array}{l}\text { Describing the major schools of local } \\
\text { government theory }\end{array}$ & Literature review \\
\hline $\begin{array}{l}\text { Reviewing community governance } \\
\text { theory and defining the concept of } \\
\text { community governance as well as } \\
\text { describing its socio-historical context }\end{array}$ & Literature review \\
\hline $\begin{array}{l}\text { Developing a model of community } \\
\text { governance, with key principles and } \\
\text { indicators against which to assess the } \\
\text { New Zealand approach }\end{array}$ & \begin{tabular}{l} 
Aiterature review \\
\hline
\end{tabular} \\
\hline
\end{tabular}




\begin{tabular}{|c|c|}
\hline $\begin{array}{l}\text { Assessing aspects of the New } \\
\text { Zealand approach against the } \\
\text { principles of community governance }\end{array}$ & $\begin{array}{l}\text { Comparative analysis } \\
\text { Questionnaire } \\
\text { Case studies }\end{array}$ \\
\hline $\begin{array}{l}\text { Proposing options for strengthening } \\
\text { community governance in New } \\
\text { Zealand local government }\end{array}$ & Comparative analysis \\
\hline
\end{tabular}

Identifying options for strengthening community governance does not suit any single research paradigm. It is not simply a matter of collecting data, as 'strength' in this context involves subjective judgements and is being applied metaphorically to something that is abstract and not quantifiable. The research method used in this dissertation sits squarely in the realist paradigm, using several different techniques to provide cumulatively an appropriate rigour to the resolution of the research question. This research is primarily inductive in that general conclusions about strengthening community governance are intended to be based on evidence drawn from the case studies, the questionnaire and the assessment tool. Conclusions drawn from the information raised by the case studies, the questionnaire and the assessment model are subjective and reflect a constructivist approach, given that people tend to construct knowledge on the basis of their own experience. This was particularly true of the questionnaire and discussion groups as participants' replies were coloured by the type of council they represented. In one aspect it uses deductive logic, in that the principles of community governance are derived from an analysis of the existing theory pertaining to the concept and translated by the researcher.

When selecting research methods the topic presented a number of challenges. Community governance is a social construct. It is not measurable in any strict sense, and debate continues as to whether or not it reflects a distinct theory and model of local government or is simply a political style, for example the local government equivalent of the Third Way. Nor is there an accepted benchmark of community governance, so an assessment model of community governance needed to be developed from the literature. This approach, in which an actual system of local government is compared with a model, is only as sound as the 
information on which the model is based. The overall approach is summarised in Table 2.

\begin{tabular}{|l|l|}
\multicolumn{1}{c}{ Table 2 Research strategy } \\
\begin{tabular}{|l|l|}
\hline Research paradigm & Realism \\
\hline Research approach & Primarily inductive \\
\hline Research methods & Case study \\
\hline & Archival analysis \\
\hline & Literature review \\
\hline & Comparative analysis \\
\hline & Assessment model \\
\hline & Questionnaire \\
\hline
\end{tabular}
\end{tabular}

Several research methods were selected so the issue could be considered from more than one perspective. If two or more research methods suggest a similar conclusion, the overall conclusions are likely to be more reliable. The research methods include a review of literature to determine what constitutes community governance; a literature review of the major schools of local government theory to describe the New Zealand system; historical analysis of the origins of local government reform to identify what the major drivers were and whether these are consistent with community governance theory; comparative analysis of dimensions of the New Zealand system of local government; and case studies and a questionnaire.

It was felt that relying only on the assessment model would be too onedimensional and that some original research should also be used. The questionnaire was designed to seek feedback on different governance scenarios, with the emphasis on size and structure. It sought to seek the views of a range of invited participants who were not selected at random, the questionnaire results having no wider validity than representing the views of the participants. The second example of new research was the decision to base a chapter on the analysis of a sample of councils' community planning practice undertaken by Local Futures, a multi-disciplinary team undertaking a longitudinal study of strategic planning in local government. These case studies 
are based on interviews with council staff and indicate the different approaches councils have taken to community planning, an important component of community governance. The key components of the research are as follows:

- case studies of community strategic planning, as introduced by the LGA 2002, to explore the degree to which councils see this mechanism as a way of achieving community governance or regard it as simply another expensive central government obligation

- a questionnaire, answered by invited local government practitioners, to elicit their views and opinions about the ability of different governance scenarios to achieve community governance. Participants were also invited to elaborate on their answers in a series of discussion groups

- a model of community governance, developed to assess the ability of the New Zealand local government system to achieve community governance. The model incorporates commonly agreed principles of community governance disaggregated into 10 distinct dimensions. Each dimension is assessed as being either adequate or needing room for improvement.

The case studies and questionnaire both highlighted opportunities and provided information about the current ability of local government to adopt a community governance approach. The question of which parts of the system need attention in order to strengthen community governance is not directly addressed in those chapters and is the focus of Chapter 7 . This challenge involved designing a research method, the assessment model that examines the system against the principles of community governance in order to find which aspects or dimensions need to be enhanced if the principles are to be realised.

The assessment model examines the New Zealand system of local government by breaking it down into 10 dimensions, such as finance, functions and democracy, and uses measures which have been identified for each dimension to allow judgements to be made about the relative strength or weakness of each dimension in the context of relevant community governance principles. These are defined in Chapter 3. Working with 10 qualitatively different dimensions 
posed a methodological challenge as no particular analytic technique worked for all dimensions. Some measures were quantitative and allowed international comparisons; others were largely discursive, in which the New Zealand experience was discussed in relation to accepted theory, and shortfalls or synergies noted. Assessment in relation to these dimensions was qualitative and reflected the judgement of the writer. The model has been designed to inform the concluding chapter and ensure that strengthening proposals will address the most problematic dimensions.

\section{Summary of chapters}

\section{Introduction}

This chapter defines the topic of the research. It gives the reason for selecting the topic, and briefly notes pertinent trends. The LGA 2002 is introduced, along with some basic features of the New Zealand local government system. The methodology to be used and the content of the remaining chapters are outlined.

\section{Chapter 1 The New Zealand approach to local government}

This chapter examines the New Zealand local government system, looking in particular at its historical development and recent reforms. Emphasis is placed on the changes introduced by the LGA 2002 and their relationship to community governance.

\section{Chapter 2 Community governance theory}

This chapter explains the concept of community governance. It defines governance and community governance and discusses the concepts as they are used in the academic literature. The recent history of the terms is recounted and the relationship between community governance and local government analysed.

\section{Chapter 3 Community governance principles}

This chapter builds on the theory introduced in the previous chapter. It develops a series of 'community governance principles' and designs a model for 
assessing the capability of the New Zealand system to achieve a community governance approach.

\section{Chapter 4 The role of local government}

This chapter discusses theories and frameworks of local government, including recent international trends regarding local government reform and community governance. It also examines a range of meta-trends which are used to explain the recent growth of interest in 'governance' and local government.

\section{Chapter 5 Community planning and governance}

This chapter summarises and analyses research undertaken of a sample of local authorities' approaches to community planning. It concludes with an assessment to distinguish those councils which approach community planning as primarily a compliance requirement (and interpret the legislation in a minimalist manner), and those which regard it as proving a mechanism for achieving enhanced community governance.

\section{Chapter 6 Governance scenarios: testing opinion}

This chapter describes and then analyses the responses received to a questionnaire that sought feedback on three alternative governance scenarios. It concludes with a discussion about whether or not one of the scenarios is better placed to achieve community governance than the others. The conclusions of this exercise contribute to the discussion on the size and structure dimension in Chapter 7.

\section{Chapter 7 The assessment model}

This chapter applies the assessment model developed in Chapter 4. It analyses each of the dimensions identified in the model by reference to specific measures. The dimensions are assessed as being either adequate or showing room for improvement in relation to their ability to achieve a community governance approach. 


\section{Chapter 8 Final chapter}

This chapter summarises the research findings and proposes options for strengthening the ability of the New Zealand system of local government to adopt a community governance approach. Areas for further research are identified. 


\section{Chapter 1 The New Zealand approach to local government}

This chapter examines the New Zealand local government system, with emphasis on its historical development and recent reforms. It pays particular attention to the LGA 2002 and the degree to which changes introduced by that legislation have 'set the scene' for a model of community governance.

On 25 March 2009, the Royal Commission on Auckland Governance presented the Governor-General, the Hon. Anand Satyanand, with its recommendations for the future governance of Auckland. ${ }^{2}$ A day later the commission met with the Minister of Local Government and the Prime Minister and provided a briefing which covered the main points of their nearly 800-page report. It was perhaps the most significant event in the recent history of local government in New Zealand and dominated the country's media for days. Media interest was not fuelled simply by the prospect of change in the way in which Auckland might be governed but also by the radical nature of the commission's recommendations. The commission had offered the Government an innovative model of local government, one that differed radically from the approach to local government taken since the dissolution of the provinces more than 130 years previously. Within days the Prime Minister, the Rt. Hon. John Key, reconfirmed his government's intention to address the 'problem' of Auckland in time for the 2010 local government elections and he asked his Minister of Local Government, the Hon. Rodney Hide, to prepare recommendations for consideration at the next cabinet meeting. These were to be recommendations that would not only take the commission's proposals forward but would also address popular concerns about the potential loss of representation and community engagement contained in those proposals.

\footnotetext{
2 The Royal Commission's website, www.royalcommission.govt.nz, contains not only the final report but also copies of the commissioned research papers and analysis of submissions.
} 


\section{Auckland: a new focus on metropolitan governance}

Before the release of the report there was much speculation about whether the commission's recommendations would be for one large city, on the model of Brisbane; for a mix of territorial authorities with a Lord Mayor responsible for strategic services, similar to the London Authority; or for something more like Vancouver, which has a plurality of local governing arrangements operating alongside a separate authority that undertakes metropolitan functions. Subsidiary questions concerned the future of community boards and local democracy, the appropriate models for running metropolitan utilities, and the appropriate borders for the new authority. In the event, the commission went for a model of governance that was something of a mixture of international models. Consistent with Brisbane, it proposed consolidation and the creation of a large unitary council. From London it drew on the idea of a stronger mayor. The idea of six subsidiary local councils was largely a unique local suggestion (although sub-municipal bodies are relatively common around the world. There is nothing quite like the model proposed). ${ }^{3}$

The goal of consolidating eight separate local authorities and creating a single council was radical in its own right; however, the commission's recommendations on the interface between the new council and central government and their proposals for a more local approach to social and economic policy signalled a qualitatively different approach to conventional local government. As the commission noted:

Effective regional leadership and strategic decision-making by local government are required ... Achieving this will require the involvement of the multiplicity of stakeholders with an interest in the city's success and must be done in active partnership with central government. Local government institutions must be capable of bringing together different

\footnotetext{
${ }^{3}$ Brisbane is not a unitary authority, and some of the functions that will be carried out by the new Auckland City (assuming it is implemented as recommended) are undertaken by the State of Queensland.
} 
points of view, reaching agreement and ensuring that the resulting decisions are implemented (Royal Commission on Auckland Governance 2008, p. 58).

It was the nature of some of the commission's recommendations that suggest a qualitatively different model of local government, one that puts more emphasis on place and governance at the local level.

\section{Key recommendations}

A number of the commission's proposals were directly relevant, namely, the proposal for a more 'joined-up' approach to the provision of local services and an emphasis on 'partnership', which were intended to give Aucklanders a greater say in the planning and delivery of central government services in their city (for a summary of the commission's findings see Appendix 3 ). That this was a new approach was particularly signalled in the commission's recommendations that a partnership be developed between central government and Auckland's local government to address long-term economic development. It was recommended that the new council include a vision for the region in its spatial plan, and that the mayor be required to make a 'state of the region' address annually, describing progress towards the vision. Other recommendations also reflected a new approach to local governance:

- the establishment of a high level, regional, cross-sectoral advisory board (social issues board) comprising representatives of central government, local councils, business, education and not-for-profit organisations

- the development, by the social issues board, of a social well-being strategy and implementation/funding plan, as well as the establishment of a joint officials group

- that the Auckland City council focus on providing leadership and facilitating better social well-being and other well-being outcomes

- that the Government consider aligning the geographical boundaries of local government and central government agencies responsible for the delivery of social services. 
The commission also recommended that the Government appoint a senior minister as Minister for Auckland and establish an Auckland-specific Cabinet Committee. ${ }^{4}$ This committee would set priorities for government spending in Auckland and the Minister for Auckland would convene an annual forum, consisting of the Auckland Council and relevant interest groups, to provide feedback. The commission's report signalled a different model of local government, one which would be explicitly concerned with bringing together the different agencies concerned with the governance of Auckland, particularly in the economic and social areas. The report, regardless of the Government's response, marked an important stage in the development of local government in New Zealand, as it indicated that ideas about the role and purpose of local government had changed fundamentally. Its publication highlights an increasing interest in the role of local government in achieving national goals while also stressing the importance of greater engagement with citizens; and many of the recommendations, while radical in the New Zealand context, reflected developments that had already occurred in local government systems in other countries. Ultimately they represent a different way of thinking about the role and character of local government, one that extends beyond the boundaries of institutions to focus on the overall well-being of particular places. It is a model indebted to the idea of government as a form of governance and in particular community governance. The pressing question, however, is whether the Royal Commission's view of local government, as a progressive contributor to community well-being, indicates a shift in public and official thinking about the role of local government. And if it does, can we take this as indicative of the sector's likely future, especially the nature of future local government reform? To answer these questions it is necessary to go back to the start of the modern reform period.

\footnotetext{
${ }^{4}$ Early indications are that the suggestion of a specific Minister for Auckland and cabinet committee will not be actioned. In an interview with TV1 news, 7.05 am Monday 30 March 2009, the Prime Minister indicated a lack of support for these proposals and stated that he believed all his ministers should be sensitive to Auckland concerns.
} 


\section{The beginning}

The period since the late 1980s has been one of unprecedented change in New Zealand local government, which left little of the sector untouched. This flurry of legislative activity was intended to improve efficiency, accountability and responsiveness to citizens (Bush 1995, Bassett 1996, Reid 2002, Boston et al 1996). While it is broadly agreed that local government reform paralleled public sector modernisation (Kelsey 1994, Boston et al 1996), it has some features unique to local government, particularly the desire to give citizens more say in the decisions made by their councils. It further diverged from the general direction of state sector reform, which favoured the formation of single-purpose agencies; in its preference for aggregating independent single-purpose bodies (see Appendix 1 for a list of local authorities and their populations). This chapter examines the three major periods of reform since 1989 and considers the degree to which community governance has been strengthened or weakened by this process.

To understand the nature of the local government model that has emerged through this reform process, and the ideas underpinning the design, it is useful to consider the historical circumstances that shaped the sector's development, and in particular the way which a tension between two distinct conceptions of local government has played out over time. According to one conception, local government is simply a form of local administration delivering a discrete set of services, which are local public goods (Kerr 2003). The other conception treats local government as government in the broader sense, providing members of communities with an institutional framework to make decisions about their collective future, in other words a local polity (Reid 1994, Richardson 1999a).These two concepts set the boundaries within which local government policy has fluctuated over the last two decades.

For most of its history, local government in New Zealand has operated with considerable autonomy and minimal engagement with the centre. Much of this can be explained by the incremental way in which the sector began, with 
communities forming and seeking to control aspects of their environments; the result was a culture of strong localism characterised by a sense of collective self-help. The creation of multiple elected bodies by which citizens sought to manage local affairs set the scene for more than a century of reform efforts as central government sought (mostly unsuccessfully) to create more effective local government units with a capacity to provide a wider range of functions and public services.

In the beginning, local government began with the imposition of British rule following the signing of the Treaty of Waitangi in 1840. The establishment of a network of councils with distinct responsibilities and fund-raising powers took some time. The Colonial Office in London was keen to replicate the local administrations that had emerged in the home country in its new colonies in the South Pacific, and instructed British governors to "divide the land into districts, counties, towns and townships and parishes and to promote the establishment of local bodies to oversee such matters as drainage" (Bush 1995, p. 11). Early governors, however, were not enthusiastic, citing the small number of settlers and the cost of such institutions, and eventually settled on a form of provincial government. However, in the late 1860s a consistent form of borough and county government began to emerge, effectively signalling the end of the provinces, which were officially disbanded in the mid 1870s. The 1867 Municipal Corporations Act, for example, was the first substantial attempt at urban governance and provided the first comprehensive framework for governing the growing urban centres.

\section{Multiplication}

Despite this reluctant start, within 10 years of the passage of the Municipal Corporations Act there had been substantial growth in the number of elected forms of local governance, particularly single-purpose boards, such as road boards and pest destruction boards. Indeed the nature of the institutional framework encouraged fragmentation, with the formation of new councils being accelerated by the existence of government start-up grants for each new authority (encouraging existing authorities to subdivide in order to receive the grants). As a result, attempts at consolidation by the state began as early as 
1875 , but met with little success in the face of local opposition, leaving a local government sector in a state of "variegated fragmentation" as "provincial powers (were) handed to lilliputian local authorities with the centre assuming responsibility for the very minimum" (Bush 1995, p. 20). The extreme fragmentation of the sector may explain the reluctance of Parliament over the last century to entrust local government with more substantial policy and operational responsibilities, resulting in the highly centralised state that currently exists, particularly since the introduction of the welfare state.

The failure of the governments to establish a framework for limiting the growth of local governments - itself a testimony to the strength of localism - persisted until at least the 1930s. By the end of the 19th century, the number of locally elected bodies, ranging from borough and county councils to pest destruction boards, had mushroomed to 552 (and would continue to grow). Grand plans to reform the sector by reducing the number of councils in order to achieve economies of scale and scope became common. The governments of both Seddon, in the mid 1890s, and Ward, a decade or so later, promoted major reform plans but neither secured the support of Parliament. Their lack of success has been partly explained by local government's narrow task profile, with Easton noting: "the functions of local government were so limited relative to central government that there was little to be gained from a more rational structure" (Easton quoted in Dollery and Wallis 2001b, p. 202). "Little to be gained" euphemistically describes the feeling that there were few advantages to be gained by driving comprehensive reform, given the political pain likely to be created by local opposition. Consequently, governments were reluctant to devolve major responsibilities, such as hospitals, policing, or social security, to local government and progressively centralised functions regarded as nationally significant. Bassett explains this by suggesting that "it is very unlikely that a local authority that is so small that 10 percentage of its total income goes on the town clerk's salary alone ... can do much for its constituents; however, inspired the mayor and councillors" (Bassett 1996, p. 30).

It is perhaps time to re-examine the conventional wisdom, by which localism is regarded as a problem that delayed the introduction of a more 'rational' form of 
local government, particularly given the new recognition of place in governing (see Lyons 2007). The resistance to consolidation and national government intervention, which lasted at least until the introduction of the welfare state (and is currently found in the opposition of some rural communities at being combined with the new Auckland Council), should be seen as more than simply a form of reactionary parochialism. The growing appreciation of the value of localness has resulted in a new understanding of local government as a mechanism for the expression of community preferences, rather than a form of local administration delivering services on behalf of the centre. While it was inevitable that the state would ultimately triumph in achieving its reform objectives, given that it was seen as being in the national interest, consolidation took until the election of the fourth Labour Government in 1984 to begin in earnest. This was the first of three major reform phases.

\section{The first phase: consolidation and accountability}

The first phase was dominated by the decision to undertake a comprehensive programme of consolidation. On coming into office in 1984 the new Labour Government found itself forced to confront a number of major policy issues that concerned the fundamental character of the public sector and many of its macro-economic policy settings. Not only did it have an excuse to examine the way in which the public sector worked, it also had the parliamentary majority that enabled it to carry through such a mandate.

The reform of local government was undertaken in the government's second term and resulted from a coincidence of the presence of policy entrepreneurs and the opening of a policy window (Dollery and Wallis 2001a). The entrepreneurs, in this case the Minister of Local Government, the Hon. Michael Bassett, and the Chair of the Local Government Commission, Sir Brian Elwood, began preparing the ground for reform in the first two years of the Government's first term. However, the policy window was not created until the decision by the Government, in its second term, to undertake a broad reform of public management - a move also partly driven by the impact of the 1987 sharemarket crash. 
There was also pressure from the community as post-war growth in civic participation and activism spread to New Zealand. The apparent political consensus of the 1950s and 1960s began to erode in the face of communitybased political campaigns that expressed opposition to particular government policy and decisions. Examples included the Save Manapouri campaign (against a hydro-electric development with severe ecological effects), the Vietnam War, and sporting relations with South Africa. All signalled a resistance to particular policies adopted by successive governments that appeared to be more responsive to the objectives of their key partners, business, farming and organised labour organisations, than the needs of citizens.

The design of the local government system that emerged out of this period of reform also reflected a growing disenchantment with the New Zealand governance model in general, a highly centralised state with a 'winner takes all' form of representation. For much of the century the New Zealand form of governance was a corporate form of capitalism in which the farming, business and labour elites would meet regularly and hammer out a mutually acceptable version of the good life - a system unlikely to meet the diverse needs of an increasingly pluralist society. It was not a surprise that the new style of local government that emerged after 1989 reflected concerns about governments that were distant and unresponsive. With its mandatory consultation requirements, including the preparation of public annual plans and budgets, as well as new neighbourhood-type political structures (community boards), the new local governments were required to pay a lot more attention to the needs and preferences of their citizens, including political participation. ${ }^{5}$

\section{The recipe for change}

The reform of local government took two distinct but related forms, the rationalisation of local government numbers and the introduction of more

\footnotetext{
${ }^{5}$ In the Statement on Reform of Local and Regional Government (1988) Michael Bassett, the Minister of Local Government, outlined his reform objectives. He envisaged providing councils with a power of general competence to enable them to respond flexibly and innovatively to the needs of their communities. His loss of office in 1990 meant that this phase was never completed until Labour's return to power in 1999 .
} 
transparent and accountable decision-making processes - arguably the first stage of a process of institutional and procedural modernisation. Rationalisation was driven by the failure of voluntary consolidation policies and the continued growth in the number of elected bodies, approximately 850 (single- and multipurpose bodies). These were consolidated into 86 multi-purpose local authorities. The Local Government Commission, set up after the Second World War to deal with the issue of local government fragmentation but without the necessary 'teeth' to do so, was finally empowered to manage the rationalisation. It was required to consult councils and communities before adopting its schemes and completed the process in time for the 1989 local authority elections. ${ }^{6}$ While the commission addressed the consolidation challenge, the Government amended the LGA 1974 to introduce many of the organisational design features that were reflected in the reform of the national public sector. Its key high level objectives included the following:

- that objectives should be stated in such a way that all parties providing public goods and services are clear about their roles

- that accountability should be maximised, primarily by measuring and assessing performance against objectives

- that competitive neutrality should minimise costs and provide incentives and sanctions to enhance efficiency

- that managers should be free to manage without undue interference from those assigned to represent community values.

The reforms ultimately represented a marriage of the two primary objectives driving the reform of the national public sector, efficiency and accountability (Boston 1991), with a third objective that had particular salience to local government, the enhancement of democratic participation. It also framed the policy tensions that would drive subsequent reforms. For example, the new framework sought to bolster the quality of democratic leadership while at the same time limiting the freedom of elected members to act as their community's

\footnotetext{
${ }^{6}$ Set up in 1946, the commission's powers were reduced in 1953, strengthened in 1961 and again in 1967; but amalgamation was left for electors' polls to finally determine (Bassett 1996).
} 
representatives by strengthening the distinction between management and governance. It encouraged participation and public deliberation while also removing a number of functions, such as ports, airports and trading enterprises, from the direct public or democratic domain. Finally, it constrained capacity of elected members to make operational decisions through the introduction of new planning and consultation requirements which sought to encourage a strategic perspective. The new approach operated within a framework which shifted the model of local democracy away from a purely representational one to something of a hybrid, informed by greater citizen participation. There were significant changes:

- the introduction of formalised annual planning and budgeting

- the publication of annual reports detailing performance

- the introduction of formalised consultation procedures for major decisions

- the removal of employment decisions from councils, apart from those regarding their chief executives

- the separation of regulatory and non-regulatory roles

- the separation of policy and operational roles

- the transfer of commercial activities to 'arms-length' entities

- the creation of a new form of sub-municipal organisations called community boards

- the creation of a national system of regional councils with responsibility for environmental policy and environmental management (with the exception of Gisborne District, which combined both territorial and regional functions).

In short, the reforms established organisations which, unlike their predecessors, had the capacity and capability to think and act strategically. Equally important was the subsequent shift to accrual accounting and output budgeting. Both were necessary to provide councils with the tools to enable them to take a more strategic - understood as 'steering' - approach, with more contestability and more ex ante performance specification. Modernisation of the institutions and 
processes employed by local authorities and the creation of more substantial local government units were perceived as the means rather than the goal of the process. The architect of reform, Michael Bassett, said some years later:

I wanted technically stronger, functionally more efficient and politically more accountable local authorities with whom central government could discuss meaningful devolution of functions to the local level ... to move to the next stage which I saw as enactment of a general power of competence... (Bassett 1996, p. 34).

The next general election defeated the Minister's plans for completing the reform process and left plans for general empowerment and devolution unfinished. The chair of the Local Government Commission, Sir Brian Elwood, was less ambitious than the Minister, commenting four years after the reforms were completed that "there is now ... a system of governance which allows the option of choosing a centralised, regional or local community approach to policy making, service delivery and political accountability" (Elwood 1993, p. 2). In the event it was left to the incoming National Government to explore these options, albeit with a different set of policy objectives.

In terms of community governance, the major contribution of the 1988/89 changes was enhanced capacity and the introduction of consultation as a way of strengthening voice and engagement. One measure was the establishment of community boards in more than 40 councils. These boards were composed of elected members, elected at the local authority triennial elections, and councillors appointed to the boards. The Local Government Commission justified the boards on the basis that some councils were likely to be so large that former communities of interest might lose representation. However, critics saw it as a way of buying the co-operation of small councils that were about to be consolidated. ${ }^{7}$ The legislation set a minimum level of functions for a community board which emphasised advocacy and representation; some councils regarded them as a useful mechanism for devolving functions so that

\footnotetext{
${ }^{7}$ Discussions between the author and officials and elected members.
} 
they would be undertaken in close proximity to communities. Christchurch City Council made use of this opportunity to a greater degree than most other local authorities. However, some councils saw the boards as an unnecessary level of democracy and sought to remove them. In the early years, community boards could vote to disband themselves, and at least one council, Hauraki District Council, ensured that each board was allocated enough appointed councillors to enable them to form a majority. Within a year, each board had voted to disband itself. The LGA 2002 removed this method for disbanding boards and allowed such decisions to be appealed to the Local Government Commission, which was required to hold public hearings. Very few boards have been disbanded since that time, although some consolidation has occurred and new boards have also been established by the commission.

The previously fragmented nature of the local system meant that some councils lacked the technical skills or resources to undertake an effective governance role. Nor were their boundaries coterminous with communities of interest, making effective long-term community strategies almost impossible. There was one area, however, where the changes might be seen as having a negative effect on the potential for community governance, and this was the nature of the newly established regional councils. The creation of regional councils, with a narrow focus on environmental policy (shortly to be further reduced in 1992), limited the ability of the New Zealand local government system to both plan and undertake services at a regional level - something that had already begun to occur through the emerging united councils. A further change that received no critical comment at the time was the overall reduction in the number of elected members and the resulting increase in the 'representation ratio' (see Chapter 7). Although councils could in theory have up to 30 councillors, only one council, Christchurch City, had anything near that figure, with 24 . The trend to reduce representation was carried on by decisions made by the Local Government Commission when undertaking its triennial representation reviews.

The change of government in 1990 saw a brief halt to reform and some decisions were unwound, namely the reintroduction of limits on the Local Government Commission's ability to initiate consolidation and a reduction in the 
role and number of regional councils. However, it was not long before local government reform was once again on Parliament's legislative agenda.

\section{The second phase: financial management}

The next significant period of local government reform occurred in 1996 with the passage of the Local Government Amendment Act (No. 3) 1996 (LGAA3). The LGAA3 introduced new and more rigorous financial management provisions. The Acting Minister of Local Government at the time explained the purpose of the bill as follows:

its predominant objective is to require local authorities to identify explicitly the reasons for their funding proposals. This will engender public consultation and promote funding decisions that are clearly representative of the wishes and values of their communities (Graeme Lee MP, Hansard, 28 March 1996).

While the LGAA3 was partly a local government version of the Fiscal Responsibility Act 1994, which had enhanced the transparency of central government's financial management, it also addressed a wider set of issues with its requirement that councils consider the reason for undertaking each activity. It introduced some critical changes:

- a requirement to prepare and adopt Long-Term Financial Strategies (LTFS) - 10-year plans outlining expected income and expenditure

- a requirement to fund depreciation or any reduction in the service potential of assets and infrastructure

- a requirement to develop specific funding policies for each activity based on an assessment of the associated public and private benefits

- a requirement to prepare borrowing and investment strategies.

An important innovation was the requirement that councils develop Long Term Financial Strategies. These strategies, which outlined council income and expenditure for each major activity for at least 10 years, were the first formal 
requirements on councils to plan strategically on a functional basis. (They formed the basis of the Long Term Council Community Plan (LTCCP), which was introduced six years later in the LGA 2002.) While the LGAA3 gave councils more freedom to borrow and raise funds from capital markets (it abolished the Local Authorities' Loans Board, allowing councils to raise loans directly from banks and financial organisations), the requirement to fund depreciation proved to be a major financial challenge, as many councils were obliged to address a backlog of deferred maintenance. The primary mechanism for meeting this requirement was the development of detailed asset management plans, a requirement few councils were able to meet at the time. Preparing accurate plans detailing the existing and future state of their infrastructure required explicit assumptions about future demand and development over the medium and long term.

The LGAA3 continued the drive for more economic efficiency that was present in the earlier period of reform (Reid 2002). Two of the primary mechanisms, the funding policy and the LTFS, required councils to subject all activities to an economic analysis in order to justify continued public provision and to determine what form of funding or mix of funding instruments would provide the best match between those who funded and those who benefited from services. Underlying the process was the assumption that councils would gradually focus on those services for which public provision is most appropriate and leave those for which public provision was not necessary to the private or voluntary sectors.

This proved a highly contentious approach as councils publicly assessed their roles and reasons for undertaking them, particularly traditional services such as libraries. The assumption behind the reforms appeared to be that the process of rational analysis and public scrutiny would over time reduce the range of "noncore' council activities and increase efficiency. And that funding would shift progressively from ratepayers to users. The requirement created considerable angst as councils debated the relative public and private benefits resulting from each activity, deciding sometimes on wildly divergent proportions of benefit for the same functions. Some councils operated on the assumption that the level of private benefit created by an activity should also reflect the level of funding 
sourced from user charges. Proposals to increase user charges were inevitably contentious and a number of councils made highly public retreats from such proposals, such as charges for library books. However, despite popular perceptions, no significant increase in user charges resulted from the LGAA3, although there was a notable move away from general rates towards uniform charges for specific services, such as water supply, libraries or waste treatment.

The LGAA3 effectively built on and enhanced many of the changes introduced in the previous reforms, such as accrual accounting and established processes that would provide councils with the information to make strategic decisions about role and scope. It promoted the idea of the local state as an enabling organisation, sufficiently free of historical and political constraints to be able to rationally analyse its functions in terms of economic principles and determine how they should be funded. The new financial management provisions were intended to give elected members and managers the information necessary to encourage more strategic decisions. As a result, some councils sought to reinvent themselves as 'smart purchasers', the idea that councils should be free from operational commitments and 'steer' their communities without the distraction of 'rowing'. Indeed a number of councils, such as Papakura District Council, became well known for their vigorous approach to contracting out their services to the private sector, driven by the way in which the legislation encouraged them to think smarter.

The focus on transparency and efficiency failed to address the fundamental question of what objectives the councils were trying to achieve for their communities. Without any legislative requirement to develop strategic plans, councils were driven by the funding and financial needs of their asset and infrastructure investments. The overriding financial imperatives, of funding their asset management plans and dealing with historic under-investment, took precedence over any serious questions about the degree to which assets and services fulfilled broader community outcomes. In terms of any contribution to community governance, the LGAA3 was largely neutral, although the introduction of the LTFS built up a capacity and information base that placed councils in a much better position when it came to undertaking community 
planning when it was introduced six years later. The Long Term Financial Strategy required councils to think, if not explicitly then implicitly, about the type of community they wished to have in the future as they debated issues around future levels of service. The LTFS built a capacity for long-term planning which is one of the preconditions for effective community governance.

\section{The third phase: empowerment}

Within four years of the enactment of the LGAA3, although less than two years after the date of compliance, ${ }^{8}$ a new Labour-Alliance Government had been elected to the Treasury benches with a manifesto promise to rewrite local government's empowering legislation. It also agreed to complete the review of local government's rating legislation undertaken by its predecessor and rewrite its electoral statute. Although the push for a substantial rewrite of the LGA 1974 can be dated back to the 1996 Local Government Association conference, ${ }^{9}$ it did not achieve momentum and political endorsement until both the Labour and Alliance parties adopted it in their manifestos, three years later. Both supported a power of general competence for local government, although the Alliance was perhaps closer to a localist agenda than Labour. Labour stuck with the familiar public policy themes of transparency and responsiveness, wanting "local bodies to operate with autonomy and freedom within a collaborative framework that allows levels of government to work for the best outcomes for communities" (Labour Party Election Manifesto 1999). In contrast the Alliance went to the heart of the matter, arguing the need to:

restore the autonomy, minimise central government control over local government affairs, and put the local back into local government [and] that local government functions best when local democracy and community self-determination are given the greatest scope (ibid).

\footnotetext{
${ }^{8}$ The size of the information needs required to fulfil the LGAA3 led the Government to give councils until July 1998 to fully comply.

${ }^{9}$ The Conference resolved to ask the government to "rewrite the tablets" - the three core statutes governing councils' powers, funding and electoral processes.
} 
While the formation of a Labour-Alliance coalition government and their separate manifesto commitments provided the preconditions for another wave of local government reform, it took the active intervention of the Prime Minister to make reform one of the government's priorities. Despite competing demands for time and resources, the Government agreed to hold a 'roundtable' meeting with representatives of the local government sector within three months of achieving office. That first meeting, branded as a central-local government forum and subsequently repeated every six months, resulted in a public commitment by the government to rewrite the Local Government Act and provide the necessary resources. Creating a modern, flexible statutory framework sat comfortably with the new government's call to rebuild the capacity of the public sector generally, and especially its desire to move towards more collaborative and holistic (in the sense of taking into account social, economic and environmental matters) forms of governing. ${ }^{10}$ In its own words, the Government acknowledged that:

the challenges facing New Zealand in areas such as sustainable development cannot be met by central government making decisions and acting on its own. They require a partnership approach within which central government, local government and the voluntary and business sectors can work together (Lee 2001, p. 13).

Very quickly the review came to be situated in the post-modern discourse of diversity and partnership - themes consistent with the Government's approach to public service as a whole and which were also reflected in the way the review itself was undertaken (see SSC 2001).

\section{The Government's objectives}

While local government sought the modernisation of its primary statute in order to reduce complexities created by its age and history of incremental reform, the Government's objectives for the review of the LGA 1974 were to enact a new statute which:

\footnotetext{
${ }^{10}$ See The Review of the Centre, 2001, State Services Commission, Parliament (www.ssc.govt.nz).
} 
- reflected a coherent overall strategy on local government

- involved a move to a more broadly empowering legislative framework under which local authorities could meet the needs of their communities

- involved the development of a partnership relationship between central and local government

- clarified local government's relationship with the Treaty of Waitangi (ibid, p. 6).

The objectives provide a useful insight into the resulting framework. The reference to empowering councils to meet the needs of their communities reinforces the long tradition of bottom-up accountability in the New Zealand model of local government and moves away from any perception that councils are an arm of national administration. The reference to a partnership between central and local government also appears to acknowledge that local government has, or should have, a capacity for independent or autonomous decision-making and that partnerships, by definition, can only exist when both partners can exercise free will. While it was not developed in the early literature on reform, the idea of local-central partnerships invokes the Third Way ideology of New Labour in the United Kingdom and the idea of 'joined-up government' (JUG). It is also one of the fundamental tenets of community governance theory.

The idea of partnership was reflected in the review process itself. The Government invited local authority officials to work alongside its own officials in the policy development phase of the review, in which a number of joint project teams worked on different aspects of the draft legislation. In a further innovation Local Government New Zealand (the association of local authorities) was allowed to express its views on relevant cabinet papers on the same basis as government departments. This occurred in all aspects of the review, except the development of policy in relation to the Treaty of Waitangi, a precedent replicated in other policy areas, such as amendments to the Resource 
Management Act, transport reform and the ill-fated attempt to merge the volunteer and professional fire services.

The result of the process was the Local Government Act 2002, enacted in a parliamentary environment of vigorous debate, during which it was described by the parliamentary opposition, the National Party, as the "biggest constitutional change for New Zealand since the introduction of MMP" (The Independent, 27 November 2002, p. 8). ${ }^{11}$ The Independent, a business weekly, referred to it as part of the Government's "socialistic agenda" while the Northern Employers and Manufacturers Association speculated that "business could be faced with miniature Kiwibanks competing with private business" (ibid, p. 8). Geoffrey Palmer, a former Prime Minister and constitutional lawyer, favourably located the new Act in the same tradition as the "third way philosophy espoused by Bill Clinton and Tony Blair" (ibid, p. 8). Adding to the diverse interpretations the legislation received, Local Government New Zealand referred to the statute as bringing long-awaited modernisation to the local government sector. As noted above, many credited it with introducing a new paradigm for local government (Leonard and Memon 2008, Cheyne 2008) and the changes it brought about were widely regarded as extensive: ${ }^{12}$

- the replacement of a highly prescriptive statute based on ultra vires principles with a general empowering clause, extended to both territorial (district and city) councils and regional councils ${ }^{13}$

- new purpose statement

o to promote the social, economic, environmental and cultural wellbeing of communities, in the present and for the future

o to enable democratic decision-making and action by, and on behalf of, communities (s12, LGA 2002)

\footnotetext{
${ }^{11}$ MMP is the Mixed Member Proportional voting system introduced for New Zealand's Parliament after a referendum in the mid 1990s.

${ }^{12}$ Unlike many jurisdictions, the New Zealand practice has been to separate funding powers and general powers into different statutes. A new Rating Act was also enacted in 2002.

${ }^{13}$ Regional councils were created in the 1989 reforms, with primary responsibilities for regional environmental policy and planning. Their empowerment through the LGA 2002 was greeted with dismay by most districts and cities, which were concerned about the possibilities of duplication and competition. In response, the legislation contains various checks and balances to delay/prevent an increase in regional functions without the agreement of cities and districts.
} 
- the introduction of a set of principles including an obligation to take a sustainable development approach

- a requirement to identify community outcomes in collaboration with other agencies, including government departments

- more emphasis on long-term planning (a requirement to prepare a Long Term Council Community Plan at least every three years) and a corresponding diminution of annual planning

- requirements to consider options, costs, benefits and impacts before making decisions, relative to the significance of the issue

- a requirement to report every three years on the achievement of community outcomes

- more emphasis on providing opportunities for citizens to participate in decision-making processes

- the codification and publication of core policy documents and information to increase transparency

- a requirement to build capacity and provide opportunities for Maori to participate in decision-making processes

- the ability to levy developers to pay for the cost of infrastructure

- enhanced bylaw-making powers

- provisions to prevent the privatisation of water-related services, including limitations on councils' freedom to contract out the management of water service networks.

Many of the new provisions, such as the focus on community defined outcomes, well-being and collaboration, reflect themes also promoted by community governance theorists, particularly in the United Kingdom and codified in that country's local government reforms in 2000. However, the scope of the changes was also influenced by historically determined factors unique to New Zealand. The legislation sought to marry a much broader range of policy objectives than 
previous reforms attempted ${ }^{14}$ and has been interpreted as weakening the previous decade's emphasis on efficiency (Kerr 2003). The focus on accountability that has infused reform since 1988/89, however, continued to be prominent. The Government declared in an early discussion document that:

the approach being taken to the review is that the likelihood of a broader range of permitted activities for local government will require rigorous provisions for mandate and accountability to local communities..... Further work being undertaken includes:

- the potential for a strategic planning focus that articulates the outcomes sought from involvement in particular activities

- the design of decision-making frameworks that focus on the consideration of relevant information and on high levels of transparency

- the provision of understandable information to members of the public

- the identification of appropriate provisions requiring public consultation and participation in decision-making processes that reflect the significance of the issue or activity concerned

- ways of enhancing participation by and accountability to citizens (DIA 2000, p. 12).

The Statement of Policy Direction for the Review of the Local Government Act 1974 (DIA 2000) was the first public document of the reform process and was published primarily to inform the national community of the Government's intentions. The statement set out the high level principles and the Government's overall direction for the future shape of local government. It also explicitly highlighted the importance of councils having to secure a greater community mandate for their decisions than previously existed.

\footnotetext{
${ }^{14}$ For example, despite the much-heralded 'power of general competence' (since rebranded as 'general empowerment'), the Act contains considerably more prescription - in some areas, such as water and water services - than in the previous 'prescriptive' legislation.
} 
Sound processes will be required to enable councils to identify the social, economic and environmental outcomes that their communities want them to pursue. Those processes will involve councils securing a community mandate for activities that are intended to advance the achievement of particular outcomes (DIA 2000, p. 7).

The emphasis on mandate reflected a widely held view, particularly among members of the newly elected government, that the previous decade with its minimalist political philosophy had diminished the efficacy of the public sphere and that there was a need to reinvest in the state sector. It was believed that the same was true of local government, particularly given some councils' enthusiastic embrace of privatisation, a matter of considerable interest to the Minister of Local Government when she was in opposition. The example of Papakura District, which, as noted above, had developed a governance model based on the management of contracts (and was viewed as a model of good practice by some national business groups), simply reinforced the Minister's concern that local government had been captured by the political right. The result was a decision by the Government to legislate to prevent councils from privatising their water services. The Minister's views were also influenced by her experience as an Alliance councillor (a left leaning coalition of smaller parties) on Auckland City Council during a period when the council was dominated by a conservative political grouping. As a member of a left wing political group that was suspicious of the modernisation reforms of the 1980s, Lee found the Auckland City Council's right-of-centre approach confirmation that the sector had lost touch with the interest of its communities. This shaped her approach to reform in 2002.

Greater accountability to communities was reinforced with the publication of the Government's second consultation document (DIA 2001), although little attention was given to the nature of 'community' and the problem of defining collective interests. This document, which attracted a wide range of submissions, provided for the first time a detailed set of proposals for the future 
shape of local government. ${ }^{15}$ It promoted an ambitious vision of an empowered local government system able to respond effectively to the community's aspirations, in which "citizen involvement is essential to defining community goals and taking action to advance these" (ibid, p. 3). The emphasis on community outcomes was both a reference to the council's role in setting future directions based on community preferences as well as a mechanism to ensure accountability. In fact the accountability emphasis was perhaps stronger in the early unpublished drafts of the Government's discussion document, namely the statement:

the community needs certainty about the elected council's use of broad empowerment and adherence to the principles of local government. The community needs a minimum level of assurance about ... delivery intentions and what they actually deliver (Unpublished draft Discussion Document, April 2001).

The weight the Government placed on the notion of councils providing assurance to the community about their intentions captures the Minister's general view of councils' performance during the 1990s, a view that was quite critical.

\section{Tracking the origins of the LGA 2002}

Local government reform never occurs in a vacuum. The history of local government reform in New Zealand has been the result of a combination of economic pressures, political ideology and sheer luck. It is also strongly pathdependent with changes constrained by existing historical influences and circumstances (Dollery and Robotti 2008). While the themes of accountability and transparency dominated the first and second phases of reform, and continued to influence phase three, new influences were also apparent, particularly the idea that local government had a role in the wider project of community governance (as opposed to organisational governance). While such

\footnotetext{
${ }^{15}$ In contrast to the Statement of Direction, which received relatively little publicity, over 20,000 copies of the Consultation Document were distributed, 26 public meetings were held and 650 submissions were received.
} 
notions of local government's role were widely discussed internationally, they were also, by the late 1990s, being openly debated in New Zealand.

One such influence was a conference hosted by Christchurch City Council in June 1999 entitled 'Community Governance: the Christchurch Forum'. Participation in the forum was by invitation only; approximately 150 attended made up of a cross-section of mayors, chief executives, officials and community representatives. The overall focus of the forum was to look at the challenges facing government in Christchurch, Canterbury and New Zealand; and a background paper, 'Taking the Canterbury Communities into the New Millennium', was prepared by the Christchurch City Council and circulated to participants in advance of the forum. Participants were provided with a mix of local and international speakers and a considerable part of the forum consisted of workshops based around a number of key questions. International speakers included Professor Michael Clarke, from Birmingham University, and Professor Robin Hambleton, who, more recently, has been advising the Royal Commission on Auckland Governance and prepared one of their background papers (see Hambleton 2008). Also provided to participants was a Community Governance Kit (Richardson 1999b), which described a new style of local government, one more focused on the outcomes the community wants rather than its traditional role as service provider.

In achieving community governance the key skills lie with facilitation, networking, dialoguing and participation in ways that recognise that decision-making is spread across a range of groups and individuals (Richardson 1999b, p. 3).

The forum focused on the pace of social change, the complexity of the issues facing governments at the end of the millennium and, with more than a little reference to the new approach to public policy being espoused by the recently elected Labour Government in the United Kingdom, argued that addressing these issues was beyond governments and markets acting independently (Giddens 1999). Ownership of these issues was seen to belong to the community as a whole. Reference was made to the need for governments, 
local, regional and national, to provide a strategic leadership role as well as to acknowledge their unique mandate, derived from their democratic status. Interestingly, it was suggested that councils should adopt this new style of governance voluntarily rather than having it imposed by legislative reform, although providing councils with either general competence or the status of a legal person was recommended as helpful. Specific recommendations were made, such as promoting the sharing and exchange of ideas and good practice, providing peer support, and promoting and explaining the concept of community governance to groups and individuals. In addition, emphasis was given to facilitating a change to the relationship with central government. While a proposed community governance network to promote and pursue the forum's recommendations never eventuated, the momentum created by the forum can be seen in some of the provisions included in the LGA 2002 and ultimately the proposals put forward by the Royal Commission on the Governance of Auckland.

The Christchurch forum was one of a series of influences that are likely to have contributed to the design and final shape of the LGA 2002, yet despite this the place occupied by the LGA 2002 in the history of local government legislation is still a matter of contention. Some writers (see Reid 2002, McKinlay 2004, Cheyne 2002) argue that it represents the final stage of a relatively coherent process of local government reform and is best understood from the overall perspective of public sector modernisation (see Chapter 4). Other commentators (see Kerr 2003) find less coherence and more often see the statute as diversionary and threatening to reverse what they see as advances achieved in the first two phases of reform. While the new statute has a level of coherence which was missing in its predecessors, the question relevant to this thesis is to determine the degree to which the theories of community governance might have contributed to this coherence, and whether the new statute has strengthened the potential for community governance.

The legislation changed the purpose, principles, process and powers of local authorities, although not as extensively as some commentators have suggested, particularly those who argued it represented a major constitutional 
change. The explicit reference to promoting well-being in the purpose statement, the recognition of sustainability in the principles and the requirement to identify community outcomes - a form of community strategic planning suggest an awareness of the instruments commonly associated with community governance. This shift in emphasis, which had been signalled in the election manifestos of both the Labour and Alliance parties, was subsequently reinforced by the proposals contained in the Government's Statement of Policy Direction (DIA 2000) and Consultation Document (DIA 2001). Both reflected a number of key narratives, namely increasing opportunities for community participation, increasing councils' accountability to communities, and strengthening co-ordination among public agencies. For example, the Government's Consultation Document (DIA 2001) highlighted the importance of encouraging more engagement and participation by citizens in local government and flagged for the first time the concept of desired community outcomes.

One of the underlying objects of the review of the LGA is to encourage increased participation of citizens and communities in local government. ... Citizens and communities want to tell councils what their aspirations are and seek information from their councils about how these aspirations can be met. It is proposed that long-term council plans will include the identification of desired community outcomes (DIA 2001, p. 8).

The rationale for such objectives was to be found in the Government's view of its predecessor's approach to local government reform. In particular it was convinced that the additional consultation and planning requirements, particularly those introduced by the LGAA3, had failed to deliver the optimal level of democratic responsiveness. The Minister of Local Government, the Hon. Sandra Lee, expressed this view in a number of speeches that were critical of the level of community participation in council affairs.

Way back in 1995 my Department surveyed local authorities and it found that a significant amount (sic) of councils were still receiving fewer than 20 submissions ... I had a hunch that 5 years later many people are still not getting involved in local government. A quick ring around some 
regional councils confirmed my suspicions. Only a small number of people are still participating in the annual planning process (Local Government Regional Communications Conference, Wellington, March 2000). ${ }^{16}$

The LGA 2002 sought to address the Minister's concerns by introducing requirements for community-driven processes, such as establishing what outcomes the communities sought from their local governments and creating opportunities for Maori to participate in decision-making. Specifically, S82 of the LGA 2002, which sets out consultation principles, extends the judicial definition of consultation by requiring councils to be proactive in enabling affected and interested parties to express their views on decisions that potentially affect them. Higher level principles are also expressed through s14, which includes references to community diversity, the interests of future generations and the need to consider the views of communities. These provisions reflected a new approach to thinking about the role of local government as more than simply the provider of a range of discrete services.

\section{Redefining the concept of local government}

Four aspects of the new statute are particularly salient to the discussion on the degree to which it redesigned local government as a form of community governance. These are the new emphasis on well-being; broader powers; the LTCCP; and community outcomes. Each is discussed below.

The focus on well-being

The LGA 2002 provided councils with a new statement of purpose to promote their community's social, economic, environmental and cultural well-being, now and for the future. ${ }^{17}$ This was a somewhat broader brief than that given to councils in the United Kingdom, a power of well-being that provided a mechanism for councils to act outside their delegated authority in order to

\footnotetext{
${ }^{16}$ While the Minister's brief survey revealed that regional council annual plans received relatively few submissions, it was a big step to conclude that this experience was typical of the sector as a whole. Even at this stage the average number of submissions territorial authorities were receiving on their annual plans was more than 300 .

${ }^{17}$ Colloquially referred to as the 'four well-beings'.
} 
promote social, economic and environmental well-being. The new purpose introduced by the LGA 2002 applied not only to the present but also to the future. Although 'well-being' is not defined in statute the common approach appears to treat the phrase as representing a state of secure livelihood, health, safety, happiness and fulfilment in practice. Such approaches are largely utilitarian, taking into account how citizens feel about their communities and how they compare with similar jurisdictions across a number of domains, such as environmental quality and personal safety.

In making decisions about promoting well-being and fulfilling their purpose, councils are expected to either contribute to enhancing all four well-being dimensions or make explicit trade-offs between them. For example, a decision to increase social well-being by increasing residential housing so as to reduce overcrowding is likely to have potential environmental costs, such as the loss of open space, natural habitats and amenity. Such trade-offs were to be recognised and made in an explicit and transparent way. They were also to be made in a manner that ensured affected communities have an opportunity to have their views on the matter considered, appropriate to the significance of the decision in question. There are frequent references to enhancing well-being throughout the LGA 2002, especially in relation to decision-making:

- Section 62(1)(b) requires councils, when making decisions, to assess options in terms of their effects on the four well-beings.

- Section 73(2)(a) requires councils as part of their community outcomes process to provide opportunities for communities to discuss their outcomes in terms of the four well-beings.

- Section 82(1)(b) requires that councils include in their LTCCPs any significant negative effects that activities might have on the four wellbeings (LGA 2002).

Promoting social, economic, environmental and cultural well-being and advancing community outcomes are two of the key drivers of councils' strategic decision-making processes. Clarity about community preferences - 'outcomes' - is meant to ensure that councils are aware of the community's needs and 
preferences and provide a mechanism for aligning policies and priorities with resources. They do not, however, diminish the responsibility of the local authority to consider the impact of its activities on well-being. Councils are also required to use their judgement as to whether or not the outcomes specified by their communities are compatible with sustainable development, another objective of the legislation.

\section{Broader powers}

The Government's broad vision for reform is reflected in the sweeping changes to local government's powers, purpose, principles and decision-making processes with the new empowerment clause being particularly contentious. Despite local government's status as a creature of statute, the new powers are widely drawn:

s12(2) For the purpose of performing its role, a local authority has

(a) full capacity to carry on or undertake any activity or business, do any act, or enter into any transaction and

(b) for the purposes of paragraph (a) full rights, powers and privileges (LGA 2002)

The shift from an ultra vires regime to one of general empowerment reflects a general reduction in legal supervision of local government by the state, of both an ex ante and ex post nature. Banner (2002) suggests that this decline in direct supervision reflects both the increasing capacity of local governments, as a direct consequence of consolidation, and a greater willingness by citizens themselves to use official mechanisms, such as judicial review, to complain if they feel their rights have been violated. Protecting the rights of citizens and ensuring councils use their 'new' powers wisely has been an overt consideration of all phases of local reform since 1988/89, but was particularly influential in the design of the accountability provisions in the LGA 2002, which put in place a framework that emphasised accountability to citizens and communities rather than to higher levels of government. 
The Government's decision to provide councils with general powers created concerns about accountability and mandate and whether or not local authorities could be trusted to use the powers wisely. Concerns about accountability, and in particular the potential risks that might be created by the removal of the doctrine of ultra vires, influenced much of the Minister of Local Government's approach to the review. The Government's first discussion paper on the review and the power of general competence in particular (DIA 2000), discussed the need to identify areas of activity from which local government should be excluded, suggesting areas such as the funding of core social services and the "conduct of New Zealand's international relationships" (ibid, p. 8). However, the proposed proscriptions failed to advance as far as the publication of the second discussion paper, the imaginatively entitled Consultation Document (2001), and were not incorporated in the final statute. In the face of sector concerns that any list might be interpreted in a way to prevent reasonable local government activity, the Government relented. Yet the perception that strong checks and balances on the use of local government's new powers were still needed did not diminish.

The parliamentary opposition, along with various interest groups, vigorously opposed any power of general competence for councils. For example, Gerry Eckhoff MP, speaking on behalf of the ACT Party, began a critical press release with the statement, "Powers of competence damnify citizens' rights," and went on to lambaste the Government for the foolishness of giving local politicians such powers (ACT press release 16 July 2001). ${ }^{18}$ These views were backed up by interest groups like Federated Farmers and some national business lobbies which argued, wrongly, that business paid half the rates and should have been given greater opportunity to influence the final design of the legislation.

The proposed power of general competence posed a dilemma for the Government and its officials. The prospect of such legislation increasing the power of local government politicians provoked critics to raise fears about

\footnotetext{
${ }^{18}$ In a possible irony, the same MP, having lost his seat in the 2002 general elections, stood for, and was elected onto, the Otago Regional Council in October 2007.
} 
councils crowding out the private sector and acting irresponsibly with ratepayers' funds. ${ }^{19}$ The Government's challenge was to assure the public that councils would not 'misuse' their new powers, and that with power would go responsibility. As noted above, the Government placed great importance on strengthening accountability, or at least on being seen to have listened to critics. Consistent with this, the Minister, the Hon. Sandra Lee, stated strongly in her First Reading Speech that the Bill was about:

the empowerment of New Zealanders within their local communities to exercise even greater control over their elected representatives and councils, and over the environments and communities in which they live (Lee 2001, p. 3).

The point was reiterated in the Minister's speech to Federated Farmers in November 2001 when she said that "transparency and accountability issues have formed an integral part of the review. As I have stated very clearly in the past .... with power must go responsibility and more accountability back to the community" (Hon. Sandra Lee, Novotel Hotel, Wellington, 21 November 2001, p. 3). The Minister's various public statements suggested the legislation was primarily designed to ensure that councils were accountable to their communities for delivering the goods and services that their communities wanted, rather than allowing them to do whatever they liked. An important mechanism for determining their wants and preferences was the new requirement to identify community outcomes, providing councils with knowledge about the outcomes citizens aspired to.

While the suggestion that councils should do what their communities want, as revealed by negotiated outcomes, had a simplistic appeal, it made a number of assumptions about the ability of councils to forge consensus within frequently very diverse places. While the final shape of the legislation avoided such crude linkages, the idea of the community outcomes process as an instrument of 'accountability' (see below) became embedded in the resulting framework. The

\footnotetext{
${ }^{19}$ Leading those concerns was the Local Government Forum, a consortium of national business and farming organisations.
} 
Long Term Council Community Plan (LTCCP) was to be the mechanism for its delivery and councils were required to show the degree to which council activities contributed to the achievement of community outcomes within each LTCCP. This accountability concept rests on the assumption that if a council acts in a manner contrary to the will of the community (as expressed in statements of desired outcomes) sufficient information will be available for the discrepancy to be apparent, subject to local debate, and ultimately resolved in the next election.

While the new powers provide a more empowering environment for councils in New Zealand, it is important not to overstate the limitations of the previous statute, which, despite its highly prescriptive nature, contained clauses that gave councils wide discretion. Although councils had won additional freedoms with the LGA 2002 (at the cost of new procedural requirements), some things had not changed. Their range of policy and functional responsibilities remained the same and there was little promotion of devolution - indeed centralising pressures to standardise the delivery of local services continued to increase. Faced with more complex and expensive procedural requirements, many rural councils, quite comfortable with their historical role, wondered what they had gained other than more compliance. For many, the more limited framework of the LGA 1974 was entirely sufficient, particularly given their emphasis on local infrastructure, and they saw little reason to congratulate the reformers. To such councils many of the new LGA 2002 requirements, such as community strategic planning and taking a sustainable approach, presented an unwelcome change. $^{20}$

\section{The Long Term Council Community Plan}

The key mechanism for promoting well-being and sustainable development under the LGA 2002 is the LTCCP and its particular approach towards organisational and community strategic planning. The LTCCP is an enhancement of the Long Term Financial Strategy (LTFS) introduced by the National Government in 1996 (the LGAA3). It incorporates the key features of

\footnotetext{
${ }^{20}$ Conversations between the author and a number of rural mayors.
} 
the LTFS, on which were grafted greater process and information requirements. It is now the primary driver of local government strategy, in the sense of longerterm planning, and there is a statutory obligation for councils to review and adopt an LTCCP at least once every three years. The stated purpose of the LTCCP is to:

- set out the community outcomes and the local authority's intended contribution to those outcomes

- set out the things the local authority will be doing over the life of the plan

- co-ordinate the activities of the local authority

- provide a long-term focus for the local authority

- provide a means for communities to hold the local authority accountable

- provide an opportunity (potentially the primary opportunity) for the public to participate in local decision-making (LGNZ 2003, p. 32).

The LTCCP must also be adopted in accordance with the special consultative procedure, with consultation required during each stage of its preparation. ${ }^{21}$ This last requirement ensures that citizens' input will be more extensive in the early stages of development than occurred under the previous long-term planning framework, the LTFS. The LTCCP can be seen as a kind of proxy contract between a council and its community - outlining in detail where a council is heading, how it will get there, how it will fund the journey, and the rules and processes that will apply. It was also meant to address a weakness in the previous framework which was seen to overemphasise short-term planning due to the dominant role played by the annual plan in council business. ${ }^{22}$ Under the new framework annual planning was intended to become little more than consultation over the annual budget, as no major change can be undertaken without triggering a full LTCCP review.

\footnotetext{
${ }^{21}$ The Special Consultative Procedure was introduced in 1989 as a statutory consultative process that must be used when councils adopt their annual plan or other major and significant decisions.

${ }^{22}$ Indeed one local authority, New Plymouth District, has recommended to the government that the requirement to consult on the annual plan be dropped, as consulting raises expectations in communities that they will be able to make changes, which is unrealistic within the LTCCP framework.
} 
The LTCCP is, in short, something of a hybrid, part corporate plan and part strategic plan, while also providing a snapshot of the council's strategy and policy development at a point in time. An innovative measure introduced by the LGA 2002 required each draft LTCCP to be reviewed by the Office of the Controller and Auditor-General and to contain a statement about the degree to which the assumptions the plan is based on are reasonable. However, the administrative demands involved in its preparation and the cost of audit clearance have been major financial issues for many councils and threaten to overshadow the audit's intended strategic focus. As well as the core strategic document for the district/region, it is also the primary document for a number of other objectives:

- financial accountability

- political accountability

- transparency

- meeting obligations to Maori

- stewardship of public assets and infrastructure

- co-ordinating service providers to contribute to community outcomes.

Once a plan has been adopted, the ability to change course is very limited unless a council is prepared to undertake the expense of reviewing its LTCCP before the statutory review deadline of three years has passed. ${ }^{23}$ Its comprehensive nature reflects the importance the Government has placed on long-term planning and greater certainty of investment intentions, particularly with regard to investment and maintenance of infrastructure and the state of local public assets. A critical aspect of the new planning model, however, is the requirement to identify community outcomes, state and describe how they were identified in the LTCCP, and show how council activities will contribute to the achievement of the outcomes. It represents a strongly rationalist conception of public decision-making involving the articulation of ends (outcomes) and

\footnotetext{
${ }^{23}$ In what was probably an oversight the LGA 2002 requires a full audit of the LTCCP whenever an amendment is made, however minor. This has since been removed with the passage of the LGA 2002 Amendment Act No. 3.
} 
ensuring the ability to debate and make meaningful choices between different strategies for achieving those ends.

\section{Community outcomes}

The need to provide communities with better information so as to hold their councils to account and plan for the future was a frequent theme in the development and promotion of the new legislation. For example, in her first reading speech the Minister of Local Government, Sandra Lee, claimed that:

to be successful councils must in the future be driven less by a need for strict compliance with a detailed statute, and more by the need to deliver results that local communities demand (First Reading Speech, December 2001).

The requirement itself is written in broad terms and requires councils to conduct a process, not to produce a particular document or plan (see Figure 1). The purpose of undertaking the outcomes process can be traced back to many of the themes that surrounded the Government's rationale for the review of the LGA 1974. It is to:

- provide opportunities for communities to discuss their desired outcomes in terms of the present and future social, economic, environmental and cultural well-being of the community

- allow communities to discuss the relative importance and priorities of identified outcomes to the present and future social, economic, environmental and cultural well-being of the community

- provide scope to measure progress towards the achievement of community outcomes

- promote better co-ordination and application of community resources

- inform and guide the setting of priorities in relation to the activities of the local authority and other organisations (s73, LGA 2002). 
The legislation is quite specific in describing the role councils should play in the outcome identification process. Councils must identify, and then invite, other organisations, those able to influence outcomes, to assist in the design of the process for outcomes identification. The process must be undertaken at least once every six years. The way in which the legislation attempts to place the community (as represented by, for example, the not-for-profit and business sectors) in the decision-making role ahead of councils and elected members raised immediate questions about the relative merits of representative and participatory democracy.

Figure 1 Long Term Council Community Planning framework

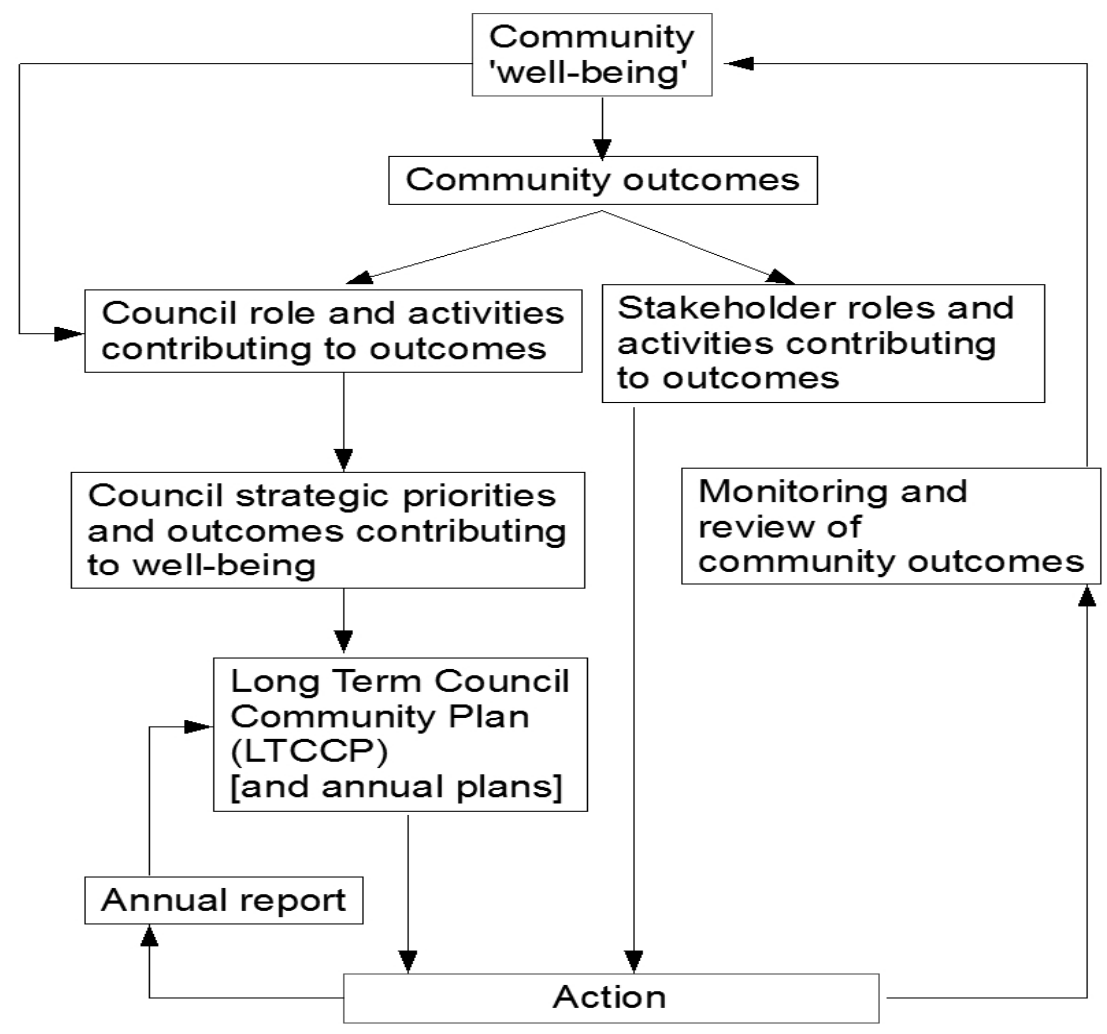

(Source: adapted from Local Futures' unpublished Local Futures Working Paper) 
The decision to incorporate community outcomes into councils' long-term planning processes was intended to address a perceived weakness in the Long Term Financial Strategy (LTFS) framework. Advice to Cabinet's Policy Committee described the LTFS as providing:

(c) a financial context for particular council activities but not recognis(ing) and integrat(ing) the Council's social, cultural and environmental reasons for undertaking activities. As a result, the way that these social, cultural and environmental plans and activities fit into the whole Council programme is not clear. This approach does not provide elected representatives with the information they need ... (Council Planning and Decision-Making Processes, POL Min (01) 12/17, 18 May 2001).

In the cabinet's mind the shortcoming of the LTFS was its failure to provide a strategic context, such as the desired outcomes, for which council assets are held and which would allow decision-makers and the public to make informed judgements about the levels of service that such assets should provide. The Cabinet Policy Committee was concerned that the LTFS placed too much reliance on fiscal considerations and that there was a need for balance with social, cultural and environmental considerations. It believed that councils should be engaging in dialogue with their communities and that local government was a crucial leader in determining how community assets should be used. In their view elected representatives should be able to decide between doing things because it is the most efficient way of resolving an issue and doing them because the community has other values, such as cultural concerns or a focus on jobs. The Long Term Council Plan (LTCP) ${ }^{24}$ was proposed so that councils could group together all of the things they currently do, or plan to do, to improve the future of the community and manage the assets of that community in an integrated way.

${ }^{24}$ The Long Term Council Plan evolved into the Long Term Council Community Plan. 
Having established a broad empowering framework and requiring councils to facilitate a process to discover their various communities' outcomes, the Government then appears to have had a failure of nerve. Despite the prescribed processes and frameworks, the outcomes are given little status other than a requirement that councils must show how their activities contribute to them. It begs the question as to which agency should now be responsible for achieving these outcomes - it was not clear that it should be local government.

The Government's Consultation Document (DIA 2001) expressed the idea of desired community outcomes in the context of council planning, consultation and reporting. Unlike the earlier publication, the Statement of Policy Direction (DIA 2000), it clearly states the purpose of the review as "to encourage increased participation of citizens and communities in local government" (DIA 2001, p. 37). If participation was to increase, the community would need information from councils about what they intended to do and deliver. It is interesting to note that over the two-year period during which the LGA 2002 was developed, the proposition that the process of identifying desired community outcomes will increase community engagement and consultation became increasingly more prominent in the Government's policy documents. From an initial focus on steering and accountability the Government's agenda expanded to include the desirability of greater citizen participation.

It is also noteworthy that the wording of s91 of the LGA 2002 is framed so as to require the creation of opportunities to actively participate rather than consult. While the statute contains a detailed set of consultation principles (s82, LGA 2002) the legislation does not specifically refer to consultation when addressing the role of the public in the process of identifying community outcomes preferring a more discretionary and ultimately less compliance-orientated framework. Between the introduction of the requirement to consult on specific types of decisions in the first phase of reform in 1988/89 and the emergence of a legal definition of consultation, concerns had arisen that council approaches to consultation were more concerned with statutory compliance and meeting the legal definition than with the spirit of the legislation. By avoiding the language of consultation and settling for a more general requirement that the process should 
allow communities to contribute to the identification of outcomes, the legislators sought to encourage a process that would be more responsive to community diversity and less likely to be compliance focused.

A critical reason for the Government's decision that councils identify community outcomes was to enable communities, as well as elected members and stakeholders, to assess the council's performance towards enhancing wellbeing and achieving outcomes. This objective fulfils a number of familiar purposes such as enhancing transparency, strengthening accountability and enabling communities and others to make informed judgements about progress towards a future which, if the purpose of local government according to the Act is met, should be sustainable. In this way the accountability theme represents a continuation of the changes introduced in 1988/89, and in particular the influence of New Public Management (NPM) theory, which sought to bring private sector management techniques into the public realm.

The focus on identifying outcomes and reporting on progress towards their achievement is consistent with the objectives of greater transparency and accountability. It is also, and this reflects one of the tensions in the legislation, indebted to community governance theory, much of which was a reaction to the managerialism of NPM. This tension partly explains the range of experiences identified in the case studies of community planning (see Chapter 5 ) with some councils looking to exploit the community governance potential and others treating community outcomes as only a compliance requirement. The LGA 2002 approach mirrors the requirement placed on councils in the United Kingdom to participate in Local Strategic Partnerships and develop sustainable community strategies, a core feature of community governance. Yet in both countries the multi-faceted nature of outcomes means that councils cannot achieve outcomes by themselves. The contribution of many agencies, as well as individual volition, is required.

The requirement to identify community outcomes in order to strengthen accountability also fits clearly with what might be described as the strong localist tradition of New Zealand local government, which emphasises 
accountability to communities rather than to the Crown. This is in stark comparison with local government in the United Kingdom, which is strongly accountable to Whitehall-based officials. ${ }^{25}$ In early advice to the New Zealand government on the local government review, officials described accountability as involving the availability of information about what is being done and its expected consequences and noted that participation and consultation are important elements of increasing community capacity to influence decisionmaking (Working Paper 'Local Government Act Review - An Overview of Key Issues', DIA, 18 December 2000). If the idea of accountability to communities was to work, even in an environment in which councils have been given greater freedoms, then transparency, participation and process would need to be enhanced, particularly if the overall outcome was better quality of life for communities.

A different form of accountability was also introduced by the requirement that draft LTCCPs be subject to audit in order to review the reliability of the information on which the plans were based. The audit of the LTCCPs - each draft LTCCP receives an audit clearance or qualification - was justified as a form of accountability as it was expected to contribute to citizen confidence in local governments' decision-making processes. The external audit process has been controversial from the moment it was introduced, primarily for the cost, which, for a small council, can represent the equivalent of a 2 per cent rise in the rates bill for that year. Yet the process of subjecting draft plans to close inspection by auditors, who check that assumptions are reasonable and that statutory provisions, particularly in financial management, performance management and asset management, are met has resulted in a substantial improvement in the quality of the plans (OAG 2010).

The requirement to identify community outcomes is also one of the primary mechanisms for realising the government's objectives for enhancing coordination, addressing fragmentation and improving collaboration between

\footnotetext{
${ }^{25}$ In contrast, the performance of local government in the United Kingdom is assessed against a suite of nationally determined indicators - the comprehensive performance assessment, on which basis all councils are ranked from low to excellent.
} 
agencies. It is perhaps the most important feature to those who argue that the LGA 2002 represents a model of community governance. The legislation places emphasis on the need for councils to provide opportunities for other agencies, such as non-governmental organisations, public agencies, and business organisations, to influence the design of the process by which they intend to identify outcomes. The concept was explicitly endorsed by the then Minister for Social Development, Steve Maharey, who described the community outcomes process as "strengthening the whole of government collaborative activity", and said that "this is already happening in many local authority areas" (quoted in McKinlay 2004, p. 79).

Addressing the significance of the new outcomes' requirement, McKinlay (2004) argues that the outcomes process is a whole-of-community strategic planning approach and represents a "fundamental shift from conventional local authority planning and consultation" (ibid, p. 13). In his view the new Act, underpinned by the community outcomes process, is a departure from previous regimes, in which the core business of councils was the provision of infrastructure, arts, culture and recreation facilities. He argues that, in order to achieve this model, councils would need to become actors in the broad range of issues affecting their communities, including those where they currently have a minor or no role as a service provider. While the provision was undoubtedly a new requirement (an impost in the view of many) for most councils, it can also be seen as simply formalising what had become best practice, particularly the innovative multiagency approaches to strategic planning undertaken by councils such as Manukau and Porirua. ${ }^{26}$ The LGA 2002 framework built on their experience and sought to encourage councils to work with other public and non-public agencies on the resolution of local and regional issues, whether they wanted to or not. ${ }^{27}$

\footnotetext{
${ }^{26}$ During the review process government officials sought a briefing from officials from both councils about their approach to strategic planning.

${ }^{27}$ The LGA 2002 was passed in an environment of increasing awareness of the value of networks and joined-up government (Ryan 2003) and this new emphasis can also be seen as part of an historical pattern. Gill (2008), for example, argues that the election of the Labour Government in 1999 signalled a third phase in the nature of public administration in New Zealand. Phase one, 1912-1984, represented governance by hierarchies; 1984-1999, governance by markets and contracts; 1999-2008, governance by networks, hierarchies and communities.
} 


\section{The impact of reform on intergovernmental relationships}

The concept of governance (see Chapter 2) highlights the importance of collaboration, agencies working in alignment to achieve common objectives. It has relevance to the relationship between local and central government. This is not an issue that received much, if any, attention in the first two phases of local government reform. That focus was primarily concerned with the performance of the sector and, despite radical change, the way in which local and central government related was left largely untouched. The LGA 2002 changed this, not dramatically but enough to make the issue of intergovernment relationships an ongoing matter of policy interest in both spheres of government. The result was a series of initiatives and institutional arrangements that, despite criticism that they did not go far enough (see Thomas and Memon 2007, Local Futures 2006), were quite unique for the New Zealand constitutional arrangement.

The historical relationship between local and central government in New Zealand, from its emergence in the mid 19th century to radical reform at the end of the 20th century, can be summed up as one of benign neglect or resigned failure. The difficulties faced by successive governments since the late 19th century to implement a systemic programme of reform is well documented; however, following the major reforms of 1988/89 Parliament has been unusually focused on local government and its activities, as has also occurred throughout much of the OECD (Sullivan et al 2006). Unlike the European model, the New Zealand state, particularly since the 1930s, has been strongly centrist, with a preference for national solutions to social and economic problems. With the 'big' issues like welfare, education and justice firmly in the hands of the centre, there has been little national interest in the specifics of local government activity (Reid 1999). The big local government expenditure items were largely underground and relatively inelastic - roads, drainage, water supply systems - which meant that Parliament generally left councils to get on with the business of their operation with little interference, which perhaps explains the high level of financial and functional autonomy of the New Zealand local government model. Had New Zealand councils been responsible for the provision of social services, 
which are more likely to attract the interest of rent-seeking groups, arguably parliamentary interest would have been that much greater.

\section{Whose outcomes?}

One of the challenges faced in any alignment process involves articulation of goals. How well do the participating sectors articulate their desired outcomes? The modernisation of the New Zealand public sector achieved considerable clarity around output specification and accountability for delivery; it was less successful when it came to providing a whole-of-government response to issues. As early as 1991 Basil Logan diagnosed a lack of effective strategy formulation as a problem for the new approach to public management (Boston et al 1996). The government's initial response to this challenge was a document entitled 'The Path to 2010', adopted in 1993, which contained a strategic vision for New Zealand organised around a number of Strategic Result Areas (SRAs). SRAs were in effect outcomes and one of their effects was to provide officials with a clear indication of the government's priorities. These areas were subsequently elaborated to translate the vision into a focus for departmental activity by adding Key Result Areas (KRAs); these were incorporated in departmental Statements of Intent (SOIs). KRAs had a three-year focus and were designed to correspond with the life of chief executives' performance agreements. The SRAs, despite their national focus, anticipated many of the outcomes that have since emerged in councils' community outcomes processes, nearly a decade later. SRAs covered economic growth, enterprise and innovation; external linkages; education and training; community security; social assistance; health and disability services; Treaty settlement claims; and the environment. Each also contained a description of desired outcomes and a list of related activities for the following three years.

The adoption of SRAs was a response to concerns about a lack of a strategic focus, fragmented government and consequential policy risk. At about the same time, councils were starting to comply with the requirement to produce a Long Term Financial Strategy (LTFS). Introduced by the LGAA3, it was largely assetdriven with little obvious fit with the Government's SRA framework; however, enterprising councils, such as Manukau City Council, attempted to use SRAs as 
a statement of government policy and endeavoured to make explicit links with their own strategy documents, such as in the area of economic development. However, other than Manukau City's innovative response, the strategic planning approaches of the two spheres of government operated largely independently, contributing to a perception that public services lacked strategic co-ordination. It also raised the question of whether or not, and if so how, local and central government should be working in alignment.

While government agencies were developing their internal strategies for engaging with local authorities and ways to relate to 85 diverse and autonomous bodies (the amalgamation of Banks Peninsula District and Christchurch City in 2005 reducing the total to 84 ), the local government sector was more concerned with how to determine which government departments and agencies were appropriate to approach as participants in the community outcomes identification process and whether or not there were relevant national outcomes or strategies that they should take into account.

While both central and local government use outcome-based planning models, the approaches are quite different (the incoming Labour-led Government in 1999 decided not to continue the SRA/KRA framework of its predecessor). Central government has no overriding obligation to promote the four wellbeings, and to the degree which these objectives are shared between local and central governments is a matter for the political preferences of the government of the day. Questions also arose about which sector's outcomes or objectives should take precedence. In those policy areas where central government has clearly defined outcomes and strategies there is no necessary assumption that they should override locally determined versions, particularly if they conflict. However, in the first few years following the passage of the LGA 2002 the immediate challenge was finding the right agency to engage with around the community outcomes process.

Community outcomes set the context for intergovernmental collaboration and, in theory at least, the process provided a basis for government agencies and councils to establish dialogue on priorities and roles. Yet co-operation was 
ultimately contingent on the political commitment of the institutions and their institutional capacity and capability - the success of any collaboration reflecting the willingness of agencies to subordinate their own agency's goals to the goals of the community, or in some cases the nation. Clarification came in June 2004 when cabinet agreed on the level and nature by which central government agencies were to engage in the community outcomes process - an essentially voluntary basis, as cabinet noted:

- There is no specific level or type of engagement required by departments, rather departments who engage in community outcomes processes will determine their appropriate level of participation.

- Ministers will still retain responsibility for the government's policy goals and priority outcomes, and decision-making authority over the allocation of public resources in relation to those goals and priorities (POL Min (04) 12/15, CAB Min (04)18/4).

While government departments continued to worry about how to relate to numerous local authorities, councils were puzzling about how to recognise the Labour-Alliance Government's own strategic goals. Without an explicit statement of Strategic Result Areas such as those employed by their predecessors, where should they look? Are departmental objectives the equivalent of government objectives? What constitutes a high level whole-ofgovernment objective anyway? Apart from a brief list of election commitments (the pledge card), the first few years of the Labour-led Government were characterised more by pragmatism than explicit high level policy direction. The vacuum came to be populated by the development of what might be termed 'meso-strategies' in that they sought to achieve mid level, medium-term policy goals or outcomes.

Meso-strategies represent an attempt to build a whole-of-government commitment to an intermediate purpose and to the degree that they are broadly focused and properly mandated they can provide public signposts to the government's middle-term aspirations. Meso-strategies adopted by the Labourled Government that had some relevance to local government included the 
Sustainable Development Plan of Action, the Growth and Innovation Framework, the Transport Strategy and, in the social domain, Opportunity for all New Zealanders. Given the emphasis on taking a sustainable development approach within the LGA 2002, the Sustainable Development Programme of Action (POA) also provided a good example of government strategy-making that had the capacity to influence local outcomes. The POA was an umbrella strategy with four discrete areas - sustainable cities, energy, child and youth development, and water. In each of these areas the role of local government and the importance of working collaboratively were acknowledged, although with varying degrees of commitment. For example, in respect of water the POA states:

There are a significant number of stakeholders at the local, regional and national levels with an interest in water issues. ... There is a need for robust decision-making, particularly by regional councils, who are responsible for the key resource management decisions and consideration of the values of the different stakeholder groups. Strong partnerships with local government, central government agencies, industry, Maori, and the community are therefore desirable to create innovative and enduring approaches to managing our water resources (POA 2003, p. 14).

The sustainable cities strand was also relevant to local government and advanced, for a time, under the leadership of the Ministry for the Environment. The POA set out two overarching outcomes in this area:

- cities as centres of innovation and economic growth

- liveable cities that support social well-being, quality of life and cultural identities.

Under this umbrella the strategy addressed a wide range of urban issues, such as migrant settlement, urban form, design and development, Auckland's regional economic development, and sustainable communities. Unfortunately, the Ministry for the Environment's intention to develop a statement of strategic 
priorities was not completed in time to influence councils' 2006-16 LTCCPs, thus diminishing the potential of the strategy to achieve more effective alignment.

The Ministry of Social Development leads the child and youth development strand, and although councils are only providers of services at the margin, they are recognised throughout. In bringing together previous strategies, such as the Agenda for Children and the Youth Development Strategy, the department's new meso-strategy, 'Opportunity for all New Zealanders', made specific reference to the role of councils. The strategy provided a mandate for Ministry of Social Development officials to promote child and youth issues in community outcomes processes facilitated by councils throughout New Zealand.

\section{Departmental initiatives}

Intergovernmental collaboration was signalled early in the local government reform process. One of its review objectives was "The development of a partnership relationship between central and local government" (DIA 2001). The idea of a partnership relationship contrasted sharply with the practice of its predecessor during the 1990s. Following enactment of the LGA 2002, the Government adopted a number of measures to facilitate engagement between its own agencies - primarily departments and Crown entities - and councils. Its approach gave departments and agencies the right to negotiate relationships relevant to their briefs. Four departments were each given the authority to take the lead in the four well-being areas; these were the Ministry for Culture and Heritage, the Ministry of Economic Development, the Ministry of Social Development and the Ministry for the Environment. Each was allocated the wellbeing corresponding with their portfolios.

The nature of the engagement between government departments and local governments reflected a range of styles from active to largely passive (see Table 3). For example, the Ministry for Culture and Heritage, which has no regional presence, held a series of regional workshops for councils attended by its chief executive; the Ministry for the Environment held a travelling roadshow, while the Ministry of Economic Development, which was similarly mandated, 
simply provided additional information designed for local authorities on its website. In contrast the Ministry of Social Development established a series of regionally based offices with considerable delegated authority and encouragement to work with councils on collaborations to address social issues. A number of other departments and Crown entities have also sought to build relationships with councils, particularly since the passage of the LGA 2002, for example, the Human Rights Commission, which regards local government as an important/useful mechanism for strengthening commitment to gender and racial equality. Individual departments and ministries were left to decide for themselves the degree to which collaborating with councils would assist in meeting their outcomes and agencies were encouraged to adopt innovative and entrepreneurial engagement strategies. Initially there were concerns about the capacity of departments and agencies to engage with all 85 local authorities and the cost of doing so. In order to address such concerns councils were encouraged to either cluster together to facilitate co-operation or work under the umbrella of their regional councils. In fact, at least one of the lead government ministries - the Ministry of Economic Development - decided to limit its engagement to the regional sphere of local government.

Table 3 Examples of engagement initiatives

- DIA local government interface facilitation team

- Deputy Secretaries Group

- Ministry for Culture and Heritage roadshows

- Ministry of Social Development (MSD) regional policy advisers

- Publication by MSD of a Good Practice Guide for Working with Local Government

- Whole-of-government strategies such as the Growth and Innovation Framework

- Ministry of Economic Development's web-based tool kit

- MSD's Good Practice Guide for Working with Local Government

- Human Rights Commission workshops for local authorities 
Despite the lack of a coherent whole-of-government approach, a number of departments appear to have recognised opportunities for creating synergies with local authorities. The Ministry of Social Development, the Police and Fire Service have all been among the more active, exploring the potential for councils to contribute towards achieving their departmental outcomes and working with councils to achieve community outcomes.

\section{Encouraging collaboration}

In practice, engagement arose from councils' requests and government initiatives, despite the institutional difficulties, which were substantial. For example, central government agencies are organised very differently from councils; the process of responding to council requests stretched some agencies, and their cultures can also be very different, with a less clear boundary between the political and administrative spheres in local government. To assist collaboration cabinet established a Deputy Secretaries Group (see Figure 2) as a mechanism for achieving a whole-of-government agreement towards the mechanics of central-local collaboration. In addition the Department of Internal Affairs established a regional team of officials, the local government interface facilitation team, which was given responsibility for promoting better engagement between the two sectors. ${ }^{28}$

\footnotetext{
${ }^{28}$ The interface group was disbanded within the first year of the National-led Government in 2009 as part of its cost-cutting strategy.
} 
Figure 2 Structure of inter-agency initiatives

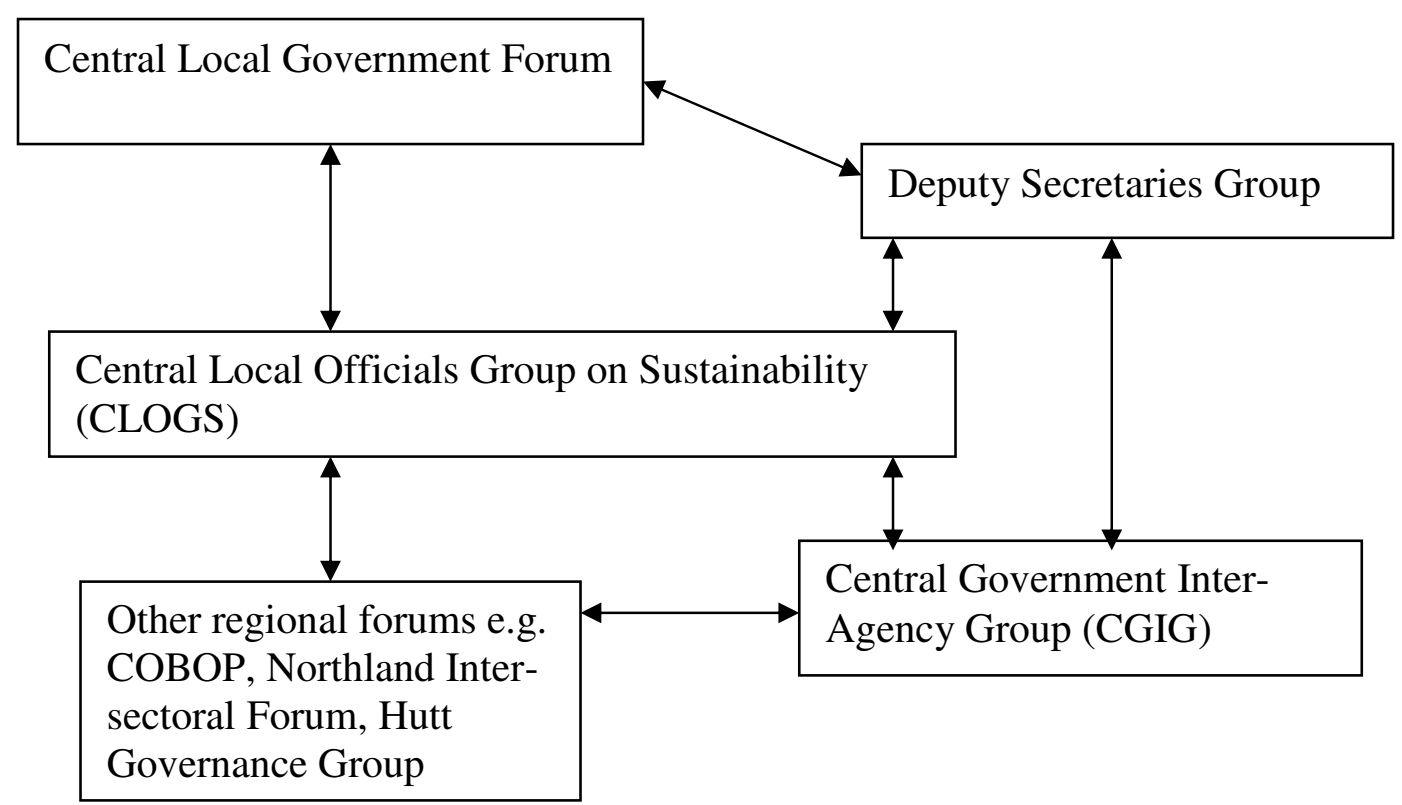

The framework described in Figure 2 highlights the significance of the Central Local Government Forum, a six-monthly meeting between the cabinet and the board of Local Government New Zealand, representing the local government sector. The forum is relatively unique by international standards in that it creates a space in which representatives of the two sectors can meet and engage in dialogue as equals. ${ }^{29}$ Historically, local government concerns have been (and still are throughout most of the year) dealt with by the Minister of Local Government, a position that is normally lowly ranked in terms of cabinet seniority and which in practice is concerned with the management of the relationship in order to reduce political risk. ${ }^{30}$ With the establishment of the first forum in March 2000 the local government sector discovered a mechanism for bypassing the institutional filters that operate within departments and was able to raise concerns directly with appropriate ministers, who, under the watchful gaze of the Prime Minister, were frequently tasked with finding solutions.

One of the results of the forum has been a tendency to refer issues to joint officials' groups in an explicit recognition that many of the problems faced by local government require a joined-up approach. Two examples are worth noting,

\footnotetext{
${ }^{29}$ The National-led Government has reduced the frequency of the forum to one a year.

${ }^{30}$ After the 2008 elections the post of Minister of Local Government was given to a minor party in the coalition and placed outside cabinet.
} 
the Central Local Officials Group on Sustainability (CLOGS) and the Social Sector Forum, the latter being a bi-monthly meeting involving representatives of the major urban councils and social policy ministries that share practice on topical social issues, such as family violence, tagging, alcohol and social housing (the forum was discontinued by the National-led Government in late 2009). Another example of joint working occurred at the 2005 forum. Following concerns raised by local government presenters at the financial pressures faced by councils it was agreed to establish a joint officials' group to examine the sustainability of local government funding. Though the group reported back in 2006, its work was soon overtaken by the Local Government Rates Inquiry, which was undertaken by an independent task force established that same year (DIA 2007). The importance placed on better engagement also led to the Deputy Secretaries Group agreeing to a series of regional meetings with local government chief executives to enable better communication. As of the beginning of May 2008 two such regional meetings had been held, in Otago and Canterbury.

Innovative approaches to alignment

A number of city, district and regional councils found innovative ways to align their various planning and strategic documents, some of the most innovative involving regional clusters of councils. The Taranaki region, for example, sought to use the community outcomes process as a mechanism for aligning public providers. Using various techniques, including surveys, public meetings and hui (normally used to describe meetings held in marae, traditional meeting places for Maori, the consortium of councils involved in the outcomes process set 10 outcomes, which were ranked for priority and analysed to determine which public agencies in the region should have lead responsibility for achieving them. The Taranaki model (see Table 4) can be thought of as a network with individual agencies pursuing their own goals within a collaborative framework. The decision to build the collaboration around agreed community outcomes and defined lead agency status provides an effective illustration of the model of community planning as it has emerged under the LGA 2002, including the facilitative nature of the local government role. 
Table 4 Taranaki outcomes and lead agency

\begin{tabular}{|l|l|l|}
\hline & Outcomes ranked by importance & \multicolumn{1}{|c|}{ Lead agency } \\
\hline 1 & $\begin{array}{l}\text { Acceptable level of/access to local } \\
\text { health services }\end{array}$ & District Health Board \\
\hline 2 & People feel safe in Taranaki & Police \\
\hline 3 & Quality of streams, rivers and lakes & Taranaki Regional Council (TRC) \\
\hline 4 & Education/training opportunities & Education Taranaki (cluster) \\
\hline 5 & Road access to/from Taranaki & Transit/Land Transport NZ \\
\hline 6 & $\begin{array}{l}\text { Protect quality of water around } \\
\text { coast }\end{array}$ & TRC \\
\hline 7 & $\begin{array}{l}\text { Higher levels of employment } \\
8\end{array}$ & $\begin{array}{l}\text { Vatural character of coastline } \\
\text { Development Agency (EDA) }\end{array}$ \\
\hline 9 & More prosperous regional economy & $\begin{array}{l}\text { New Plymouth District Council with } \\
\text { TRC and Dept of Conservation } \\
\text { (DOC) }\end{array}$ \\
\hline 10 & Protect native bush and wildlife & TRC with DOC \\
\hline
\end{tabular}

(Source: New Plymouth District Council, 2006, www.communityoutcomes.govt.nz)

More than 200 agencies were involved in the process of determining outcomes in the Taranaki region. A core group was established to supervise the identification process and promote their achievement. The core group, Future Taranaki, involved major public agencies, such as the Department of Conservation and the Ministry of Social Development, the local authorities, and representatives of voluntary and not-for-profit organisations, tertiary education providers and Federated Farmers. Having identified a set of regional outcomes, Future Taranaki next focused on monitoring the degree to which they were being achieved, and monitoring reports have been published annually (see http://www.trc.govt.nz/Future-Taranaki/). 
The Taranaki example indicates that collaboration based around local and nationally agreed outcomes is possible, although there is no necessarily correct formula for their design. In contrast little progress appears to have been made towards developing new institutional models that would enable joint purchasing or access greater levels of funding from the state, in order to achieve the outcomes. Neither is it clear how much influence the collaboration has had on setting national departmental priorities and targets - there has been little or no evidence of outcomes information being used to influence or inform national programmes or priorities. More recently the election of a National-led Government in 2008, with a commitment to focus more on 'doing' rather than 'strategy', has seen the dismantling of many of the Labour Government's collaborative initiatives, such as the Deputy Secretaries Group and the Interface Team. The result has been a different environment for central-local collaboration; just how different might be indicated by the government's approach to the consolidation and reform of Auckland, its biggest metropolitan area.

\section{The Auckland governance report - the outcome}

The report of the Royal Commission on Auckland Governance (2009) was notable not just for the degree to which it drew on concepts of community governance in its proposed design for the new city but also for the way in which the government quickly dismissed many of its key recommendations. ${ }^{31}$ For example, gone were the explicit partnership mechanisms around economic development and social well-being (although both Ministries have been asked to look at the question of how to achieve better alignment and report back to the government). Gone also were the proposed Minister for Auckland and Cabinet Committee on Auckland. In its response to the Commission's recommendations the government undermined many of the proposals for ensuring the new council, which will be responsible for over one million residents, would take a holistic approach to the region's governance.

\footnotetext{
${ }^{31}$ Making Auckland Greater: The Government's Decisions on Auckland Governance, April 2009, New Zealand Government.
} 
Despite the government's response, it is significant for this project that three highly experienced former public servants, with minimal local government experience ${ }^{32}$ came to conclude after 18 months' consideration that the Auckland metropolitan area needed a radically different governance model - a model that departed from the traditional local government approach and drew heavily on new ideas of community governance. The failure of the commission to convince the government to endorse its overall concept for Auckland, particularly the elements which stressed collaboration and governance, also highlights the degree to which urban policy has historically been lacking in government policy in recent decades. While the Labour-led Government gave the topic at least lip service (it appointed a Minister for Urban Affairs in the 2002-2005 Parliament and established various officials' groups to advise on urban sustainability), ${ }^{33}$ neither of the two main political parties has a comprehensive urban policy able to address the specific needs of cities, although the new government is developing a national standard on urban design, which may address some of the gaps.

Given the lack of an existing urban framework, consideration of the commission's report appears heavily influenced by what, in reality, are policy slogans, such as 'Getting Auckland moving'; 'Keeping the rates down'; 'Reducing the number of politicians' and the Minister's goal of "One city, one mayor, one rates bill" (the Hon. Rodney Hide 2/4/2009). ${ }^{34}$ While the commission worked hard in the two weeks after the release of its report to convince the government to implement it in its totality, it is difficult to see how they could have been surprised at the government's response - a response that does not appear to be convinced of the merits of collaborative governance as a way of governing the country's urban areas. Despite this, the government has placed considerable store on citizen engagement in the new city by rejecting the commission's recommended six local councils with its own proposals for between 20 and 30 local boards, each with extensive decision-making

\footnotetext{
${ }^{32}$ One Commissioner had been an elected member more than two decades earlier.

${ }^{33}$ CLOGS, Committee for Local Government Sustainability.

${ }^{34}$ www.nzherald.co.nz/nz/news/article.cfm?c_id=1\&objectsid=10564788.
} 
powers. ${ }^{35}$ While the new model for Auckland governance falls short of the somewhat more radical vision put forward by the Royal Commission, it will continue to exist within the framework of the LGA 2002, its principles, processes and purpose.

\section{Conclusion}

Like many local government systems, the New Zealand system has been subject to ongoing reform, which, with the looming reform of Auckland's governance arrangements, is unlikely to come to an end any time soon (the government has also signalled an intention to change to the LGA 2002 and the RMA 1991). In effect, reform itself has become the norm. This creates major difficulties for councils' planning and delivery of long-run infrastructural services as the willingness of successive Parliaments to amend their governing legislation can only result in an unstable and uncertain environment. It is beyond the scope of this thesis to determine why local government in Zealand has been the target of so much legislative interest since 1989 (major reform seems to occur every seven years or so), but the increasing politicisation of the local-central government relationship and incentives on political and bureaucratic actors to be seen to be 'doing something' must be factors. Although arguments for reform tend to be framed as necessary for efficiency and accountability, change is seldom based on an agreed problem definition or accompanied by an estimate of costs and benefits (see Table 5 for a summary of the major reform initiatives). With reference to local government, the traditional disciplines governing cabinet decision-making appear to be relaxed, with slogans replacing analysis, and a pattern of ignoring international research that recommends caution (see McKinlay 2006).

${ }^{35}$ For example, local board chairs have been given the right to conduct citizenship ceremonies. 
Table 5 The story of local government reform

\begin{tabular}{|c|c|c|c|}
\hline Dimensions & Phase 1: 1989 & Phase 2: 1996 & Phase 3: 2002 \\
\hline $\begin{array}{l}\text { Size and } \\
\text { structure }\end{array}$ & $\begin{array}{l}\text { Consolidation and } \\
\text { capacity growth } \\
\text { Limitation on the } \\
\text { role of regional } \\
\text { councils }\end{array}$ & $\mathrm{N} / \mathrm{A}$ & $\begin{array}{l}\text { More ability to } \\
\text { transfer services } \\
\text { between TAs and } \\
\text { RCs }\end{array}$ \\
\hline Empowerment & $\mathrm{N} / \mathrm{A}$ & $\mathrm{N} / \mathrm{A}$ & $\begin{array}{l}\text { General } \\
\text { empowerment }\end{array}$ \\
\hline Finance & $\mathrm{N} / \mathrm{A}$ & $\begin{array}{l}\text { Long-Term } \\
\text { Financial } \\
\text { Strategies } \\
\text { improve public } \\
\text { confidence in } \\
\text { council finances } \\
\text { and decision- } \\
\text { making }\end{array}$ & N/A \\
\hline $\begin{array}{l}\text { Central } \\
\text { government } \\
\text { supervision }\end{array}$ & $\mathrm{N} / \mathrm{A}$ & $\mathrm{N} / \mathrm{A}$ & $\begin{array}{l}\text { Introduction of the } \\
\text { Central Local } \\
\text { Government Forum } \\
\text { Increase in national } \\
\text { policy statements }\end{array}$ \\
\hline Functions & $\begin{array}{l}\text { Devolution of } \\
\text { environmental } \\
\text { management }\end{array}$ & $\mathrm{N} / \mathrm{A}$ & $\begin{array}{l}\text { New statement of } \\
\text { purpose and } \\
\text { principles }\end{array}$ \\
\hline Strategy & $\begin{array}{l}\text { Greater } \\
\text { transparency and } \\
\text { requirement to } \\
\text { consult }\end{array}$ & $\begin{array}{l}\text { Long-term } \\
\text { financial } \\
\text { strategies }\end{array}$ & $\begin{array}{l}\text { Community } \\
\text { outcomes }\end{array}$ \\
\hline Leadership & $\begin{array}{l}\text { Elected members } \\
\text { refocused on }\end{array}$ & $\mathrm{N} / \mathrm{A}$ & $\begin{array}{l}\text { No reference to } \\
\text { leadership in }\end{array}$ \\
\hline
\end{tabular}




\begin{tabular}{|l|l|l|l|}
\hline & $\begin{array}{l}\text { matters of strategy } \\
\text { rather than } \\
\text { operation }\end{array}$ & N/A & $\begin{array}{l}\text { government } \\
\text { rhetoric }\end{array}$ \\
\hline Collaboration & N/A & $\begin{array}{l}\text { Requirement to } \\
\text { collaborate over } \\
\text { outcomes } \\
\text { Discretionary for } \\
\text { government } \\
\text { agencies }\end{array}$ \\
\hline $\begin{array}{l}\text { Decision- } \\
\text { making }\end{array}$ & $\begin{array}{l}\text { Mandatory } \\
\text { consultation }\end{array}$ & N/A & $\begin{array}{l}\text { Principles to } \\
\text { involve citizens in } \\
\text { process of } \\
\text { decision-making }\end{array}$ \\
\hline $\begin{array}{l}\text { Local } \\
\text { democracy }\end{array}$ & $\begin{array}{l}\text { Reduced levels of } \\
\text { representation }\end{array}$ & N/A & $\begin{array}{l}\text { Reduced levels of } \\
\text { representation }\end{array}$ \\
\hline
\end{tabular}

(Factors that may potentially weaken the ability to achieve community governance are noted in italics.)

Despite the politicised nature of the reform process and its frequency, the LGA 2002 signalled a new style of governing based on an arguably more constructive relationship with central government and its agents, more opportunity for citizens to influence decision-making, and more opportunities for inter-agency approaches at the local level. In summary, the model of local government that has emerged in New Zealand has managed to balance traditional concerns, such as accountability, transparency and fiscal management, with a sprinkling of concepts drawn from broader governance theories, particularly those associated with local government reform in the United Kingdom. Some of the basics were unchanged; powers were clarified; some additional funding tools were provided, but they were of marginal utility to only a few councils; ${ }^{36}$ and the constitutional relationship was left unchanged. The question remains, however, whether or not these changes were sufficient

\footnotetext{
${ }^{36}$ Reform provided councils with the ability to levy development contributions and targeted rates.
} 
to enable local government in New Zealand to respond to the challenges of the new millennium and deliver enhanced well-being and quality of life to their citizens. These are challenges that are likely to require a broader range of skills and policy interventions than possessed by traditional forms of government; they require the co-ordinated efforts of numerous local, regional and national organisations working together - governance as well as government. 


\section{Chapter 2 Community governance theory}

This chapter explains the concept of community governance with reference to definitions of governance and community governance used in the academic literature. The recent history of the concept 'community governance' is recounted and the relationship between community governance and local government analysed.

The concept of governance has received considerable scholarly attention in recent years. Initially it was seen as a synonym for government (Dent et al 2007) but as the role of informal actors in public decision-making became more widely recognised the concept began to attract attention from a broader academic church, including people with interests as diverse as public administration, international relations, overseas aid and more responsive forms of service delivery (Rhodes 1997, Schout and Jordan 2005, Bovaird and Loffler 2007, Kjaer 2004). In her seminal work on the topic Kjaer identifies five major theoretical approaches to the concept; these are outlined in Table 6.

Kjaer suggests that concepts of governance are defined in terms of the rules by which institutions operate as well as the enforcement of those rules. 'Governance' focuses on both the input side, concerned with democratic procedures, and the output side, which is concerned with efficient and effective institutions. In the field of public administration, for example, governance has both a narrow and expansive use. In its narrow sense governance represents the task of managing networks while in its broad sense it is concerned with the process by which the rules of public policy are set. Legitimacy draws from both the output side, arising from effective performance, and the input side, arising from the democratic nature of process. At the international level, 'governance' is concerned with managing globalisation and the issue of whether or not national states can be bound by international rules. In the European context 'governance' is often used to describe multi-level governance and systems which recognise both hierarchies and networks. 
Table 6 Summarising governance theory

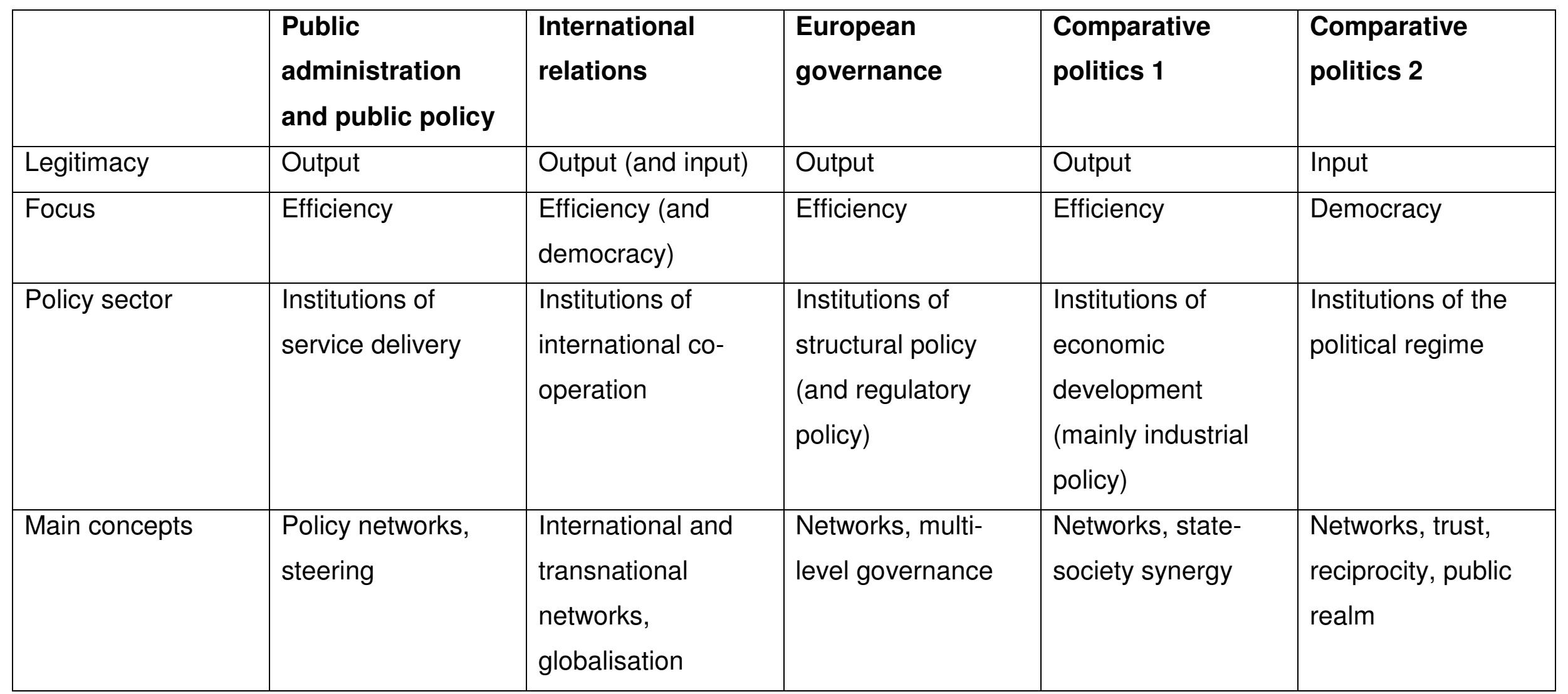


Definitions of governance vary, although two are particularly relevant to the objective of this thesis. The first is the World Bank's definition, namely "the manner in which power is exercised in the management of a country's economic and social resources for development" (World Bank 1991, p. 1). The other is the United Nations Development Programme's (UNDP's) definition, which describes governance as:

the exercise of political, economic and administrative authority to manage a nation's affairs. It is the complex mechanisms, processes and institutions through which citizens and groups articulate their interests, exercise their legal rights and obligations, and mediate their differences (UNDP 2005).

By focusing on the exercise of authority in the public interest, definitions of governance tend to be concerned with processes that extend beyond the realm of government. In fact, the concept arose partly in response to the recognition that there are a range of problems that are simply beyond the scope of governments acting by themselves. As Daniel Bell eloquently quipped more than 30 years ago, "the national state has become too small for the big problems of life, and too big for the small problems" (Bell 1973, p. xxxi). Whether the issue concerns inner city crime or climate change, solutions require the participation of multiple agencies, public as well as private, in other words effective governance. A number of writers have noted an association between 'governance' and the idea of New Public Management (NPM) (Rhodes 1997). NPM is used to describe how, in the last few decades of the 20th century, private sector approaches to management have been introduced into the public sector. These can be broken into seven distinct themes:

- rational management through strategic management

- separating policy from administration and delegating service delivery responsibilities

- individualising performance 
- applying human resource management techniques and an emphasis on the economy, efficiency and effectiveness

- focusing on consumers, customers and citizens in a way not dominated by professionals

- demand rather than supply-led organisations

- shifting to more market-focused values (Sullivan et al 2006).

Used in a public sector context, references to the governance role are frequently shorthand for the list of attributes identified above as well as making the distinction between 'steering', which involves setting direction, and 'rowing', the implementation role (Osborne and Gaebler 1992). Osborne and Gaebler's picture of governance in action envisages decentralised public agencies cooperating with business, community and voluntary groups to improve public service delivery and meet new or urgent demands, which they describe as 'steering'. In relation to this particular use of the term, more recent debate exists as to whether governance should be seen as a form of NPM or as a consequence of NPM. These commentators argue that the NPM phenomenon has become increasingly preoccupied with surveillance and regulation and that the governance paradigm is, in fact, a reaction to NPM, developed in order to be less dependent on external directives (Dent et al 2007). Other arguments similarly reinforce the reaction perspective and note that NPM emphasises efficiency and outputs, whereas governance emphasises quality of life and the application of agreed governance principles (see Bovaird and Loffler 2007). This more recent interpretation approaches governance as a response to managerialism which has resulted in diminished citizenship (Gallop 2006). Governance is regarded as a way of providing a more equitable political process which allows communities to "accommodate diverse points of views, determine collective values and create a distinct sense of locality and identity" (Marshall and Sproats 2000, p. 25).

The fact that governance has received such wide and varied interpretations has undermined its operational utility, yet despite this most definitions of governance contain the following features in common: 
- that governance involves multiple stakeholders and is frequently applied to collective problems that cannot be solved by the public sector working by itself but require the co-operation of other players (for example, citizens, business, voluntary not-for-profit sector and media)

- that governance concerns both formal rules (such as constitutions, laws and regulations) and informal rules (such as codes of ethics, customs and traditions)

- that governance focuses on market structures (as steering mechanisms), hierarchies (for example, bureaucracies) and cooperative networks (as possible structures for facilitating change in some situations) (see Loffler 2003).

Governance then is concerned with the behaviour of multiple actors. This involves the formation and stewardship of rules, both formal and informal, that control the public space in which economic and social actors interact to make decisions. This process is important. Kjaer, for example, highlights the role of negotiation as a component of governance which she describes as "the means for achieving direction, control, and co-ordination of individuals and organisations with varying degrees of autonomy to advance joint objectives" (Kjaer 2004, p. 282). Simply put, if governance involves operating across institutional boundaries then traditional coercive steering instruments will no longer suffice, requiring a new set of governing skills, skills that recognise the autonomy of agents and are more concerned with persuasion and negotiation. Governance, consequently, is not confined to the national or international sphere; it applies at all levels of public and private life, including local government and the way communities are governed.

\section{From government to governance}

The growing use of the governance lexicon has forced writers to consider its relationship to the concept of government. If governance is a wider concept than government, how do the two relate and is it a separate phenomenon from 
government or simply a particular style of government? If by its nature governance is concerned with the interplay of stakeholders seeking to exercise power over each other in order to further their own interests, then it cannot be left to purely managerialist or professional decision-making elites (see Bovaird and Loffler 2003). Logically it must represent the interplay of both governmental and non-governmental actors. Government, in contrast, reflects more standardisation and the "formal procedures and institutions societies have created to express their interests, to resolve disputes and to implement public choices" (John 2001, p. 4).

There are two senses in which governance is used in relation to public administration, narrow and broad. In the narrow sense, governance is used to describe the tasks governments face in managing networks (networks being a specific response to the reality of a more fragmented and differentiated polity). In this sense, governance describes the way governors influence or direct networks in order to ensure the implementation of policies and programmes. It involves a menu of techniques, from consensus-building to co-ordination and influencing. In contrast, when used in its broader sense governance refers to the overall process of managing the rules through which public policy occurs, as well as describing the overall co-ordination and management of not only networks but also hierarchies and markets. When used in this sense, governance encompasses the broadest range of institutions, formal and informal, as well as the shared goals of citizens.

Ultimately governance is used to emphasise the complex nature of governing in an environment in which governments cannot work alone and where policy outcomes are the result of interdependent action by a range of actors, societal as well as public. This notion of governance involves shared goals, blurred boundaries and numerous interactions and "highlights the limits to government by a central actor, claiming there is no longer a single sovereign authority" (Rhodes 1997, p. 51). In a related but diminished sense, governance is used to describe self-governing networks, the environment in which public services are provided by any combination of public, private and community providers. Such 
networks are regarded as largely self-organising and sit alongside markets and hierarchies as options for providing services.

They are not controlled by any supranational actor, not even the government. They largely control themselves ... De-regulation, government withdrawal and steering at a distance ... are all notions of less government regulation and control, which lead to more autonomy and self-governance for social institutions (Kickert, quoted in Rhodes 1997, p. 52).

These interpretations of governance highlight the involvement of state and nonstate actors and suggest "a new approach to the study of politics" (Kjaer 2004, p. 189). Some of the differences between governments as institutions and governments concerned with governance are highlighted in Table 7, which compares stereotypical local government to a similarly stereotypical notion of community governance. 
Table $7 \quad$ Characteristics of government and governance

\begin{tabular}{|l|l|}
\hline Government & Governance \\
\hline Few institutions & Many institutions \\
\hline Hierarchical structure & Decentred/fragmented \\
\hline Closed networks & Extensive networks \\
\hline Few linkages & Extensive linkages \\
\hline Representatives & $\begin{array}{l}\text { Representative plus } \\
\text { experimenting in new forms } \\
\text { of participation }\end{array}$ \\
\hline Routine policy-making & $\begin{array}{l}\text { Innovative policy-making } \\
\text { due to a greater range of } \\
\text { participants }\end{array}$ \\
\hline
\end{tabular}

(Source: adapted from John 2001)

Key differences between governance and government are the amount of formality, hierarchy, networks, linkages and innovation involved, as well as different forms of democratic participation (John 2001, Rhodes 1997, Kjaer 2004). Working in a governance environment involves working outside institutional boundaries, making less use of traditional hierarchies and command-control mechanisms and having less formality. It involves greater levels of democratic participation and engagement with policy networks than would normally occur in government, with its reliance on hierarchies and command-control methodologies. Critical are the emphasis on well-being and the recognition that this involves multi-faceted and interdependent interventions.

\section{The problem of networks}

One of the challenges facing governments that choose to take a governance approach is managing inter-organisational approaches, in which groups of public and private organisations operate in a resource-dependent manner (see Considine 2006). These cross-jurisdictional networks create unique challenges for setting direction and maintaining accountability, even though the potential for 
networks has been strengthened by the emergence of new technologies that improve communication and increase transparency. For example, technology enables different groups which are united by shared interests (as opposed to just geography) to carry out international policy-making (see Florini 2005). In fact one theorist points to a perceived erosion of state capacity (the hollowingout thesis) and argues that the rise of networks has resulted in "no centre but multiple centres (in which?) there is no sovereign authority because networks have considerable autonomy" (Rhodes 1997, p. 109). In the view of these theorists the result has limited governments to the co-ordination and steering of networks - a governance role. They argue that the mobility of capital, firms and citizens, as well as the privatisation and fragmentation of services, has restricted the range of policy tools open to governments, forcing them to adopt new approaches to governance which might not be compatible with democracy.

Despite the concern that governance may weaken democracy, promoters of government as governance argue that it allows more participation by political actors than traditional government, prompting suggestions that governance rather than government can actually strengthen democratic accountability (Kjaer 2004). For these theorists governance is seen as a way of addressing democratic deficits and loss of legitimacy which can arise when attempts to resolve complex and intractable problems fail (Giddens 2000, Gaventa 2004,). Loss of legitimacy arises when citizens perceive that governments have become unresponsive and disconnected from their citizens, leading to disillusionment with large institutions, which are likely to be regarded as "distant, unaccountable and corrupt" (Gaventa 2004, p. 17). The result of disillusionment is a democratic deficit which occurs when citizens stop taking part in democratic processes, such as voting, and no longer employ legitimate means of democratic participation (Giddens 2000).

Governance is promoted as a way of addressing such democratic deficits by providing an opportunity for a greater range of actors to take part in the policymaking and decision-making process. The virtues, however, have a down-side. While governance appears to provide new opportunities for democratic engagement outside the hierarchical structures of government, it can be 
criticised for being less transparent and less accountable. Unlike government decisions, those made in the less formal world of relationships characteristic of governance are less likely to be recorded, less likely to be subject to rules which guarantee freedom of information and absence of interest, and less accessible to the public.

The different ways in which governance is used in the academic literature highlight some common characteristics, particularly the idea that governance is a process that occurs when governments actively work to influence multiple agencies and organisations to achieve collective goals. In this conception it represents a process in which governments play a leading, but not solitary, role in the exercise of public authority and power. This is how the concept will be referenced in the remainder of the thesis and it is just as relevant to the local or community sphere as the national.

\section{Community governance}

In its most literal sense, community governance means governance exercised by communities themselves, such as community self-management or citizen governance. It is concerned with policies and practices that empower citizens to make and influence decisions that affect them and their communities (see Stewart and Clarke 1996, Richardson 1999a, Rhodes 2007). For practical purposes, governance is understood as occurring at four levels: international, national, regional, and local/community. Community governance encompasses both local and community prefixes, which are used interchangeably in the relevant literatures.

\section{Background}

The idea of community governance as a style of local government began to surface in the late 1980s as writers, particularly in Britain, began to consider the implications of public sector reform on the local state. One of the earliest references to the concept comes from Stewart and Stoker, who, writing in 1988, suggested that political and institutional change was forcing local government to become what they termed "community government" (see Rhodes 1997). For 
them, community government meant that councils formed partnerships with local citizens, with strong local accountability and responsive service delivery. It meant local government by and for the community, in which councils' primary role was to recognise issues rather than manage services; services were to be provided by independent and quasi-independent agencies, and councils were to be primarily enabling agencies. ${ }^{37}$

The concept of community government failed to find wide academic support at the time, perhaps because it failed to reflect the nature of the new relationships that were evolving and which extended beyond the traditional boundaries of 'governments'. It soon transformed into the concept of community governance. As early as 1994 Stewart and Clarke began to refer to a changing pattern of local government which could not be understood without examining the "disposition of other players in the ... wider system of community governance" (ibid, p. 201). The trigger for much of this discourse was the fragmentation that arose from the public sector restructuring undertaken by the British Conservative government of the period. Fragmentation was perhaps predictable, as the British experience of public sector reform favoured the establishment of arms'-length bodies focused on single objectives, many of them in private ownership. They included such organisations as urban development corporations; compulsorily formed local-government-owned companies such as bus companies; public-private partnerships; user organisations; intergovernmental committees; and private sector companies funded to provide public services (Rhodes 1997).

The creation of stand-alone agencies was an essential part of the United Kingdom's public sector reform initiative and, while it also occurred as a result of modernisation initiatives elsewhere, the Conservative Government was one of its loudest cheerleaders. Legislation privatised key local government functions, such as the provision of potable water, and required councils to competitively tender an increasing proportion of their activities. (Australia sought

\footnotetext{
${ }^{37}$ It is interesting that the discourse on community governance in the United Kingdom developed at the same time that local government reform, driven by the Thatcher-led Conservatives, was being described as creating an 'enabling' state. This involved the notion that councils should be concerned with enabling others, rather than doing things themselves.
} 
similar results in a less heavy-handed way through its Productivity Commission.) Reformers considered that disaggregating public services into more discrete units focused on single objectives brought a number of advantages, such as better alignment with service users, more capacity for innovation, and more accountability for performance. Single-purpose organisations were regarded as less likely to be distracted by competing objectives and, because such agencies had more freedom and clearer objectives, they could be more innovative (see Schick 2001, SSC 2001, Scott 2001).

Balancing these apparent advantages, however, were a number of problems, such as the difficulty of defining agency tasks in the face of changing needs. For example, single-purpose agencies tend to have a narrow focus and may find it difficult to refocus and adapt their services in response to rapidly changing environments. This lack of flexibility and responsiveness can be exacerbated by the trend of national governments to impose national standards, which further locks agencies into the production of a single service, less able to adapt and reflect local circumstances (see Stewart and Clarke 1994). Single-purpose agencies also tend to strengthen vertical accountabilities at the expense of horizontal ones, making it difficult to achieve a whole-of-government and placebased approach to addressing local issues. As Pierre (quoted in Stoker 2000) argues:

It is in some respects ironic that the pressures unleashed by New Management have encouraged local authorities to rethink and redefine their role. The vision of the New Management reformers aimed at more efficient and customer oriented service delivery by local authorities has been challenged by a broader vision of a new community governance (Pierre, quoted in Stoker 2000, p. 145).

In a policy environment where councils were not only encouraged, but forced, to disaggregate services and focus on a narrower range of activities, local authorities in the United Kingdom found themselves the most knowledgeable agencies in their localities, better placed to make the connections between local 
service providers than any other single organisations. It was somewhat ironic as councils, having been the target of the Government's modernisation project, also provided the solution for bringing the pieces back together. They did this by focusing on the locality as a whole, rather than specific sectors. As noted above, stand-alone agencies designed on largely managerialist principles, while more efficient in a technical sense, were found to be poorly suited for addressing issues of allocational efficiency, that is, determining the most effective mix of services. Allocational efficiency requires trade-offs involving the consideration of community values and the question arises: Which agencies are best suited to make trade-offs involving community values? The answer involves organisations which have a democratic mandate and are bound by processes that reinvent and reinforce that mandate, such as regular elections and requirements to consult. In response to the problem of fragmentation created by the United Kingdom's modernisation programme, local government offered an institutional response to the problem that could accommodate the efficiency gains of stand-alone organisations with the allocation benefit of more co-ordination and alignment.

\section{Local government's contribution}

As democratic organisations with universal franchise, councils provided an avenue for voice and choice through which local issues could be identified, aspirations recognised and diversity fostered. In addition they were still multipurpose organisations, even though many of their traditional activities had been corporatised or privatised and they had a history of taking integrated approaches to problem solving. In short, local government's key attributes for this task were seen as:

- being multi-purpose, with a wide range of functions

- having the right to tax and allocate public resources being directly controlled by elected representatives

- having the right and responsibility to speak out on issues of concern to its area (Stewart and Clarke 1994). 
In the United Kingdom councils began to undertake the role through necessity, despite financial constraints created by reduced funding, competitive tendering and more prescriptive performance measures (Stoker 2000). The role had an inherent focus on community leadership, which was picked up and reinforced by New Labour after its election in 1997 (see DETR 1998). The new focus on leadership added a dimension to the argument in support of a broader governance role for local authorities. One of the argued advantages of such decision-making systems, which might be described as governance as opposed to traditional governmental approaches, is their better capacity for dealing with an emerging range of very difficult problems commonly referred to as "wicked issues". ${ }^{38}$ These are issues that Roberts (2000) argues have the following characteristics:

- There is no definitive statement of the problem (and there may be disagreement on the nature of the problem).

- Without a definition the search for solutions is open ended, with a tendency for people to frame "problems" to better connect with their preferred solutions.

- The problem-solving process is complex because constraints, such as resources and political ramifications, are constantly changing.

- Constraints change, because they are generated by numerous interested parties which selectively choose to share information and may change the rules by which the problem must be solved.

In summary, these are problems about which there is a lack of consensus with regard to their definition, the prevailing rules and processes by which they should be solved, and a lack of clarity with regard to available resources for addressing them. Traditional linear problem-solving techniques, that is, scope the problem, undertake research and develop options, are no longer regarded as sufficient or successful. Roberts speculates that recent interest in the idea of wicked problems may have to do with the technological and information revolutions and the increasing diversity of society, with corresponding less

${ }^{38}$ The Germans refer to these as "malignant problems" (see Naschold 1997). 
homogeneity of values. Addressing wicked issues involves collaborative forms of working as "we learn to take care in attempting to tame wicked problems by turning them over to experts or some centre of power for definition and solution" (Roberts 2000, p. 16). Solving these problems appears to require a process of social learning, through self-organising, complex and adaptive systems, that coevolves as stakeholders interact and inform on another's actions. Problems and issues frequently referred to as "wicked" include climate change, unemployment and family violence.

\section{Defining community governance}

The emergence of a group of theories which treated local government as a form of community governance signalled a shift in thinking from a focus on governing organisations to governing communities, not necessarily defined within historical boundaries or service delivery jurisdictions (Stewart and Clarke 1996). It represented a change in emphasis for local authorities in that it encouraged them to think about the well-being of their community rather than the traditional practice of focusing on the delivery of a prescribed number of local public goods. While implying that councils had previously turned a blind eye to the welfare of their citizens by focusing on outcomes rather than the efficient delivery of services, a new dynamic in the governing process is created, a process that requires an additional set of skills and competencies to those traditionally held and practised by councils (see Table 8 ). 
Table 8 From local government to community governance

\begin{tabular}{|l|l|l|l|}
\hline & Focus & Orientation & Technique \\
\hline $\begin{array}{l}\text { Local } \\
\text { government }\end{array}$ & $\begin{array}{l}\text { Delivery of } \\
\text { services } \\
\text { addressing social } \\
\text { problems, } \\
\text { regarded as } \\
\text { separate and } \\
\text { discrete }\end{array}$ & $\begin{array}{l}\text { Unilateral } \\
\text { interventions by } \\
\text { single agencies }\end{array}$ & $\begin{array}{l}\text { Rigid dependence on } \\
\text { hierarchical/bureaucratic } \\
\text { or (quasi) market } \\
\text { mechanisms }\end{array}$ \\
\hline $\begin{array}{l}\text { Community } \\
\text { governance }\end{array}$ & $\begin{array}{l}\text { Managing the } \\
\text { problems of } \\
\text { citizens' well- } \\
\text { being', regarded } \\
\text { as multi-faceted } \\
\text { and } \\
\text { interdependent }\end{array}$ & $\begin{array}{l}\text { Multi-lateral } \\
\text { interventions by } \\
\text { public-private } \\
\text { partnerships }\end{array}$ & $\begin{array}{l}\text { Flexible deployment of } \\
\text { bureaucratic (quasi) } \\
\text { markets and networking } \\
\text { mechanisms }\end{array}$ \\
\hline
\end{tabular}

(Source: Kjaer 2004, p. 38)

The differences between local government and community governance can be approached along three dimensions - focus, orientation and technique. As Table 8 describes, councils that have adopted a community governance orientation focus on the broad concept of citizens' well-being rather than limiting their focus to the provision of discrete services. This requires that councils take an interest in the outcomes created by other service providers, whether they are central government, a higher tier of government or another sector altogether. Given that the well-being is multi-faceted, and characterised by interdependencies, strategies to enhance it will need to be similarly approached and involve greater use of partnerships and other forms of collaboration, particularly multi-lateral interventions (Kjaer 2004). In the United Kingdom, for example, the government has introduced the concept of Local Area Agreements (LAAs) to provide a mechanism for agencies to align their services with local 
outcomes. In another example, Kjaer (2004) cites British research on social housing which shows that councils have moved from traditional bilateral approaches to housing provision to approaches that are multilateral, involving multiple agencies. Similarly, the way councils deal with crime has shifted from a focus on individual criminals to multi-agency partnerships focused on problems of community safety. Perhaps the most visible change concerns the issue of technique. Councils that adopt a community governance approach will need to learn to work in an environment which is less hierarchical than they are used to. This has implications for the competencies and skills of both elected members and their officials involving greater use of facilitation, mediation and convening competencies. It also changes the nature of leadership.

Local governments that exercise community governance operate in such a way that they break down the bureaucratic and organisational boundaries between themselves as institutions and the multiplicity of organisations, agencies and citizen groups that make up their communities. These are councils which:

- focus on outcomes for the complete jurisdiction over which the authority has responsibility

- reflect a commitment to steering the multiple organisations that contribute towards the achievement of those outcomes and take participatory and inclusive approaches to decision-making

- have a willingness to take on roles other than that of service provider, such as convenor, leader or facilitator.

In short, councils that practise community governance are more concerned with securing the outcomes desired by their citizens than the delivery of specified outputs. This involves working outside their institutional boundaries and forming partnerships with central government agencies and other organisations, where these can address local problems and consciously seek to enhance citizen engagement. An important aspect of this style of operation is an agreed vision or sense of direction. 
Organisational leadership is concerned with the culture, direction and performance of an organisation and its efficacy at fulfilling its purpose. Leadership under a community governance framework operates beyond the confines of a single organisation, an environment in which authority is more symbolic than legislated. In this approach the purely representative model of local democracy is combined with more participatory techniques to secure community buy-in to the goals sought by the local authority, goals which are largely dictated by citizens working with their councils. This also involves attempting to align their services with the services of other organisations in order to achieve outcomes (see Stewart and Clarke 1996).

After beginning as a necessary response to fragmentation at the local level community governance came to be seen not only as instrumental in dealing with the effect of public sector reform but also as desirable in itself. Stewart and Clarke (1996) articulate this more positive view of community governance as improving co-ordination and aligning public service providers and thus revitalising local democracy. They argue that local authorities, as the form of elected authority closest to citizens, should be primarily responsible for community governance and contend that councils' democratic mandate gives them a historical responsibility to legitimise the actions and decisions of other agencies and organisations. In order to achieve this, they emphasise councils' role in providing voice and a process of local accountability.

\section{The literature on local government and community governance}

Much of the discussion on community governance reflects a strong indebtedness to the experience of the United Kingdom (see Rhodes 1997, Stoker 2000, Stewart and Clarke 1994). However, it begs the question whether or not these experiences can be generalised outside a British context. Is community governance a bona fide new model of local government or is it simply a necessary survival strategy adopted by councils in the United Kingdom to deal with a relatively unique set of challenges? Is community governance a new fashion contingent on the particular government in power? 
Community governance encompasses a range of related theories about local government, connected by the way in which they approach key concepts, such as leadership and engagement. This can be approached as a family of related theories (see Figure 3), most of which have emerged in the last few decades and build on the critiques developed by the early community governance advocates, such as Rhodes and Stewart and Clarke. These new theories of local governance are a combination of ex post rationalising of institutional and policy shifts associated with public sector reform and normative theories, designed to promote particular value propositions. Common features are identified which are then used in the development of the assessment model (see Chapter 3).

Figure 3 A family of community governance theories

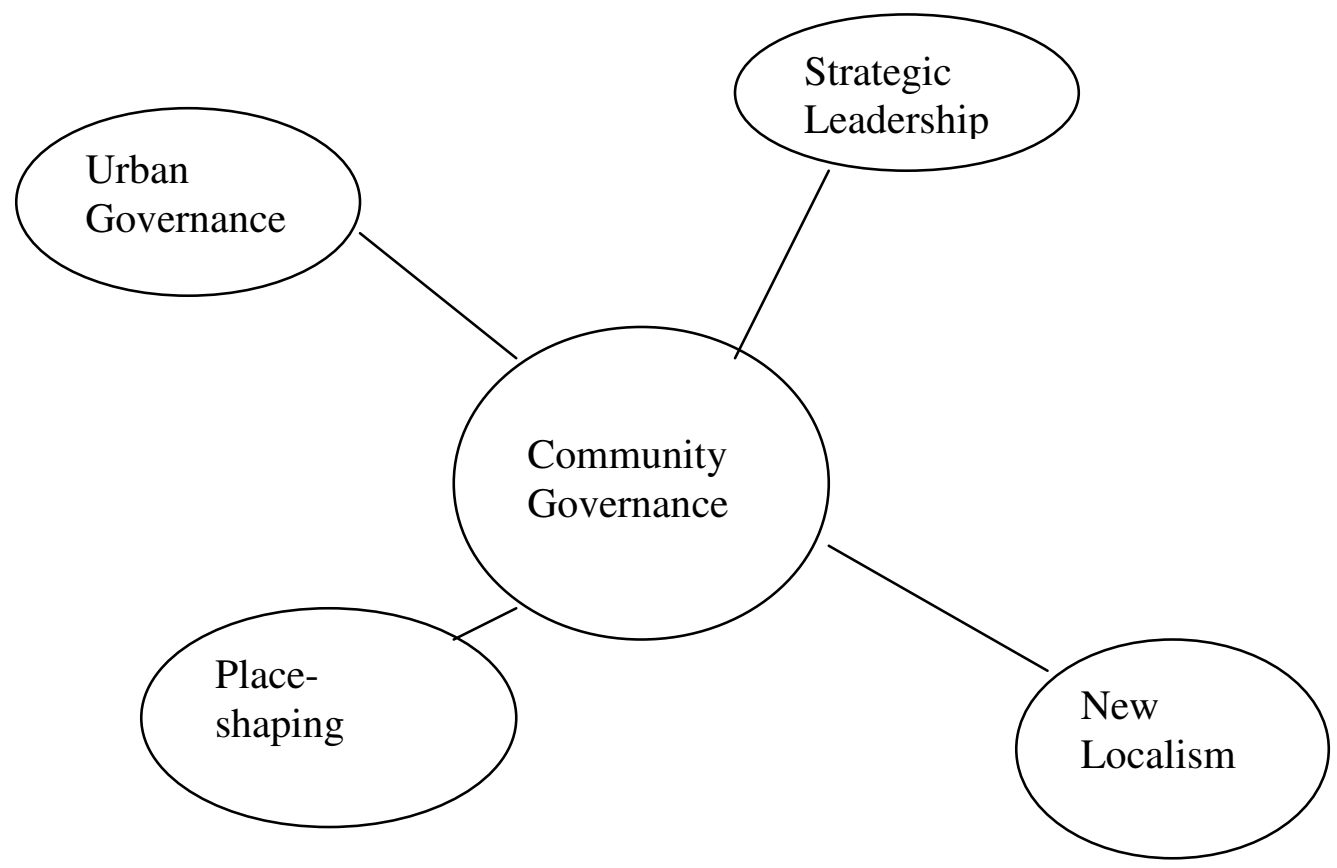

\section{Urban governance}

From its emergence in the fragmented localities of late 20th century Britain, the literature on community governance has moved from being largely reactive and problem-focused to proactive and opportunity-focused. This is also reflected in the literature on urban or metropolitan governance. Gootman (1998) argues that 
the concept of metropolitan governance arose in response to increasing fragmentation of metropolitan regions, particularly in the United States, where there is little public acceptance of top-down consolidation measures found in places like the United Kingdom and New Zealand. ${ }^{39}$ According to the National League of Cities in the United States, metropolitan governance encompasses: (1) all community interests affected by challenges and necessary to their resolution, not just government institutions, and (2) the collaborative problemsolving mechanisms needed to design timely strategies as well as the government institutions and other service delivery mechanisms needed to implement them (see Gootman 1998). These are collaborative arrangements through which councils and non-council actors actually exercise city authority (Matkin and Frederickson 2009).

Underpinning much of the urban governance literature is a view of cities as centres of innovation and growth, such as the recent focus on the ability of cities to attract the creative class, which is viewed as a generator of innovation (Florida 2002). To achieve this, policy-makers have been forced to consider how to empower councils to participate in effective city governance and to ensure that well-run cities contribute to the achievement of national economic and social goals. This objective is often framed in terms of well-being or good governance of the locality, and policy-makers have been experimenting with legislative frameworks to allow not only the provision of appropriate local public services but also new approaches to sub-national governing. The concept is captured in the concept of the entrepreneurial city which is:

a proactive city which aims to mobilise social, political and economic resources in a coherent institutional framework to develop - and sustain long term support for - a clear social and economic development strategy (OECD 2000, p. 3).

\footnotetext{
${ }^{39}$ In both countries, central government imposed consolidation or amalgamation programmes without questioning to any extent the right of central government to impose such programmes. Both the constitution and public views with regard to the limits of government would make such interventions highly unlikely in the United States.
} 
The rise of urban theory is ultimately associated with the growth of urbanisation and recognition that metropolitan areas have become the engines of prosperity and "drivers of environmental sustainability and social progress" (Katz 2007, p. 1). Urban governance theorists are not only concerned with raising the recognition of urban issues in higher level governments but also with ensuring urban governments, that is councils, have the policy tools and institutional levers to promote innovation and growth while operating within defined ecological footprints and providing for citizen participation and autonomy. Such measures tend to be characterised by a preference for more independent local polities, greater decentralisation, more use of networks and the creation of an urban strategic capacity. As Coaffee notes:

centralised power and bureaucracy is morphing, albeit slowly, into a system of greater decentralised decision-making, collaboration between service sectors and wider participatory structures. This has been related to wider transformative processes that have sought to refashion and recast the political and managerial linkages between national, regional/provincial and local states. Furthermore, such processes have increasingly attempted to draw the private sector and local communities into decision-making processes about creating sustainable neighbourhoods, cities and regions (Coaffee 2005, p. 108).

Urban governance contributes to the overall conceptualisation of community governance by its emphasis on place and the necessary relationships that are required for a city to prosper. This involves an aggregation of interests, not only as individuals but of the plurality of collective interests, from business to the non-governmental sector, frequently captured in support for city development strategies recommended by the World Bank in its work on urban and local government strategy (World Bank 2000). Such strategies mobilise "city stakeholders to identify local strengths, bottlenecks, and market opportunities and to commit to appropriate joint actions" (ibid, p. 49). City strategies can be understood as a process of local or community strategic planning, involving participation by all city stakeholders, such as firms, workers, officials, financiers, voluntary organisations, universities, research centres and infrastructure 
providers. Apart from identifying impediments to development, participants are expected to articulate their contributions to the process.

This new art of governing involves cities which have adopted and adapted the tools of the corporate world to maximise their competitiveness (Katz 2007). It is strongly strategic, requiring cities to diagnose the context in which they operate, explore the dynamics of their urban demographics and economies, and understand their assets and liabilities (ibid). In the view of its advocates, councils embracing the new art of governing focus on both the "soft and hard infrastructures and services that help to make a competitive environment for firms, and an attractive place to live for their employees" (Gurria 2007, p. 1).

\section{Local government as strategic leaders}

The concept of urban governance and community governance in general posits a different approach to the role of local government, an approach which places as much emphasis on councils' roles in their social and economic environments as it does on their roles as providers of local services. Advocates for this view tend to highlight issues of globalisation and the ease by which capital and skilled labour shift between places and across state boundaries (see Albrechts 1991), changing production practices and citizens' expectations of having a greater say in the way in which their communities operate. ${ }^{40}$ Critical to considering the role of local government in these processes is the concept of leadership as noted by Hambleton (2008) in his work on urban governance:

The legitimacy needed to exercise bold and effective metropolitan leadership in modern times is likely to flow from an approach that combines multiple actors drawn from local government and civil society, from the public, private and non-profit sectors (Hambleton 2008, p. 18).

Hambleton's work disaggregates the notion of civic leadership into a number of overlapping roles: political leadership, managerial leadership and community leadership. Political leadership describes the role mayors and senior politicians

\footnotetext{
${ }^{40}$ This creates a paradox, given that participation in traditional and formal democratic processes, such as voting, is declining (see Giddens 1999).
} 
play in leading the elected arm of councils. Managerial leadership deals with the role of civil servants within local government while community leadership highlights the leadership roles played by other parties in civic society, such as business organisations. This is outlined in Figure 4.

Figure 4 Civic leadership

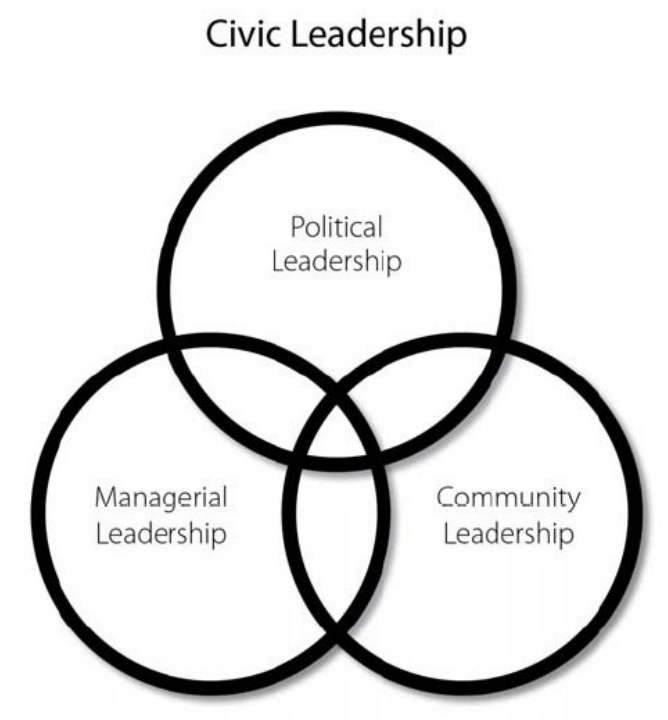

(Royal Commission on Auckland Governance 2008, p. 523)

In Hambleton's view local leadership requires councils to provide a focal point for the development of a collective vision for the future that reflects local priorities and brings together key agencies to achieve it. This requires strong democratic accountability, a clear sense of place (to the effect that participants recognise that they are part of the same community of interest) and a capacity to bring the groups of local organisations and agencies together. Hambleton notes that in any given city there will be a pattern of dispersed leadership and that power is likely to be fragmented in conditions of social complexity. Civic leadership, as a whole, involves connecting the fragments and occurs when "a compelling vision emerges from an inclusive process and is then articulated by a leader or leaders"; "the results are inspiring" (ibid, p. 33).

The concept of governance is inherently concerned with leadership and new forms of governance are likely to involve new forms of leadership, so as to 
mobilise local stakeholders. Reflecting this Hambleton (2008) notes that some councils have redefined local leadership by replacing hierarchical approaches with partnerships and adopting a collaborative towards achieving common goals. Such councils tend to display the following characteristics. They:

- articulate a clear vision for their areas

- promote the qualities of their areas

- win resources

- develop partnerships

- $\quad$ are prepared to work on complex issues

- maintain support and cohesion (Hambleton 2008).

Governance theorists consider that this collaborative model of leadership represents a necessary response to the shortcomings of traditional forms of public authority by focusing attention on community priorities and galvanising various actors to contribute to delivering them, with the active participation of local citizens (see Sullivan 2008). In this view effective local leadership must involve an ability to mobilise local actors and agencies and work in partnerships. Gallop (2006), for example, argues that government needs to be more strategic in order to promote more collaboration between levels of government and their communities. In his view strategic government is the governance paradigm of the 21 st century and is necessary to address problems created by public sector reform that made whole-of-government responses to issues more difficult. It is a justification based on the view that suggests citizens are demanding a more collective approach to the activities of government in order to address issues such as crime, anti-social behaviour, drugs, alcohol and social dysfunction (the wicked issues?).

More recent interpretations of community governance, such as Gallop's, tend to place emphasis on policy initiatives of the community-strengthening type, that is, "stronger forms of local connectedness and better linkages between government and other agencies to mobilise local assets" (Considine 2006, p. 2). The concept has four dimensions: increased connectedness, distributed 
leadership, inclusive partnerships, and new governance institutions. A critical factor underpinning them is the manner in which public agencies, citizens and excluded groups contribute to the process of determining priorities and coordinating services, reflecting a move away from "older models of hierarchical co-ordination to experimental new forms" (Considine and Giguere 2008, p. 258). These new policies are also characterised by a territorial focus rather than a focus on specific sectors or policy subjects.

\section{New localism}

Community governance is inherently local and interest in promoting it as a legitimate governance option is reflected in the increasing importance given to the connection between the governance of places and economic performance (see the report of the Royal Commission on the Governance of Auckland 2009). A pertinent theory is new localism. Initially promoted by the New Local Government Network, a United Kingdom think-tank, it has now become widely recognised in the mainstream local government policy debates (see Filkin et al 2000). ${ }^{41}$ New localism combines the political insights of traditional localism, a belief that all government activity should be as local as possible, with the techniques and lessons of recent public sector reform. As a concept it draws on theories of devolution seeking to have more responsibilities located with local government; but it also seeks organisational forms designed to address the parochialism and lack of capacity which plagued traditional localism. In bringing localism to a modern audience it promotes a collaborative response to the problems confronting communities, such as the use of strategic local partnerships and, the development of city-regions and mandatory strategic planning. New localists take as read much of the modernist agenda and envisage a form of local government that is less defined by its capacity as agent and more by its capacity to "win the approval of local people and stakeholders for its problem-solving, vision and expression of their interest" (Filkin et al 2000, p. 11).

\footnotetext{
${ }^{41}$ For example, the Conservative Party's Green Paper, Control Shift: Returning Power to Local Communities (Cameron 2009), criticises what they describe as the government's lip service to localism, and recommends a localism where power is shared and communities are once again trusted.
} 
New localism attempts to put a modern spin on traditional localism and the view that small is always best. It does this by emphasising the role of leadership which transcends organisational leadership to be concerned with places, as well as by acknowledging the need to operate within a minimal framework of national standards. New localists seek to marry the concepts of devolution and decentralisation with a broader framework of public sector reform in order to prevent local authorities becoming small versions of the bureaucratic state. In this sense new localists share an affinity with writers, such as Bryson (2004), who posit a view of the world in which the binary distinctions between the domestic and international spheres, between local and central government, and between the government and private/voluntary-sector actors are blurred. This is well illustrated in their view of local leadership, according to which the local authority will:

be concerned with everything that affects the public in the locality, whoever is responsible for it and will work with the public as individuals or in local organisations to champion and achieve change that is desired by local people (Filkin et al 2000, p. 6).

For new localists, leadership involves a dynamic and strategic conception of local governance, which requires local authorities to do more than simply follow the community's preferences. Their approach to leadership reveals an indebtedness to theories of community governance as it involves developing and communicating visions in order to bring together and co-ordinate multiple agencies. While new localism has had a strong influence in the way in which the government and opposition parties in the United Kingdom have begun to think about local government (parties are literally competing in the media to show how their local government policies reflect new localist principles such as greater devolution) it is also consistent with the earlier work of community governance theorists (see Stewart and Clarke 1996). The key features of councils that adopt a new localist agenda are a commitment to:

- working with others to determine what needs to change in the locality

- promoting a consensual approach to developing a strategic vision 
- developing a practical strategy to realise the vision and promote the realisation of this strategy locally and to central government

- acting as a broker between agencies

- acting as strategic commissioners, free from vested interests

- presenting themselves convincingly as guardians of the public interest

- taking the tough decision that no-one else will (ibid).

The idea that the local authority is part of the community and also has a role in how it is shaped is reflected in two related concepts, co-operative communities and partnership governance. Both reflect a concern that competition between governments has reduced citizenship rights, increased inequality, transferred decision-making to semi-private networks, such as public private partnerships, and resulted in a diminution of the public space traditionally occupied by local government, a trend that can only be reversed if councils act like co-operative communities (Warner 2001). ${ }^{42}$ Co-operative communities arise when councils build social capital by sharing autonomy with citizens and acting as catalysts, convenors and facilitators (ibid). ${ }^{43}$ This theory recognises community-building as a fundamental public good, promotes new forms of participation by citizens and non-citizens as well as moving beyond market models for the delivery of public goods. Operating councils as co-operative communities involves balancing economic and social goals, creating new spaces for innovation and democratic engagement, and focusing on physical and social infrastructure in order to provide a stabilising force in a constantly changing world. The concept of 'partnership governance' (Skelcher et al 2004) is similar, as it also argues for the involvement of a wider range of community actors in public decision-making. It involves a new way of thinking about society, one that begins with the multiplicity of communities, namely:

\footnotetext{
${ }^{42}$ Deliberative democracy is a form of decision-making in which participants are encouraged to see all sides of an issue before arriving at a decision.

${ }^{43}$ Local Government, Serving Citizens in a Competitive World, presentation to the Local Government Conference, Wellington, 2006.
} 
self-reliant communities of place and interest, where co-operation rather than competition contributes to consensually set social values and goals (where) local communities collectively identify impediments to a better quality of life that is defined in contextual terms and work together to construct the space for creating long-term sustainable solutions (Skelcher et al 2004, p. 9).

In this model of council as a type of community, the role of government is to provide the platform on which citizens can set consensual goals and essentially construct a model of governance which meets their own long-term needs, a concept consistent with a community governance approach.

\section{Local government as 'place-shapers'}

The Lyons Inquiry into Local Government Funding (Lyons 2007), which was commissioned by the British Government in 2004, endorsed in its report much of the new localist and community governance agenda. The purpose of the inquiry was to consider the case for changes to the system of local government funding in the United Kingdom and to make recommendations. However, during its work it was realised that funding could not be treated in isolation from the broader question of the role and function of local government and its terms of reference were extended accordingly. They included the strategic role of local government, the government's devolution and decentralisation agenda, and its desire for greater responsiveness to citizens. The report provides a comprehensive vision of local government, which it describes as 'placeshaping'.

While the inquiry's full recommendations on funding have not been officially endorsed, its work on the overall role and purpose of local government has been influential in recent policy debate, with both government and nongovernmental agencies drawing widely on its recommendations. Sir Michael Lyons, the report's author, argues that local government should occupy a central and leading role in local communities beyond its traditional role in the provision of local services. How this should happen, he argues, will depend on the interactions between council leaders and local citizens. Lyons calls for 
strong local communities, an explicit vision, and inclusive decision-making, and talks about communities of place and communities within council jurisdictions. Place-shaping, the big idea of the Lyons Report, is described as the "creative use of powers to promote the general well-being of a community and its citizens" (Lyons 2007, p. 60) and its key features are listed as:

- building and shaping local identity

- representing the community, including in discussions with higher levels of government

- regulating harmful behaviours

- maintaining the cohesiveness of the community and ensuring marginalised voices are heard

- helping to resolve disagreements, especially over prioritising resources

- making the local economy successful to support the creation of new businesses

- understanding local needs and preferences

- $\quad$ working with other bodies to respond to complex challenges (ibid, p. $62)$.

The idea of place-shaping is based on two assumptions. The first is that local authorities should have a role in influencing services used by local people, regardless of the formal arrangements for the management of those services. And the second is that councils are in a unique position to promote the participation of citizens, communities and service users in the co-production of services and outcomes, such as partnerships with community organisations. Lyons' view of strategy as extending beyond the organisation into the community is consistent with the approach to community governance promoted by Stewart and Clarke more than a decade earlier. Like them he believes that councils' democratic mandate provides them with facilitative and enabling roles through which they are ideally placed to lead a process of community strategising. Pre-empting potential criticism that this degree of devolution would 
lead to England becoming a 'post code lottery', Lyons argues for 'managed difference' - the idea that communities should be able to set various standards for services above national guaranteed minimums (Lyons 2007).

\section{Key attributes of community governance theories}

The previous discussion, which places the concept of community governance in a broader conversation of ideas, highlights the degree to which different conceptions of governance share a number of common features. These are summarised in Table 9.

Table $9 \quad$ Key attributes of local governance theories

\begin{tabular}{|l|l|l|l|}
\hline Concept/Theory & \multicolumn{3}{|c|}{ Attributes } \\
\hline Urban governance & Strategic & Inclusive & Devolution \\
\hline $\begin{array}{l}\text { Strategic } \\
\text { leadership }\end{array}$ & Vision & Partnerships & Legitimacy \\
\hline New localism & Leadership & Shared vision & $\begin{array}{l}\text { Community } \\
\text { broker }\end{array}$ \\
\hline Place-shaping & $\begin{array}{l}\text { Shaping local } \\
\text { identity }\end{array}$ & Cohesiveness & $\begin{array}{l}\text { Working with } \\
\text { others }\end{array}$ \\
\hline
\end{tabular}

Common attributes involve a focus on citizens and communities, multiple roles played by councils, inter-agency collaboration, strategic or long-term thinking, the creation of community visions, and inclusiveness. It has a strong localist orientation, which is designed to strengthen local voice and adopt a locally specific or place-based approach to priority setting and planning. Yet such policy settings create tension with egalitarian concerns about the national distribution of public investment and the degree to which national standards should be achieved (see Lyons 2007 and his discussion of post code lotteries). For national policy-makers a balance must be found between empowering localities to innovate while still ensuring citizens have access to the same or a similar range of services. While community governance theory is silent on these questions, it does reflect a strong preference for collaborative approaches at a local level justified by the argument that many of the issues facing communities, such as crime and disorder, cannot be solved at the national level alone. 
In its initial phase, community governance theory was developed to explain changes in council behaviour as they adapted to the first stages of public sector modernisation in the United Kingdom, particularly fragmentation. In its more recent phases, however, community governance theory has become more normative, offering an alternative institutional and methodological approach to complement traditional forms of local government. In this form community governance theory is less concerned with issues of size, function, efficiency or rights than local government theory. In contrast, it tends to focus on interagency relationships and networks as a way of developing local solutions to institutional problems. It is, in a broad sense, a post-modern theory of local government, designed to operate within the 'soft' boundaries of the new globalised social order, an environment which is constantly changing and evolving (Bogason 2001).

\section{Conclusion}

As an institutional response to changing socio-economic conditions, community governance is often viewed as an "authentic, interactive localism speaking truth to the power of globalisation" (Considine 2006, p. 3). This involves institutional arrangements that allow policies and programmes to be tailored to address uncertainties and diversity, something that is difficult for central planners or national policy-makers to do. Community governance, it is argued, enables councils to address issues of fragmentation and strengthens the ability of communities to compete in an increasingly global environment characterised by placeless power and powerless places in which geographical communities are competing to attract mobile capital (Albrechts 1991).

Yet the traditional concerns of councils have not really changed. Drinking water still needs to be provided, the rubbish still needs to be collected and councils continue to impose regulations on citizens' behaviour. In this sense community governance is an 'add-on', a set of complementary roles that use local government's democratic mandate and leadership position to advance progress towards various outcomes. It has also become a useful 'catch-all' to describe a 
style of governing that has not yet been developed into a fully fledged, coherent theory. However, as a vision which might describe a necessary or desirable approach to local government, community governance and its implementation are typically fraught and require that a range of competing elements be balanced. For example, integrated approaches to addressing local issues involving greater use of local networks (usually of officials) sits uneasily with the objective of achieving a more democratic local polity in which citizens have more say about what officials do. The next chapter draws on the common features identified in community governance-related theories and develops a series of community governance principles, which are then employed in the assessment model used in Chapter 7 to assess the potential strength of community governance in the New Zealand model. 


\section{Chapter 3 Community governance principles}

This chapter builds on the theory discussed in the previous chapter. In particular it develops a series of governance principles and a model for assessing the capacity of the New Zealand system to adopt a community governance approach.

A number of community governance theorists have sought to identify the principles underlying community governance. For example, Stewart and Clarke (1996), whose work is described in the previous chapter, have developed a concise statement of principles, namely leadership, partnership, monitoring, advocacy, responsiveness, balance (reflecting diversity), and empowerment. In their view effective community governance reflects an ability to balance each of these roles, particularly roles concerned with the macro-level issues of the area as a whole and the micro-level particularities of neighbourhoods, including relationships within the city/district. Their approach is consistent with the conclusions of a study undertaken by the Bertelsmann Stiftung (2001), which, drawing on a longitudinal study of 12 cities, identified six local governance principles. ${ }^{44}$ In the view of the foundation, community governance involves:

- strategic planning - the process of shaping the future and negotiating mutual policy goals and priorities with citizens and stakeholders

- partnering and participation - involving collaboration with citizens and government and non-government agencies, within and beyond municipal boundaries (horizontal and vertical co-ordination)

- effective and efficient administration

- the articulation of mutual policy goals and provision of appropriate information to measure progress towards outcomes

- participation by citizens in setting budgets and priorities along with synergies between public and private funding

\footnotetext{
${ }^{44}$ Cities of Tomorrow - International Network for Better Local Government. At least two of the officials who took part in the policy development phase of the LGA 2002 were associated with the Bertelsmann study.
} 
- innovation and mutual learning through benchmarking and networking (nationally and internationally).

Principles of this sort have become almost generic in the community governance literature and the OECD (2000) has recommended a very similar set, namely:

- increasing democratic legitimacy and accountability through directly elected mayors

- stronger political leadership and modernised voting procedures

- new forms of citizen participation in decision-making

- better frameworks for long-term strategic planning

- the use of integrated multi-sectoral partnerships (OECD 2000, p.6).

The themes of collaboration, citizen participation and strategic frameworks make a strong appearance, as they also did following the Rio Declaration in 1992 and, eventually, the articulation of Local Agenda 21 (LA21). LA21 was set up as a locally focused programme which sought to encourage local authorities to co-ordinate agencies to create sustainable communities. It has its origins in chapter 28 of the Rio Declaration, ${ }^{45}$ which describes local authorities as representing the sphere of governance closest to the people and called upon them to consult their communities and develop and implement local plans for sustainability. ${ }^{46}$ Collaborative and integrative planning toward specified outcomes was the essence of LA21 strategies. This was reflected in the catchphrase 'think globally and act locally', which highlighted the need for groups of citizens to take action to shape their world at the level of society that they can realistically expect to influence - neighbourhoods, towns and cities. It also focused attention on the potential of sub-national governments to contribute to national and international goals.

\footnotetext{
${ }^{45}$ See www.unep.org/Documents.Multilingual/Default.asp?DocumentID=78\&ArticleID=1163 for a copy of the declaration.

${ }^{46}$ While the uptake of LA 21 in New Zealand was less than that in countries where governments provided financial incentives to participate, city councils such as Hamilton and Waitakere were early adopters and their experiences were to influence the shape of the LGA 2002.
} 
Such sentiments also began to influence government policy-making internationally, particularly in the United Kingdom, in which much of the community governance discourse has its origins (Rhodes 1997, Stewart and Clarke 1996). In a think-piece on the role of local government entitled Vibrant Local Leadership (Office of the Deputy Prime Minister 2005), the British Government suggested that the core attributes or principles of the new governance in local government should be:

- visible and accountable leadership

- a vehicle for partnership, working and bringing key stakeholders together to work collectively to solve local problems

- efficient, effective and transparent decision-making

- strong and effective scrutiny

- coverage of the whole council area

- arrangements that are inclusive of all communities

- encouragement to people from all sections of the community to play key roles

- a clear and effective neighbourhood dimension

- the support of local people and stakeholders

Throughout the vision painted in Vibrant Local Leadership are some key community governance ideas, such as the emphasis on visible leadership; partnership working; coverage of the whole council area; inclusiveness; and a neighbourhood dimension. They are concepts that are consistent to most frameworks, particularly the importance of local government's leadership role, which is seen as not only encompassing the role of champion for its area but also one of challenging and scrutinising services provided by other public agencies to ensure they meet the needs of citizens and users. This is a view also reflected in the work of theorists like Considine (2006), who emphasise the important role councils can take in developing community strategies that set out a vision for bringing together local communities and organisations. 


\section{Principles: local government and community governance}

There is a potential symmetry between the principles of (good) local government and the principles of community governance. However there are some differences in emphasis, to the degree that the principles of local government are more focused on organisational matters than the external environment. They also emphasise the citizen as a user of council services rather than a member of a multiplicity of communities. Table 10 provides a typical example of local government principles.

Table 10 Principles of effective local government

\begin{tabular}{|l|l|}
\hline \multicolumn{1}{|c|}{ Principle } & \multicolumn{1}{|c|}{ Explanation } \\
\hline Democracy & $\begin{array}{l}\text { Citizens have the right to elect local authorities under } \\
\text { conditions of political freedom and universal suffrage. }\end{array}$ \\
\hline Legal protection & $\begin{array}{l}\text { Local authorities should operate within a legal or } \\
\text { constitutional framework that protects against arbitrary } \\
\text { intervention or dismissal by higher authorities. }\end{array}$ \\
\hline Autonomy & $\begin{array}{l}\text { Primary accountability should be to citizens and councils } \\
\text { should be able to make local laws. }\end{array}$ \\
\hline Leadership & $\begin{array}{l}\text { Legislation should enable strong leadership while } \\
\text { requiring councils to adopt clear strategic direction. }\end{array}$ \\
\hline Simplicity & $\begin{array}{l}\text { Legislation should be easy to read and systems of local } \\
\text { government should avoid unnecessary complexity and } \\
\text { layers of local government. }\end{array}$ \\
\hline Clarity & $\begin{array}{l}\text { Legislation should clearly state the purpose and mandate } \\
\text { (powers and responsibilities). }\end{array}$ \\
\hline Sufficiency & $\begin{array}{l}\text { Councils should have access to the revenue-raising } \\
\text { powers and financial resources sufficient to meet their } \\
\text { responsibilities. }\end{array}$ \\
\hline Eqffectiveness & $\begin{array}{l}\text { Local government should be expected to operate } \\
\text { efficiently and effectively and provide quality services } \\
\text { through sound planning and management. }\end{array}$ \\
The distribution of services should reflect the diverse \\
\hline
\end{tabular}




\begin{tabular}{|c|c|}
\hline & needs of the local community. \\
\hline Support & $\begin{array}{l}\text { Central government should ensure that investment is } \\
\text { made in capacity-building and advice particularly when } \\
\text { new functions are transferred to local authorities. }\end{array}$ \\
\hline Oversight & $\begin{array}{l}\text { Local authorities should be subject to the same oversight } \\
\text { and monitoring as applies to other public institutions, such } \\
\text { as independent audits, Ombudsman's Office. }\end{array}$ \\
\hline $\begin{array}{l}\text { Representative- } \\
\text { ness }\end{array}$ & $\begin{array}{l}\text { Electoral systems should ensure as far as possible that } \\
\text { councillors represent all sectors of society, in particular } \\
\text { women, youth and the disadvantaged. }\end{array}$ \\
\hline Transparency & $\begin{array}{l}\text { Procedures for council meetings should be clearly defined } \\
\text { and the decision-making process should be transparent } \\
\text { and open. }\end{array}$ \\
\hline Probity & $\begin{array}{l}\text { Codes of conduct should be enforced to prevent } \\
\text { corruption or undue influence in decision-making. }\end{array}$ \\
\hline Participation & $\begin{array}{l}\text { Councils should be required to consult local communities } \\
\text { on key issues and to formally consider submissions and } \\
\text { feedback received. }\end{array}$ \\
\hline Networking & $\begin{array}{l}\text { Structures and processes should enable active sharing of } \\
\text { knowledge and resources between local governments. }\end{array}$ \\
\hline Partnerships & $\begin{array}{l}\text { Legislation should enable local partnerships for planning } \\
\text { and service delivery between councils, other government } \\
\text { agencies, civil society and the private sector. }\end{array}$ \\
\hline Dialogue & $\begin{array}{l}\text { Formal mechanisms should be established for regular } \\
\text { policy dialogue between local and central governments, } \\
\text { particularly concerning roles and functions. }\end{array}$ \\
\hline Innovation & $\begin{array}{l}\text { Legislation should provide flexibility to enable local } \\
\text { governments to respond creatively to changing needs and } \\
\text { circumstances. }\end{array}$ \\
\hline Improvement & $\begin{array}{l}\text { Opportunities should be in place to enable councillors and } \\
\text { staff to undertake regular training to improve practice and } \\
\text { performance. }\end{array}$ \\
\hline Cultural respect & In addressing these principles local government systems \\
\hline
\end{tabular}


The above conceptualisation of effective local government was compiled by the University of Technology in Sydney (UTS), a project sponsored by the Commonwealth Secretariat and Commonwealth Local Government Forum (CLGF). ${ }^{47}$ Based on international practice and relevant literatures the principles identify a range of desirable characteristics for effective local government. The result is a comprehensive list of principles which has been designed to act as a benchmark in reviewing local government legislative frameworks. The UTS work sets out, in principle form, the characteristics or attributes that we might expect to see in any well-functioning local government system. In essence these are: a legislative framework which clearly spells out the expected role; ensures they have access to sufficient resources to implement that role; possesses the necessary level of autonomy to respond to local needs; and operates in a manner which is open, accountable and efficient.

A similar approach to defining principles is provided by Loffler (2003), who approaches community governance as an enhanced form of local government and has developed a comprehensive model which distinguishes both local government and community governance across a number of dimensions (see Table 11).

\footnotetext{
${ }^{47}$ Unpublished policy paper.
} 
Table 11 Characteristics of local government and community governance

\begin{tabular}{|c|c|}
\hline Local government needs to consider: & \\
\hline not only ... & ... but increasingly \\
\hline Organisational leadership & Leadership of networks \\
\hline Developing organisations & Developing communities \\
\hline $\begin{array}{l}\text { Ensuring policy coherence across } \\
\text { organisational departments and } \\
\text { services }\end{array}$ & $\begin{array}{l}\text { Ensuring policy coherence across } \\
\text { organisational and sectoral borders } \\
\text { and levels of government as well as } \\
\text { over time (sustainable development) }\end{array}$ \\
\hline $\begin{array}{l}\text { Creating a set of values and a sense } \\
\text { of direction which leaves room for } \\
\text { individual autonomy and creativity for } \\
\text { mid-level managers and employees }\end{array}$ & $\begin{array}{l}\text { Managing expectations of citizens, } \\
\text { companies and other stakeholders }\end{array}$ \\
\hline Policy and strategy & Balancing strategic interests \\
\hline Focus on the needs of customers & $\begin{array}{l}\text { Activating civil society (through } \\
\text { information, consultation and } \\
\text { participation) in local policies and } \\
\text { management }\end{array}$ \\
\hline $\begin{array}{l}\text { Separation of politics and } \\
\text { administration }\end{array}$ & $\begin{array}{l}\text { Public management as a process of } \\
\text { interaction between elected officials } \\
\text { politically appointed officials, ad hoc } \\
\text { advisers, career civil servants and } \\
\text { external stakeholders }\end{array}$ \\
\hline $\begin{array}{l}\text { Annual plans, concentrating on current } \\
\text { expenditure }\end{array}$ & $\begin{array}{l}\text { Long-term plans, incorporating } \\
\text { community plans, capital budget plans } \\
\text { and asset management }\end{array}$ \\
\hline People management & Management of the labour market \\
\hline Increasing labour productivity through & Improving staff contribution to all goals \\
\hline
\end{tabular}




\begin{tabular}{|c|c|}
\hline downsizing & of the organisation \\
\hline $\begin{array}{l}\text { Getting staff to focus on quality of } \\
\text { services }\end{array}$ & $\begin{array}{l}\text { Getting staff to focus on quality of life, } \\
\text { in terms of quality of service outcomes } \\
\text { for users and other stakeholders and } \\
\text { also quality of working life for fellow } \\
\text { staff }\end{array}$ \\
\hline $\begin{array}{l}\text { Motivation through more objective } \\
\text { evaluation systems and more flexible } \\
\text { pay systems }\end{array}$ & $\begin{array}{l}\text { Motivation by allowing staff to } \\
\text { contribute a wider range of their skills } \\
\text { and aptitudes to work of the } \\
\text { organisation }\end{array}$ \\
\hline $\begin{array}{l}\text { Recruiting and retaining qualified staff } \\
\text { through transparent hiring processes }\end{array}$ & $\begin{array}{l}\text { Recruiting, training and promoting staff } \\
\text { in ways which increase the diversity of } \\
\text { the public services in terms of gender, } \\
\text { ethnicity, age and disabilities }\end{array}$ \\
\hline $\begin{array}{l}\text { Making better use of staff resources } \\
\text { within the organisation }\end{array}$ & $\begin{array}{l}\text { Making better use of staff resources by } \\
\text { increasing mobility within the public } \\
\text { sector and also between other sectors } \\
\text { and other areas }\end{array}$ \\
\hline Resource management & $\begin{array}{l}\text { Resource and knowledge } \\
\text { management }\end{array}$ \\
\hline $\begin{array}{l}\text { Budget formulation as a top-down } \\
\text { exercise (with fixed ceilings on total } \\
\text { expenditures) }\end{array}$ & $\begin{array}{l}\text { Preparation of local budgets with } \\
\text { active participation of city councillors, } \\
\text { including community representatives. }\end{array}$ \\
\hline $\begin{array}{l}\text { Measurement of unit costs for } \\
\text { performance improvement and } \\
\text { performance monitoring }\end{array}$ & $\begin{array}{l}\text { Measurement of money and time costs } \\
\text { as experienced by organisation and } \\
\text { stakeholders }\end{array}$ \\
\hline Transparent financial reporting & Fiscal transparency to community with \\
\hline
\end{tabular}




\begin{tabular}{|c|c|}
\hline & $\begin{array}{l}\text { external stakeholders on value for } \\
\text { money }\end{array}$ \\
\hline Improving technical efficiency & $\begin{array}{l}\text { Improving social efficiency, including } \\
\text { equitable distribution of budgets }\end{array}$ \\
\hline $\begin{array}{l}\text { Making ICT available to all staff for } \\
\text { efficiency-enhancement purposes }\end{array}$ & $\begin{array}{l}\text { Generating and sustaining new } \\
\text { knowledge through knowledge } \\
\text { management, for both staff and } \\
\text { stakeholders }\end{array}$ \\
\hline Processes & Internal and external relationships \\
\hline $\begin{array}{l}\text { Internal business improvement } \\
\text { processes (business re-engineering) }\end{array}$ & $\begin{array}{l}\text { Managing processes beyond } \\
\text { organisational borders, including } \\
\text { intergovernmental relations and } \\
\text { constraints }\end{array}$ \\
\hline Competing for tendered tasks & $\begin{array}{l}\text { Managing multiple contracts and } \\
\text { supplier relationships and developing } \\
\text { co-production of services with users, } \\
\text { communities and other stakeholders }\end{array}$ \\
\hline $\begin{array}{l}\text { Measurement of objectives and } \\
\text { subjective results }\end{array}$ & $\begin{array}{l}\text { Measurement of multi-dimensional } \\
\text { performance }\end{array}$ \\
\hline $\begin{array}{l}\text { Reporting systems based on needs of } \\
\text { public managers and government } \\
\text { oversight bodies }\end{array}$ & $\begin{array}{l}\text { Publishing of performance information } \\
\text { based on the needs of stakeholders in } \\
\text { the community (social, ethical and } \\
\text { environmental reporting) }\end{array}$ \\
\hline $\begin{array}{l}\text { Benchmarking results, internal } \\
\text { processes or organisational } \\
\text { performance against other local } \\
\text { authorities }\end{array}$ & $\begin{array}{l}\text { Involving stakeholder groups in the } \\
\text { definition of performance standards } \\
\text { and measurement of performance }\end{array}$ \\
\hline Use of performance information for & Encouraging innovation and learning \\
\hline
\end{tabular}




\begin{tabular}{|c|c|}
\hline control purposes & $\begin{array}{l}\text { at multiple levels (individual, } \\
\text { organisational, networks) }\end{array}$ \\
\hline Functioning of the local authority & Developing good local governance \\
\hline $\begin{array}{l}\text { Serving the community by producing } \\
\text { policies, services and knowledge } \\
\text { (service provider) }\end{array}$ & $\begin{array}{l}\text { Enabling the community to plan and } \\
\text { manage its own affairs (community } \\
\text { developer) }\end{array}$ \\
\hline $\begin{array}{l}\text { Improving the internal efficiency of } \\
\text { local authorities }\end{array}$ & $\begin{array}{l}\text { Improving the external effectiveness of } \\
\text { local authorities }\end{array}$ \\
\hline $\begin{array}{l}\text { Increasing user satisfaction with local } \\
\text { services }\end{array}$ & $\begin{array}{l}\text { Building public trust in local } \\
\text { government through transparent } \\
\text { processes and accountability and } \\
\text { through democratic dialogue }\end{array}$ \\
\hline
\end{tabular}

(Source: Loffler 2003, p. 168)

Loffler's work begins by defining the dimensions of presumed 'good' local government and goes on to explain what needs to change for each dimension if a community governance approach is to be taken. The governance aspects have a strong external focus so that, for example, the 'processes' dimension becomes, in the governance mode, internal and external relationships. The common themes in Loffler's model are the way governance involves an extension of focus beyond the organisation and into the more fluid world of the community as a whole, such as civic organisations and businesses, as well as a strong focus on participation, integration and outcomes. It also emphasises the concept of empowerment and treats the local authority as an enabling organisation more than a provider. Compared with the UTS approach to local government principles Loffler presents a more diminished and organisationally focused version of local government, although she runs the risk of being seen to accentuate the differences in order to create a discrete model of community governance. 
In Loffler's interpretation the essential difference between local government and community governance is that the latter has a greater external orientation; it is concerned with outcomes and involves steering other agencies, although in practice the differences are probably a matter of degree. Most of the dimensions used by Loffler represent spectrums of local government practice with formality and hierarchy at one end and informality and responsiveness at the other. Her approach is consistent with the more abstract principles developed by Stewart and Clarke (1996) and the Bertelsmann Stiftung (2001). These are strong engagement with citizens and stakeholders (partnerships); facilitating citizens to set community goals; network management and policy coordination; working beyond organisational mandates; strengthening civil society; and a focus on the quality of life. Similarly, the analysis of community governance theories at the end of Chapter 2 identified a number of common themes which replicate the principle frameworks discussed above. They are a focus on citizens and communities; multiple roles played by councils; interagency collaboration; strategic or long-term thinking; the creation of community visions; and inclusiveness. These have been incorporated into the assessment model described below.

\section{Developing an assessment model}

Principles, by their nature, are inevitably difficult to translate into guidance for action. Can we assume, for example, that all principles are of equal weight and importance or should some be given preference? Even when we know the relative importance of a principle how do we determine the appropriate weighting that should be applied? For example, having sufficient autonomy to respond to community needs may be an important principle of community governance, but how autonomous do councils need to be? Having sufficient income sources to respond to such needs may also be an important principle but are some methods of funding better than others? The next section attempts to address these issues by proposing an assessment model that consists of a framework of principles, dimensions and measures. 
Developing an assessment model involves identifying, at a reasonably high level of abstraction, principles which would need to be exhibited in any local government framework if it was to exercise community governance. Drawing on the theoretical work on community governance and the more applied work on principles discussed in this chapter, six principles are proposed for the assessment model. These are:

1. Authority: councils exercising community governance have sufficient authority to make decisions on matters of local public interest.

2. Autonomy: councils exercising community governance can respond to citizens' concerns without undue restrictions imposed by higher authorities.

3. Outcome orientation: councils exercising community governance are concerned with broad intersectoral outcomes of concern to their citizens.

4. Community focus: councils exercising community governance involve citizens and stakeholders when determining priorities and the community's long-term direction.

5. Partnership: councils exercising community governance undertake policy and operational co-ordination with other organisations including other levels of government.

6. Inclusiveness: councils exercising community governance implement mechanisms to allow citizens to participate in decision-making.

The purpose of the model is to assess the capacity of the local government system in New Zealand to take on a community governance approach and identify areas that would need to change or be enhanced. The first two principles concern the underlying legislative and regulatory framework of the local government system and involve the concepts of authority and autonomy. In order for community governance to occur the local authority must be regarded as an authorising agent, that is, it should be seen as having both legitimacy and status in the eyes of local citizens. Councils must also have a sufficient level of autonomy to enable them to negotiate with disparate local interests and have a capacity to act on agreements subsequently entered into. This requires an appropriate level of powers and competencies to implement 
policies and influence events to the degree that local authorities themselves determine.

The outcome orientation principle is concerned with the degree to which local authorities are focused on the achievement of community-wide outcomes as opposed to an exclusive focus on the delivery of specific organisational outputs, and the manner in which they exercise their leadership mandate. The 'community-focused' principle highlights the manner in which councils involve their stakeholders and citizens when setting direction and agreeing priorities - it is primarily concerned with leadership. The collaboration principle examines the degree to which, recognising the multi-faceted nature of many of the issues affecting communities, councils are engaged in resource sharing and/or other collaborative relationships, particularly with higher level governments. Finally the inclusiveness principle captures the fundamental importance of strong democracy and the role citizens can and should play in setting the direction of the local authority and determining priorities.

In order to 'operationalise' the assessment model, dimensions and specific measures are required. Loffler groups her principles into seven dimensions ranging from leadership and strategy to performance and oversight. The dimensions are a combination of process attributes, institutional factors and operational style. For the assessment model 10 dimensions have been selected. This has been done by disaggregating the system of local government into its basic parts and selecting those that are relevant to each principle. For each dimension one or more measures have been identified in order to determine the ability of the dimension to adopt a community governance approach. Assessments simply identify the dimension as 'adequate' for achieving community governance or 'needing improvement'. The dimensions and measures are:

- $\quad$ size and structure: size is selected as a proxy for capacity; that is, do New Zealand councils have the necessary level of resources to actively contribute to community governance? Structure concerns the ability of systems of local government to undertake activities which have different 
levels of benefit and thus beneficiaries. The measures for this dimension are local authority average populations (a proxy for capacity) and the prevalence of multi-level governance arrangements (to indicate ability of the local government sector to deliver services that benefit diverse areas)

- empowerment: this dimension is concerned with the manner in which local authorities are empowered. Are local governments' powers tightly defined, through, for example, the principle of ultra vires, or do they have some form of general powers? The choice of powers determines how well the system can respond to citizen concerns and expectations. The measure is the presence or otherwise of general empowerment

- finance: this dimension is concerned with councils' financial autonomy, that is, the degree to which local authorities are able to make local expenditure decisions without oversight from higher levels of authority. Local government systems in which funding is determined by higher level governments tend to have less discretion in the way resources are prioritised and local spending decisions made. The measure is the proportion of 'own tax' revenue raised by the local government system

- central government supervision: questions about authority and autonomy are answered not only by examining the constitutional status of local government but also by looking at the degree to which national governments 'steer' the activities of lower level governments and the nature of the steering mechanisms employed. The measure for this dimension is the place where New Zealand sits on the spectrum of mandatory and discretionary steering mechanisms

- functions: the choice of functions as a dimension is to highlight the degree to which councils are able to make decisions that have a direct effect on the well-being of their respective communities. Measures are the proportion of local government expenditure that makes up national gross domestic product (GDP), overall public expenditure and the range of functions undertaken. The more significant these are the more a system is seen to be contributing to well-being 
- strategy: virtually all local authority systems either require or encourage councils to undertake some form of strategic planning. This dimension is concerned with whether or not strategy is organisationally focused or externally and outcome focused. The measure concerns whether or not councils have a statutory mandate to undertake outcome-focused community strategic planning and the New Zealand approach is compared with the approaches taken in England and the Republic of Ireland, both of which reflect a strong community governance orientation in their design

- leadership: this indicator is concerned with the nature of local government leadership and whether or not it is optimally situated to provide 'community leadership' as described in the community governance literature. The measure is the existence or otherwise of directly elected mayors

- collaboration: this dimension examines the degree to which the statutory framework governing local government encourages or requires councils to 'join up', that is, participate in joint service delivery or planning initiatives. The measure examines the degree to which such directives or incentives are required

- decision-making: this dimension examines the range of opportunities citizens have to influence the decision-making processes undertaken by their elected representatives. The measure for this indicator examines legislative or statutory requirements to consult or involve citizens in decision-making

- local democracy: this indicator is concerned with the 'thickness' of local democracy and the strength of representation. The two measures are representation ratios and the role of sub-municipal bodies. High representation ratios are regarded as diminishing voice and consequently citizens' influence on council decision-making. In contrast, the presence of sub-municipal bodies is regarded as enhancing opportunities for citizens to exercise 'voice'. 


\section{The local governance assessment model}

The assessment model is described in full in Figure 5. The assessment itself is undertaken in Chapter 7.

Figure 5 Local governance assessment model

\begin{tabular}{|c|c|c|}
\hline Principle & Dimension & Measure \\
\hline \multicolumn{3}{|l|}{ Authority } \\
\hline & Size and structure & \\
\hline & & $\begin{array}{l}\text { Average population per } \\
\text { council }\end{array}$ \\
\hline & & Multi-level capacity \\
\hline & Finance & \\
\hline & & $\begin{array}{l}\text { Proportion of 'own tax' } \\
\text { revenue }\end{array}$ \\
\hline \multicolumn{3}{|l|}{ Autonomy } \\
\hline & Empowerment & \\
\hline & & $\begin{array}{l}\text { Existence of general } \\
\text { competence type powers }\end{array}$ \\
\hline & $\begin{array}{l}\text { Central government } \\
\text { supervision }\end{array}$ & \\
\hline & & $\begin{array}{l}\text { Use of non-mandatory } \\
\text { steering instruments by } \\
\text { central government }\end{array}$ \\
\hline \multicolumn{3}{|l|}{ Outcome orientation } \\
\hline & Functions & \\
\hline & & $\begin{array}{l}\text { Expenditure as a } \\
\text { proportion of GDP and } \\
\text { public expenditure }\end{array}$ \\
\hline & & $\begin{array}{l}\text { Range of mandatory } \\
\text { functions }\end{array}$ \\
\hline \multicolumn{3}{|l|}{ Community focus } \\
\hline & Strategy & \\
\hline
\end{tabular}




\begin{tabular}{|l|l|l|}
\hline & & $\begin{array}{l}\text { Outcome-based strategic } \\
\text { planning mandatory }\end{array}$ \\
\hline & Leadership & $\begin{array}{l}\text { Role of mayors and form } \\
\text { of selection }\end{array}$ \\
\hline Partnership & & Range of mechanisms to \\
& & Collaboration joined-up activity \\
\hline & & $\begin{array}{l}\text { Opportunities for citizen } \\
\text { involvement }\end{array}$ \\
\hline Inclusiveness & Decision-making & Representation ratios \\
\hline & & $\begin{array}{l}\text { Existence of sub- } \\
\text { municipal bodies }\end{array}$ \\
\hline & Local democracy & \\
\hline & &
\end{tabular}

The assessments will be undertaken using a number of approaches. Where appropriate data is available comparisons will be made to other local government systems to determine where New Zealand sits on relevant spectrums. Where comparative data is not available assessments will draw on original source documents already in the public domain, including archived material and relevant academic papers, such as annual reports, Long Term Council Community Plans, refereed journals and official government publications.

\section{Conclusion}

The assessment model has been designed to assess the capacity of the local government system in New Zealand to adopt a community governance approach. The model is based on common themes identified by community governance theorists and also draws on the work of a range of commentators who have sought to develop their own community governance principles. Each 
of the 10 dimensions will be assessed as being either adequate or needing improvement and are discussed in the final chapter. 


\section{Chapter 4 The role of local government}

This chapter discusses theories and frameworks of local government, including recent international trends regarding local government reform and community governance. It also examines a range of meta-trends which are used to explain the recent growth of interest in governance and local government.

The New Zealand Government's decision to establish a commission to examine the way in which the metropolitan area of Auckland should be governed signalled a growing realisation that the way decisions are made in cities and districts matters, and may have national consequences, particularly in large metropolitan areas. This understanding has not always been the case, at least in New Zealand, as the following editorial lament suggests:

Once again the movement for local government reform has foundered on the rocks of political expediency ... It is simply a reversion to the laissez faire of yesteryear. ... History records 31 years of non-achievement in local body reform (Timaru Herald, 21 October 1977, quoted in Boswell 1981).

The history of local government reform in New Zealand has been one of benign neglect, in which ministerial efforts to reform the sector were rebuffed by successive governments until the fourth Labour Government rose to the challenge. Since that time local government reform has continued with remarkable frequency, with the Government's response to the Royal Commission indicating that it continues to be a matter of official concern, particularly the governance of large cities. This ongoing interest, which is replicated in most other parts of the developed world (see Dollery and Robotti 2008), has resulted in a growth in the academic interest in, and theories about, the role and nature of local government. These theories are drawn broadly from the disciplines of economics and political science. 


\section{Economic theories of local government}

Both economics and political science have advanced strong arguments for robust systems of local government, each discipline highlighting different roles played by councils in economic and political life. Economists regard governments as playing four primary economic roles: allocation, distribution, regulation and stabilisation, with local government being primarily concerned with the allocation functions and to a lesser degree regulatory functions (Bailey 1999). Regulation is primarily undertaken at a national level, but local government may act as a regulatory agent; it may also be better placed to determine appropriate regulation of matters of local importance, such as liquor bylaws. In addition, councils are well placed to address instances of local market failure, for example, in local sewerage services, where the cost of developing infrastructure and the inability to charge consumers for their use of such infrastructure limit non-public providers (ibid).

The economic case for local government also hinges on the value of decentralising or devolving services to lower-level governments to meet the diverse preferences of consumers. This is seen to enhance efficiency as councils can operate more like markets than hierarchies, resulting in levels of service that are more likely to reflect the preferences of local citizens. Bailey (1999) distinguishes three types of decentralisation:

- economic decentralisation - which is concerned with the location of economic decisions (for example, with the consumer)

- political decentralisation - which provides sub-national governments with the power to levy taxes and charges so as to deliver self-determined outputs

- administrative decentralisation - which creates regional offices of central departments, normally lacking any policy discretion.

The three forms of decentralisation are not mutually exclusive and may operate alongside each other, varying according to policy arena. In fact any comparative study of local government would note that they occur in differing combinations 
in almost every country. While decentralisation might make economic sense under certain conditions, the policy challenge is to determine what those conditions are and which services should be decentralised. A number of theories attempt to answer this question, such as fiscal federalism, which is discussed below.

\section{Fiscal federalism}

Fiscal federalists argue that local governments exist to provide "goods and services whose consumption is limited to their own jurisdictions" (Oates 1999, p.1121) and that doing so will ensure greater economic welfare than a more uniform provision of services from the centre. Fiscal federalists argue that by decentralising services local governments can match citizens' preferences better than national governments, as people can shift between jurisdictions until they find one that provides the range of services they desire. What has come to be known as 'Oates' decentralisation theorem' states that local governments should "be created such that preferences vary little within localities but vary strongly between them" (Bailey 1999 p. 21).

Fiscal federalism captures many of the popularly advanced arguments for devolution and decentralisation, including the argument that devolution to local government encourages new ideas and initiatives which could not be safely tried at a national level. In other words, the smaller scale of local governments limits the consequences of government failure!

One of the economic arguments underpinning fiscal federalism is the suggestion that devolution and decentralisation make economic sense because they give voters more control over decision-makers. This idea was also advanced by the work of Tiebout in 1956 (see Bailey 1999), who suggested that local governments could act in a similar way to markets. This occurs when dissatisfied residents express disapproval by 'exiting' their council and shifting to a different local government administration, one which provides a range of goods and services that more closely match their preferences. In this way efficiency would be enhanced and performance improved as local governments seek to satisfy the majority of their citizens. 
While the theory is attractive the Tiebout model makes assumptions that limit its real-world application. First, it assumes that citizens have full information about the differences in revenue and expenditure patterns and the goods and services provided by different local authorities and are able to make rational comparisons (taking into account issues of cost and quality). Second, it assumes that exit is relatively free of cost, which requires local governments to be small and numerous. A third assumption is that each council can influence the full range of local services, which often is not the case. In practice these conditions are seldom met. For example, it is difficult for citizens to get information on councils' performance and so make appropriate assessments about cost and quality; exit is unlikely to be costless, and the ability of councils to influence the full range of local services is often constrained by higher authorities that often set national service levels as well as the use of regional service arrangements, which effectively diminishes local differences. ${ }^{48}$

\section{Bailey's contribution}

In contrast to the pragmatism of the fiscal federalists, Bailey (1999) takes a more principle-based approach, suggesting that the question of determining which level of government does what can only be solved by considering the "profound multidirectional interdependencies between structure, functions and finance" (Bailey 1999, p. 116). His concern is with achieving allocative efficiency, which, he suggests, involves matching form, function and finance. The criteria he advances for achieving this matching include the following:

- Local government should provide the majority of public sector services because their benefits are localised.

- Local government should only provide services where the risk of local market failure is high and government failure is low.

- The jurisdictions of local governments should, as far as practicable, be coterminous with the areas benefiting from the provision of their services.

\footnotetext{
${ }^{48}$ Marsh and Kay (2004) suggest that the empirical evidence for the Tiebout effect is less than convincing, especially outside the fragmented local governance environment of the United States.
} 
- Councils should be as small as possible, while still achieving economies of scale.

- Scope for exit should be facilitated by increasing inter-municipal competition for residents, and decentralisation of services within council areas (Bailey 1999).

In Bailey's view the optimal size of local government units reflects a trade-off between the benefits of decentralisation and the possible loss of economies of scale. A critical aspect of his approach is his assertion that the "geographic size of municipalities needs to match the areas benefiting from service provision in order that those who benefit from a service bear the local tax costs financing it" (ibid, p. 228). The practical challenge, however, is to match the geographical spread of benefits with the liability to pay taxes. Bailey's answer is to make jurisdictions as large as practicable while maintaining democratic legitimacy and opportunities for citizens to participate in decision-making. Larger jurisdictions prevent tax exporting and spillovers and minimise fiscal disparities between the taxable resources of communities.

Finding this balance is far from simple, however. While the fiscal federalists undervalue the strategic fit between form, function and financing and fail to resolve the accountability problem created by fiscal transfers, Bailey's solution poses a different problem. Achieving the appropriate fit requires larger jurisdictions but larger councils tend to be less democratic with lower voter turnout and fewer mechanisms by which citizens can influence decision-making and so hold officials to account; that is, they tend to be more bureaucratic and elected members less accountable (Drage 2008). His approach continues to beg the question of how to design institutions to achieve the alignment between areas of benefit and political jurisdiction without losing the responsiveness that comes with smaller local authorities. The answer is inevitably going to be influenced by context and the range of services local governments are expected to deliver. Bailey is writing for a predominantly British context and, given the social policy responsibilities undertaken by British councils, larger jurisdictions have a logic that is not present in systems with a different mix of service responsibilities. Given New Zealand local government's minimalist functional 
responsibilities, area of benefit is primarily defined by the extent of the infrastructure networks owned and operated by councils, such as the number of communities attached to a council's water or wastewater networks - other factors are less likely to apply.

\section{Political theories of local government}

Political theories of local government tend to emphasise its role in the development of citizenship and the distribution of power, rather than the efficient delivery of public goods. De Tocqueville expresses this eloquently when he argues that local government is necessary to give citizens the experience of government and act as schools of citizenship. His study of American democracy in the early 19th century found evidence that participation in local self-governing associations and local governments enabled citizens to come together to discuss their common needs and increase their awareness of the needs of others (see Siedentop 1994). This observation also underpins much of the more recent theory of civic republicanism, which sees the practice of self-government as building character and enhancing democracy (see Sandel 1996).

A related view regards local government as a check and balance on the power of the executive. From this perspective popular decentralised self-government helps guarantee the freedom of local communities, maintaining the separation of powers in which the interdependence of society dictates that all members should be active in promoting the public interest to avoid the possibility that government is left to a minority or distant elite (Norton 1994). Ensuring that public authority is distributed over a number of levels of government also reduces the ability of any one level of government to concentrate power in its hands alone. "Decentralisation of power and local solidarity are principal means to counteract the threats to freedom that any gap between rulers and ruled implies" (ibid, p. 31). Further checks and balances are provided simply by the existence of an empowered and legitimate local government system. John Roberts argued more than 40 years ago that: 
the growing power of government, as evidenced by its ever increasing intervention in the economic and social affairs of the people, constitutes another reason for the existence of an efficient system of local government. While central and local government must share, as collaborative partners, the total task of governing the nation, an effective local government structure is an important counterweight to the growth of central government power. Local government is not solely a matter of the management of local services; it provides the democratic machinery for the expression of local opinion on all matters of public policy (Roberts quoted in Boswell 1981, p.30).

Political theory also recognises that local government provides a learning ground for budding central government politicians. It has lower barriers to entry, which allows participation by a wider and more representative group of individuals, while also giving new politicians a chance to develop their skills and experiment with innovative policy ideas (see Lyons 2007). Also highlighting the value of distributed government, Buchanan (1995/96) promotes the concept of competitive federalism and argues that federal systems which distribute power between levels of government offer better protection of individual liberty than unitary systems of government, particularly if the political units are small. $\mathrm{He}$ notes, in particular, that a vote is worth proportionately more in communities with small numbers of voters, and in such communities it is easier for citizens to organise in order to replace political incumbents. While Buchanan's notion of competitive federalism is indebted to Tiebout's work on exit, he acknowledges the concept's real-world limitations (that is, ideal conditions are seldom realised) by arguing that 'virtual exit' may be just as effective as real exit. Virtual exit represents the possibility or threat of exit, and in order to change political behaviour the threat may be as important as exit itself. Just the existence of neighbouring councils that are perceived as operating more efficiently or effectively creates moral pressure on elected members to improve their performance. 


\section{Localism}

Localism is a normative belief in the value of local decision-making. It is generally justified on the basis of three values: democratic participation in public affairs; the efficient allocation of public goods and services; and community strengthening (see Filkin et al 2000). The participation argument, in particular, is based on the assumption that smaller localities are more effective at providing opportunities for meaningful political participation than larger authorities, reflecting citizens' access to decision-makers. Participation is also regarded as a valuable social good in its own right because it enhances moral autonomy and builds a sense of local identity (Sandel 1996, Putnam 1995, Sen 1999). Ultimately it is seen to promote civic virtue, and understanding, and strengthens 'bridging' social capital, that is, the increased social trust that comes from engagement between diverse communities (Putnam 1995, Muhlberger 2000).

Proximity to local governments can also help citizens ensure that decisionmakers provide the range of local public goods and services that meet their particular needs and preferences. This argument emphasises the heterogeneity of the national community and the difficulties faced by national providers (central government) in tailoring services to the circumstances and preferences of diverse communities. Locating decision-making as closely as possible to the communities affected by decisions is also seen as a way of strengthening community in its own right. Putnam's (1995) work in Northern Italy notes the relationship between the strength of regional government and the degree to which citizens participate in clubs and societies and theorises that high social participation is related to responsive and effective governance at the regional level. Local government is one of the arenas for civic engagement that contributes to social capital. It also encourages citizens to believe they have a stake in their own communities, in contrast to feelings of disempowerment that tend to be associated with larger and more remote governments, reflecting, perhaps, the fact that trust in local government tends to be higher than trust in national governments. ${ }^{49}$

\footnotetext{
${ }^{49}$ See Community Perceptions of the Three Spheres of Government, Local Government and Shires Association of New South Wales, GPO Box 7003, Sydney.
} 
Despite the value of participation and proximity, when it comes to designing the institutions of government localism has a number of shortcomings. Cashin (1999), for example, argues that voters behave more self-interestedly when decision-making authority is brought closer to them, citing a common practice in the United States for well-off suburbs to incorporate as separate authorities in order to avoid the cost of supporting the urban poor. She uses the phrase 'tyranny of the favoured quarter' to describe the increasing fragmentation of local governance in many states that has resulted in metropolitan regions stratified by race and income. Localism, in this context, represents extreme parochialism and a political NIMBYism. ${ }^{50}$ Localist forms of governance are also poorly placed to deal with externalities and spillovers, such as where one community benefits from taxes paid in a neighbouring community, and require additional co-ordinating mechanisms since some services must be provided regionally (see Bailey 1999).

\section{Subsidiarity}

A complementary but more sophisticated discourse, subsidiarity, captures many of the promises of localism while recognising its limits. From its first articulation in 1931 by Pope Pius XI in the encyclical Quadragesimo Anno (Novak 1996), subsidiarity has provided a normative justification for strengthening the role of citizens in public affairs. Locally, one of the clearest definitions of subsidiarity was made by the Royal Commission into Social Policy established by the fourth Labour Government in New Zealand more than two decades ago. The commission defined subsidiarity as the principle that "no organisation should be bigger than necessary, and nothing should be done by a larger and higher unit that can be done by a lower and smaller unit" (Royal Commission on Social Policy 1988, p. 806). However, the concept has had a limited impact in New Zealand, as the commission's report has largely been ignored by both the fourth Labour Government and its successors and the concept of subsidiarity is seldom seen in public sector discourse. The concept has, however, had a much

50 'Not in my backyard' syndrome. 
more positive reception in parts of Europe and the European Union itself, where it has been incorporated in the European Charter of Local Self Government. ${ }^{51}$

As a concept to guide policy-making, subsidiarity is helpful as it avoids some of the difficulties of localism by recognising the degree to which the technical characteristics of some public goods and services will result in diminished public welfare should they be provided solely by localities. For example, services that require a high degree of technical knowledge but occur infrequently will inevitably need to be undertaken by high level governments, where costs can be spread over a bigger community and demands for expertise are likely to be greater. While subsidiarity theorists debate the nature of the technical characteristics that might justify provision by higher levels of government, in broad terms they are seen to involve economies of scale and redistributive factors.

\section{The drivers of local government reform}

One of the features of the last few decades has been the efforts by many developed countries to reform their local government systems, with economic theory, in particular, a major driver. In recent years countries examining the form, functions or financial arrangements of their local government systems have included Denmark, Ireland, Scotland, England, New Zealand, all the states of Australia, South Africa, Fiji and several provinces of Canada. In many of these countries change has almost become the norm as governments struggle to find the policy settings that balance macro-economic concerns with efficiency, and national policy objectives with citizens' expectations to influence decisions which affect their communities. This relatively universal focus on local government, accompanied by ongoing public sector reform, is largely explained by a series of exogenous factors that have changed the context in which governments operate. Three factors, in particular, are relevant to the subject of this thesis: globalisation, increasing social diversity and a demand for greater autonomy or civic participation (Albrechts 1991, Albrow 2001).

\footnotetext{
${ }^{51}$ See http://conventions.coe.int/Treaty/en/Treaties/html/122.htm.
} 
The impact of globalisation has been a specific factor behind the British Government's thinking about local government reform. In a recent paper it commented that "the increasing interdependence of the world economy means that every nation, region and city of the UK faces more intense global competition" (ODPM 2006, p. 55). In a world in which capital has become increasingly 'footloose', councils, if they are focused on enhancing the wellbeing of their citizens, will need to be aware of the implications of globalisation and respond to them as appropriate to their level of authority. Support for the proposition that increasing globalisation and social change creates roles for localities and sub-national governments comes from commentators across the political spectrum (Vargas Llosa 2001, Bell 1973, Habermas 1992, Etzioni 1996). These writers have in common a view that the locality, or at least the sub-nation, is now a meaningful site for political debate and allows engagement by a much broader range of policy actors than previously, that politics is now much less an activity of the elite. Arguing for a 'New Westphalian' paradigm to strengthen global and sub-national forms of governance (the Treaty or treaties of Westphalia ended the Thirty Years War in 1648 and established the system of nation states as we know it today), Valaskakis (2001) pictures a world in which, because of new challenges, "national governments are in the process of becoming bit players of the new era" (ibid, p. 56) and calls for new governing institutions.

These challenges might be seen as reflecting a shift of power from political to economic decision-makers, perhaps indicated by the rise of multi-national corporations and the transfer of decision-making authority to international governing organisations, such as the World Trade Organization and International Labour Organization. Sassen (2006) describes this process as one of "denationalisation", in which global firms become informal political agents and historical national goals are gradually displaced by global aims (ibid, p. 5). It is also associated, in her view, with a hollowing out of legislatures and parliaments and a strengthening of executive power, creating the space for local governments to act in order to fill the resulting vacuum. Other writers also make a similar link between globalisation and local governance (see Andrew and Goldsmith 1998, Harmsworth 2001). Tarschys (2001), for example, argues that 
the modern state is effectively squeezed between two competing forces, "a more assertive local and regional level of government on the one hand and the dynamics of international and supra-national regulation on the other" (ibid, $p$. 33). Indeed large urban regimes, like New York and Tokyo, are regarded as forming the basis for new transnational networks which have the potential to effectively take on the traditional roles of the state (Sassen 2006). The phenomenon in which globalisation is changing the role of the state and making room for more localised forms of governance is reinforced in the theory of 'glocalisation', which takes the view that local identities increase in importance as the national sphere of identity erodes.

The glocalism concept suggests that local identities acquire more importance as global decision-making increases in scale, as it is through local identities that citizens both understand and relate to a global environment marked by uncertainty. Economic integration therefore enhances rather than diminishes the local community. As globalisation intensifies, smaller units of political affiliation may be relied on to a greater degree to meet citizens' expectations and channel citizen identities (Paasi, quoted in Harmsworth 2001, p. 7).

The theory of glocalisation provides an alternative take on the effects of globalisation by suggesting that instead of increasing homogeneity, globalisation has created the opportunity for greater local difference. Advocates for the theory argue that some local governments and communities have in fact already seized these opportunities. Yet it is not only external factors, like globalisation, that are undermining the efficacy of the state and its traditional policy levers. Social change is having a similar effect. Increasing diversity makes it more difficult for hierarchical and command and control decisionmaking models to operate. The growth of multiple identities and multi-cultural communities with different expectations has challenged the welfare state consensus and its one-size-fits-all approach, creating a situation where the concept of a "dominant state-centred welfare has corroded and lost its hegemony" (Evers quoted in Williamson 1999, p. 30). 
Diversity is reflected not only in the social and demographic makeup of contemporary societies, but also in their economic foundations and the shift from 'Fordism' to 'post-Fordism', which has implications for both the private and public sectors (Stoker 2000, Giddens 2000). The term Fordism, referring to the assembly-line manufacturing processes introduced by Henry Ford, has been employed more broadly to describe any process designed to produce large quantities of single components at the lowest price. It has come to be used also as a generic label for social and commercial institutions that deliver standard products on the assumption that customers' preferences are uniform. Such approaches to production, however, struggle to meet the different needs and preferences of plural and diverse communities. Parsons (1997) argues that control through hierarchies (Fordist organisations tend to be hierarchical) has given way to less bureaucratic, flatter, more fragmented post-modern or postFordist structures. Post-Fordist advocates, such as Stoker (2000), argue that changing modes of production and expectations among consumers have implications for local public services, which will need to reflect the differences of individual communities and respond to their needs and wants as the market responds to customers, particularly with the growth of multi-cultural communities. While the Fordist/post-Fordist discussion arguably simplifies complex social and economic phenomena, it serves to highlight the degree of change taking place in our social, economic and political systems. Such changes have implications for the relative roles of local and central government.

Adding to the pressures created by the challenges of globalisation and diversity, governments are also being confronted by a citizenry at once less trusting of governments, ${ }^{52}$ less inclined to use traditional forms of democratic participation, such as voting, and more demanding that its views be considered. Whereas globalisation effectively creates external constraints on the state's freedom of action, the demands of civil society to participate in public decision-making create an equivalent internal constraint, such as the growing interest in proportional voting systems as a way of providing opportunities for a broader

\footnotetext{
${ }^{52}$ Surveys taken in the United States since 1958 show that the proportion of citizens who agree that "you can trust the government in Washington to do what is right has fallen from 63 per cent to 27 per cent (Ladd 1998). Preliminary data for 2008 shows that confidence in the executive branch and Congress had fallen to 11 per cent (The Economist, 28 March 2009, p. 36).
} 
range of political actors and to limit executive power. Similar pressures are occurring in local government (Williamson 1999).

As citizens articulate their needs and preferences more clearly, increasingly outside traditional party mechanisms, governments have been forced to find ways of being more responsive. Some commentators suggest that a new form electoral politics has been formed, one of "continual mediation ... in order to preserve balance and maintain social harmony" (Lakoff 1996, p. 34). Lakoff argues that to be effective governments must establish institutions and processes that allow the diversity of voices in communities to be heard. Perhaps the greatest indication of this, in practice, is the recent tendency of many governments to devolve responsibilities to local governments and to require such governments to adopt innovative practices, such as citizen participation techniques. Consistent with these trends, citizenship is proposed as a critical concept in the reconceptualisation of local government, particularly for constructing localities and providing a rationale for loyalty to local communities (Andrew and Goldsmith 1998). Paradoxically, shared citizenship, which involves equal rights to services and a vision of inclusiveness, allows local differences to be resolved (ibid). Citizenship "speaks to the link between individual and community levels of identity, and local citizenship conveys the potential for local government structures to represent and reinforce the interrelationship between individual and collective identities" (ibid, p. 110). In the United States, for example, the pressure for greater civic participation has been reflected in neighbourhoods, towns and local communities by the growth of a movement of citizens acting together to solve community problems:

It is a non-partisan movement that crosses traditional jurisdictions and operates on a shoe-string. It is a movement that begins with civic dialogue and leads to public action (National Commission on Civic Renewal, quoted in Livable Communities 2000, p. 15).

Community-based demands for a greater say in how their communities are run are replicated throughout most of the developed world, if not more widely, and have driven recent changes to local government practice. In fact there has been 
a high level of convergence, reflecting the dominance of particular reform ideologies and the transfer of ideas between countries. ${ }^{53}$ For example, the New Zealand approach to long-term financial planning has been replicated in South Australia, Queensland and New South Wales.

\section{Modernisation}

One theme that has shaped much of the thinking about reform, at least up to the end of the 1990s, is the idea of modernisation, a contested idea which Christopher Hood described as one of the most powerful themes in contemporary management (Hood 1998 quoted in Dollery and Wallis 2001b). In its widest sense 'modernisation' is a way of speaking about a distinct range of changes to the institutions and practice of governments which have occurred to various degrees over the last two decades of the 20th century - reforms that challenged the prevailing Weberian-based model of public administration and its heavy reliance on rules and hierarchy.

The modernist challenge to the traditional form of public administration is well documented (see Boston 1991a and 1991b) but there is less consensus about the reasons or need for change. Boston suggests that fiscal imperatives were a decisive influence leading to change along with a general political shift to the right and a corresponding interest in privatisation and commercialisation (Boston 1991a). Others saw it as a reaction to growing bureaucratisation, which was seen to slow development and undermine the capacity for innovation, leading to "less national government, less central government, but greater governance over local processes" (D'Alema quoted in Giddens 2000, p. 5). The modernist agenda, however, has not met with universal enthusiasm. Kelsey (1994), for example, questions both the results of, and necessity for, reform, which she describes as implementing a dogmatic liberal agenda resulting from a crisis of legitimacy in the western democracies.

The modernisation project set out to organise bureaucracies so that departments have clear and consistent objectives, a high standard of

\footnotetext{
${ }^{53}$ For example, there is regular contact between officials and academics in New Zealand and many Australian states, including a joint local government Ministerial Committee.
} 
accountability, transparency regarding trade-offs, less likelihood of provider capture, contestable provision of advice, and the removal of trading activities from direct political control. As Boston describes the phenomenon, changes to the machinery of government sought to achieve "consistency, accountability, transparency, contestability, complementarity, co-ordination, economy, efficiency, the minimisation of capture and improved bureaucratic representation for dis-advantaged groups" (Boston 1991b, p. 239). In short, the objective was a public sector that was more likely to be responsive, arranged in a way that would reflect a greater plurality of voices, and focused on outcomes.

Similar purposes guided the reform of local government, particularly in New Zealand. The reform agenda reflected a strong commitment to increasing transparency, accountability and efficiency and resulted in large scale consolidation as the multiplicity of small single and multi-purpose local bodies was merged into a much smaller number (see Chapter 1). Corporate sector practices, such as the separation of trading activities and removal of elected members from the operation of councils, followed. In addition, possibly reflecting local government's uncertain constitutional place, the Government has also introduced policies that create greater accountability to citizens through compulsory consultation and the requirement to prepare annual plans, reports and long-term financial strategies. Internationally, reform followed multiple paths, reflecting both local political initiatives and competition between states:

the trends towards administrative restructuring currently under way, the breakthrough innovations and the numerous negative developments, point to two central key problems which represent the two central challenges for local government in the run-up to the 21st century. These are how to make the transformation from:

- sectoral optimisation strategy to strategic management of overall administration (and) 
- internal modernisation to redefinition of boundary between local administration and its political, economic and social environment (Naschold 1997, p. 25).

Drawing on a number of international studies Naschold argues that reform has seldom been consistent, sustainable or even in the same general direction and suggests that local government modernisation consists of three meta-trends. These are internal rationalisation, democratisation and market orientation.

- Internal rationalisation. This largely captures what Boston (1991a) refers to as 'machinery of government' reforms. It includes a separation of outcomes and outputs, accrual accounting and more flexible work and personnel practices, along the lines of New Public Management.

- Democratisation. This involves more community participation in decisionmaking and the devolution of decision-making to lower orders of government and organisations in civil society.

- Market orientation. This consists of increasing corporatisation, privatisation and use of market-type instruments, such as external contracting and market testing.

The rate at which the reform trends have been taken up and 'bedded in' varies. In New Zealand more emphasis appears to have been placed on internal modernisation and the use of market-type interventions than on devolution, democratisation and the empowerment of civil society. While noting that modernisation has resulted in both successful innovation and institutional failure, Naschold argues that a greater challenge for local governments was to manage the transition from internal modernisation to the development of strategic management. Modernisation, as carried out in the eighties and nineties, tended to be organisationally focused with a concern to improve efficiency and accountability. Still to be achieved was the "redefinition of the interfaces between local administration and politics, society and the economy" (ibid, p. 5). 
The process of change is 'lumpy', with initiatives in up to half the councils in Naschold's sample either stagnating or regressing, leading him to suggest that a process of 'demodernisation' was also occurring in some jurisdictions.

"Modernisation is not merely a linear institutional evolution involving cumulative differentiation, specialisation and innovation at ever higher levels, but also exhibits strategic dis-continuities, reverses and signs of dis-integration" (ibid, p. 12). Being a non-linear process, modernisation represents an uneven progression of reform elements with different jurisdictions emphasising different elements. For example, in their study of local government reform in Australia, Marshall and Sproats (2000) describe the way in which some states, such as New South Wales (NSW), gave priority to enhancing democracy, while other states, notably Victoria, emphasised efficiency. The result was a very different approach to the issue of consolidation, where NSW left the decision up to communities themselves, in contrast to Victoria's top-down process, which saw the number of councils cut to less than a third by state decree.

Despite the tendency to treat modernisation as a largely technical exercise, many of the elements considered to be part of the modernisation agenda were, and continue to be, contentious. While different approaches were taken to the issue of consolidation, the same is also true of devolution, with some countries adopting it with enthusiasm and others giving it less than 'lip service'. Dollery (2008) suggest that local government reform is path-dependent and that specific change can be explained only by reference to circumstances unique to each area, while Oates notes "the degree of fiscal decentralisation is itself the outcome of complex political and economic forces" (Oates 1999, p. 1140). The case of separating trading from non-trading activities by establishing arm'slength entities, for example, has been actively pursued in New Zealand but not to the same degree in Australia, which lacks statutory vehicles for their establishment, such as CCOs and CCTOs. Similarly, privatisation has been adopted more rigorously in the United Kingdom, particularly in the Thatcher-led reforms, than in either Australia or New Zealand local government systems, although it has been an underpinning theme in both these countries. 
The key elements of the modernisation agenda were generally in place by the end of the nineties or had been rejected for political or philosophical reasons. In the last decade more emphasis has been placed on the outcomes of public policy and the general well-being of communities and citizens and less on the nature of the institutional machinery. This new emphasis is captured in legislation, like the United Kingdom's Local Government Act 2000 and New Zealand's LGA 2002, both of which contain broad statements of purpose emphasising well-being and the principle of sustainability. In the United Kingdom, since the 2000 local government act, modernisation has generally been concerned to achieve five objectives: improvements in local services; more effective community leadership; increased accountability; greater local stakeholder engagement; and improved public confidence in local government (Communities and Local Government 2009). Despite this broadening of the reform agenda, one theme continues to influence public policy towards local government, the suggestion that there are often too many councils and, in relation to New Zealand, that the process of consolidation never went far enough.

\section{Consolidation}

One persistent issue for local government reform is that of consolidation and the widespread view that 'bigger is better' and that larger councils are more efficient. The process is almost ubiquitous, with Queensland, for example, undergoing a systematic programme of consolidation in 2008 and Western Australia currently undertaking a similar process, although the rationale may vary, with Queensland placing more emphasis on strategic capacity while Western Australia appears to place more emphasis on the issue of efficiency. The release of the Royal Commission on Auckland Governance's report has also prompted calls for consolidation in other parts of New Zealand, such as the Wellington region and the West Coast of the South Island. However, there is no consensus on the relative merits of smaller or larger authorities. Oates (1999) states that, while the evidence is mixed, it can be argued that the influence of citizens increases as the size of government declines. His suggestion, that size has a negative correlation with effective democracy, is reinforced by Allan (2003), who argues that the value of smaller councils lies in: 
- better access to elected members and officials

- better knowledge of local conditions

- more political attention to local issues

- cost consciousness

- fewer hierarchical administrative structures

- more likelihood of an open culture.

The data, to the degree that it exists, also fails to support the 'big is cheaper' argument (see Figure 6).

Figure 6 Council expenditure by head of population

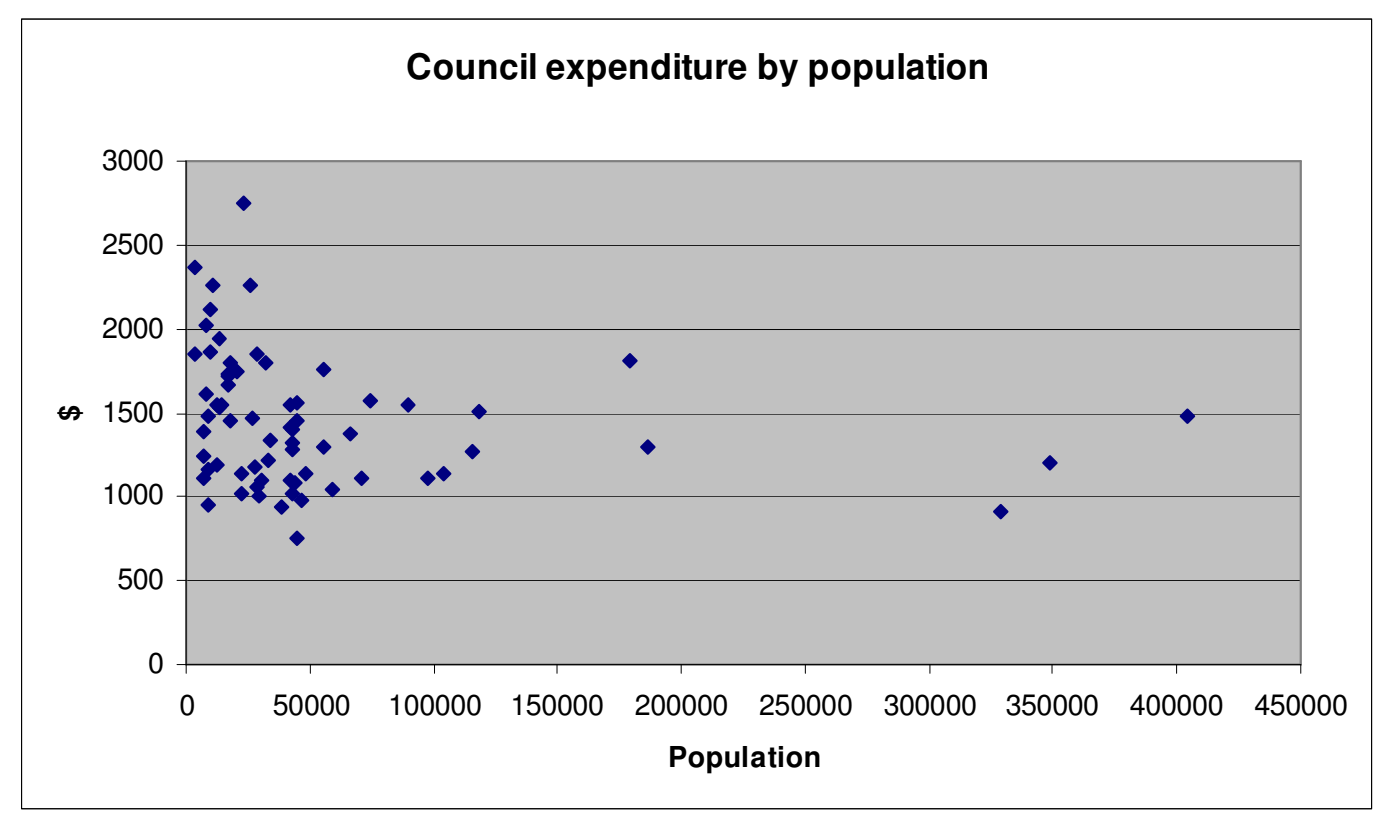

(Source: www.localcouncils.govt.nz ${ }^{54}$ )

Using a simple formula which divides total council expenditure by the normal resident population, Figure 6 provides an opportunity to identify whether patterns exist that might suggest a correlation between the cost of running councils and their size. The argument for consolidation is based on the

\footnotetext{
54 Population data is drawn from the 2006 census and council expenditure data is drawn from the 2009 Statistics New Zealand survey.
} 
assumption that serving greater populations allows for economies of scale by sharing overhead costs across a greater number of taxpayers. However, the evidence from Figure 6 fails to support such conclusions. Large councils tend to be clustered around the $\$ 1,500$ per person band for annual rates, whereas medium-sized councils, those with a population of around 50,000, tend to be clustered at a lower figure. What is most interesting about the data is the fact that some of the country's smallest councils are also its cheapest to run.

Balancing intimacy against efficiency is a classic problem of organisational design, where attempts are made to align administrative boundaries with the area of benefit flowing from council services. Yet councils are multi-purpose organisations and their various 'businesses' will have different areas of benefit. For example, while local parks will tend to benefit residents in particular neighbourhoods, something like economic development will inevitably benefit a larger area. Oates' solution to this issue, the problem of reconciling political jurisdictions with services with differential areas of benefit, involves multi-tiered forms of governance (Oates 1999). For example, regional governments are preferred because they are able to encompass watersheds and catchments as well as other environmental resources, and metropolitan governments are seen as a way to bring together central cities and suburbs, while smaller local governments are seen to allow residents to determine those services directly relevant to their own needs that are of a local scale.

\section{Central government steering}

The degree to which relationships are collaborative partly depends on the way in which central governments go about 'steering' their local governments. This is particularly salient in regimes, like New Zealand, where local government is a creature of statute and draws its authority from legislation enacted by the national parliament.

Steering, as the metaphor suggests, concerns the mechanisms higher authorities use to direct and influence the policy and operational decisions made by their councils (see Dollery and Wallis 2001b). The range of mechanisms is heavily influenced by the nature of the relationship between the 
two spheres of government. Montin (2000) suggests central-local government relationships can be conceptualised as sitting somewhere on an 'autonomy/integration' spectrum (see also Loughlin 1986). Where local government systems sit on this spectrum has a direct bearing on the type of mechanisms higher level governments are likely to employ when wishing to direct or steer local authorities, that is, their method of supervision. ${ }^{55}$ These mechanisms range from the strongly prescriptive, involving nationally defined performance, such as the English comprehensive performance assessment approach, ${ }^{56}$ to more negotiated approaches, such as regular meetings between governments and local government associations. Governments have access to a wide range of steering mechanisms (see Table 12).

Steering mechanisms characterised by medium and high prescription tend to apply to councils that sit at the integrational end of the autonomy/integration spectrum. Tightly prescribed performance standards, tied funding, national standards and recentralisation generally act to diminish local autonomy and emphasise national control, at least for defined services. Some, such as ratecapping, are blunt instruments which not only limit local governments' discretion to respond to community needs and preferences but can also lead to gameplaying by both local and national politicians. Game-playing results when politicians exploit accountability vacuums to blame each other for any governance failures, such as the failure to invest in infrastructure. Councils at the autonomist end of the spectrum tend to reflect steering approaches which strengthen voice and transparency, both measures increasing the understanding and influence of local citizens with regard to council affairs.

\footnotetext{
${ }^{55}$ While not within the scope of this project the range of accessible instruments will also be affected by other factors such as the constitutional status of local government.

${ }^{56}$ At the time of writing, the government had announced the creation of a new approach to local performance measures in which the more than 1,000 specific output targets were to be replaced by approximately 100 outcomes type targets (see www.dclg.gov.uk).
} 
Table 12 Central government steering mechanisms

\begin{tabular}{|c|c|}
\hline Strategy & Effect on local discretion \\
\hline Measures to increase transparency & Low \\
\hline $\begin{array}{l}\text { Accrual accounting } \\
\text { Annual plans } \\
\text { Explicit performance targets } \\
\text { Funding policies } \\
\text { Long-term financial plans }\end{array}$ & \\
\hline Measures to strengthen voice & Low/medium \\
\hline $\begin{array}{l}\text { Public access to information } \\
\text { Public access to meetings } \\
\text { Complaints procedures } \\
\text { Citizens' charters } \\
\text { Postal voting } \\
\text { Proportional representation/wards } \\
\text { Citizen-initiated referenda }\end{array}$ & \\
\hline Measures to standardise local services & Medium \\
\hline $\begin{array}{l}\text { National standards } \\
\text { Tightly prescribed performance standards } \\
\text { Direct central funding } \\
\text { Discretion to opt out of local control } \\
\text { Devolution to non-elected agencies } \\
\text { Recentralisation }\end{array}$ & \\
\hline $\begin{array}{l}\text { Measures to reduce local financial } \\
\text { discretion }\end{array}$ & High \\
\hline $\begin{array}{l}\text { Capping local rates } \\
\text { Shift to lump sum central grants (in place of } \\
\text { 'own source' revenue) } \\
\text { Nationalisation of business rates }\end{array}$ & \\
\hline
\end{tabular}

(Source: based on Dollery and Wallis 2001b) 
The nature of any steering mechanism will have a direct bearing on the ability of councils to exercise community governance. As Stoker notes:

the path to reform is not to allow local institutions complete autonomy or equally to imagine that the centre can steer the whole of government system. We need a form of central-local government relations that allows scope for all institutions to play an active role ... (Stoker 2005, p. 3).

In New Zealand's case the interventionist strategies employed are concentrated at the low to medium end of Dollery and Wallis' (2001b) prescriptive scale (medium to high end of the discretion scale), such as postal voting and freedom of information laws, both of which reflect strategies focused on increasing transparency and enhancing voice. However, since the passage of the LGA 2002 and the introduction of general empowerment there has also been greater use of 'medium' type intervention instruments of the standardising services nature, particularly in the environmental and public health area. For example, national policy statements and national environmental standards are apparently being developed by the Ministry for the Environment, ${ }^{57}$ a decision has been made to more actively employ the Minister for the Environment's call-in powers for projects of national importance, and a tendency has emerged to provide chief executives of central government agencies with the power to dictate employment conditions and professional standards for council staff undertaking devolved regulatory functions. ${ }^{58}$

\section{Local government taxonomies}

The previous discussion highlighted the different paths local government reform has taken and its association with history and ideological preference. The result is a diverse range of local government models with sufficient variety to encourage its own academic discipline as various writers have sought to find

\footnotetext{
${ }^{57}$ For an overview of the government's desire to establish greater central direction in the environment portfolio see www.mfe.govt.nz/rma/central/amendments/cab-paper-phase-two-reform.html.

${ }^{58}$ Examples include the Building and Control Act 2008, in which the chief executive of the Department of Building and Housing can directly override the authority of a council chief executive in the operation of a council's building control staff. Similar approaches are being considered for the Food Safety legislation and the review of the Health Act 1956.
} 
patterns by developing local government taxonomies. Taxonomies tend to classify forms of local government by levels of autonomy, central government relationships, strength of democracy, types of funding, and degree of citizen participation. However there is no common analytic framework, with taxonomies based on factors as diverse as countries' different histories, cultures, legal traditions and socio-economic conditions (Wolman 2008).

Alan Norton (1994) has attempted one of the more ambitious systems for classifying local government systems. Distinguishing 13 characteristics in his study of nine systems of local government, he has proposed five broad categories named after leading exemplars: British, North American, South European, North European and Japanese..$^{59}$ Among his key criteria is the constitutional base of the local government systems. European systems are more likely to be based on national constitutions while other systems tend to be empowered through acts of Parliament or covered by the mandate of subnational constitutions. The way local authorities receive their powers differs between those systems with a form of general competence and those whose powers are limited by higher statute. The proportion of public spending allocated to local government systems also varies significantly, as does the extent of participation by citizens, especially at elections.

While traditions overlap. Norton draws out two overall trends. One emerges from the tendency of southern and northern European societies to regard local government as an organic part of the community. These local government systems draw on the tradition of Roman natural law, frequently employing written constitutions to define their powers and derive legitimacy from local communities. Central and local government are seen as spheres, rather than levels, of government with complementary roles in what Norton describes as a collective tradition that seeks to build unity to avoid territorial fragmentation. Local government systems with a constitutional base operate with a greater level of certainty and guaranteed level of social rights than other systems and

\footnotetext{
${ }^{59}$ Norton's criteria are: constitutional status; national structure; powers; control of legality; control of local policy; control of local policy historically; local functions 1949-89; local authority expenditure of gross domestic product (GDP); public expenditure as a proportion of GDP; local executive authority; representation system; party system; and participation at elections.
} 
"provide, as it were, a philosophy within which central and local governments, and political parties, are expected to act" (Norton 1994, p. 16). In contrast, the Anglophone tradition, including New Zealand, is at once more instrumental and more pragmatic and councils are seen as just one of a number of local agencies competing for the right to deliver services. ${ }^{60}$ In this tradition, powers are not usually defined constitutionally and the extent of council authority is more dependent on the goodwill of their parliaments. The collectivity of the European models is replaced by an active individualism in which the default position is laissez faire and competition between councils is more pronounced.

Using a different set of criteria Andrew and Goldsmith (1998) and John (2001) distinguish between Northern European and Southern European models of local government. The southern group is characterised by a form of political localism in which communitarianism is an important feature. This involves a strong sense of collectivity which brings the centre and locality together, enabling the national representation of local issues. In contrast, the Northern European model, which includes Britain and the Netherlands, places more emphasis on legal localism and more value on local self-government and decentralisation. John (2001) notes that Northern European councils have become more institutionalised than their Southern European counterparts as a result of the larger role they have played as providers of welfare-state services. In Southern Europe these services tend to be provided directly by the state without the consequential institutionalising effect on local government. New Zealand does not feature directly in either of their typologies although it is likely to be viewed as being close to the British, and therefore Northern European, tradition.

In contrast to the more abstract or high level nature of these models, Shah (2006) has developed a descriptive typology which offers 10 alternative models of local government. In brief, these are:

\footnotetext{
${ }^{60}$ A pertinent example might be the nascent interest expressed by members of the Blair Labour government towards what they called "double devolution" - the passing down of responsibility for running services directly to citizens' organisation, bypassing local authorities altogether.
} 
- the Nordic model, in which local authorities provide most of the functions of the state, possess considerable autonomy and are mostly small and self-financing

- the Swiss model, which has long historical roots and enjoys considerable levels of local autonomy in areas including education, social welfare, energy, roads and local taxation

- the French model, a 'dual supervision' approach, in which local authorities have little local autonomy and there is a strong chain of command between councils and departments of the state

- the German model, which balances co-operation, subsidiarity and centralised policy-making with local service delivery

- the British model, which limits the role of local government, has large local authorities with little discretion and strong vertical fiscal imbalance

- the Indian model, which is a largely centralised model

- the Chinese model, in which local and provincial government are an integral part of the national administration and large councils deliver services on behalf of the state

- the Japanese model, which combines the central control found in the French version and the delegation of the German model

- the North American model, in which generally small councils have a degree of autonomy but can be dominated by state legislatures and the services provided can vary from services to property to education

- the Australian model, in which councils are primarily focused on the delivery of local services. Functional responsibilities are limited compared with other jurisdictions and the proportion of public expenditure is less than 5 per cent. (The Australian model incorporates former British colonies such as New Zealand and Canada.)

In relation to the challenge of developing taxonomies, Shah argues that there is not yet any uniform approach to the design of local government systems which takes into consideration size, structure and functions, although he notes that 
finances generally follow functions, and accountability to residents is a strong and underpinning principle. His failure to find high level generic patterns among different local government jurisdictions is explained by Norton's (1994) argument that local government systems are path-dependent. Each system is seen as being the result of pragmatic developments in response to "wars, invasions, revolutions, political pressures, evolving and conflicting concepts and values, economic and social demands ... and the state's efforts to promote economic growth and counteract unemployment and other contingencies" (Norton 1994, p. 22). He describes the process whereby the frameworks governing local government powers and responsibilities are subject to constant reshaping by unpredictable forces as a dialectic one, with the result that the history of local government is one of tension, with periods of relative local autonomy followed by periods of relative central control (ibid). As Coaffee notes:

tension exists between centralising focus and constructing prescribed policy at national site level, and decentralising power and responsibility to a more inclusive group of stakeholders in order to develop increasingly nuanced and locally specific sets of regeneration priorities and outcomes (Coaffee 2005, p. 108).

In contrast to the largely country specific typology of Shah, Aberbach and Christensen (2003) distinguish three broad categories of local government systems: individual-economic, collective and pluralist. The individual-economic model, which is similar to Norton's Anglophone category, reflects a dominant policy concern by the state with creating a system of local government that enhances individual self-interest and strengthens overall efficiency. In contrast, the collective model stresses cultural integration, that is, a sense of social cohesion and identity and a collective view of the state and its parts. With its emphasis on communitarian values and an organic approach to local central relationships, it compares with Norton's continental model. The individualeconomic model is distinguished by a preference for market-style instruments, defines the political role as primarily frame-steering (steering by remote control) and emphasises the role of citizens as economic actors. The collective model is characterised by more traditional notions of citizenship, shared values and a 
sense of "belonging to a collectivity with a common heritage and common future" (ibid, p.15).

In addition to the individual-economic and collective models, the authors identify a third and emerging model of local government, which they describe as a pluralist model. The pluralist model recognises the heterogeneous and mobile nature of communities, and their increasing institutional variety, as well as the way in which the democratic base has been strengthened by "encompassing more actors and interests in a participatory style, thereby creating more legitimacy than might result from a more centralised and controlled process" (ibid, p. 2). This emerging model acknowledges an environment with multiple power centres in which public policy is ultimately ambiguous and less coherent than in either the individual-economic or collective approaches. Aberbach and Christensen's plural model is the nearest any of the classification systems come to recognising the trend towards community governance. It shares many of the characteristics of a community governance approach, such as its emphasis on community participation and institutional variety.

\section{Taxonomies and the New Zealand system}

With regard to its size and constitutional status New Zealand local government contains a number of the core elements found in Norton's Anglophone tradition, particularly in the period between 1989 and 2002. The Anglophone pattern reflects similarities with New Zealand in terms of constitutional status and common law origins. The fit, however, largely depends on the criteria on which the taxonomy is constructed. Shah, for example, defines a separate category in his schema for the Australian system of local government, defining it as a system which has limited functional responsibilities and therefore low levels of expenditure in relation to the state. Using functions and expenditure as criteria it is clear that New Zealand and Australia are relatively unique.

A key feature of the New Zealand system of local government, also shared by systems in Australia, Canada, South Africa and to a degree the United States, is the country's history of colonisation and the role of settler society. In these countries, local government's origins were largely instrumental and councils 
were established to ensure new settlers had the necessary infrastructure to create functioning communities. The demands of development, however, were such that the state was required to play a more proactive role than in the established European democracies. Certainly in New Zealand, Australia and Canada the general weakness of local government (in terms of size and access to resources) meant that they lacked the capacity to undertake the investments needed for more complex policy interventions, such as health services, and higher level governments ended up playing a more prominent role.

Aberbach and Christensen's (2003) taxonomy, while high level, allows us to categorise changes to the New Zealand system in 2002. Before the LGA 2002, the New Zealand local government system largely reflected the classic exemplar of the individual-economic type of council. However, post LGA 2002, the most relevant category is probably their emerging pluralist category. The new emphasis on inclusivity, sustainable development and integrated approaches to decision-making, such as a softer central government interface, represents a move away from the instrumental bias found in the individual economic model and a move to a more plural approach. However, classification systems are inherently dynamic, councils change and models will generate findings based on the criteria applied. Cheyne (2008), for example, argues that the effect of the LGA 2002 in New Zealand and the modernisation agenda in the United Kingdom has been to shift the two systems towards the Northern European approach.

\section{Conclusion}

Local government theory provides a comprehensive explanation of the role of local government from both an economic and political perspective. Its theoretical contribution to economic welfare and democratic participation is clear; however, policy is seldom driven by theory alone. The history of local government reform highlights the influence of rhetoric and popular ideas that might have more to do with promoting the political careers of particular politicians than finding optimal governance arrangements for regions and localities. Local government reform in New Zealand can be seen as reflecting 
the way in which theory has influenced policy settings and framed debates as well as acknowledging the influence of political expediency and the role of individual actors with their own particular preferences. 


\section{Chapter 5 Community planning and governance}

This chapter summarises and analyses research into community planning undertaken by a sample of local authorities. It concludes by distinguishing those councils which approach community planning as primarily a compliance requirement (and interpret the legislation in a minimalist manner) and those which regard it as providing a mechanism for delivering community governance.

The topic of the thesis concerns the concept of community governance and how well positioned New Zealand councils are to achieve it. While the community governance assessment model in Chapter 7 is the primary tool for undertaking this assessment, the way councils undertake community planning also affords a useful insight. Community governance theory places considerable weight on councils engaging with citizens in order to set strategic direction for their localities in both an inclusive and collaborative manner. As described in Chapter 2, the LGA 2002 enhanced council long-term planning by requiring councils to facilitate a process to identify community outcomes, a process that some commentators have described as community planning (see Local Futures 2006) or community strategic planning (see McKinlay 2006). Others regard it as community governance in practice (see Leonard and Memon 2008). Compared with traditional or organisationally based strategic planning, this new approach treats strategy as being concerned with community-identified outcomes and the needs of the locality as a whole.

In relation to international approaches to community planning, such as the community-style planning undertaken in the United Kingdom and Ireland, the New Zealand legislation allows substantial variety in the way implementation is undertaken. Other than what was developed by the local government sector itself, little official guidance has been provided regarding how councils should undertake their planning responsibilities and the legislation is written in such a way that considerable discretion is allowed. Consequently councils' approaches to community planning reflect considerable innovation and diversity. 


\section{Research approach}

This chapter draws on analysis by Local Futures, a publicly funded research initiative which examined local government strategic planning over a five-year period beginning in 2004. In order to examine the way councils were undertaking their second LTCCPs (the second LTCCPs were to be adopted by 30 June 2006), a sample of nine councils was selected, representing a mix of rural and urban, North and South Island authorities. A small team of researchers was commissioned to interview officials, with a focus on identifying changes and improvements made since the adoption of their first LTCCPs and documenting the way councils undertook their community outcomes processes. The author was a member of the research committee that oversaw the research and was involved in setting the parameters of each case study. This chapter draws on the unpublished reports of those researchers. The nine councils chosen for the sample were:

- Waitakere City Council

- Manukau City Council

- Porirua City Council

- Auckland Regional Council

- Grey District Council

- Otago Regional Council

- Wellington City Council

- Dunedin City Council

- Marlborough District Council.

The selected councils were part of a larger sample of councils studied by Local Futures and were selected to ensure diversity in terms of size, location and socio-economic influences, as well as exhibiting a range of experiences with their approaches to strategic policy and planning (see Table 13). 
Table 13 Sample council characteristics ${ }^{61}$

\begin{tabular}{|l|c|l|l|}
\hline \multicolumn{1}{|c|}{ Council } & $\begin{array}{c}\text { Populatio } \\
\mathbf{n}\end{array}$ & \multicolumn{1}{|c|}{ Type } & \multicolumn{1}{|c|}{ Characteristics } \\
\hline $\begin{array}{l}\text { Waitakere } \\
\text { City Council }\end{array}$ & 201,300 & City: North Island & $\begin{array}{l}\text { Fast-growing, multi-cultural } \\
\text { city }\end{array}$ \\
\hline $\begin{array}{l}\text { Manukau City } \\
\text { Council }\end{array}$ & 361,900 & City: North Island & $\begin{array}{l}\text { Fast-growing, very multi- } \\
\text { cultural city }\end{array}$ \\
\hline $\begin{array}{l}\text { Porirua City } \\
\text { Council }\end{array}$ & 51,000 & City: North Island & $\begin{array}{l}\text { Medium-sized city with } \\
\text { diverse population }\end{array}$ \\
\hline $\begin{array}{l}\text { Auckland } \\
\text { Regional } \\
\text { Council }\end{array}$ & $1,414,700$ & $\begin{array}{l}\text { Regional: North } \\
\text { Island }\end{array}$ & $\begin{array}{l}\text { Largest regional council, } \\
\text { major issues around land } \\
\text { use and public transport } \\
\text { needs }\end{array}$ \\
\hline $\begin{array}{l}\text { Grey District } \\
\text { Council }\end{array}$ & 13,650 & $\begin{array}{l}\text { District: South } \\
\text { Island }\end{array}$ & $\begin{array}{l}\text { Small town recovering from } \\
\text { years of declining } \\
\text { population and investment }\end{array}$ \\
\hline $\begin{array}{l}\text { Otago } \\
\text { Regional } \\
\text { Council }\end{array}$ & 203,500 & $\begin{array}{l}\text { Regional: South } \\
\text { Island }\end{array}$ & $\begin{array}{l}\text { A narrow focus on } \\
\text { environmental management } \\
\text { regulatory roles }\end{array}$ \\
\hline $\begin{array}{l}\text { Wellington } \\
\text { City Council }\end{array}$ & 192,800 & City: North Island & $\begin{array}{l}\text { A wealthy city seeking to } \\
\text { redefine itself as a creative } \\
\text { hub }\end{array}$ \\
\hline $\begin{array}{l}\text { Dunedin City } \\
\text { founcil }\end{array}$ & 123,000 & $\begin{array}{l}\text { City: South Island } \\
\text { Generally static with little } \\
\text { population growth }\end{array}$ \\
\hline
\end{tabular}

\footnotetext{
${ }^{61}$ Estimated population for 2008; source www.stats.govt.nz.
} 


\begin{tabular}{|l|l|l|l|}
\hline $\begin{array}{l}\text { Marlborough } \\
\text { District }\end{array}$ & 44,500 & $\begin{array}{l}\text { Unitary: South } \\
\text { Island }\end{array}$ & $\begin{array}{l}\text { A unitary council in a } \\
\text { Council }\end{array}$ \\
& & $\begin{array}{l}\text { community that has become } \\
\text { increasingly diverse as a } \\
\text { result of changing land use } \\
\text { (wine industry) }\end{array}$ \\
\hline
\end{tabular}

(Source: www.localcouncils.govt.nz)

The sample ranges from large urban to small rural councils and includes one unitary authority and two regional councils; however, it is not representative of the whole sector and, as Table 14 shows, the sample is heavily weighted to large urban councils. To be representative, the number of small rural councils would need to be increased, but this would have diminished the ability to analyse relevant case studies as few, if any, of the small rural councils sought to exploit the community governance potential of the community outcomes framework.

Table 14 Sample population as proportion of total population

\begin{tabular}{|l|l|l|}
\hline & Population & Sample \\
\hline Number of councils & 83 & 9 \\
\hline Proportion of cities & $20 \%$ & $55 \%$ \\
\hline Proportion of districts & $60 \%$ & $12 \%$ \\
\hline Proportion of unitaries & $5 \%$ & $11 \%$ \\
\hline Proportion of regionals & $14 \%$ & $22 \%$ \\
\hline
\end{tabular}

The non-representational sample has been adopted due to the objective of the study, which is to distinguish the nature of weak and strong community governance as opposed to summarising the practice of the sector as a whole. It is surmised, and the results of Local Futures' research back this up (Local Futures 2006), that larger urban councils, such as Manukau City Council, have invested significantly more in their community planning exercises than smaller councils (not just in real terms but also proportionally), with many of the latter 
having barely complied with the letter of the legislation. Also, if the intergovernmental aspects of the model are to be examined, the emphasis will need to be on urban communities, as urban problems tend to be an ongoing governmental focus, particularly those communities where social problems are more pronounced, such as Porirua City and Manukau City. ${ }^{62}$ Interviews were undertaken with local authority staff during 2008 and also covered preparation for the 2009-2019 LTCCP. Some councils (those that had been early compliers with the LGA 2002) were undertaking reviews of their community outcomes, while others were simply refining the existing strategic frameworks and focusing on organisational alignment.

\section{Community planning: the process}

The community outcomes process is a requirement of s73 of the LGA 2002, under which all councils are required to facilitate a process to identify community outcomes at least once every six years. Councils' LTCCPs, which are reviewed every three years, not only describe these outcomes but indicate how the councils' activities will contribute to their achievement. While almost all councils had a history of developing strategic plans before the LGA 2002, particularly since 1989, these new provisions were different. Unlike traditional strategic plans, which tend to be organisationally focused, the focus of the new framework was outcomes for the community as a whole. Councils were no longer to determine the direction of their communities; they were to follow. This has thrown up a number of issues, both theoretical and practical.

One of the findings of these case studies, which were consistent across the sample, revealed that councils with a history of strategic planning experienced fewer problems with the new provisions than those without any such history. Indeed some, such as Manukau and Waitakere, felt the LGA 2002's provisions were essentially inferior to their previous approaches to strategic planning. Both councils were at the forefront of good practice, particularly with respect to

\footnotetext{
${ }^{62}$ Interviews by the author with officials from both Manukau and Porirua councils reveal that neither authority finds difficulty engaging with government agencies, many of which located themselves in these cities. In contrast, rural mayors frequently complain of the difficulty of attracting the interest of those same departments.
} 
collaboration with other stakeholders and community engagement, and both had invested extensively in strategic planning before the new legislation was enacted. Unlike much of the pre-LGA 2002 strategic planning, Waitakere and Manukau were more outward focused and took what could be described as a strong community governance approach - their strategic plans were about achieving outcomes for their communities rather than councils and both were engaged in ongoing conversations with other stakeholders over city-wide issues. $^{63}$

Manukau developed a collaborative multi-sector process branded as Tomorrow's Manukau (see www.tomorrowsmanukau.co.nz), which was as much about the process of stakeholder collaboration as about strategic planning. Underlying the council's approach was a realisation that many of the issues facing the city (particularly the social issues) could not be addressed by any single agency. Consequently the council sought to increase its effectiveness in these areas, particularly in relation to social outcomes. Seventy agencies were initially involved in Tomorrow's Manukau with the key partners being the Ministry of Social Development, the District Health Board, Housing New Zealand, the Ministry of Pacific Island Affairs, Te Puni Kokiri (the Ministry of Maori Development), the New Zealand Police and Manukau Institute of Technology.

The original Tomorrow's Manukau document had a vision of 'Progressive, Proud and Prosperous' and included seven themes or outcome areas which included the themes of 'Safer Communities' and 'Vibrant and Strong Communities' (ibid). The process was led by a steering group that was responsible for developing, co-ordinating, overseeing and monitoring the development of the vision. An inter-agency group and champions were established for each outcome area, with participating agencies expected to prioritise these outcomes in their work programmes. While the level of agency commitment may have been variable, Tomorrow's Manukau was seen to be an

\footnotetext{
${ }^{63}$ Manukau's approach was well known to officials drafting the LGA 2002, who sought to replicate many of its features in that statute.
} 
important step in building trust-based relationships and practical community governance.

Waitakere City Council's 'Eco City' vision, based on the principles of Agenda 21, has guided its strategic planning since 1993 and during this period the city had become internationally known for its sustainability initiatives. Community engagement was regarded by the council as a cornerstone of its approach with the council playing the role of broker when faced with difficult issues. Strong community and stakeholder involvement involved the use of innovative techniques like charettes. By the end of the nineties the council began to adopt a similar approach to that used by Manukau City Council, particularly working with key stakeholders to address social and environmental issues. The flagship project, the Waitakere Well-being Project, brought together a range of social and health sector groups to address social issues in the city. In comparison with Manukau's emphasis on engaging with government departments, Waitakere tended to emphasise engagement with not-for-profit organisations and the wider community. Waitakere's approach was regarded as more grass-roots than Manukau's, which tended to focus on formal partners who had influence over the allocation of financial resources.

Porirua City's experiences were similar to both Manukau and Waitakere in that it had a tradition of innovative strategic planning to call on. Its first community outcomes process was undertaken in 2003, which meant that the council was required by law to undertake a review in time for the 2009-2019 LTCCP. A joint steering group consisting of council members, government departments and the community was formed to oversee the process. The initial process involved 110 community groups and organisations and resulted in seven outcomes, which were prioritised by the council and grouped into the four elements of well-being. The 2009 LTCCP, in contrast, placed greater emphasis on the development of action plans to implement the outcomes.

Wellington City Council was also able to draw on earlier strategic planning exercises when it identified its first tranche of community outcomes in 2003. The council's process resulted in 43 outcomes, none of which were prioritised. Two 
years later they repeated the process, seeking the views of 190 stakeholders and groups (only 36 responded). The process had a number of components:

- Council staff compiled key issues as identified by 20 key agencies and six focus groups of residents.

- These issues were then considered by a representative public review panel (20 members). The panel formulated draft community outcomes.

- The draft community outcomes were subject to media and public consultation.

- After consideration of 122 submissions, 45 community outcomes were set by the panel.

When attempting to set strategic directions the council found the resulting multiple outcomes unhelpful and further grouped them into 13 council outcomes, around which a number of high level council strategies have since been developed. These strategies were introduced to achieve greater internal alignment and counteract the tendency towards silos within the council organisation as well as help councillors focus on longer term outcomes. Strategy trees have been developed to show the connections between outcomes and council activities.

The Marlborough District Council developed its first set of community outcomes in 2005, adopting 13 outcomes, which were effectively 'rolled over' into the 2009-2019 LTCCP. Rather than review the outcomes through its most recent LTCCP, the council decided to focus on strengthening internal alignment between its identified outcomes and its organisation (see Figure 7). The council was, however, involved in a review of its Regional Policy Statement (a statement of regional environmental standards primarily concerned with water and air quality, as required by the RMA 1991), which provided an opportunity to rethink some of its high level outcomes. Figure 7 also shows the way in which this council attempted to use the outcome model to achieve alignment with other agencies, both around outcomes and in relation to activities undertaken. 
Figure 7 Marlborough's outcome planning framework

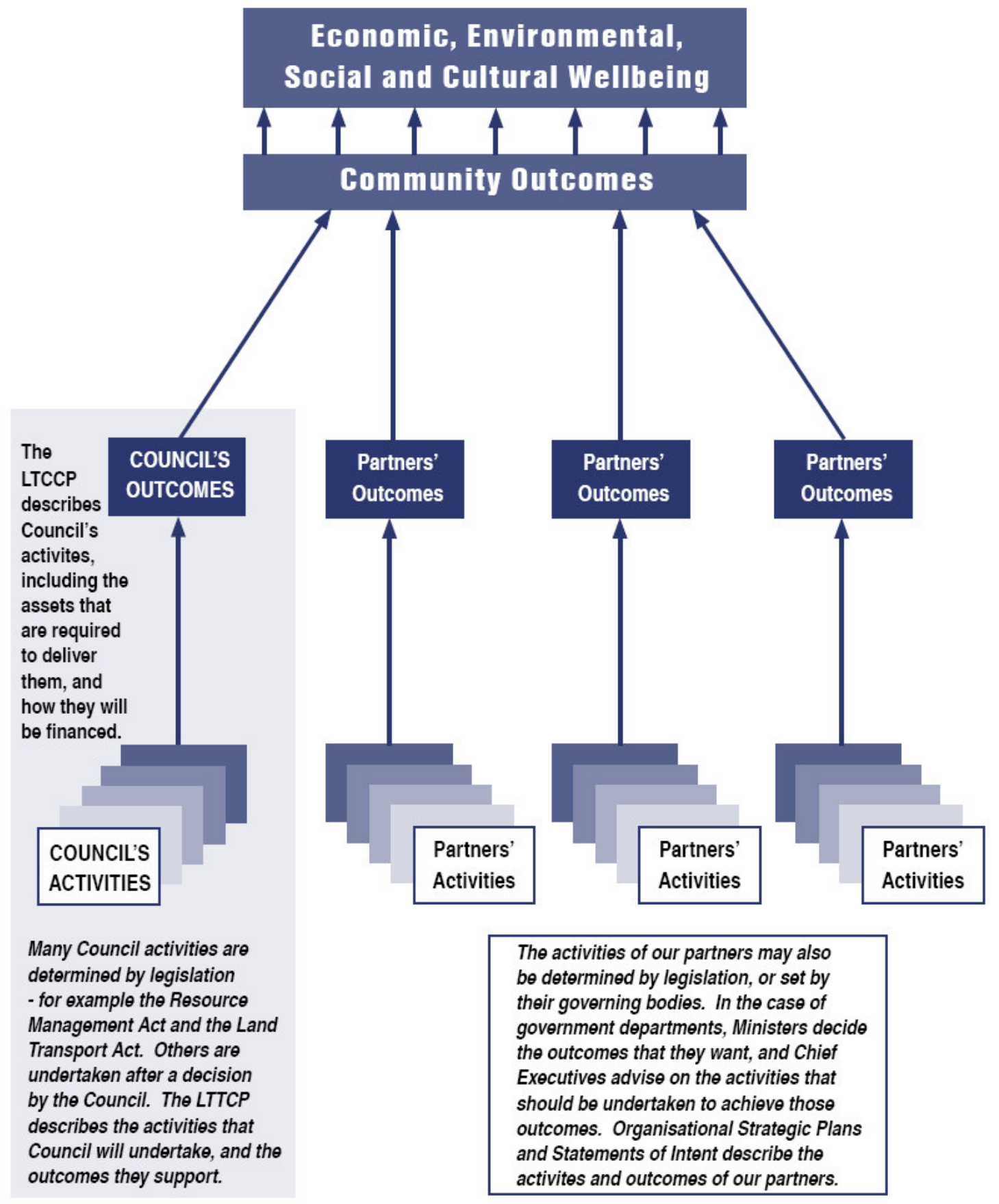

(Source: http://www.marlborough.govt.nz/content/docs/ plans\%20and\%20reports/Volume_1_FINAL_22_06_09.pdf)

The alignment within Marlborough's planning framework reflects the advice councils have received from the Office of the Auditor-General (OAG). Community outcomes sit in a framework of objectives, plans and measures which, while not in statute, have similar authority as they are subject to 
guidance provided by the OAG. The nature of this guidance is described in Table 15.

Table 15 What the auditors were looking for

\begin{tabular}{|l|l|}
\hline LTCCP component & Analysis/Assessment \\
\hline Well-being & Vires test \\
\hline Community outcomes & Strategic choices and trade-offs \\
\hline Rationale for activities & $\begin{array}{l}\text { How the activity contributes to well- } \\
\text { being/outcomes }\end{array}$ \\
\hline Levels of service & $\begin{array}{l}\text { Attributes that the service influences or } \\
\text { provides }\end{array}$ \\
\hline Measures & $\begin{array}{l}\text { How the effect on attributes will be } \\
\text { assessed }\end{array}$ \\
\hline Targets & The level of performance sought \\
\hline
\end{tabular}

(Source: OAG 2008)

As interpreted by the Auditor-General, the process is both strongly linear and cascading. Dunedin City Council's LTCCP is a good example of this in practice for the way in which its seven community outcomes are each aligned with a separate well-being area. In addition to the LTCCP, the council's State of the City report has been analysed to give an overall assessment of the effectiveness of the linkages between council activities and community outcomes. Like a number of councils, Dunedin City Council came to its first community outcomes process with a background in strategic planning. Its first outcomes were identified in the 2003/04 year, with the council settling on seven. These were grouped under four themes which also related to divisions within the council's 10-year budget, namely, economic well-being, environmental wellbeing, social and cultural well-being, and organisation. The council has noted a change in orientation since that time. In 2003 the focus was largely on the direction, form and development of the city, and in 2006 there was more concentration on the city council's role as facilitator, while in 2009 the focus shifted to addressing sustainability issues. Community outcomes were developed through the maintenance of: 
programmed dialogue with a range of institutions, groups and individuals....known as the 'city stakeholder process' [which] includes community groups, Maori, non-governmental agencies, business, other local authorities and some government departments (Dunedin City Council LTCCP Vol. 1, p. 32).

A range of specific tools was used to facilitate the city stakeholder process, such as well-being forums, community focus groups and annual residents' opinion surveys. The DCC also runs an 'Expo' as part of its consultation for the triennial LTCCP, which is a type of open house consultation exercise that it offers as an alternative to traditional public meetings. The DCC highlights a number of roles for itself in the outcomes process, a key role being that of facilitator. It does this by ensuring that the community is consulted on the development of the outcomes, for example, through annual well-being forums. Other roles include service provision, funding, planning, and a range of capacities, including leader, partner and stakeholder.

The Otago Regional Council's LTCCP has six community outcomes which are notable for not being clearly associated with specific well-being areas. Each outcome is linked to key actions and measures, representing a cascading relationship of outcome - action - measure. They described their community outcomes process as "providing opportunities for the Otago community to discuss its desired outcomes in terms of the future social, economic, environmental and cultural well-being of Otago" ( ORC Draft LTCCP 2009-2019, p. 9). This is one of few specific links to the well-being purpose of local government in its LTCCP, although it is strongly qualified by a narrow definition of role:

It is important to understand that whilst this Council has identified the outcomes for Otago, it is not responsible for achieving all of those outcomes. For example, this Council will not undertake work that is the responsibility of the health sector, NZ Police and other organisations (ibid). 
While the council notes that community outcomes can guide decisions made by other agencies, it failed to elaborate on which agencies might be relevant. Given that ORC identifies climate change as one of its key issues for the future, which as a 'wicked issue' cannot be managed by one agency alone, it is surprising the council's LTCCP has so few references to collaboration.

When faced with the requirement to identify community outcomes, regional councils faced a somewhat different set of challenges. While issues arose with respect to the relationship of their processes with those undertaken by territorial authorities within their regions, and practice varied, most found that the LGA 2002 failed to fit comfortably with their other statutory responsibilities. The Otago Regional Council (ORC), for example, suggested that their councillors placed more emphasis on regional environmental planning processes, which range from water to pest management, than the LGA 2002. Most agreed that given the range of statutory planning functions for which regional councils have responsibility there was little value in going through the LTCCP consultation. The Auckland Regional Council, however, was in a particularly unique position as it sought to balance its regional council responsibilities not only with the community outcomes process and the LTCCP but also with a range of Auckland-specific planning responsibilities, such as the Regional Growth Strategy, Regional Land Transport Strategy, Auckland Regional Economic Development Strategy and the One Plan (designed to implement the Auckland Sustainability Framework).

\section{Defining the content}

Outcomes tended to reflect generic themes and some councils worked hard to identify linkages with the interests of other agencies. Manukau City Council found, by chance, that the statutory obligation to identify community outcomes coincided with a scheduled review of their Tomorrow's Manukau planning framework, the city's pre-LGA 2002 approach to community planning. Officials took the view that the broad themes of the original exercise were still relevant but that a more robust set of outcomes was needed and used the existing themes in Tomorrow's Manukau as the basis of their community consultation. 
The council developed a consultation strategy that operated at a number of levels and involved numerous public meetings, including a survey of approximately 1,000 participants. This was undertaken both to provide a wider public perspective and to understand the different preferences of the city's various population groups, including Maori. Council officers played a leading role in the consultation and involved the city's community boards. Leadership roles were given to government agencies and not-for-profits in order to organise and facilitate a range of consultations, particularly with marginalised groups. The objectives that emerged from the consultations were handed to the existing outcome groups for analysis and attempts were made to assess the community's intent and determine the practical effects needed to achieve that intent. The objectives became the new community outcomes published in a revised Tomorrow's Manukau. Each theme included a number of outcomes and targets (see Table 16).

Table16 Tomorrow's Manukau themes

\begin{tabular}{|l|}
\hline Educated, knowledgeable population \\
\hline Healthy people \\
\hline Moving Manukau \\
\hline Safe communities \\
\hline Sustainable environment and heritage \\
\hline Thriving economy \\
\hline Vibrant and strong communities \\
\hline
\end{tabular}

(Source: www.communityoutcomes.govt.nz)

Each of the city's community boards has also developed community-based strategies with outcomes that link to the city-wide version. For example, the Botany Community Board has, within the 'Healthy People' theme, given priority to the outcome of improving physical access to health facilities (Manukau City Council 2009) while the Clevedon Board has, within the same theme, prioritised reducing coastal water pollution from sewerage outfalls (Manukau City Council 2009). At the time of writing, council officials were looking at ways to improve the community's understanding of what is happening and how community 
outcomes are being implemented and have suggested that they expect community outcomes will become more organic and less fixed over time.

In preparation for their 2006-2016 LTCCP, Waitakere City Council officials set out to design a community-based process, based on their earlier ECO city platform, to develop a new set of outcomes. Using its existing outcomes as the starting point, officials developed a visual story to explain how the community had changed and presented this to a series of public meetings. Two panels of experts were set up to synthesise the information into draft community outcomes and 15 outcomes were endorsed, including specific outcomes for Maori. One of the two panels was appointed by Maori. The outcomes take the form of high level themes, each of which refers to a number of more specific outcomes (see Table 17). For Waitakere City Council the result of the 2006 process was remarkably consistent with the strategic goals adopted in its earlier pre-LGA 2002 strategic plan, reflecting perhaps both the membership of the panels involved and the influence of the council's leadership.

Table 17 Waitakere City Council outcome headings

\begin{tabular}{|l|}
\hline Green network \\
\hline $\begin{array}{l}\text { Mauri Ora (Access to Maori } \\
\text { resources) }\end{array}$ \\
\hline Nga Makukura (Maori leadership) \\
\hline Strong economy \\
\hline Strong communities \\
\hline Sustainable and integrated transport \\
\hline Sustainable environment \\
\hline Autonomy \\
\hline Health lifestyle \\
\hline Urban and rural villages \\
\hline Vibrant arts and culture \\
\hline Environment protection \\
\hline Participation in society \\
\hline Working together \\
\hline
\end{tabular}

(Source: www.communityoutcomes.govt.nz) 
Grey District Council is the smallest of the sample councils and the least resourced for strategic planning. It was also an early complier, identifying eight community outcomes in 2003. For the 2009-2019 LTCCP, community feedback was sought on the original outcomes, with residents being asked to rank them in priority and identify any gaps. By the end of the process, the 2003 statement was largely restated with greater weight given to the themes of opportunity, access and affordability. The council has worked closely with its neighbouring authorities and the outcomes were intended to be common along the West Coast.

The sample councils' first attempts to undertake community planning were varied, with some able to build on relationships developed in earlier exercises, while others literally started from scratch. One area that almost all councils found difficult was developing effective intergovernmental relationships with departments and Crown agencies.

\section{Strengthening collaboration}

Community governance emerged as a way of describing the role of local governments that were responding to the fragmented governing space left by local and central government reform in the United Kingdom. Although New Zealand has not been subject to the same level of fragmentation at the local level (in fact the first reform phase was characterised by the opposite, widespread consolidation), achieving outcomes was inevitably regarded as requiring collaborative initiative.

Dunedin City Council, having identified community outcomes through a conventional strategic planning process, set about determining which local and national agencies contributed to their achievement. For example, the outcome 'Supportive community', which emphasised a culture of volunteering, tolerance, diversity and participation in local democracy, was seen as the responsibility of a wide range of public and non-public agencies (see Figure 8). 
Figure 8 Dunedin: collaborating for outcomes

\begin{tabular}{|l|l|}
\hline Outcome & Our city is built on strong \\
\hline $\begin{array}{l}\text { A city where residents feel included } \\
\text { community }\end{array}$ & $\begin{array}{l}\text { communities. } \\
\text { - All volunteers feel valued. } \\
\text { - We are an ethnically diverse and } \\
\text { tolerant community. }\end{array}$ \\
- The people participate in our \\
representative democracy.
\end{tabular}

\section{Contributing stakeholders}

Work and Income New Zealand

Ministry of Social Development

Presbyterian Support

\author{
Dunedin Council of Social Services \\ Huirapa Runaka \\ Age Concern
}

In addition, the council's LTCCP Summary and State of the City report both highlight examples where the DCC works with agencies and stakeholders in furthering community outcomes. In contrast, the Otago Regional Council explicitly sought to constrain its own role; however, it did acknowledge the potential for community outcomes to guide decisions made by a range of agencies. In a section on working relationships the council's LTCCP states that:

the Otago Regional Council will work with our location organisations, Maori, Central Government and non-Government organisations, and the private sector, in furthering community outcomes (ORC 2009, p. 12).

While their statement mirrors the requirement in the LGA 2002, it provides no elaboration on how it will be achieved. It is perhaps another example of a largely compliance-driven approach. The council's description of agency roles emphasises functional accountability and an ultra vires mentality, that is, a reluctance to look beyond legislative duties. 
Porirua City reported that its relationships with central government agencies have developed and strengthened during the first six years of the LGA 2002 framework, shifting from being largely reactive to more of a full partnership (or more accurately a range of partnerships). The council is increasingly operating as co-ordinator for different inter-agency initiatives, with funding channelled from government agencies through the council - the council undertaking the management of contracts on behalf of the state as well as handling the monitoring and reporting roles. The council reports that relationships with departments are better than ever and include significant projects that have reallocated resources and resolved local issues. In their view the community plan and LTCCP provide a safe context that encourages risk-averse government agencies to work with them and operate in a community governance manner. Collaboration has also improved with other local authorities in the region, particularly through the Wellington Regional Strategy. This has been further strengthened by the willingness of central government agencies to push for a regional consensus when major funding decisions, such as roading and public transport, need to be made. As the example of Porirua indicates, the LTCCP process has provided a mechanism for government agencies to communicate with local government. Grey District, for example, has historically had few links with government departments but regarded its three social outcomes (health services, education and personal safety) as providing a platform on which these links might be enhanced and developed in the future, despite the limitations of being a small council with few resources. The council that had achieved the most buy-in by external agencies and consequently the strongest community governance was probably Manukau City Council.

Since 2006 Manukau City has continued to refine its strategic platform, Tomorrow's Manukau, which, at the time of the research, had the active participation of more than 70 agencies. The most recent iteration focused on major projects where collaboration had the potential to make a significant difference. Where the first version of Tomorrow's Manukau contained a list of actions reflecting what organisations were already doing, the second version included a workbook with detailed sets of targets allocated to participating 
organisations. Projects were assessed on the basis of their ability to contribute to outcomes and reflected the following priorities: reducing family violence, increasing participation in early childhood education, a Manukau arts festival, and place-based neighbourhood renewal. Each project has a project manager and specific implementation plan.

Most notable about these priorities is their broad scope and the degree to which at least two of them, family violence and education, are outside the traditional focus of the council's activities. Strong leadership is regarded as important and the council's chief executive has taken on a leading role in the process. Interestingly, the council found it took a number of iterations of Tomorrow's Manukau in order to develop goodwill and trust with officers, with a lack of trust between participants in the early years. Initially the process was seen as largely council-driven and less effective at redirecting or developing new agency responses.

The second iteration of Tomorrow's Manukau involved cross-agency teams which were responsible for redefining community outcomes and developing actions/responses to those outcomes. However, a problem of 'silos' arose, forcing the council to focus on more effective horizontal and vertical integration. To address this, the steering group was restructured so that it was seen as less of a council and more of a community-owned entity. In addition, its scope was redefined to provide more oversight and strategic leadership - such as ensuring that resources for collaborative action are focused around agreed key priorities. As an example of community governance in practice, Manukau City Council has established what it calls Tomorrow's Manukau Forums, each of which has an issue focus, such as youth or environmental sustainability. While trust between partnering agencies has grown, officials note some gaps in their collaborative strategy, with engagement stronger at the operational level than the policy level. Increasingly engagement with the Government has begun to operate at a regional level and the council has had to push to ensure that social issues remain on the table within the new regional Forums. 
In comparison, Waitakere has placed more emphasis on dealing with particular issues than with a detailed inter-agency work programme. For example, the Waitakere City Well-being Collaboration Project is a partnership between the city, local community organisations and central government agencies. Intended to sponsor collaborative projects which will enhance the well-being of the Waitakere City community, the project involves a memorandum of understanding (now a partnership agreement) between the council and five funding agencies, which has now been developed into a partnership agreement. Since 2002 the council has sponsored annual well-being summits which have been used to determine mandate and direction for the following year. It was expanded in 2005 to include economic well-being and a project called the Waitakere Skills and Employment Project was established. ${ }^{64}$

The council's enthusiasm for collaboration in the social policy area was partly motivated by a desire to access greater levels of national funding to address local community issues. The council found the fifth Labour government more than willing to engage, although officials commented that as the 2008 national elections drew near interest in such partnerships appeared to diminish as officials became risk averse at the possibility of a new political regime. Collaboration appears to have worked best in the social policy area, possibly due to the proactive stance of the Ministry of Social Development, with less success in other areas like transport and the environment.

The general success of Waitakere, Manukau and Porirua cities in establishing relationships with government agencies and a community governance approach was not widely replicated in the rest of the sample. A possible factor in their success might be the fact that all three councils have a history of working on local collaborations and a culture of concern with community issues not found in many of the other councils in the sample. Perhaps the other factor is that the demographics of all three cities, that is, young, multi-cultural and low socioeconomic status, make them a priority for government attention.

\footnotetext{
${ }^{64}$ The council's approach to partnerships is known colloquially as the 'Waitakere Way'. Similarly, Manukau City's particular approach to collaborative strategy is known as the 'Manukau Way'.
} 


\section{Analysis}

The LGA 2002 required councils to facilitate a process to identify the outcomes held by their 'communities', a form of community planning which is one of the defining features of community governance. How well New Zealand councils have implemented the framework and how well the framework measures up to international practice should give some insight into the strength or weakness of community governance in New Zealand councils and how enhancements might be designed.

While the majority of councils saw the community outcomes process as an additional compliance exercise rather than an opportunity to implement community governance, many have found unexpected value arising from the process. Marlborough District Council, for example, found the LTCCP helpful in focusing councillors on the big picture and avoiding short-term thinking and policy 'flip flops'. They regard their LTCCP as acting as a reference point enabling progress to be charted over time. Similarly, Wellington City Council found the LTCCP reinforced its three-year planning cycle and led to more strategic and less ad hoc decisions by the council's elected members. The organisation has also been better at working co-operatively in a more integrated manner. Grey District Council found that the process of reviewing its community outcomes confirmed to the council that it was heading in the right direction as well as providing a basis for collaborative discussions with its neighbouring authorities.

Some were less positive, with Dunedin City finding that the LTCCP had greatly improved process and financial management but that the framework failed to add value to technical performance, creative planning or to the council and councillors' leadership capability. The requirement, introduced in the LGA 2002 , that LTCCPs be subject to an audit opinion, was generally seen as driving a compliance mentality rather than encouraging councils to be creative and innovative. While councils designed and undertook a range of different consultative and information-gathering exercises to identify desired outcomes, the exercise was often controversial. Some councils, particularly smaller rural 
authorities, regarded it as an unnecessary compliance burden that added nothing to their capacity to provide good governance and indeed made their task more difficult by raising citizens' expectations. Reflecting on this new responsibility, the Mayor of the Hauraki District commented to the writer that the cost of identifying community outcomes and monitoring progress would only have value if government agencies agreed to adjust their local programmes in order to acknowledge local priorities and work towards their achievement. ${ }^{65}$

The sample of nine councils revealed a number of approaches that ranged from councils that saw the LTCCP as having the potential to develop community governance approaches to those that saw the exercise as simply another compliance burden. Table 18 reviews the sample against three of the community governance principles developed in Chapter 3 in order to identify those councils that sought to develop processes that might strengthen community governance. The principles are the degree to which the process was inclusive, promoted partnering and had an outcomes orientation. Council practice is ranked as low, medium or high for each principle.

Table 18 Analysis of community outcomes practice

\begin{tabular}{|l|l|l|l|l|l|l|l|l|l|}
\hline & Po & Mu & Grey & ARC & ORC & We & Dn & Mh & Wn \\
\hline Inclusive & High & High & Low & Low & Low & High & High & Med. & High. \\
\hline Partnerships & High & High & Low. & Low & Low & High & Med. & Low & Med. \\
\hline $\begin{array}{l}\text { Outcome } \\
\text { orientation }\end{array}$ & High & High & High & Med. & Med. & High & High & Med. & High \\
\hline
\end{tabular}

\section{Key}

Po Porirua; Mu Manukau; Grey Grey; ARC Auckland Regional; ORC Otago Regional; We Waitakere; Dn Dunedin; Mh Marlborough; Wn Wellington City.

${ }^{65}$ Private conversation at a rural and provincial mayors' meeting, Wellington, September 2006. 


\section{Inclusiveness}

The sample councils took varying approaches in achieving the inclusiveness principle. Regional councils took the most technical and least populist route to determining outcomes with the $\mathrm{ARC}$, for example, using a range of stakeholder groups to develop the initial set of outcomes, which were then polished and grouped by staff. ${ }^{66}$ The territorial councils were more participatory, with Dunedin City Council, for example, employing a broad range of consultative and inclusive mechanisms to identify community issues. It also established wellbeing teams of stakeholders, which met annually to review progress. Wellington City Council employed a process that was both inclusive and participatory, combining stakeholder involvement and public consultation.

\section{Partnerships}

It was in relation to the partnership principle that major differences in the experience of the sample councils emerged. Partnering was strongest in Porirua, Manukau and Waitakere councils and relatively weak in the majority of others. This highlights a critical weakness in the New Zealand approach to community planning, that is the lack of any binding obligation on central government departments to take part either in the process of identifying outcomes or in the follow-up process of achievement. The Government had specific policy objectives for working in those three communities, which suggests that interest in joined-up approaches may be driven more by public policy objectives than a desire to put a new model of public governance into practice. In addition these councils have a history involving an extensive range of inter-agency collaborations. In contrast, Grey District, while looking to engage with central government agencies around social, educational and health outcomes, has achieved little more than the sort of ongoing liaison that would be expected to exist without a community planning framework.

\footnotetext{
${ }^{66}$ Interestingly the council itself inserted an additional outcome which had received no support at all in the feedback received from their stakeholder consultation.
} 


\section{Outcome orientation}

The third principle is concerned with the degree to which the process has an outcome orientation. The majority of councils in the sample used a range of initiatives to identify the issues important to their citizens and develop an initial list of issues, such as stakeholder groups. These councils employed focus group techniques to develop the 'first cut' of outcomes, which was then used as a basis for more traditional public consultation processes. However, the result of this process was a set of outcomes that was very general and difficult to distinguish between cities and districts - the 'healthy, wealthy and wise' style of community outcome. Their high level and abstract nature raises questions about their suitability for building a community governance framework.

Practice among the sample councils ranged from approaches which began with a blank slate and built up outcomes on the basis of consultative practice to less ambitious exercises with some councils preparing a list of draft outcomes and seeking comment. While the blank page approach was favoured by advocates of the legislation (see McKinlay 2004) on the grounds that it represented the best way of reducing council influence on the nature of the outcomes, the sample councils were more likely to begin with existing outcomes and ask citizens if they still reflected their aspirations and priorities. In practice, council officials had considerable influence on the shape of the outcomes regardless of the approach taken. For example, even in the blank page approach it was left to council officials to take the survey results, consultation feedback and other data and frame the final high level outcomes. Issues of weighting and framing occur in the information consolidation phase of the process and anecdotal evidence indicates that some councils, including Wellington City Council, felt officials had more to do with shaping the outcomes than the community (which possibly explains why Wellington was one of the councils that did not try to aggregate outcomes into six to eight high level versions). Although the community outcomes process is an important instrument contributing to effective community governance, the case studies highlighted a number of issues. For example: 
- the different approaches taken to identifying the views and aspirations of citizens and the difficultly of ensuring the diverse voices of citizens have an opportunity to be heard. The New Zealand process is too easily 'captured' by officials and interest groups

- the variable capability and political commitment of councils, which resulted in some councils either not having or not allocating sufficient staff to develop innovative and inclusive processes. (This is not simply an issue of scale as some small councils, such as Opotiki, are highly regarded for both the quality of the LTCCPs and innovative practice.)

- the discretionary nature of central government involvement, which created a difficult asymmetry, with councils holding responsibility for facilitating the process and identifying outcomes but lacking the resources, capability or statutory means for resolving them.

Due to the manner in which the requirement has been drafted and the failure of the Government to extend the obligation to other parts of the public sector, the New Zealand approach to community planning has resulted in variable practice. Some councils have taken innovative approaches to developing community planning processes which are both collaborative and inclusive, while others, in contrast, saw it as largely a compliance exercise.

\section{Conclusion}

The concept of community governance describes the roles, institutional forms and processes which local authorities will need to embrace if they are to meet the expectations of their citizens in a largely post-modern environment in which organisational roles are inherently fuzzy. Not surprisingly the concept has attracted academic and practitioner interest at the same time that there has been a growing recognition of the importance of the locality in policy-making.

This chapter has examined a sample of councils and the way in which they undertook their community outcomes process and made linkages with their LTCCP and other agencies. The research reflects a substantial degree of 
difference between councils, from those where compliance might be seen to be minimal or perfunctory, to others where councils saw the process as having real potential to improve the well-being of their citizens. The fact that local government approaches compliance with its legislation in a variety of ways is not a surprise and largely highlights the difficulties governments have when introducing new processes and practices.

Community planning is one of the mechanisms councils need to invest in if they are to achieve community governance and is identified in Chapter 3 as a component of the assessment model; some councils have recognised the potential for this. The research indicates that the LGA 2002 framework has the potential to stimulate long-term thinking and build effective collaboration around outcomes but there must be a political and managerial commitment. There must also be a commitment to participate in the process from other agencies.

Practice is at best somewhat patchy. 


\section{Chapter 6 Governance scenarios: testing opinion}

This chapter describes and analyses the responses received to a questionnaire that sought feedback on three alternative governance scenarios. It concludes with a discussion about whether or not any of the scenarios are better placed to achieve community governance than the others. It contributes to the discussion on size and structure in Chapter 7.

The question this chapter primarily addresses is whether the reform of local government in New Zealand has resulted in a system capable of delivering community governance and if so to what extent. To gather the necessary information a questionnaire was developed and a small number of experienced local government practitioners were invited to take part in the exercise, including discussion groups in which they were encouraged to elaborate on their answers. Participants were asked to comment on three different governance scenarios and answer a number of questions on each.

In order to seek a broad range of views on the strengths and weaknesses of different approaches to local governance, three stylised governance options were developed and written as future scenarios. These formed the basis of a questionnaire and subsequently three discussion groups which drew on a small number of invited practitioners that came from different parts of the local government sector, namely officials, elected members and policy advisers employed by LGNZ. The questionnaire sought to identify a range of views in order to identify the local government structures that are best suited to achieve community governance, and what needs to be done to achieve this. For example, are the most effective structures local, regional or integrated? Participants selected were individuals who were familiar with how local government worked and had a number of years' experience, either as elected members or working in or for the sector. The participants were not in any way a sample of local government opinion, their primary role was simply to highlight a range of issues to ensure that the assessment discussion considered as many issues and considerations as possible. The exercise was designed to add to the 
author's knowledge of factors influencing the effectiveness of different governance systems for achieving community governance.

Each participant was provided with the scenarios and a questionnaire; this was followed by three meetings with participants to discuss their answers, key points of which were recorded by the writer. In order to ensure opinions were based on a common understanding, participants were provided with a brief introduction to the theory of community governance, which they were asked to read before answering the questionnaire and participating in the discussions. The purpose of this research method was to examine how different approaches may contribute to community governance in a manner that is free from any current or topical policy issues. The three models were designed to mirror ideal types in order to enable discussion to occur about their relative strengths and weaknesses, from the perspective of enhancing community governance. Responses to the 'ideal' models or scenarios were then compared with New Zealand practice and conclusions drawn.

\section{The three scenarios}

The three scenarios described three broad governance approaches and were given neutral names to avoid typecasting by participants; these were Sparta (the localist option), Athens (the regional options) and Rome (the integrated option). The characteristics of each scenario are described in Table 19. 
Table 19 Stylised governance models

\begin{tabular}{|c|c|c|c|}
\hline & Localist & Regionalist & Integrated \\
\hline $\begin{array}{l}\text { General } \\
\text { characteristics }\end{array}$ & $\begin{array}{l}\text { Subsidiarity } \\
\text { principle - } \\
\text { undertakes all } \\
\text { functions except } \\
\text { those more } \\
\text { suited to higher } \\
\text { level } \\
\text { governments }\end{array}$ & $\begin{array}{l}\text { Regional } \\
\text { government as a } \\
\text { major provider of } \\
\text { services, devolved } \\
\text { from the centre and } \\
\text { transferred from } \\
\text { localities }\end{array}$ & $\begin{array}{l}\text { Little change in } \\
\text { responsibility for service } \\
\text { provision but much } \\
\text { greater alignment of } \\
\text { strategies and policies; } \\
\text { new statutory } \\
\text { mechanisms }\end{array}$ \\
\hline $\begin{array}{l}\text { Primary } \\
\text { rationale }\end{array}$ & $\begin{array}{l}\text { Proximity to } \\
\text { citizens }\end{array}$ & Greater capacity & $\begin{array}{l}\text { Equity/equality of } \\
\text { outcomes }\end{array}$ \\
\hline $\begin{array}{l}\text { Boundaries for } \\
\text { strategy } \\
\text { development }\end{array}$ & $\begin{array}{l}\text { Territorial and/or } \\
\text { regional council } \\
\text { boundaries }\end{array}$ & $\begin{array}{l}\text { Regional } \\
\text { boundaries, not } \\
\text { necessarily related } \\
\text { to status quo }\end{array}$ & $\begin{array}{l}\text { Not limited by local } \\
\text { authority or } \\
\text { departmental } \\
\text { boundaries; possible } \\
\text { alignment of government } \\
\text { department boundaries } \\
\text { with council boundaries }\end{array}$ \\
\hline $\begin{array}{l}\text { Opportunity for } \\
\text { 'joined-up' } \\
\text { approaches to } \\
\text { local } \\
\text { governance }\end{array}$ & $\begin{array}{l}\text { Poor, due to } \\
\text { variable } \\
\text { capacity and } \\
\text { boundary non- } \\
\text { alignment }\end{array}$ & $\begin{array}{l}\text { Generally good, but } \\
\text { depends on political } \\
\text { will }\end{array}$ & $\begin{array}{l}\text { Integration is a primary } \\
\text { focus; this model is } \\
\text { designed to encourage } \\
\text { and enable 'joined-up' } \\
\text { approaches }\end{array}$ \\
\hline Functions & $\begin{array}{l}\text { Devolution } \\
\text { medium to high }\end{array}$ & Devolution high & Devolution minimal \\
\hline $\begin{array}{l}\text { Current } \\
\text { alignment of } \\
\text { agency } \\
\text { jurisdictions }\end{array}$ & $\begin{array}{l}\text { Poor fit with } \\
\text { government } \\
\text { department/ } \\
\text { agency } \\
\text { jurisdictions }\end{array}$ & $\begin{array}{l}\text { Regional } \\
\text { boundaries close fit } \\
\text { with departmental } \\
\text { jurisdictions }\end{array}$ & $\begin{array}{l}\text { Need to overcome silo } \\
\text { approach of government } \\
\text { departments }\end{array}$ \\
\hline $\begin{array}{l}\text { Degree of } \\
\text { financial } \\
\text { autonomy }\end{array}$ & $\begin{array}{l}\text { Autonomy high } \\
\text { with a wide } \\
\text { range of funding } \\
\text { tools }\end{array}$ & $\begin{array}{l}\text { High level of } \\
\text { financial autonomy } \\
\text { with wide range of } \\
\text { funding tools }\end{array}$ & $\begin{array}{l}\text { Funding allocated by } \\
\text { agreements - use of } \\
\text { 'bulk funding' } \\
\text { arrangements - joint } \\
\text { contracting }\end{array}$ \\
\hline $\begin{array}{l}\text { The policy } \\
\text { realm or scope } \\
\text { to consider } \\
\text { strategic issues }\end{array}$ & $\begin{array}{l}\text { Authority/oppor- } \\
\text { tunity to } \\
\text { respond to or } \\
\text { address a wide } \\
\text { range of well- } \\
\text { being issues - } \\
\text { some national } \\
\text { policy } \\
\text { frameworks }\end{array}$ & $\begin{array}{l}\text { Authority/oppor- } \\
\text { tunity to respond to } \\
\text { or address a wide } \\
\text { range of well-being } \\
\text { issues - some } \\
\text { national policy } \\
\text { frameworks }\end{array}$ & $\begin{array}{l}\text { Constrained - local } \\
\text { responsiveness } \\
\text { influenced by negotiation } \\
\text { with centre }\end{array}$ \\
\hline
\end{tabular}


Each scenario takes a different approach to the location of decision-making. Localist approaches reflect the principle of subsidiarity and place decisionmaking at the lowest practical level of government. Regionalist approaches represent a mid-point, in which responsibilities are shifted up from local councils, for largely efficiency and fairness reasons, and shifted down from central government, for reasons primarily concerned with responsiveness. Integrated models work largely with the existing distribution of responsibilities and generally involve greater alignment of local, regional and central governments around common outcomes.

The strengths and weaknesses of each are well described in established theory (see Oates 1972, Bailey 1999, Cashin 1999). Localist models are seen as strong on responsiveness and opportunities for participation but score less well on issues of capacity and their ability to ensure equity; see, for example, the concept of the tyranny of the favoured quarter (Cashin 1999). Regional models provide better capacity and scope to deal with externalities and issues of fairness. In contrast to the others they scored poorly on opportunities for participation and responsiveness to local issues. Integrated systems attempt to achieve the benefits of national capacity with the information rich environment of the locality; however, they do so by compromising local autonomy.

The New Zealand approach to local government contains elements of all three, depending on the policy arena under consideration. For example, environmental management is strongly regional while water-related functions are strongly localist, with an apparent gradual move towards an integrated approach. Seen in overall terms the regional sphere in the New Zealand model is underdeveloped and has a potential to take a stronger integrated approach in some areas.

\section{Summary of responses}

Three discussion groups were held, with the membership of each group drawn from three distinct populations. One group was made up of elected members, a second group was drawn from council staff and a third group was made up of 
officials based in Wellington who specialised in aspects of local government policy - the average group size was six. Participants were identified in advance, invited to take part, and sent the scenarios with a request that the questionnaire be completed before taking part in the discussion groups. Elected members and officials were selected from participants attending a national local government conference. The policy advisers' group was selected from staff employed by Local Government New Zealand.

Discussion was led by the writer and focused on the reasons behind participants' questionnaire answers, the elaboration giving the writer an opportunity to seek clarification on various points. The purpose of the exercise was to provide a series of alternative perspectives on the strengths and weaknesses of three different options for strengthening community governance. Participants were not selected at random and the results have no statistical significance. The decision to segregate the participants by role was primarily to encourage participation (officials can feel constrained by working in the same groups as politicians and vice versa). It also gave an opportunity for any differences in views to be further interrogated; however, there was little divergence between the groups. A summary of the responses follows. 
Group 1: $\quad$ Elected members

A) Athens (Regional) Scenario

\begin{tabular}{|l|l|}
\hline \multicolumn{1}{|c|}{ Strengths } & \multicolumn{1}{|c|}{ Weaknesses } \\
Better incentives and resourcing for & Too much emphasis on national \\
staff & standards \\
Removes role duplication between & Referenda inconsistent with LTCCP \\
territorial and regional councils (one- & process \\
stop shop) & Health should remain a national \\
Single RMA agency & responsibility \\
More service cohesion & Elected members remote from the \\
Better funding for needy communities & community \\
Greater accountability & Less stability due to referenda \\
More uniformity of services and & Referenda undermines LGA 2002 \\
standards due to influence of national & planning process \\
policy statements & Decisions based on popularity rather \\
Represents a return to provincial & than long-term merit \\
government & Perception of double-dipping with \\
Devolution plus enhanced revenue- & larger revenue mix \\
raising & Diversity of knowledge based and \\
Mandatory community boards & increased workload for elected \\
members
\end{tabular}


B) Sparta (Local) Scenario

\begin{tabular}{|l|l|}
\hline \multicolumn{1}{|c|}{ Strengths } & \multicolumn{1}{|c|}{ Weaknesses } \\
\hline Improved networking between councils & Loss of monitoring role of regional \\
Economies of scale and expertise for & councils \\
core infrastructure & Community board parochialism \\
Improved representation and therefore & Community board role unclear \\
engagement & Equalisation funding formula needs to \\
Improved liaison between local and & include environmental characteristics \\
central government agencies & Indirect accountability \\
The most democratic and inclusive & De-amalgamation \\
option & \\
The voluntary nature of the regional & \\
arrangements & \\
Central government budgetary & \\
accountability for local outcomes & \\
\hline
\end{tabular}

C) Rome (Integrated) Scenario

\begin{tabular}{|l|l|}
\hline \multicolumn{1}{|c|}{ Strengths } & \multicolumn{1}{|c|}{ Weaknesses } \\
\hline Flexible and adaptive to changing & Reactive rather than proactive \\
circumstances & Boundaries may not suit all functions \\
Easier for government agencies to & Creates an additional layer of \\
relate to councils & bureaucracy preparing funding \\
Extra funding & applications \\
Fosters co-ordination rather than & Possible friction between central and \\
isolation & local government agencies due to \\
Government representation & perceptions of interference \\
recognises the role of local authorities & Risk of interference in local decision- \\
Opportunity for joint funding & making by national government \\
partnerships and integrated services & politicians \\
\hline
\end{tabular}




\begin{tabular}{|l|l|}
\hline Direct electoral accountability and & Little grass-roots involvement apart \\
boundary alignment for local and & from the formal opportunities \\
central agencies & Wishy-washy government interface \\
Ability to bid for funds & More central government bureaucracy \\
& at the local level \\
& Undermines local decision-making \\
& through government appointments and \\
& national plans \\
\hline
\end{tabular}

Participants were asked to rank the options for their ability to strengthen local governance. On a simple scale of three for the strongest and one for the lowest, participants had no clear preference - each option scored equal points.

Participants were also asked for their own thoughts on how community governance in New Zealand might be strengthened. The suggestions made by the elected members' groups were:

- strengthen regional councils' environmental watchdog role

- improve alignment between territorial boundaries and communities of interest

- establish an independent boundary commission

- provide more national standards with space for diversity

- increase remuneration for rural and provincial councillors to recognise workloads

- strengthen the role of elected members in environmental hearings made under the Resource Management Act. 
Group 2: $\quad$ Council staff

A) Athens (Regional) Scenario

\begin{tabular}{|l|l|}
\hline \multicolumn{1}{|c|}{ Strengths } & \multicolumn{1}{c|}{ Weaknesses } \\
\hline Local control & Political instability due to referenda \\
Economies of staff & Lack of consistency in service levels \\
Greater revenue options & between districts \\
One-stop shop & LTCCP would become \\
Opportunities for staff & unmanageable \\
Support for low socio-economic & Referenda would lead to apathy \\
communities & Too much emphasis on one-size-fits- \\
Devolution will result in less & all responses \\
duplication & Referenda would undermine large \\
& infrastructure investments \\
& Unitaries are 'judge and jury' \\
Community boards need defined role
\end{tabular}

B) Sparta (Local) Scenario

\begin{tabular}{|l|l|}
\hline \multicolumn{1}{|c|}{ Strengths } & \multicolumn{1}{|c|}{ Weaknesses } \\
\hline Regional organisations of councils & Community boards need stronger \\
Stronger commitment to community & delegations \\
outcomes & Risk of free-loading by councils \\
Additional tools to ensure government & Are community boards necessary? \\
programmes reflect local priorities & How about ward committees? \\
Collaboration and potential economies & Time taken to make decisions \\
of scale & Ambiguity about authority \\
Closer liaison between councils & Loss of regional accountability \\
Cost savings & Funding issues \\
Opportunities for staff & \\
Bigger voice when approaching the & \\
\hline
\end{tabular}


government

Greater involvement of local

communities

Equitable sharing of costs due to

economies of scale

Mandatory links with government departments

C) Rome (Integrated) Scenario

\begin{tabular}{|l|l|}
\hline \multicolumn{1}{|c|}{ Strengths } & \multicolumn{1}{|c|}{ Weaknesses } \\
Whole-of-community focus & Opportunity for government \\
Economy of scale & interference in local politics \\
Greater recognition by the government & Costly to implement \\
Sharing resources and staff & Potential for big councils to dominate \\
Opportunities for staff & LAAs \\
Access to funding & Bigger share taken by larger councils \\
Outcome-focused LAAs and pooled & Government appointees would lead to \\
funding & perceptions of central government \\
National plans as long as they are not & control \\
too prescriptive & \\
Ability to make adjustments as needed \\
instead of being imposed by 'white \\
collars' \\
Funding \\
Boundary alignment \\
Local Area Agreements (LAAs)
\end{tabular}

Participants were asked to rank the options for their ability to strengthen local governance. Using a simple scale of three for the strongest and one for the lowest, participants gave Sparta (localist) the highest ranking, followed by Athens (regional) with Rome (integrated) the lowest. Officials made the 
following suggestions about how community governance might be strengthened:

- Unitary councils should be promoted.

- Concern was expressed about direction of future change, especially any increase in functions.

- There was support for greater alignment around outcomes.

- The Rome option was seen to provide a better balance between national consistency and local diversity.

- Referenda enhances community prioritising, although citizens' juries might be better.

- Territorial authorities provide better opportunities for citizen participation than regional councils.

- Community boards, because of their proximity, provide the best opportunity for participation.

Group 3: National local government policy advisers
A) Athens (Regional) Scenario

\begin{tabular}{|l|l|}
\hline \multicolumn{1}{|c|}{ Strengths } & \multicolumn{1}{c|}{ Weaknesses } \\
\hline Equalisation ensures adequate & National Policy Statements can \\
funding for low socio-economic & undermine local autonomy \\
councils & Greater complexity and risk of \\
Extra taxes to reflect wider & overlaps \\
responsibilities & Extra accountability leads to greater \\
Consolidation of regional and & risk aversion: difficult to create \\
territorial councils & change \\
Referenda may increase public & Citizens may be unwilling to \\
confidence & participate in referenda \\
Referenda strengthens citizens' voice & How willing are citizens to participate \\
between election & in referenda? \\
\hline
\end{tabular}




\begin{tabular}{|c|c|}
\hline $\begin{array}{l}\text { Potential economies of scale } \\
\text { Funding for poor communities } \\
\text { Ability to provide locally appropriate } \\
\text { services } \\
\text { Better funding } \\
\text { Community input into all decisions } \\
\text { Councils are more accountable to } \\
\text { communities through the popular vote }\end{array}$ & $\begin{array}{l}\text { Is there capacity to take on additional } \\
\text { responsibilities? } \\
\text { Loss of local autonomy due to } \\
\text { national policy statements (NPS) } \\
\text { Local opposition to new taxes } \\
\text { Referenda may undermine } \\
\text { governance } \\
\text { Less access to elected members } \\
\text { Potential for local services to be } \\
\text { provided at different quality levels } \\
\text { Potentially undermines focus on the } \\
\text { environment } \\
\text { No flexibility } \\
\text { Does not allow for local diversity } \\
\text { within NPS } \\
\text { Risk of reinventing the wheel on a } \\
\text { regular basis } \\
\text { Equalisation difficult due to the } \\
\text { different circumstances of } \\
\text { communities } \\
\text { cotential to undermine the national } \\
\text { Government might curtail minority } \\
\text { interests during periods of austerity }\end{array}$ \\
\hline
\end{tabular}

B) Sparta (Local) Scenario

\begin{tabular}{|l|l|}
\hline \multicolumn{1}{|c|}{ Strengths } & \multicolumn{1}{c|}{ Weaknesses } \\
\hline Joined-up thinking & Blurs separation between regional and \\
Ability to balance national and local & territorial councils for RMA \\
priorities & responsibilities \\
Government departments taking local & Consultation requirements \\
\hline
\end{tabular}




\begin{tabular}{|l|l|}
\hline and regional outcomes into account & bureaucratic and subject to interest \\
Equalisation grants & group capture \\
Strong access to elected members & Risks of local power struggles \\
Community voice through community & The problem of consolidating local and \\
boards & regional outcomes \\
More local autonomy & Greater administrative costs to \\
Shared services & maintain the structure \\
Ability to influence central government & Lack of any economy of scale \\
plans & Inconsistent service levels between \\
Providing co-operation between & councils \\
councils & No practical mechanisms by which \\
Consolidation of regional and territorial & government departments can give \\
councils & effect to outcomes \\
& Is the compulsory minimum size \\
& necessary? \\
& Costs of a greater number of councils \\
&
\end{tabular}

C) Rome (Integrated) Scenario

\begin{tabular}{|l|l|}
\hline \multicolumn{1}{|c|}{ Strengths } & \multicolumn{1}{c|}{ Weaknesses } \\
National outcomes easier to establish & Loss of local diversity \\
and deliver & Boundary alignment difficult \\
Better for addressing complex issues & Risks of bureaucratic capture \\
Alignment of local and central & Unclear what role the government \\
boundaries & appointee will play \\
LAAs & Councils have different capacity to \\
Ability to make budget bids alongside & engage with and influence central \\
departments & government \\
Joint funding, planning and alignment & Could take a long time to establish \\
Ability to influence central government & Might discriminate against small \\
plans & projects \\
More central government presence in & Diminished community engagement \\
\hline
\end{tabular}




\begin{tabular}{|l|l|}
\hline the regions & advantaging formal groups \\
Better and easier monitoring due to & \\
aligned boundaries & \\
National plan aligned with community & \\
outcomes & \\
Move away from ad hoc policy-making & \\
Ability to fund community projects & \\
Alignment & \\
\hline
\end{tabular}

Participants were asked to rank the options for their ability to strengthen local governance. Using a simple scale of three for the strongest and one for the lowest, participants had no clear preference. All three options received the same number of points. In order to strengthen community governance, the local government policy advisers highlighted the need to:

- clarify national and local values

- understand what functions are important to community governance

- jointly plan and set budgets between central and local government

- identify new ways to promote participation, such as increasing voter turnout

- obtain more funding for 'core' functions

- get government departments to reflect local outcomes in their business plans

- achieve greater co-ordination in local funding and programmes

- give local government a greater say in legislation and policy formation

- provide councils with additional funding tools such as greater fee-setting ability

- spend more time developing community understanding of issues

- ensure councils have clearer community priorities based on a thorough understanding of the issues. 


\section{Analysis}

The discussion groups' comments provided a mix of views about the right institutional mix for strengthening community governance. A number of participants saw larger authorities, for example, the unitary model, as providing better economies of scale, opportunities for professional advancement by staff and an ability to provide more equitable outcomes. However, concerns were raised about complexity and the risk of overlap with higher level governments with the consequential reduction in citizen influence (voice). A different set of concerns was raised in relation to the Rome scenario. This scenario represented a more integrated and joined-up model of local governance (integrated with central government) but caused some participants to express concerns about loss of diversity and risk of bureaucratic capture, again caused by citizen access difficulties.

All group participants tended to highlight the importance of the 'local' in local government, regarded representation as a strong value and were suspicious of national solutions imposed by central government The localist (Sparta) scenario was seen as the most democratic and inclusive option; however, some concern was expressed at the lack of an effective regional level of government, lack of economies of scale and potential difficulties in aligning local and regional outcomes with this option. The localist scenario was also seen to be more susceptible to interest group capture than the other options. Athens, the regional scenario, was valued for its ability to give local government officials greater opportunity to specialise, reduce duplication between territorial and regional councils and increase devolution (greater capacity allows greater devolution). It was also seen to have stronger funding sources and greater ability to deal with socio-economic differences within communities, allowing it to address distributional issues and reduce tax exporting. Reservations expressed about this scenario concerned its lack of flexibility, a reduction in environmental focus (existing regional councils are primarily environmental watchdogs) and the potential to overlook minority interests. In relation to the third scenario, 
Rome (the integrated option), support was expressed for its ability to undertake integrated planning, align boundaries with government departments and agencies and share resources. There were, however, a number of reservations expressed about this option, such as the potential for increased central government interference, bureaucratic capture and loss of local diversity.

Following the discussion of the relative strengths and weaknesses of the scenarios participants were then asked to suggest options for strengthening local governance. The results were quite varied with no obvious correlation with occupation group and appeared to be heavily influenced by issues that were current in the local government environment. The most commonly identified themes were:

- integration and alignment with central government: replies under this heading ranged from more national standards (with room for diversity) to joint planning and budgeting with central government agencies, as well as the suggestion that departments should be required to show how they were contributing to community outcomes

- greater citizen participation: all groups suggested that opportunities for citizens to participate in councils' decision-making processes should be enhanced. Ideas ranged from promoting the use of community boards (better for community engagement due to their proximity to citizens) to efforts to increase voter turnout and civics education

- building capacity: a number of participants highlighted the need to address capacity issues, including strengthening environmental regulatory roles, strengthening the role of elected members (and their remuneration) and increasing funding for councils to perform their 'core' roles.

\section{Conclusion}

In summary, participants valued local government approaches which had high levels of local autonomy and provided opportunities to enable citizens to have a meaningful impact on decisions that affect them. This approach, which tends 
towards the localist scenario, was qualified in two important ways. The first was a concern with capacity, and a belief that some activities needed to be undertaken on a larger scale to achieve both economies of scale and the appropriate degree of expertise. The second was a desire to see a better alignment of local and national policies, although not at the expense of autonomy. Strong community governance was regarded as finding a balance between the ability to respond to local circumstances and ensuring an element of policy consistency through some form of national framework, echoing the notion of 'managed difference' (see Lyons 2007). Seen in the context of the current New Zealand approach to local government, which contains elements of each scenario, the following observations can be made:

- Policies to strengthen local autonomy, such as the introduction of general empowerment, should be supported.

- A greater focus is required on mechanisms for integrated planning and policy-making.

- Both local and central government need to support programmes to enhance civic literacy.

- Capacity in New Zealand local government is an issue and consideration should be given to some form of equalisation funding to assist implementation by smaller councils.

The outcomes of this research method reinforce a number of the conclusions drawn from the case studies of councils undertaking community planning, in particular the diverse capacity of the sector and ambiguity about the potential for greater integration with central government and its agencies. However, there was no consensus among the participants about the optimal structures for achieving community governance. Feedback from participants tended to focus on what might be described as 'conventional' local government issues, such as relationships between territorial and regional councils, adequacy of funding, and consolidation. Few participants were able to divorce their thinking from immediate issues to focus on what was, for them, a largely theoretical conception of local government. While many useful observations were made to 
address current 'problems' in terms of the overall objective, identifying options for strengthening community governance, no single scenario was supported. 


\section{Chapter 7 The assessment model}

This chapter applies the assessment model developed in Chapter 3. It analyses each of the dimensions identified in the model with reference to specific measures. In relation to the ability of the New Zealand system to achieve a community governance approach the dimensions are assessed as being either adequate or showing room for improvement.

Previous chapters have noted the changing socio-political environment in which local governments operate and the rise of complex problems that cross intersectoral boundaries. Changing circumstances have forced councils to look at new ways of operating in order not only to improve local outcomes but to remain relevant to their citizens. Addressing outcomes inevitably involves tackling issues that sit outside the realm of traditional local government concerns and underpins calls for a more conscious endorsement of community governance. Community governance, as the term is used in this thesis, is a particular concept of local government which places councils at the centre of a network of local, regional and national agencies and organisations. Councils that take a community governance approach are concerned with the full range of issues confronting the communities within their jurisdictions, best exemplified in the notion of place-shaping (Lyons 2007).

The community governance assessment model was developed in Chapter 3 and has been designed to assess the degree to which the New Zealand system is able to adopt a community governance approach. The 10 dimensions outlined in Chapter 3 form the structure of this chapter, and an assessment as to whether it is 'adequate' or has 'room for improvement' is given for each.

\section{Size and structure}

There are two measures for this dimension: council populations (size) and the degree of multi-level governance (structure). Size has been selected as a proxy for capacity and attempts to answer the question whether the population size 
served by councils in New Zealand is likely to affect their ability to deliver community governance. Are councils so small, for example, that they are unable to both employ appropriately skilled staff and establish effective decision-making systems? Structure concerns the ability of the local government system to undertake activities which have different fields of benefit, as this will affect the ability of higher order governments to devolve.

\section{Average population}

The size and structure dimension is concerned with the types of local authorities within a given system and their relative scale. It is proposed that the number of citizens a council represents provides a useful proxy for thinking about its capability and capacity. For example, the number of citizens has a direct effect on council income and tends to have a concomitant effect on the competency of staff and organisational systems.

Within any given system, the size of local authorities is the outcome of an ongoing tension between efficiency and responsiveness. Efficiency arguments are generally defined as achieving economies of scale, while responsiveness arguments are described as protecting democracy and holding decision-makers to account. Ultimately whether councils are large or small depends on the tradeoff between these contrasting principles. Figure 9 examines the number of councils by population. 
Figure 9 Number of councils by population

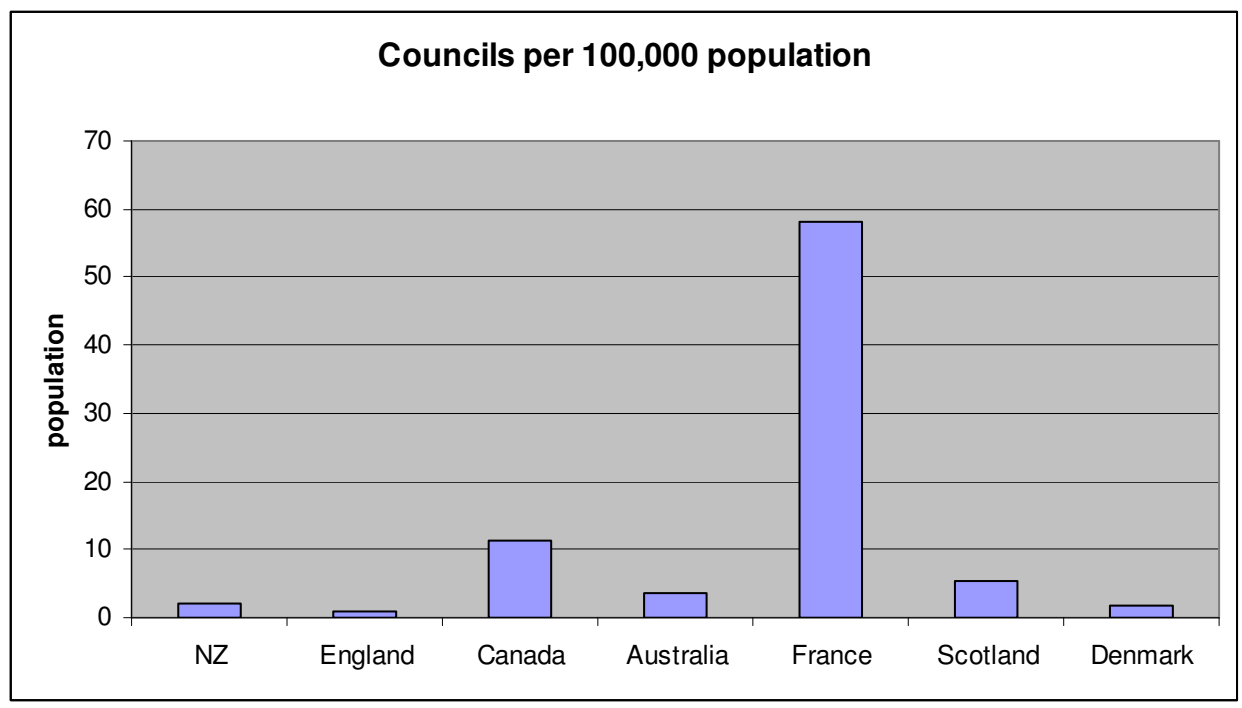

(Source: data drawn from Norton 1994 and local government association websites)

As Figure 9 indicates, the number of councils in New Zealand in proportion to the country's population sits towards the bottom of the scale, with a ratio similar to Denmark and below that of its peers, like Canada and Australia. Despite such evidence, however, the conventional wisdom underpinning local government reform has been the assumption that there are too many local authorities and that they should be larger. Since 1989, for example, the law in New Zealand has required that any new territorial authorities must have a population in excess of 10,000 permanent residents (see LGA 2002) - a figure which, while large in comparison with the size of councils in the United States, is small in comparison with the United Kingdom.

Twenty years after the consolidation of local authorities in New Zealand the consolidation narrative has lost none of its appeal, for example, in the 2005 general election at least three parties promoted local government policies calling for a radical reduction in the number of territorial authorities (see McKinlay 2006). The average population of territorial local authorities in New Zealand is, however, relatively large. Table 20 indicates the average populations of local authorities in a range of countries. While the size of New Zealand councils is at the larger end of the scale, the figure fails to indicate the spread of sizes. New Zealand has a significant number of small local authorities 
with population levels under 20,000 (approximately 30 per cent), reflecting the 'stretched-out' topography of the country and the number of large but sparsely populated districts, compared with compact and intensely settled Europe.

Table $20 \quad$ Average council size by country ${ }^{67}$

\begin{tabular}{|l|l|}
\hline \multicolumn{1}{|c|}{ Country } & \multicolumn{1}{|c|}{$\begin{array}{c}\text { Average population per } \\
\text { local authority }\end{array}$} \\
\hline New Zealand & 54,750 \\
Republic of Ireland & 33,000 \\
United Kingdom & 118,440 \\
France & 1,580 \\
Switzerland & 2,210 \\
Scotland & 153,000 \\
Australia & 40,000 \\
Denmark & 18,760 \\
Norway & 9,000 \\
Netherlands & 23,000 \\
Northern Ireland & 64,980 \\
\hline
\end{tabular}

(Source: Norton 1994 and local government association websites)

The first phase of local government reform was driven by concerns that the sector was fragmented and capacity was uneven (see Chapter 1). For example, one of the overriding principles used by the Local Government Commission at the time was to make the boundaries of the new authorities as coterminous as possible with communities of interest (see McKinlay 1996). While this was arguably achieved in a number of communities, for example Christchurch where the council's administrative boundaries matched the city's urban form, it also resulted in a significant number of councils with small populations (see Appendix 1). The relatively long tail of small councils has raised issues about their financial sustainability with some commentators, including respondents to

\footnotetext{
${ }^{67}$ Source: Australian Local Government Association www.alga.asn.au; Knox (2002) Review of Public Administration: Unpublished Information Briefing Paper, School of policy Studies, University of Ulster; Norton (1994).
} 
the scenario questionnaire (see Chapter 6), raising questions about their capacity to continue to fund essential infrastructure (see McKinlay 2006). ${ }^{68}$ Despite such criticism, and the existence of resource constraints in relation to some infrastructural issues, such as the quality of small community water schemes, a community governance approach should assist smaller authorities to mobilise community support and achieve good community outcomes. It is not clear that size alone should be the major inhibitor - particularly if an effective multi-level governance structure is established.

\section{Multi-level governance arrangements}

The second measure for this dimension is the degree of multi-level governance in the New Zealand system. Multi-level governance arrangements tend to allow governments to establish a fit between area of benefit and 'who pays'. Writers such as Bailey (1999) argue for a correspondence between jurisdictional boundaries and areas of benefit created by the services local authorities provide. This, however, is a complex task as different functions have different areas of benefit, weakening the correspondence argument. There are three approaches to dealing with the problem of multiple functions with varying areas of benefit. One approach, fragmentation, guided the Thatcher government's local government reform strategy and ultimately gave rise to community governance theory in the first place (see Rhodes 2007). A second approach is to create authorities with large populations that also cover large geographical areas in order to attempt to incorporate the area of benefit of each activity. Problems with this approach are the externalities and tax transfers that occur where activity boundaries fail to align with administrative boundaries and most importantly a diminution of democratic representation. ${ }^{69}$ The third approach for dealing with the correspondence issue is to develop multi-level forms of governance, regions or counties, able to take responsibility for those subnational activities that benefit more than a single jurisdiction.

\footnotetext{
${ }^{68}$ An example of what small councils facing large infrastructure costs have done was Banks Peninsula District Council, which triggered a review that led ultimately to it being absorbed into its larger neighbour, Christchurch City Council, in 2006.

${ }^{69}$ A concern that English councils were too big and unresponsive has been a driving influence on the Conservative Party's local government policy (see Cameron 2009).
} 
The ability to achieve this alignment in New Zealand has been diminished by the emphasis on separating regulatory and operational functions which guided the institutional restructuring of local government in 1988/89. Aligning territorial and regional council planning and activity in order to address community issues is made more complex because of the role regional councils play, predominantly a type of environmental watchdog (although a number have broader service delivery roles, for example Greater Wellington). Regions that have taken this to be their dominant responsibility have sometimes found themselves in conflict with territorial authorities where, for example, a local development might not proceed because it has failed to meet prescribed regional standards.

The nature of the New Zealand local government structure, with its two forms of directly elected local authorities with separate functions in a horizontal relationship, is relatively unique. Previous reform objectives, which were largely about enhancing accountability and transparency (ensuring a separation between 'poacher and gamekeeper'), have resulted in a relatively inflexible structure. The more common approach to designing local government systems, so that those who benefit from services are also the same population that pays for them, involves creating either large local authorities, such as in the United Kingdom, or some form of multi-tiered structure (see Table 21). 
Table $21 \quad$ Local government structures

\begin{tabular}{|c|c|c|c|}
\hline Country & $\begin{array}{l}\text { Population } \\
\text { (m) }\end{array}$ & $\begin{array}{l}\text { Sub-national } \\
\text { tier }\end{array}$ & Local tier(s) \\
\hline Denmark & 5.5 & 5 regions & 98 municipalities \\
\hline France & 60.9 & & $\begin{array}{l}22 \text { regions } \\
96 \text { departments } \\
35,000 \text { communes }\end{array}$ \\
\hline Germany & 82.4 & 16 Lander & $\begin{array}{l}323 \text { counties } \\
117 \text { unitary cities } \\
13,299 \text { municipalities }\end{array}$ \\
\hline Netherlands & 16.6 & 12 provinces & 443 municipalities \\
\hline Australia & 20.4 & $\begin{array}{l}6 \text { states } \\
3 \text { territories }\end{array}$ & 565 local councils \\
\hline Canada & 33.4 & $\begin{array}{l}10 \text { provinces } \\
3 \text { territories }\end{array}$ & $\begin{array}{l}2 \text { metropolitan } \\
\text { communities } \\
143 \text { upper/regional } \\
\text { councils } \\
3,647 \text { local councils }\end{array}$ \\
\hline South Africa & 47.4 & 9 provinces & $\begin{array}{l}6 \text { metropolitan councils } \\
46 \text { districts } \\
321 \text { municipalities }\end{array}$ \\
\hline New Zealand & 4.5 & $\begin{array}{l}12 \text { regional } \\
\text { councils }\end{array}$ & 73 territorial authorities \\
\hline England & 50.4 & $\begin{array}{l}\text { Greater London } \\
\text { Authority } \\
8 \text { regions } \\
\text { (administrative) }\end{array}$ & $\begin{array}{l}34 \text { counties councils } \\
238 \text { district councils } \\
36 \text { metropolitan councils } \\
\text { (unitary) } \\
47 \text { unitary councils } \\
33 \text { London boroughs }\end{array}$ \\
\hline
\end{tabular}

(Source: adapted from Gough 2009, p. 7) 
Local government systems in the developed world tend to be multi-level and better reflect the different nature and circumstances of communities than single tier systems (see Norton 1994). Large urban conglomerations can be either unitary metropolitan councils or operate within some sort of metropolitan authority that undertakes issues of metropolitan scale. Such arrangements can also enhance the capacity of local government systems to take on a greater number of functions, for example, the Danish approach. Following reform in 2007 Denmark 'downsized' to five regions, which were given responsibility for providing major public services, such as hospitals and secondary schools (see www.kl.dk/English/Local-Government-Reform). In the Australian context this is partly achieved by the state governments playing some of the roles carried out by counties or regions in Europe and the Americas, for example, the provision of health services.

Since the late eighties, local government reform in New Zealand has appeared to place strong emphasis on structural consistency throughout the country, with initially only one council, Gisborne District, standing out from the national model by being given both territorial and regional council powers. Regional councils, because they were established with a limited mandate, were poorly placed to take on additional responsibilities, even if such responsibilities were promoted by government departments (for example, regional development initiatives and transport funding). In addition, the boundaries of regional councils are based on river catchments, which have, in most cases, a poor correlation with communities of interest, further reducing their suitability as providers of a broader range of services. A number of Australian local authorities address this issue of providing regional services to regional communities, through what are known as regional organisations of councils (ROCs). These are voluntary associations of local authorities established for the purpose of delivering shared services or those services which are more efficiently provided across council boundaries. Although ROCs are informal structures, they can have a high degree of permanence. For example, the 12 councils of the Hunter Valley have established a legal entity called Hunter Councils Incorporated to undertake a range of joined-up programmes. The Hunter ROC has been in existence for 50 years and provides opportunities for sharing professional expertise, regional 
procurement and inter-council collaborations. ${ }^{70}$ ROCs, which are basically a form of networked councils, have the potential to more strongly match placebased communities than the regional council model in New Zealand; however, many ROCs are short lived and may be subject to political expediency. The complexity of designing structures which allow for capacity and efficiency, as well as democracy, was highlighted in the replies given to the scenario questionnaire (see Chapter 6). Respondents' replies were tempered by concerns that in any reorganisation 'localness' should not be lost, autonomy must be preserved and participation guaranteed. In other words, there was a need to find a balance.

\section{Dimension assessment}

In relation to this dimension, size and structure, New Zealand's councils are relatively large by international standards, and, following the first stage of local government reform, there is an improved fit between administrative boundaries and communities of interest. Both factors suggest that, in terms of achieving community governance, size and structure are not major obstacles; however, the limited role of regional councils has proven to be a major inhibitor to significant devolution, and devolution is directly related to influencing outcomes.

Although the LGA 2002 provided regional councils with a power of general competence and detailed a process by which territorial authority functions could be clustered and transferred to regional councils, only one authority, Greater Wellington, has exploited the opportunity. New Zealand's local government structure is currently poorly placed to deal with both overlapping issues and non-environmental issues with a regional area of benefit.

Because of these limitations this indicator is assessed as having room for improvement.

\footnotetext{
${ }^{70}$ See the Hunter Councils' website at www.huntercouncils.com.au.
} 


\section{Finance}

This dimension is concerned with councils' financial autonomy and the degree to which the local authority has freedom to make expenditure decisions in order to respond to local concerns and influence outcomes. The measure for this dimension concerns the proportion of 'own source' revenue raised by the local government system.

Local government theory argues that local authorities should be largely selffunding for reasons of both accountability and efficiency (Bailey 1999). In addition access to, and control over, funding is directly related to the capacity of councils to influence local outcomes. The issue of budgetary discretion is thus highlighted, a fundamental principle also recognised by the Committee of Ministers of the Council of Europe (2000), which resolved that member states should ensure a fair distribution of public financial resources between the different tiers of government, taking account of the responsibilities assigned to each of the tiers and their evolution. It recommends that local authorities have a system of financing their expenditure which is based on the following principles:

- Local authorities' resources and their allocation must be consistent with the need to carry out their responsibilities effectively.

- A substantial proportion of transfers, as well as their own resources, must not be earmarked.

- Local authorities are entitled, within the national economic policy, to raise adequate resources of their own; the possibility of sound competition in tax levels should be maintained, while avoiding harmful tax competition.

- The amount of state grants must be fair and foreseeable.

- The system of financing as a whole must be consistent with the constraints of the national economic policy (Committee of Ministers 2000, accessed on 6 April 2009 at www.coe.int). 
In relation to the finance dimension, international practice and theory suggest that councils should be empowered to allocate financial resources, their own as well as transfers, according to their responsibilities and in accordance with consistent rules. In addressing this, Bailey (1999) proposes two key principles. The first is that councils should have access to buoyant local taxes which, along with user charges, enable them to be largely self-financing. The second is that central government transfers should primarily be concerned with resolving spillovers and financial inequities (councils with low finance-raising potential). This dimension uses a single measure, the level of financial autonomy exercised by local authorities.

In order to establish programmes to meet local priorities, local governments require a funding base that not only maximises their autonomy but also provides them with the ability to set local tax levels or have access to untied national grants. It is an issue that has caused considerable local, national and international debate and, as Table 22 indicates, few countries achieve the ideal outlined by Bailey and the Council of Europe. In Ireland, for example, the right to levy local taxes on property was removed by the state in the 1970 s and has never been reinstated, despite repeated calls from the local government sector and public inquiries.

Table 22 Intergovernmental transfers

\begin{tabular}{|l|l|l|}
\hline Country & $\begin{array}{l}\text { Intergovernmental transfers - } \\
\text { general (as percentage of total } \\
\text { municipal resources) }\end{array}$ & $\begin{array}{l}\text { Intergovernmental transfers - } \\
\text { tied (as percentage of total } \\
\text { municipal resources) }\end{array}$ \\
\hline Denmark & 12 & 0 \\
Finland & 28 & 1 \\
Ireland & 11 & 46 \\
Norway & 17 & 14 \\
Sweden & 11 & 8 \\
UK & 32 & 27 \\
NZ & 0 & 12 \\
\hline
\end{tabular}

(Source: adapted from Bailey, 1999, p.239) 
The New Zealand model of local government finance is unique for the comparatively high proportion of income received from property taxes (rates) and charges and the low proportion of central government transfers (see Dollery 2008). As illustrated in Table 23, income from property taxes and charges makes up 57 per cent of total income - there is no limit on the rate of tax that can be charged and there is no rate-capping regime. Councils have the authority to set property tax rates after public consultation and the adoption of their annual plan and budget. The relatively small proportion of funding which comes from central government is primarily local government's share of the road tax and is targeted so that councils in lower socio-economic areas receive some advantage. Since the formation of the Labour-led Government in 1999 funds have been made available to help communities upgrade sewerage and water treatment schemes. Smaller funds have also been established that contribute to local government-owned infrastructure that services the tourism industry as well as assisting with the implementation of new regulatory regimes. Despite requests from the local government sector itself for more generalised forms of funding assistance, central government continues to favour needsbased approaches.

Table 23 Local government income sources

\begin{tabular}{|l|l|}
\hline & NZ \\
\hline $\begin{array}{l}\text { Property taxes and } \\
\text { charges }\end{array}$ & $56.1 \%$ \\
\hline Regulatory income & $5.2 \%$ \\
\hline $\begin{array}{l}\text { Central government } \\
\text { grants }\end{array}$ & $12.7 \%$ \\
\hline Investment income & $5.7 \%$ \\
\hline Sales and charges & $20.2 \%$ \\
\hline
\end{tabular}

(Source: www.localcouncils.govt.nz) 
While councils have political autonomy in setting annual levels of property taxes, the growth in council tax demands has become a major political issue with affordability problems for a range of citizen groups, particularly those on fixed incomes. Pressure has been exacerbated by the fact that certain types of properties have increased in value at a much faster rate than the average. For example, coastal properties have been subject to large shifts in value and property taxes, despite efforts by councils to ameliorate the impact of valuations by using uniform charges and differentials. Many retired people live in these areas and consequently are more affected by increased rates.

A government-appointed Commission of Inquiry concluded that the proportion of property rates, at 57 per cent of council income, should be reduced to about 50 per cent (New Zealand Government 2007). The Inquiry's suggestion for achieving this was that water and wastewater services be funded by a form of volumetric charging, that councils should reduce the level of depreciation which is currently funded, and that additional central government transfers should be provided. The Inquiry also recommended that council discretion to set differentials on the general rate and use uniform annual general charges should be replaced with targeted rates in the interest of transparency. ${ }^{71}$ At the time of writing, the Government was considering the implications of the Inquiry's recommendations.

The extent of New Zealand local government's reliance on a local property tax poses something of an interesting case. The advantages of local property taxes from an economic perspective are that they are highly visible, promote local autonomy and can be increased to meet the costs of local public services. Yet there are political constraints on councils which make it difficult for elected members to increase rates faster than the willingness of citizens to pay and it was notable that a large number of candidates successfully stood on anti-rateincrease platforms in the 2007 local government elections. The degree of political change in those councils highlights the difficulty of increasing property

\footnotetext{
${ }^{71}$ It is common practice for councils to use a minus differential to reduce the rates on rural properties as a way of acknowledging lower use of council services. Likewise many councils have positive differential on businesses to reflect the additional costs of servicing central business districts.
} 
taxes beyond what citizens are prepared to pay while at the same time highlighting the question of whether or not councils have access to the appropriate funding tools to provide the necessary public amenities modern cities require. Despite the technical advantages of property taxes, the reliance on a single form of tax potentially limits the behaviours of local authorities, particularly since the introduction of long-term financial management practices in 1996, which heavily emphasise prudent financial management of assets.

While some additional funding tools have been provided to reduce reliance on property taxes, most importantly the power to charge levies on new developments to pay for increased demands on existing infrastructure (development contributions), the reliance on property taxes as councils' major source of income creates strong disincentives to allocate resources in a nonconservative manner. The recent success of electoral coalitions standing against increases in property taxes has reinforced the notion that councils should stick to core business, usually defined as the operation of network infrastructure rather than any proactive focus to achieve outcomes. The pressure on local government politicians not to raise property tax rates beyond a minimum threshold (usually the rate of the consumer price index) often comes from ministers of local government, and business and farming groups, as well as citizens, and is a dominant concern for councils at annual planning time.

\section{Dimension assessment}

While local government's strong financial autonomy is an important positive in relation to its capacity to exercise community governance, there is at least one limiting factor, the sector's reliance on a single tax base. This has a poor correlation with ability to pay and discourages councils from undertaking activities that might have fiscal consequences. However, given the level of autonomy possessed by councils and the fact that the approach to community governance taken by this thesis is primarily about working more effectively with other agencies and communities rather than expanding the range of services undertaken by councils (enabling and facilitating), this dimension is assessed as adequate. 


\section{Empowerment}

This dimension is concerned with the manner in which local authorities are empowered and is designed to assess councils' freedom, or flexibility, to respond to local concerns. Two measures are used, the adequacy of the accountability regime and the adequacy of the empowerment regime.

The adequacy of the accountability regime

Community governance theory promotes an idea of local government as a largely autonomous form of local polity which enables citizens to make meaningful choices about matters of collective interest and decide "collectively binding rules and policies ... a means of reconciling and revealing preferences" (Andrew and Goldsmith 1998, p. 115). The degree to which local government systems allow for meaningful dialogue partly depends on the level of freedom local decision-makers have to set agendas and consider matters raised by their citizens, which in turn depends on the way in which accountability and powers are defined.

Local government accountability regimes tend to be of three types: top-down, bottom-up and rules based (see Table 24). Categories (B) and (C) are generally regarded as the most conducive to a community governance orientation.

Table 24 Accountability regimes

\begin{tabular}{|l|l|l|}
\hline & Characteristics & Instruments \\
\hline A) Top down & $\begin{array}{l}\text { Higher level governments set } \\
\text { directions and monitor } \\
\text { performance e.g. local government } \\
\text { as decentralised service providers }\end{array}$ & $\begin{array}{l}\text { Ministerial directives } \\
\text { Performance } \\
\text { agreements }\end{array}$ \\
\hline B) Bottom up & $\begin{array}{l}\text { Voters and citizens } \\
\text { Framework to ensure integrity of } \\
\text { representation }\end{array}$ & $\begin{array}{l}\text { Binding referenda } \\
\text { Proportional } \\
\text { representation } \\
\end{array}$ \\
& & $\begin{array}{l}\text { Mandatory consultation } \\
\text { Transparency }\end{array}$ \\
\hline
\end{tabular}




\begin{tabular}{|l|l|l|}
\hline & & Compulsory voting \\
\hline C) Rules based & Administrative law principles & Judicial review \\
& Prescribed decision-making & Scrutiny by \\
& criteria & parliamentary agencies \\
& & (independent) \\
\hline
\end{tabular}

Recognising that in unitary regimes ultimate authority sits with parliament or, in federal states, the constitution, top-down accountability places considerable authority in the hands of higher level governments, enabling them to intervene directly in the affairs of councils. Intervention might be exercised through the right to appoint members of councils, as in France, or allow a minister to overrule a council decision because it conflicted with government policy. Such accountability regimes are likely to be associated with high levels of government transfers, where councils are decentralised service providers with minimal autonomy to set local priorities. In contrast, bottom-up regimes place emphasis on giving citizens the mechanisms for holding their elected representatives to account. These can include binding referenda, such as those used in Switzerland and some American states; proportional voting systems, which are better at ensuring the electoral make-up of councils reflects community choices; mandatory consultation provisions through the use of participatory democracy, such as participatory budgeting approaches in Brazil; and the creation of smaller local authorities to encourage the Tiebout effect. Another approach to strengthening accountability is by ensuring compliance with agreed decisionmaking processes. Under this approach any outcome (as long as it is within the law) is mandated if councils observed correct process in arriving at their decision. Ensuring processes are complied with is normally the responsibility of the courts and third party agencies like the Ombudsman's Office and the Auditor-General, or their equivalents.

While Table 24 treats the three styles as discrete, in practice accountability regimes tend to have elements of all three approaches. In New Zealand the emphasis has largely been on categories (B) and (C), involving citizen oversight through mandatory consultation requirements and strengthening the role of third 
party oversight, particularly through the Auditor-General's and Ombudsman's offices.

The adequacy of the empowerment regime

The nature of a local government system's powers can similarly be written in a broad or narrow sense. Three broad approaches exist: powers defined by constitution, general empowerment or ultra vires (see Table 25).

Table $25 \quad$ Empowerment models

\begin{tabular}{|l|l|l|}
\hline A & $\begin{array}{l}\text { Recognition of local government in } \\
\text { the nation's constitution }\end{array}$ & South Africa \\
\hline B & $\begin{array}{l}\text { The provision of general } \\
\text { empowerment provisions in local } \\
\text { government's empowering statute }\end{array}$ & New Zealand, Australia \\
\hline C & $\begin{array}{l}\text { An empowering statute that limits } \\
\text { council activity to prescribed roles } \\
\text { and process i.e. the ultra vires } \\
\text { principle }\end{array}$ & Fiji, United Kingdom (New \\
Zealand pre-LGA 2002)
\end{tabular}

In practice, approaches may feature a combination of elements. While officials debated the nature of the general empowerment clause to be incorporated in the LGA 2002, some of the participants raised concerns that it should be drafted in a manner which discouraged the judiciary from 'second guessing' parliament's intentions. The United Kingdom, for example, has a power of wellbeing which is similar to general empowerment but is in fact limited by the existence of a range of other more specific powers related to individual functions. General empowerment can also be limited by the use of specific proscriptions, such as provisions that make it ultra vires for a council to undertake national functions, like policing or defence. A number of cities in the United States have established 'home rule' charters which are in most respects similar to the general empowering provisions found in New Zealand and much of the OECD. 
The LGA 2002 provided local authorities in New Zealand with a power of general competence (see Chapter 1) enabling them to undertake any lawful act to achieve their purpose, as long as it was not specifically proscribed or exclusively allocated to another agency. ${ }^{72}$ In doing so New Zealand came into line with what has become a modern approach to empowering local government. The New Zealand approach, primarily (B) but with some elements of $(\mathrm{C})$, is distinctive both for its lack of specific proscriptions and for the decision to separately prescribe taxing and bylaw-making powers, thus removing them from the general empowering provision. The LGA 2002, in particular, is designed in such a way that empowerment is tempered by the provision of opportunities for citizens to influence the decision-making processes of councils as well as applying what some within the sector regard as a 'heavy-handed' process compliance regime, such as the audit of the LTCCPs. Such compliance regimes can make councils risk averse. Generally, however, councils have a high level of operational autonomy with little ministerial ability to directly intervene in council affairs in a non-legislative way; however, this is gradually changing.

\section{Dimension assessment}

Community governance, with its emphasis on responsiveness, innovation and inter-agency co-operation, is more likely to be achieved in regimes where local government has constitutional recognition and general empowerment rather than an ultra vires framework. The current way in which local government in New Zealand is empowered, along with the requirement that councils consult with citizens and take their views into account when making decisions, should not provide any obstacles to achieving effective community governance. This dimension is assessed as adequate, even though parliament only needs a majority vote to change the sector's powers and role.

\section{Central government supervision}

This dimension examines the way higher level governments steer or direct local governments (see Chapter 4 for a theoretical discussion on 'steering styles').

\footnotetext{
${ }^{72}$ For example, the power to arrest or levy income taxes.
} 
There are two measures for this dimension: the degree of freedom councils have to set their own service delivery standards and central government's supervision style.

\section{Discretion to set service standards}

To what degree is New Zealand local government able to determine the quality and quantity of the services it is responsible for? Are councils an autonomous political sphere or part of the overall governmental structure, in which responsibilities are allocated nationally or locally on a pragmatic basis and delivered according to national parameters?

Autonomy can bee seen as sitting on a spectrum with integration at the opposite end (Montin 2000). Local government systems that sit at the autonomy end of the spectrum are characterised by self-government and a high level of freedom from intervention by state actors. For example, in systems with high degrees of autonomy national governments would not legally be able to override a properly made council decision. This autonomous model of local government reflects the traditional liberalism of writers, like John Stuart Mill, who regarded local and central government as distinct spheres of government within which central government should be restricted to only monitoring its activities (see Norton 1994). A similar approach is taken by Loughlin (1986), who describes a distinction between autonomists and functionalists. Advocates of the autonomist conception, while acknowledging the variable legal and constitutional restrictions that exist in different countries, focus on the potential within these systems for councils to exercise initiative and freedom of action. They tend to focus on the powers of local government, rather than the duties, and note that powers are often drafted in broad terms, consequently allowing considerable discretion (Stoker 2000, Filkin et al 2000, Reid 1999, Loughlin 1986).

A key factor in determining levels of autonomy is the discretion councils possess to set their own service quality and quantity levels, although these will vary across the different functions councils perform. Table 26 analyses a crosssection of New Zealand local government functions using three criteria to 
assess the level of autonomy in each functional area with criteria assessed as high, medium or low. The criteria are:

- degree of self funding - this criteria assumes that, in general, where an activity is funded locally or by the users, national direction is likely to be minimal

- council control over service quality - the ability to control the quality of a service, for example, the nature of new books added to the collection each year in city libraries, indicates local autonomy

- council control of service quantity - the ability to control the quantity of a service, for example, the number of libraries in a city, indicates a level of local autonomy.

Table 26 Autonomy index

\begin{tabular}{|l|l|l|l|l|}
\hline Function & $\begin{array}{l}\text { Council } \\
\text { control of } \\
\text { funding }\end{array}$ & $\begin{array}{l}\text { Council } \\
\text { control of } \\
\text { quantity }\end{array}$ & $\begin{array}{l}\text { Council } \\
\text { control of } \\
\text { quality }\end{array}$ & $\begin{array}{l}\text { Autonomy } \\
\text { index } \\
\text { ranking }\end{array}$ \\
\hline Libraries & High & High & High & High \\
\hline $\begin{array}{l}\text { Wastewater } \\
\text { treatment }\end{array}$ & Medium & High & Medium & Medium \\
\hline Water supply & High & Medium & Medium & Medium \\
\hline $\begin{array}{l}\text { Building } \\
\text { Control }\end{array}$ & High & Low & Low & Low \\
\hline $\begin{array}{l}\text { Recreation } \\
\text { centres }\end{array}$ & High & High & High & High \\
\hline
\end{tabular}

The sample of activities assessed above suggests that New Zealand councils have a high level of discretion for setting service levels, thus having a high autonomy index. However autonomy can vary according to function and policy arena. It also changes over time, reflecting ideology and the policy preferences of particular governments. 


\section{Supervision style}

In the first instance central-local government supervision is framed by the constitutional status of local government within the confines of any particular state. Local governments that have their role and powers defined by constitution have a status that councils in countries without such recognition struggle to achieve. New Zealand falls within the latter category. While it lacks a written constitution, it does possess a number of constitutional documents which both protect the rights and liberties of citizens and establish boundaries to the authority of public bodies. Statutes such as the LGA 2002, the LEA 2001 and LGRA 2002 can be understood as part of the country's constitutional framework. However, as a parliamentary democracy, local government's functions, funding and powers are set by simple majority vote in parliament, which has sovereignty. Council status is ultimately negotiated and depends on both the preferences of national policy-makers and the political skill of the sector itself. Without the 'security' of constitutional recognition, local authorities and their various representative organisations must work to build alliances among groupings within parliament in order to promote helpful measures or block legislation that might threaten its ability to govern effectively. ${ }^{73}$ However, constitutional recognition by itself is no guarantee that local government will possess the authority and capacity to exercise effective community governance. $^{74}$

One of the distinctive themes of the community governance literature features the relationship between levels or spheres of government. Focusing on outcomes, and recognising that many issues can only be addressed through a multi-agency response, highlights the importance of institutional frameworks governing relationships. A major factor affecting supervision style is the position systems sit on the autonomy/integration spectrum (see above). Location on the

\footnotetext{
${ }^{73}$ Political leverage is arguably diminished in the New Zealand model by the lack of overlapping political memberships. Systems such as the United Kingdom and the Republic of Ireland have considerable alignment between local and national political representation. Overlapping membership with parties represented in both Parliament and councils provides an additional mechanism for influence.

${ }^{74}$ While there is no guarantee constitutional recognition will enhance autonomy, councils still rate it highly. For example, the Australian Local Government Association unsuccessfully sponsored a national referendum in 1998, and in December 2008 launched a campaign for a second referendum.
} 
continuum is far from static. For example, many Nordic and European countries have gradually been shifting towards the integrated end of the continuum in recent years, largely reflecting the growth of the welfare state in the post-WWII period (Montin 2000). The integrational approach tends to emphasise the status of local authorities as creatures of statute and highlights the degree to which coproduction and co-management are a feature of many local public services (see Considine 2006), a view reinforced in contemporary debates about sustainable development. Integrated approaches can be characterised as either highly subordinated to the state or as partnering relationships. Subordinated relationships tend to be strongly hierarchical. In contrast, partnering allows some room for negotiation and may involve a situation where councils are the means through which governments implement decisions. These relationships reflect a 'co-operative dualism', which downplays hierarchical approaches and sets the scene for more of a sustained dialogue around innovations and their implementation (Banner 2002).

A related perspective is provided by Bailey (1999), who notes that central-local government relationships tend to be of two kinds. The first is the 'centralised constraint' model, in which central government sets the limits of council action within which they can act with full autonomy. The second is the 'bargaining' model, which occurs where local government's role is protected in a constitution, diminishing the ability of central government to direct local decision-making. In this latter case central governments need to negotiate compliance, increasing difficulties when seeking nation-wide compliance. In practice, relationships tend to be in a constant state of flux, reflecting changing perceptions of autonomy, accountability and micro-economic control. A good example is local government reform in Norway. Recently the Norwegian system has shifted from its historic tradition of autonomy to a more strongly integrational stance, an integrational model in which central government is now setting broad goals and structural frameworks while councils are determining the means for achieving the goals locally (Larsen and Offerdal 2000). ${ }^{75}$ In

\footnotetext{
${ }^{75}$ Recent reforms in New Zealand have similar characteristics with new regulatory regimes in building and food safety, for example, diminishing local discretion and strengthening the ability of national agencies to direct local authorities.
} 
essence, local government in Norway has become a "semi-autonomous political institution with a greater or lesser capacity for political action" with relationships that can be either of a principal-agent or partnership form (Montin 2000, p. 13).

The type of instruments used by national government to supervise their councils reflects a combination of constitutional arrangements, ideology and the historical circumstances which gave rise to local governance systems. For example, supervision in many European states is descended directly from Napoleonic traditions in which territorial offices of the state were set up to supervise local authorities (Sellers and Lidstrom 2007). The New Zealand framework is characterised by the use of 'softer' style supervision instruments, which reflects on the overall level of supervision councils are subject to from central government (see discussion in Chapter 4). Sellers and Lidstrom (2007) have developed an index which measures the degree of supervision local authorities in 21 OECD countries are subject to (see Table 27).

In developing their index the authors have used seven distinct indicators, these are: the existence of local supervisory officials; whether local executives are appointed by higher level governments or not; the level of local discretion in determining the form of local government; the degree to which the local and national civil services are integrated or exist independently; grants as a percentage of local revenue; local tax autonomy; and whether or not there is national supervision of local government borrowing (ibid 2007). Out of the 21 countries in the study, New Zealand ranks third from the bottom in terms of its level of local government supervision. The only countries with less 'supra local' fiscal and politico-administrative supervision are Switzerland and the United States. 
Table 27 Local government supervision

\begin{tabular}{|l|l|}
\hline Country & $\begin{array}{l}\text { Fiscal and politico-administrative } \\
\text { supervision (average) }\end{array}$ \\
\hline Denmark & 0.98 \\
Finland & 1.06 \\
Norway & 1.33 \\
Austria & 0.98 \\
Belgium & 1.45 \\
France & 1.59 \\
Germany & 1.29 \\
Italy & 1.26 \\
Netherlands & 0.93 \\
Switzerland & 1.26 \\
Greece & 0.52 \\
Portugal & 1.42 \\
Spain & 1.15 \\
Canada & 1.46 \\
Ireland & 0.56 \\
United Kingdom & 1.10 \\
United States & 1.23 \\
Australia & 0.38 \\
New Zealand & 0.64 \\
Japan & 0.53 \\
\hline
\end{tabular}

(Source: adapted from Sellers and Lidstrom 2007, p. 620)

The central-local government interface in New Zealand is a contested space that is yet to adapt fully to the implications of the LGA 2002. Nor is there necessarily a clear picture of the Government's intent, as Reid notes: 
The public rhetoric of empowering local government appears to have clouded what in practice is a tightening of accountability framed as empowering citizens to control their councils. In appearance it seems to indicate a failure to trust local democracy, i.e. locally elected representatives, to deliver desirable community outcomes without heavily prescribed process. ${ }^{76}$ How this balance, between empowered councils and empowered communities, is achieved will ultimately colour the potential for meaningful local governance arrangements in the future ${ }^{77}$ (Reid 2002, p. 337).

The nature of the interface varies by policy arena and there is some evidence to show that the Government is extending its policy interest and driving the New Zealand model, at least at the margins, towards the integration end of the spectrum. Compared with its international peers, such as European and Nordic local government systems, New Zealand's central government tends to have a lower profile, makes use of fewer national strategies that bind sub-national governments and is more likely to allow councils freedom to operate within their traditional policy realms. This statement must, however, be conditioned by an increasing use of national standards in some policy areas, particularly the environment and more top-down planning approaches in infrastructure. The growing use of 'standardising' measures (in the terms of the Dollery and Wallis $2001 \mathrm{~b}$ framework) points to a subtle shift from a largely autonomous to a more integrated form of local government. ${ }^{78}$

\section{Dimension assessment}

Despite the gradual shift in the New Zealand system towards the integration end of the spectrum, supervision of local government in New Zealand continues

\footnotetext{
${ }^{76}$ The Government's commitment to local empowerment was tested by whether or not it was willing to give councils the power to rate the hospitality industry, through what has become known colloquially as a 'room' or 'bed' tax. Although included in the Rating Bill it was removed at the last minute after widespread criticism by the hospitality industry concerned that councils will use it as a 'cash cow'. ${ }^{77}$ While the Government has made it clear publicly that the reform of the Local Government Act 2002 was not intended to address the constitutional relationship between local government and the national state, many commentators at the time thought the introduction of general empowerment had constitutional implications.

${ }^{78}$ The amendment to the Resource Management Act 2005 is expected to result in more national policy statements. Standards are also being imposed for services such as potable water, landfills, urban design and waste disposal.
} 
to be at the lower end of the supervision scale and would be unlikely to inhibit the necessary level of autonomy and responsiveness required to adopt a community governance approach. This dimension is assessed as adequate.

\section{Functions}

This dimension has been selected on the basis that the degree to which councils can directly influence the achievement of community outcomes has a direct bearing on their ability to exercise effective community governance and that being responsible for a broad range of functions increases their ability to influence outcomes. For example, councils with responsibility for health and education have more levers to enhance well-being than councils that lack such responsibilities. Consequently the range of mandatory functions undertaken by councils has been used as a measure along with the local government expenditure as a proportion of GDP and public expenditure.

\section{Local government expenditure}

The conventional explanation for the size of local government in New Zealand and its share of pubic services (approximately 10 per cent of public expenditure) refers to the country's small population and limited resources, which necessitated the active involvement of the state in the development of infrastructure (Bush 1995, Sutch 1956). Local government's share of public expenditure, however, has not always been so low. A revisionist history is emerging which focuses on local government's role in the creation of infrastructure and notes the frequency and scale of borrowing in foreign currency by councils in the 19th century. It explains the minimal role of local government and the country's strong centralism by reference to the Labour government in the 1930s and the emergence of the welfare state (Cookson 2007). Cookson writes that by 1930 local government accounted for almost half of total public revenue and expenditure, whereas by 2005 this figure had fallen to around 10 per cent (see Table 28). The trend was not unique to New Zealand; over the last century, the transfer of functions such as health, fire service and education from local to central government was mirrored by a 
similar centralisation in the British state and the erosion of local government powers in that country (Banner 2002).

Table $28 \quad$ Local government expenditure

\begin{tabular}{|c|c|c|c|}
\hline Country & Year & $\begin{array}{c}\text { Percentage of total public } \\
\text { expenditure }\end{array}$ & $\begin{array}{c}\text { Percentage of gross } \\
\text { domestic product }\end{array}$ \\
\hline Denmark & 1994 & $31.3 \%$ & $19.9 \%$ \\
\hline Italy & 1993 & $13 \%$ & $7 \%$ \\
\hline France & 1992 & $27.2 \%$ & $5.5 \%$ \\
\hline Netherlands & 1994 & $23.1 \%$ & $13.3 \%$ \\
\hline New Zealand & 2007 & $9.3 \%$ & $3.3 \%$ \\
\hline Norway & 1994 & $60 \%$ & $18.9 \%$ \\
\hline Sweden & 1994 & $38 \%$ & $27.5 \%$ \\
\hline United Kingdom & 1994 & $27 \%$ & $11 \%$ \\
\hline
\end{tabular}

(Source: adapted from Bailey 1999, p. 84)

While emergence of the welfare state, with its preferences for universal style policy solutions, signalled a reduction in the relative size of local government, the services provided by the sector have been dynamic. Over the first 50 years since their establishment, urban municipalities, in particular, expanded their activities in response to community demands. For example, Christchurch City Council invested in social housing as early as 1921 and established a crèche for shoppers a decade later. Wellington City Council not only employed the local concert master for the local orchestra (Wellington sinfonia), but also ran an abattoir. The diversity of functions can be seen to reflect a strong philosophy of localism and self-help that was part of the colonial experience. A similar trend also took place in rural New Zealand and by the time the Labour-Alliance government took office in 1999 very few rural councils in the South Island would not have been involved in the ownership or support of some form of rural medical centre. As central government reduced its presence in the provinces and downsized much of its traditional activity following 'deregulation', it was not uncommon for councils to find themselves filling the gap. A decade later the focus was more on working collaboratively to address 'wicked issues', such as 
graffiti and street racing. ${ }^{79}$ Despite the ability of councils to 'top up' or complement national services, in relation to its share of national and public expenditure the New Zealand local government system ranks as one of the smallest.

\section{Range of mandatory functions}

The range and scope of the functions councils are mandated (and empowered) to undertake represents one of the most important mechanisms through which they give effect to community governance. This occurs in two ways. In the first instance it ensures local authorities have responsibility for the provision (not necessarily as providers) of a sufficiently wide range of local services to enable them to enhance citizens' quality of life. In the second instance their ability to make decisions about the distribution, quality and quantity of services provides a degree of leverage which enables them to influence other sectors, such as the non-government sector. So what should these services be? Is there a particular range of functions or activities that are necessary if councils are to exercise local governance or is it simply a matter of scale? There are three perspectives:

1. activities or services which are the direct responsibility of the local authority. In relation to these services councils have rights as owners and funders to determine quality, quantity and strategic objectives

2. activities or services provided under a mandate from national governments. Many of these functions fall into the 'maximalist' category described in Table 30, and are either funded or closely monitored by the state. Inevitably, decisions about quality and quantity are determined by the funders, diminishing the ability of councils, as providers, to tailor services to address unique and local circumstances. This is the case in centralised states like the United Kingdom and is a growing issue in decentred states like Norway and Denmark

3. mechanisms to influence other providers. Such mechanisms may include the power to establish local regulations (unfettered by higher levels of

\footnotetext{
${ }^{79}$ Such was local government's response that the Minister of Local Government, the Hon. Maurice Williamson, was heard complaining that 'just because central government has stopped delivering a service is no excuse for local government to get involved", conversation with the writer, 1998.
} 
government); advocacy through the application of 'bully pulpit' powers (usually exercised by political leaders); and the use of joint planning/operations, such as the community development strategies employed in Ireland and both Strategic Local Partnerships and the Sustainable Communities Act adopted by the United Kingdom.

Does the current suite of local government functions enable or inhibit community governance? Is the emphasis on property-related services too limiting? In a comparative study of functions, Gough (2009) argues property and amenity functions are essential for councils to undertake their place-shaping role (see Lyons 2007). Table 29 extends Gough's study with the addition of New Zealand data. 
Table 29 Analysis of local government functions

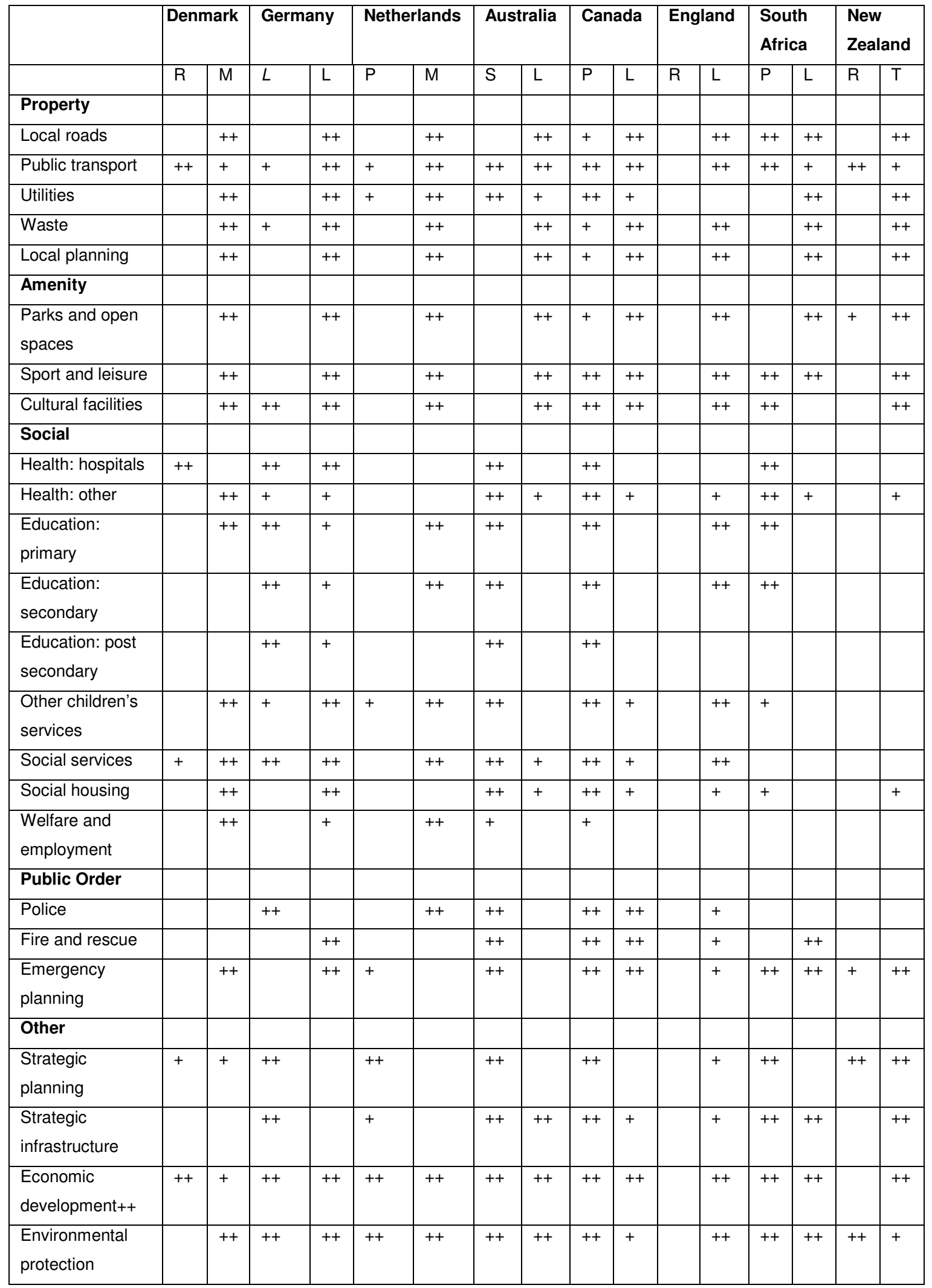




\begin{tabular}{|c|c|c|c|c|c|c|c|}
\hline++ & Strong role & \multicolumn{2}{|c|}{ Germany } & \multicolumn{2}{|c|}{ Australia } & \multicolumn{2}{|c|}{ South Africa } \\
\hline+ & Modest role & $\mathrm{L}$ & Lander & $S$ & States & $\mathrm{P}$ & Provinces \\
\hline \multicolumn{2}{|c|}{ Denmark } & L & Local & $\mathrm{L}$ & Local & L & Local \\
\hline $\mathrm{R}$ & Regions & \multicolumn{2}{|c|}{ Netherlands } & \multicolumn{2}{|c|}{ England } & \multicolumn{2}{|c|}{ New Zealand } \\
\hline \multirow[t]{2}{*}{ M } & Municipalities & $\mathrm{P}$ & Provinces & $\mathrm{R}$ & Regional & $\mathrm{R}$ & Regional \\
\hline & & M & Municipalities & $\mathrm{L}$ & Local & $\mathrm{L}$ & Local \\
\hline
\end{tabular}

(Source: adapted from Gough 2009, p. 23)

As Gough's work indicates, the New Zealand model is strong in relation to property, amenity and other activities; however, it is particularly weak when compared with most other countries with regard to social and public order activities. Missing from the New Zealand bundle of functions are any of the major social policy functions, such as policing, education, social services and health. The small range of decentralised services provided by local government in this country emphasises the Anglophone nature of the local government system (Norton 1994). Anglophone systems tend to take an instrumental view of local authorities as service providers, reflecting greater levels of central government oversight, minimal constitutional safeguards and, in many countries, strong agency roles. Councils in Anglophone regimes are seen in similar terms to the private or the not-for-profit sectors, whereas, in contrast, continental systems view local authorities as having general responsibility for local affairs (Banner 2002). This is illustrated in Figure 10, which compares autonomy and tasks in a range of cities. Christchurch, one of the largest cities in New Zealand, scores highly for autonomy but poorly for task profile. 
Figure 10 Task profile for selected cities ${ }^{80}$

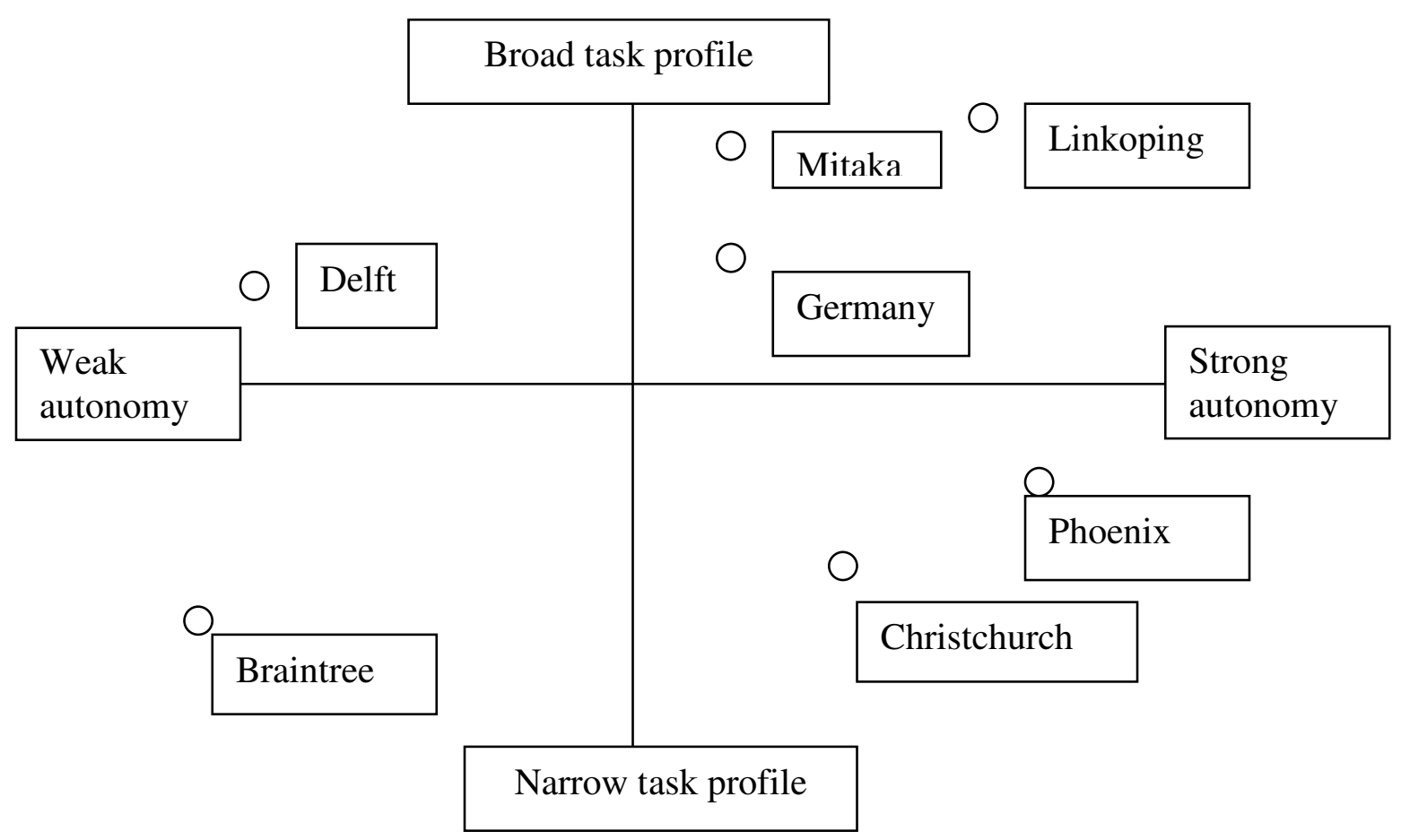

(Source: adapted from Naschold 1996, p. 11)

The discussion about functions is partly obscured by the difference between production and provision. Having a statutory responsibility to ensure a service is provided does not mean that councils should be the provider. Indeed, commentators like Osborne and Gaebler (1992) argue that the more that councils are forms of local administration (the functionalist perspective) the less able they will be to take a strategic governance approach. While their rowing/steering metaphor may have become clichéd, the suggestion that too much emphasis on 'rowing' rather than 'steering' can inhibit organisations from focusing on the 'big picture' has particular salience at the level of local government, where infrastructure and asset management contribute a significant part of an authority's budget.

Naschold's (1997) solution to this issue is for councils to be 'smart purchasers', an idea that envisages an environment in which they have the freedom to reallocate resources to address strategic priorities without being bound to a

${ }^{80}$ Naschold 1997, p. 12. 
particular bundle of services. In a similar vein, the New Local Government Network (2008) argues, with reference to the United Kingdom, that councils need to be sufficiently empowered in order to shape the service outcomes of other public organisations, such as the police and health authorities. This requires governments to reform "local democracy to empower councils to offer multi-functional democratic oversight of public services across the local place" (Filkin et al 2008, p. 4). It places more emphasis on their role directing development rather than necessarily providing services and highlights the need to be able to take a strategic view of governance.

Internationally there is a high degree of convergence around a core set of local services (Table 30 describes these as minimalist) with many systems, for example the Northern and Southern European models, delivering a much broader range, particularly social services (maximalist). Table 30 defines both minimalist and maximalist systems.

Table $30 \quad$ Local government functions

\begin{tabular}{|l|l|}
\hline Minimalist & Maximalist \\
\hline Libraries & (In addition to the minimalist list) \\
Sports, recreation and cultural facilities & Primary education \\
Local physical planning & Secondary education \\
Local roads & Child care \\
Emergency services & Hospitals \\
Drinking water & Social services \\
Sewerage & \\
Drainage & \\
Public health services & \\
\hline
\end{tabular}

Maximalist systems, such as the Danish system, can directly influence local outcomes by adjusting expenditure or amending service levels for the activities for which they are responsible. Local authorities in minimalist systems have less ability to directly influence outcomes, as many of the major policy arenas, such as health, are the responsibility of central government. In practice, the 
distinction between the two types of system is not a zero sum game. Maximalist systems, such as those in Denmark and the United Kingdom, while putatively responsible for a wide range of local services, also operate within national policy frameworks set by their national governments that limit local discretion, require national standards and limit councils' tax-raising powers.

\section{Dimension assessment}

While the New Zealand framework enables councils to undertake a broad range of discretionary activities, this measure highlights the system's minimalist range of mandatory functions and proportionally low share of public expenditure. It argues that both these factors limit the ability of councils to influence local outcomes (acknowledging that many councils have shown significant ability through collaborative arrangements or good advocacy; however, not all are able to exercise such choices). This dimension is assessed as having room for improvement.

\section{Strategy}

This dimension is concerned with the degree to which councils' approaches to strategic planning have a community planning focus, that is, they are externally focused and provide a framework for a range of agencies to pursue common objectives set by citizens. The measure for this dimension uses the English and Irish approaches to community planning as comparators with which to evaluate the New Zealand approach.

Traditional strategic planning seeks to place an organisation within its wider context and position it for the future. More recently, issues-based and inductive approaches to strategy have been recognised (Bryson 2004) that address 'wicked issues', issues that require an inter-agency response. As an approach to strategy this new version extends beyond the organisation and involves a much broader range of actors, akin to what Reich describes as a process of social learning about public problems and possibilities (see Roberts 2000). Community planning is distinctive because it links vision to well-being and 
seeks to achieve community buy-in to that vision in order to gain legitimacy (Moore 1995). There are three stylised models of strategy (see Table 31).

Table $31 \quad$ Strategy models

\begin{tabular}{|c|c|c|c|c|c|}
\hline & $\begin{array}{l}\text { Council } \\
\text { orientation }\end{array}$ & $\begin{array}{l}\text { Strategic } \\
\text { focus }\end{array}$ & $\begin{array}{l}\text { Degree of } \\
\text { feedback }\end{array}$ & $\begin{array}{l}\text { Linkages to } \\
\text { citizens and } \\
\text { other } \\
\text { organisations }\end{array}$ & $\begin{array}{l}\text { National } \\
\text { approaches }\end{array}$ \\
\hline $\begin{array}{l}\text { Approach } \\
\text { one }\end{array}$ & $\begin{array}{l}\text { Focus on } \\
\text { service to } \\
\text { community }\end{array}$ & $\begin{array}{l}\text { Primarily } \\
\text { internal } \\
\text { strategic } \\
\text { alignment }\end{array}$ & $\begin{array}{l}\text { Councils } \\
\text { periodically } \\
\text { test strategy } \\
\text { against } \\
\text { community } \\
\text { outcomes } \\
\text { (primarily } \\
\text { efficiency). }\end{array}$ & $\begin{array}{l}\text { Service delivery } \\
\text { outputs } \\
\text { consistent with } \\
\text { citizen } \\
\text { expectations } \\
\text { (community } \\
\text { outcomes reflect } \\
\text { them) }\end{array}$ & $\begin{array}{l}\text { South } \\
\text { Australia } \\
\text { Norway }\end{array}$ \\
\hline $\begin{array}{l}\text { Approach } \\
\text { two }\end{array}$ & $\begin{array}{l}\text { Focus on } \\
\text { services and } \\
\text { other } \\
\text { functions to } \\
\text { support } \\
\text { community } \\
\text { well-being }\end{array}$ & $\begin{array}{l}\text { Focus on } \\
\text { internal and } \\
\text { external } \\
\text { strategic } \\
\text { alignment }\end{array}$ & $\begin{array}{l}\text { Ongoing } \\
\text { testing for } \\
\text { alignment } \\
\text { between } \\
\text { outputs and } \\
\text { outcomes } \\
\text { (efficiency and } \\
\text { effectiveness) }\end{array}$ & $\begin{array}{l}\text { Community } \\
\text { outcomes shape } \\
\text { service delivery } \\
\text { and other roles } \\
\text { including } \\
\text { collaboration } \\
\text { with others. }\end{array}$ & $\begin{array}{l}\text { Republic of } \\
\text { Ireland }\end{array}$ \\
\hline $\begin{array}{l}\text { Approach } \\
\text { three }\end{array}$ & $\begin{array}{l}\text { Community } \\
\text { engagement } \\
\text { and } \\
\text { collaboration } \\
\text { underpin } \\
\text { strategic } \\
\text { development. }\end{array}$ & $\begin{array}{l}\text { Focus on } \\
\text { external } \\
\text { alignment, } \\
\text { outcomes, } \\
\text { common } \\
\text { purpose }\end{array}$ & $\begin{array}{l}\text { Feedback } \\
\text { loops allow } \\
\text { iterative } \\
\text { strategy } \\
\text { development. }\end{array}$ & $\begin{array}{l}\text { Councils and } \\
\text { communities co- } \\
\text { produce } \\
\text { outcomes (with } \\
\text { others). }\end{array}$ & $\begin{array}{l}\text { New Zealand } \\
\text { United } \\
\text { Kingdom }\end{array}$ \\
\hline
\end{tabular}

(Source: adapted from Scott 2008, unpublished paper prepared for Local

Futures, 2008)

The three approaches are distinguished by the degree to which they are internally or externally focused and how they link or align with other organisations. Approach three reflects the core premise of an outcomes- 
focused community strategy, in which the council works with other parts of the community to 'co-produce' outcomes, direction is set on the basis of community engagement and common purpose is built around agreed outcomes. Community strategies are processes for identifying community aspirations in order to provide goals around which locally and nationally based organisations can organise and establish common purpose. The concept underpins much of the writing about community governance (see Stewart and Clarke 1996, Considine 2006). As Darlow et al note:

Increasingly community strategies are being assigned the role of the key strategic document in localities. As such they are intended to provide the vision and strategic framework for other local plans and strategies and, more recently, they have also been given a key role in relation to 'place shaping' (Darlow et al, 2008, p. 9).

In community planning the overall goal is not the success of the organisation itself, the local authority, but the well-being of the community it serves. This is one of the specific objectives of the Irish approach. Following the implementation of a public sector modernisation strategy in the late 1990s, the 'Strategic Management Initiative', the Irish Government introduced a range of measures to maximise local government's contribution to economic and social development, excellence in service delivery and more effective services. As a result of greater decentralisation, local government found itself playing a broader role in the integration and co-ordination of public services, a move described by that government as having "set a path which should enable local government to influence, to a much greater extent, the provisions of public services locally" (Department of Environment and Local Government (DELG) 2000. p. 7). The Irish initiative was intended to address the siloed behaviour of public services and the perceived difficulty of delivering a joined-up approach for dealing with complex issues. The Department of Environment and Local Government (DELG) noted that the problem of co-ordination is felt most acutely at the local level "due to the relatively narrow range of functions entrusted to the local government system" (DELG 2003, p. 5). To achieve collaboration, the government established what it termed County/City Development Boards 
(CDBs) as mechanisms for "local government, local development, state agencies and the social partners, to work out an agreed vision for their county or city" (DELG 2000, p. vii).

The primary task of the boards is to produce a strategy to address the economic, social and cultural development issues within their jurisdictions and the first strategies were to be completed by the beginning of January 2002. Chaired by a nominee of the county/city councils the boards were set up to operate autonomously but under the local authority umbrella. The Minister of Local Government explained that the boards drew on the traditional Irish concept of Meitheal, or working together, and would bring together all players locally - the public sector agencies, the social partners and, most importantly, local communities and the voluntary sector to seek common cause in developing their counties and cities (Dempsey 2000).

The CDBs, which were recognised within the government's National Development Plan, were expected to deliver four objectives:

- work towards an agreed county/city strategy for economic, social and cultural development

- develop a vision at local level to encompass the various local and sectoral plans

- provide for co-operation on a continuing basis at county/city level in the work of the various agencies, promote co-ordination and avoid overlap at this level

- maximise the effectiveness of spending on programmes and projects at the local level by bringing together the various interests (ibid, p. 2).

More specifically, the aim of the boards includes the joint development and monitoring of locally delivered public services; minimising overlaps and duplication; filling service gaps; achieving a more coherent and integrated approach to public and local development; and addressing the particular needs of local areas (DELG 2003). The government's review of the first round of 
strategies, undertaken in mid 2002, noted that all 34 integrated strategies for the delivery of local public services had been adopted and published and that they represented a new approach to the task of achieving more 'joined-up' government at the local level in Ireland. However, while the strategies were seen to make a positive contribution to improved public service co-ordination, success was still dependent on the willingness of central agencies to shift beyond token compliance and seriously resource the new strategies (DELG 2003). As the review commented:

The county/city level cannot go very far past where the central level wishes or allows it to go. So, for the central level, the key message of the strategies is that the local service integration mission will ultimately be as successful or unsuccessful as central government organisations wish it to be (ibid, p. 81).

Although participating public agencies are required to commit resources to the achievement of the new strategies, compliance appears to vary according to the interest of each agency, a theme that would appear to be universal.

Sustainable community strategies, introduced by the Local Government Act 2000 (LGA 2000), played a critical role in the United Kingdom's modernisation agenda. Local authorities, acting in association with other local agencies through Local Strategic Partnerships (LSPs), are required to prepare sustainable community strategies, the key strategic document for setting out area visions. This was announced early in the government's reform programme: the "new duty to promote well-being will include a requirement for councils to secure the development of a comprehensive strategy for promoting the wellbeing of the area" (DETR 1998, p. 81). The purpose of such strategising was intended to create local leadership that "joins-up the efforts and vision and commitment of others but does so by respecting and supporting the contribution of other stakeholders, citizens and providers" (Filkin et al 2000, p. 14). The statutory objective of sustainable community strategies is to promote or improve the well-being of the council's area. They are required to include four key 
components - a long-term vision, an action plan, commitment to improvement, and arrangements for monitoring and implementation - and are expected to:

- enable communities (based upon geography and/or interest) to articulate their aspirations, needs and priorities

- co-ordinate the actions of the council with those of the public, private, voluntary and community organisations that operate locally

- influence the activities of those organisations so that they effectively meet community needs and aspirations

- contribute to the achievement of sustainable development with local goals and priorities relating to appropriate regional, national and global objectives (DETR 1998).

The strategies are described as the "overarching plan for promoting and improving the well-being of the area" (Communities and Local Government 2008, p. 28). The structure is set out in Figure 11. 
Figure 11 The United Kingdom's strategic framework

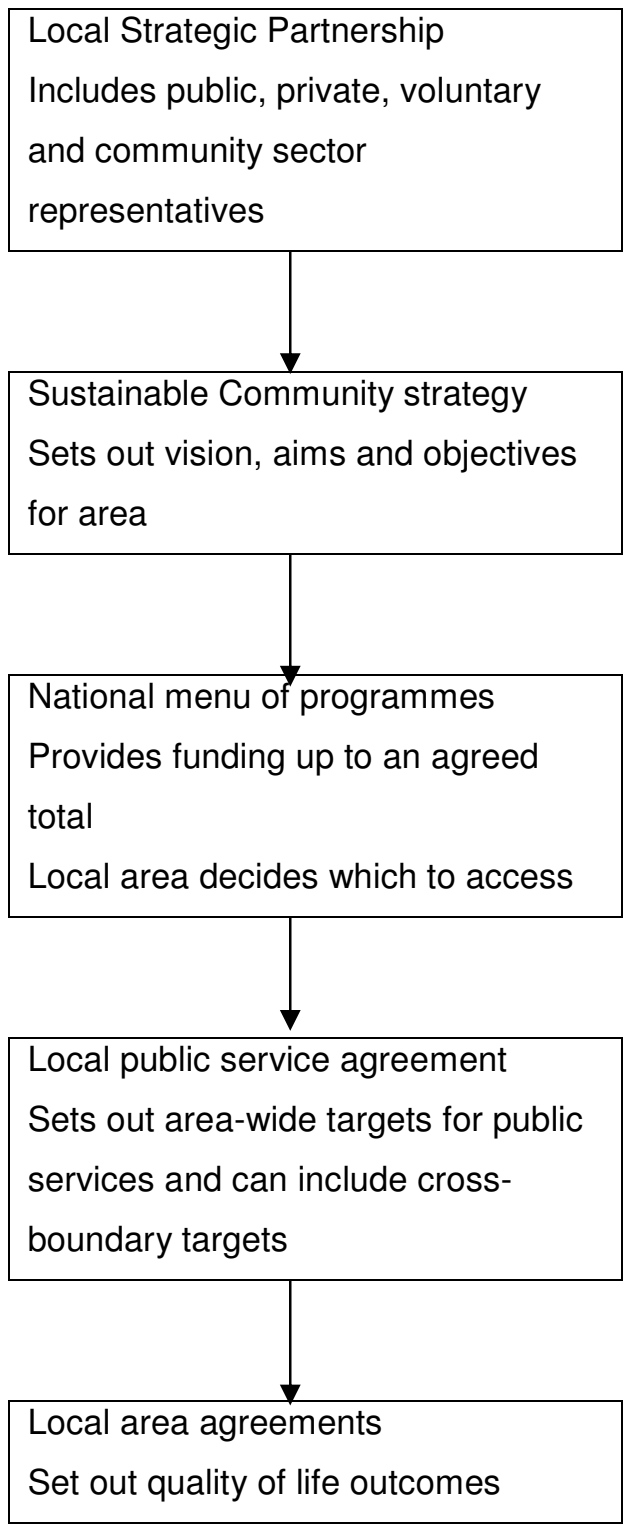

Consultation with users and different sectors
Local/regional/national priorities agreed
Single monitoring process for areawide outcomes

(Source: adapted from Audit Commission 2004)

The United Kingdom's approach to community planning sits within a framework of collaborative and inter-agency initiatives. In 2003 the Egan review (ODPM 2003) recommended that community strategies be expanded into what are now known as sustainable community strategies. The councils' lead role was to orchestrate the delivery of sustainable communities by bringing together service providers and other players within the local community. 
The New Zealand approach to community planning is described in previous chapters. In essence, councils are required to facilitate a process to identify community outcomes and develop 10-year plans which indicate how they will contribute to those outcomes. The legislation is prescriptive in requiring councils to use their best endeavours to invite other agencies, those which contribute to the achievement of community outcomes, to take part in designing the process for essentially identifying them. Outcomes also feature in at least two other important aspects of the LGA 2002, notably the requirement to prepare a report every three years showing the degree to which the outcomes have been achieved and in the second instance they must show how certain kinds of decisions made by the council contribute to the achievement of community outcomes. The models used in Ireland and the United Kingdom provide a useful template against which to assess the New Zealand approach (see Table 32).

Table 32 Approaches to strategy

\begin{tabular}{|c|c|c|c|}
\hline & Ireland & England & New Zealand \\
\hline Prescribed process & High & Medium & Low/medium \\
\hline $\begin{array}{l}\text { Involvement of public } \\
\text { agencies mandatory }\end{array}$ & Yes & Yes & No \\
\hline $\begin{array}{l}\text { Involvement of non- } \\
\text { public agencies } \\
\text { mandatory }\end{array}$ & Yes & Yes & No \\
\hline Policy scope & Limited & Wide & Wide \\
\hline $\begin{array}{l}\text { Incentives to encourage } \\
\text { joined-up governance }\end{array}$ & Mandatory & Yes & No \\
\hline Citizen influence & Moderate & High & Moderate \\
\hline $\begin{array}{l}\text { Structures for joined-up } \\
\text { governance }\end{array}$ & Yes & Yes & No \\
\hline $\begin{array}{l}\text { Influence of the } \\
\text { strategies }\end{array}$ & $\begin{array}{c}\text { Individual } \\
\text { agencies required } \\
\text { to have regard to } \\
\text { strategies }\end{array}$ & $\begin{array}{c}\text { Form the basis } \\
\text { for LAA } \\
\text { priorities }\end{array}$ & $\begin{array}{l}\text { Depends on } \\
\text { individual } \\
\text { agencies }\end{array}$ \\
\hline
\end{tabular}


The Irish model emphasises the co-ordination of public services on a regional basis. It brings together representatives from specified agencies, both public and non-public partners, in order to reduce duplication and enhance integration, providing a balance between national strategies and local issues. In contrast, the United Kingdom's approach to developing and implementing sustainable community strategies tends to emphasise the articulation of local aspirations. These act as a mechanism to identify priorities that form the basis of a range of joined-up initiatives at the operational level. In the Irish Republic the local authority is required to develop the strategies, while in the United Kingdom responsibility sits with the LSP, although the council is still the default provider should local strategic partnerships not be established. Even where LSPs have been established, local authorities tend to be the major agency.

The New Zealand approach contains many similar elements to both Ireland and the United Kingdom; however, it lacks the high level national commitment to collaboration found in those countries, particularly with the voluntary nature of central government agency participation. Most efforts have focused on the process for identifying community outcomes. The approach taken to the identification of community outcomes has varied between councils and different approaches were also taken to the involvement of third party organisations and in the degree to which outcomes have been highly summarised. A study of community outcomes undertaken by the Department of Internal Affairs (see www.communityoutcomes.govt.nz) notes that most councils have identified between six and eight high level outcomes; however, some had more than 40 outcomes, for example Wellington City and Ruapehu District. As an example of this diversity, some councils, such as Wellington City, have also developed their own council outcomes which act as intermediary outcomes to assist with their internal planning (see Chapter 5).

Although the LTCCP is designed to be outcome-focused, questions exist as to the degree this has been achieved in practice: "New Zealanders have failed to fully grasp the opportunity that informed deliberative community-based engagement offers as a forum for community governance mandated under the LGA" (Leonard and Memon 2008, p. xi). Problems include: 
- a failure by both local and central government to understand the full significance of the paradigm shift that was the LGA 2002. As a result the promise of the community outcomes process has not been realised

- a failure to appreciate the importance of taking a participatory approach to the community outcomes process and to develop 'intermediate' outcomes which would better replicate the 'managing for outcomes' approach of central government departments

- a failure to ensure those participating in the community outcomes process, such as elected members and staff, were adequately informed "of the substantive issues in the community" (ibid, p. xii)

- the lack of understanding about the collective ownership of community outcomes by community and business sectors and a general lack of resourcing for such sectors, along with Maori, to adequately participate.

A further issue is the effect of the audit regime. LTCCPs are subject to an audit opinion commenting on the underlying assumptions of the plan and the accuracy/quality of its performance management system. The result has been a greater focus on compliance and meeting the requirements of the audit than deliberative strategy. Underpinning many of concerns is a belief that councils were not given sufficient guidance to implement the new focus on outcomes adequately, as well as a lack of national leadership to champion the new community outcomes paradigm, both within the government and in the community and local government (see Leonard and Memon 2008). Other concerns have been raised by Local Futures, a research consortium, who suggested that the approach to framing outcomes taken by most councils resulted in "high level outcomes (which) cannot provide effective tools for guiding local decision-making" (Local Futures 2006, p. 208). Local Futures also expressed concern that the majority of councils tended to use passive methods for identifying outcomes, such as surveys, rather than deliberative processes involving extensive citizen engagement, the result being akin to a list of issues, rather than a considered vision of the future. In addition, the case studies (see Chapter 5) found that the New Zealand approach to identifying community outcomes fell short of the community governance approach for two reasons: the 
difficulty of ensuring they reflect community-wide aspirations and the lack of any mandatory role of central government agencies and departments.

\section{Dimension assessment}

The New Zealand framework nominally meets the requirement that councils focus on community-wide outcomes rather than organisationally focused outputs. However, the value of outcomes-based strategy is overshadowed by the more compliance-focused expectations of the LTCCP, particularly its emphasis on being an accountability document, asset management plan and performance framework. This is also reinforced in the findings of Chapter 5 , which highlight a divergence between those councils that see the LTCCP and community outcomes as a compliance matter and those that see it as providing an opportunity to enhance community governance.

In effect the LTCCP's broad range of statutory objectives has 'crowded out' strategy. In addition, the manner in which the framework has been interpreted and the lack of prescription around the framing of outcomes limit the potential for achieving effective collaboration. And compared with both the Irish and the English approaches to community planning the New Zealand framework was found wanting in some areas. Consequently, this dimension is assessed as showing room for improvement.

\section{Leadership}

The leadership dimension is one of the critical elements of community governance theory, particularly the leadership role played by local authorities in steering the strategic decisions of other sectors. The role of the mayor is critical to the nature of local leadership and the measure for this dimension asks whether or not the role of mayor in the New Zealand model has the authority to fulfil the leadership expectations found in community governance theory.

Community governance theorists see councils as 'first among equals' and highlight the importance of their democratic base as providing legitimacy to their leadership aspirations. This extra-organisational model of leadership has been 
conceptualised in a number of different ways. For example, in their publication on the future of local government, the Office of the Deputy Prime Minister in the United Kingdom (ODPM 2004) describes strong leadership as including:

- being enablers of the community, which involves standing up for, learning from and empowering local people, including the most vulnerable

- being champions of the area, which includes building a vision, setting a clear direction and ensuring it is delivered

- being challengers and scrutineers of public services more generally

- being shapers of services around the citizen, including forging local partnerships

- making decisions and setting priorities as well as being accountable for making tough decisions when balancing competing demands.

While the official advice from the United Kingdom government reflects a change in the way leadership is understood, so has the context changed. The modern policy context finds itself concerned with community fragmentation, a more demanding citizenry and a more challenging media. These have resulted in a different type of political leadership which is more facilitative (Greasley and Stoker 2008). Leaders as facilitators tend to have strong partnership skills, low partisanship (which means they would be able to work across political boundaries) and are visible and easy for citizens to engage with. Such politicians are outward looking and focused on streamlined decision-making to ensure momentum. Drawing on their own research Greasley and Stoker conclude that directly elected mayors in the United Kingdom are more likely to meet the criteria of facilitative leaders than mayors in leader-cabinet models, the traditional form of local government in the United Kingdom. ${ }^{81}$

\footnotetext{
${ }^{81}$ Councils in the United Kingdom have the choice of three governance models: directly elected mayors, leaders and cabinets in which the leader is chosen by colleagues, and the traditional committee structure with indirectly elected leaders.
} 
The New Zealand system of local government contains what is generally known as the 'weak mayor' model (that is, mayors have no executive authority, with the exception of the new Auckland mayor) (see Table 33).

Table 33 Weak/Strong mayors

\begin{tabular}{|l|l|}
\hline \multicolumn{1}{|c|}{ Weak model } & \multicolumn{1}{c|}{ Strong model } \\
\hline No executive authority & Full executive authority \\
\hline $\begin{array}{l}\text { No formal influence on senior } \\
\text { staff appointments }\end{array}$ & Right to appoint senior staff \\
\hline Strict separation of roles & May also act as chief executive \\
\hline $\begin{array}{l}\text { Deputy mayor and committee } \\
\text { chairs appointed by majority } \\
\text { council vote }\end{array}$ & $\begin{array}{l}\text { Can select deputy mayor and } \\
\text { committee chairs }\end{array}$ \\
\hline $\begin{array}{l}\text { Spokesperson roles often } \\
\text { shared }\end{array}$ & Council spokesperson \\
\hline
\end{tabular}

In the New Zealand model, mayors gain their authority from the fact that they are directly elected more than from the powers conferred by statute. In fact the main statutory role that distinguishes mayors from councillors is their right to preside over council meetings, to be an ex officio member of council committees and, in some councils, to exercise a casting vote. ${ }^{82}$ In contrast, the strong mayor model, also known as the executive mayor model, is common in the United States and essentially combines the role of mayor and chief executive.

On the basis of their democratic mandate New Zealand mayors wield considerable symbolic authority but can only exercise coercive powers when empowered by a decision of their council. Their success depends on their ability to craft coalitions of councillors around policy and topical issues. Unfortunately it is not uncommon for a mayor to be elected to a hostile council, in which they

\footnotetext{
${ }^{82}$ The LGA 2002 removed the automatic right of mayors to exercise casting votes. After vigorous lobbying by local government, the government amended the statute to make it discretionary. Most councils have amended their standing orders to provide for a casting vote. Mayors also have some specific powers under other legislation; for example, they are automatically Justices of the Peace and are entitled to declare a local emergency.
} 
are a political minority, and for his or her term to be marked by ongoing conflict with councillors, leading to an inevitable erosion of credibility and effectiveness. Even when mayors succeed in building alliances, accountability is relatively opaque, unlike the strong mayor model. In her thesis on the role of a mayor, Margaret Evans, a former mayor of Hamilton in New Zealand, argues that the LGA 2002 should be amended to prescribe the specific roles mayors carry out, particularly their leadership roles in relation to governance, policy and the community (Evans 2003). Included in the changes Evans seeks are:

- giving mayors the right to appoint their deputies and committee chair people

- giving mayors the sole right to delegate their role as presiding member

- allowing mayors to recommend governance structures and processes, memberships and delegations

- giving mayors responsibility, on behalf of the council, to ensure chief executives implement council policy (ibid, p. 2003).

Evans' proposals would provide the mayor with greater responsibility for overseeing the operation of local authorities in a way that would shift the role of councillors to largely scrutinising the mayor's performance, mirroring in a way the governance arrangements of the Greater London Authority. ${ }^{83}$ The suggestion that strong leadership needs to be based on more than simply popular support, and that it should also have the authority to 'do things', is popular in the debate surrounding the review of Auckland's governance arrangements (see the Report of the Royal Commission on Auckland Governance 2009). In the view of the commission a strong leader for metropolitan Auckland is necessary to get the city moving (literally), provide a sense of direction and improve political accountability, although not in isolation. Whether such strong leadership will provide the answers to Auckland's problems, with which the Royal Commission has been tasked, will be a matter of future record, as Hambleton notes:

\footnotetext{
${ }^{83}$ The Royal Commission's report recommends that the new mayor of metropolitan Auckland should have all the powers recommended by Evans.
} 
An important challenge for all political leaders is to develop their skills and effectiveness as facilitative leaders, rather than top down leaders. The importance of being able to reach out to other stakeholders and local people in an effort to influence decisions made by others in order to improve the local quality of life is difficult to over-estimate. Modern leaders ... use the legitimacy of their elected position to orchestrate new approaches to metropolitan leadership (Hambleton 2008, p. 12).

Given the nature of community governance, involving leadership and building alliances and networks with independent and quasi-independent sectors, it is not clear that having executive authority is a necessary factor of success. As Greasley and Stoker (2008) suggest, the necessary skills are more concerned with facilitation and trust building than the provision of direction. In some respects a weak regime may even be an advantage as strong mayor regimes tend to have fewer checks and balances on the exercise of their authority, are less transparent and can become characterised by a more traditional culture of hierarchical decision-making and nepotism.

The New Zealand legislation is silent on the role of a mayor. Indeed, the review of the LGA 2002 was also silent on the much broader question of political leadership, with more emphasis being placed on providing citizens with the 'tools' to limit the discretion of their local political representatives than strengthening them. ${ }^{84}$ One comment frequently heard in the wake of the passage of the LGA 2002 was that the Government was trying to weaken representative democracy by promoting participatory democracy, with councillors feeling that the changes, such as the role of citizens and other organisations in the identification of community outcomes, undermined their role. Seven years on, it is not clear that the role of elected members has been weakened although the political decision-making space has become considerably more complex.

\footnotetext{
${ }^{84}$ The 'leadership' word is almost invisible in the policy and discussion documents associated with the LGA 2002, in contrast with the similar review in the United Kingdom.
} 


\section{Dimension assessment}

With its tradition of directly elected mayors, New Zealand is still well placed to exercise the form of civic leadership espoused by community governance theorists; however, it is not a role that is as understood and valued as it might be. The lack of any articulation of the mayors' community leadership function in the LGA 2002, coupled with the lack of any executive authority, means that this dimension is assessed as showing room for improvement.

\section{Collaboration}

This dimension is concerned with whether or not the legislative framework governing local government is conducive to strong collaboration. Collaboration is one of the central ideas underpinning the community governance paradigm in the sense that the art of governing includes managing relationships involving independent agencies and organisations. As a collective noun, 'collaboration' refers to a range of phenomena from "wide networks through loose alliances and tight federations to the creation of novel organisational entities, sometimes separate from the partner organisations, sometimes vested in one partner" (Cropper quoted in Sullivan et al 2006, p. 291). It also refers to behaviours as well as structures. The measure for this dimension is the existence or otherwise of formal or semi-formal structures for giving effect to joined-up initiatives at the local level.

By the end of the $20^{\text {th }}$ century the idea that joining up government was somehow necessary and desirable had become almost conventional wisdom in New Zealand, particularly with the publication of a number of critical reviews commenting on the problem of public sector silos (Schick 2001, Logan 1991). It was an idea that was given further elevation with the release of The Review of the Centre and its follow-up report, The Review of the Centre One Year On (SSC 2001 and 2002). These reports highlighted a lack of co-ordination and alignment between departments and public agencies which was regarded as a weakness in the New Zealand public sector model. The Review of the Centre noted that: 
a number of stakeholders and commentators ... emphasised the need for clarity on directions and expectations, particularly in relation to issues or intentions impacting across sectors or the whole of government. Weaknesses include ... the fragmentation of the sector which makes it difficult to actively pursue cross cutting objectives (The Review of the Centre, SSC 2001, p. 14).

The suggestion that strategy should be extended beyond the core public sector was developed in the Commission's follow-up report (The Review of the Centre One Year On, SSC 2002). In this report the State Services Commissioner argued that the public service needs to get closer to citizens and the community, and agencies have to work together with communities outside Wellington (ibid). Similar themes were echoed in the review of the LGA 1974 , where issues of collaboration and partnerships were underpinning themes, themes that extended beyond central and local government to include Maori organisations and the not-for-profit sector (DIA 2000 and 2001).

Similar discussions had been taking place within local government circles some years before the Labour-Alliance Government was formed. The notion of a democratically legitimate system of local government working collaboratively with other systems of government and emphasising community resilience found a home in the pre-election manifestos of both parties. These manifestos emphasised the idea of 'partnership', particularly with reference to intergovernmental relationships. 'Partnership' provided both a familiar and politically important term for describing these desired relationships, including the goal of more integrated public decision-making. Thomas and Memon (2007) argue that the rise of a partnership discourse can be directly attributed to the influence of third way political thinking. Commenting on the New Zealand approach they argue that:

third way leaders sought to address the breakdown of the social and spatial contract through the revitalisation of community, to balance the authority of central government, so that a measure of democratic 
accountability might be returned to the local level. Naturally local government was a logical tool to form a partnership with local communities and thereby empower them. Thus there was a natural synergy between the turn to governance and the agenda of the Third Way (Thomas and Memon 2007 p. 20).

In a similar vein, official documents preceding the enactment of the LGA 2002 referred to central and local government as "two arms of our system of government with a shared focus on contributing positively to the well-being of communities". The reasoning behind this view highlighted the need for collaborative government:

The social, economic and environmental problems confronting New Zealand are not capable of being solved by central government alone. ... The legislation needs to give local government sufficient scope for it to be able to work in partnership with central government, and with community and business ... (DIA 2000, p. 3).

The nature of the social, economic and environmental problems that would need local government's help to solve was not explained, or a commitment made to sharing resources. The Government's initial policy document introduced the notion that local authorities should play a role as community leaders, brokers and facilitators and was notable for declaring that "there is no intention on the part of the government to withdraw from areas for which central government is currently responsible, by passing over responsibility to local government" (DIA 2000, p. 8).

Despite the rhetoric, there was a dearth of practical measures by which any partnership might be given effect. The British government, in contrast, introduced a number of statutory vehicles to give effect to their new focus on joined-up government, such as Local Strategic Partnerships (LSPs) and Local Area Agreements (LAAs). As mechanisms for horizontal co-ordination involving public and non-public agencies operating in localities, LSPs brought together agencies into an overarching local institution operating within a multi-level 
governance framework. Decisions to establish LSPs are local decisions but they are mandatory for any local authority wishing to access certain national funding streams, particularly regeneration funding (Geddes 2005). LAAs, which bind agencies to achieve a set of common objectives and may involve joint budget holding, are another mechanism for negotiating priorities between central and local government and allow departments to better understand the local context faced by councils and their partners. While LAAs have a binding effect on participating agencies, the choice of whether or not to participate is voluntary. At least part of the Government's intention in introducing LAAs was to "devolve decision-making, move away from a Whitehall knows best philosophy and reduce bureaucracy" (Local Government Chronicle, 5 June 2008, p. 18). The result is a form of meta-governance designed to deal with a "jungle of organisations and institutions" (Geddes 2006, p. 6).

In New Zealand, examples of intergovernmental collaboration were in place well before the LGA 2002 gave it principled support. A particularly successful example was a monthly forum of departmental heads in the South Auckland area, which was convened by the chief executive of Manukau City Council. Their regular discussions enabled the various agencies to better co-ordinate programmes and address gaps and service overlaps. Another initiative was the Strengthening Families initiative, in which mayors were asked to play a coordinating role with local social service agencies.

The LGA 2002 gave these sorts of initiatives its moral blessing and, as noted in Chapter 1, the Government worked to improve relationships between departments and councils, particularly in relation to the community outcomes process. Yet it failed to take the next step, unlike the government of the United Kingdom, which was to provide collaborations with some form of legislative status. It stopped short of introducing any equivalent mechanism to the LAA, for example, despite its high level principles emphasising the need to work collaboratively. The New Zealand public sector continues to be vertically oriented with accountability cascading down from ministers to 'on the ground' departments. It is a model that makes it difficult to establish more horizontal and resource-sharing place-based approaches to public services. 


\section{Dimension assessment}

This dimension looked specifically at the existence or otherwise of formal mechanisms for establishing joint central-local government initiatives, noting that a number of successful ad hoc collaborations exist but that the legislative architecture was relatively silent on such relationships. Other than formal agreements, such as memoranda of understanding or contracts for service, the legislative framework lacks any vehicle to enable joined-up governance to occur in a comprehensive manner. This dimension is assessed as showing room for improvement.

\section{Decision-making}

This indicator is concerned with the degree to which citizens are able to influence local government decision-making outside the triennial election process. The measure concerns the existence or otherwise of statutory mechanisms that allow/encourage such influencing.

Theoretical models of decision-making range from political, in which elected representatives make decisions based on their political intuition, to technocratic, in which decisions accord to explicitly stated values and are weighted according to impact. They also vary according to the degree to which decisions are made by representatives or by a broader range of actors, reflecting a more participatory style. Any discussion might also consider the institutional setting and whether or not it privileges political or policy considerations in the decisionmaking process. Similar issues exist with regard to inclusiveness and the participation of elites, including how well the decision and policy-making frameworks provide for a contest of ideas.

Theories of community governance value high levels of citizen participation. For example, the Swiss approach, echoed by many local governments in the United States, enables citizens to use referenda to direct their local authorities or to halt an unpopular decision. Referenda act both as a method for signalling community preferences and as a check and balance on the exercise of local 
power, particularly in systems with a history of low voter participation like the United States. Referenda can also be non-binding, in which cases they are used to signal community preferences. ${ }^{85}$ More deliberative approaches are typified by the use of focus groups, citizen juries and participatory budgeting. Strategies to enhance citizen involvement in decision-making may also focus on encouraging participation by marginalised and under-represented groups in order to increase voice, particularly migrant communities and indigenous peoples. Typical mechanisms involve the use of advisory boards, agreements with civic organisations representing particular sectors, and co-opting community representatives to decision-making bodies.

The objective of involving citizens in the decision-making process is to ensure local authority services meet the preferences of local citizens. Without this, utility might be lost by over- or under-provision. Hirschman's concept of exit and voice (see Bailey 1999) provides a framework to explain how influence occurs in different institutional environments. Exit is concerned with the ability of a consumer to shift between different suppliers of a similar product and in a local government context it suggests that citizens will leave a local government jurisdiction if the service quality deteriorates or the cost increases beyond their willingness to pay. Exit is an important (even virtual) constraint on the behaviour of local government politicians and managers as any loss of population translates directly into a loss of income and status. Voice, in contrast, is the way in which citizens inform the managers of businesses about their concerns regarding the quality or nature of services. In the political context, voice involves an individual or collective appeal to political representatives to change or protect a policy or programme. The mechanisms through which voice is expressed include voting, petitions, submissions, and direct representation to elected representatives. Local government, with its proximity to service users, is more favourable to the success of voice strategies than higher level governments. Voice has advantages over exit as the conditions for making exit a realistic

\footnotetext{
${ }^{85}$ The New Zealand framework allows citizens to demand a referendum in relation to a narrow range of matters, such as the choice of electoral system and Maori wards. It also gives councils discretion and as a result the use of referenda has been slowly growing. Whanganui District Council, for example, holds annual referenda to identify wish list items for annual council expenditure.
} 
choice are almost impossible in practice (see the discussion on Tiebout in Chapter 4).

The decision-making model in New Zealand local government has a strong rational-comprehensive character, which has increased progressively since 1989. Much of it involves highly prescribed processes and, while arguably contributing to more consistent policy decisions, has cramped the decisionmaking space of local politicians. ${ }^{86}$ In tandem with the consequential diminution of the decision-making realm historically undertaken by elected representatives (also diminished through the establishment of arm's-length organisations to undertake trading activities), local government reformers have also attempted to increase the role of citizens in the decision-making process. The mechanism for achieving this has primarily involved mandatory consultation for certain kinds of decisions, especially those concerned with the annual budget and work plan as well as matters of significance, for example, decisions to sell strategic assets. It has also involved the establishment of sub-municipal authorities, community boards that were established to bring local governments closer to their communities and give greater opportunities for citizens to influence decisions.

Consultation can be understood as a form of voice and, along with voting, it is one of the primary mechanisms by which citizens influence the behaviour of their elected representatives in the New Zealand model. Consultation was a critical part of the local government framework introduced by the LGA Amendment (No. 3) 1989 and within a relatively short period of time a judicial interpretation of consultation emerged (see Wellington International Airport v Air New Zealand [1993] 1 NZLR 671) which formed the basis for the introduction of consultation principles in the LGA 2002. These principles require councils to provide people affected by a council decision with relevant information, encourage such persons to present their views in a manner which is appropriate to them and consider the views of such parties with an open mind (s82 LGA 2002). Councils also have some discretion about the level to which they comply with these principles, the level of compliance being proportional to the level of

\footnotetext{
${ }^{86}$ The Office of the Auditor-General's Guide to Decision-Making (www.oag.govt.nz) lists seven principles which must be considered in any decision-making process.
} 
significance of the issue(s) under consideration. In essence, decision-makers were required to be seen to have listened to community views and approached the decision-making process with an open (although not blank) mind.

In the local government framework introduced in 2002, Parliament has essentially sought to 'second guess' the political judgement of councillors in two critical ways. The first is through the requirement to adopt significance policies (s90, LGA 2002); these detail how significance will be defined for the purpose of consultation (the majority of councils use a financial threshold) as well as establishing a set of consultation principles (s82, LGA 2002). The second was the decision to make consultation on certain kinds of issues mandatory, and going as far as to detail the type of consultation that should be undertaken, for example, adopting annual and long-term plans as well as decisions that might affect the ownership of 'strategic assets' ${ }^{87}$ The particular process to be followed is defined in the legislation as the Special Consultative Procedure (SCP) (see Chapter 1).

Whether or not mandatory consultation has increased citizen influence on council decision-making is a matter that is strongly contested. The consultation provisions in particular have come in for ongoing criticism, with claims that few people make use of the opportunity (thus it is an expensive waste of time) and that those who do take the time and trouble reflect a minority of the community - the squeaky wheel syndrome. And the Government's attitude has changed significantly since the 2008 elections, with the new Minister of Local Government, the Hon. Rodney Hide, promising to reduce the compliance costs caused by consultation, particularly the newer provisions the LGA 2002 had placed on councils (Illuminating Local Government, Hon. Rodney Hide, 21/October 2009, www.beehive.govt.nz).

Similarly the Inquiry into Local Government Rates (2007) noted that "the consultation processes on LTCCPs is widely regarded as being inadequate and

\footnotetext{
${ }^{87}$ In addition to a small number of identified activities, for example, social housing stock, a strategic asset is any asset the council resolves to be a strategic asset.
} 
many councils approached the process with predetermined views" (ibid, p. 253), and recommended that councils should make more use of a broader range of mechanisms to obtain community views, such as focus groups. The Local Government Commission's Review of the LGA 2002 and LEA 2001 (Local Government Commission 2008) also addressed the quality of consultation and undertook a national survey of individuals who had made submissions to a local authority. In response to the question 'How would you rate the public consultation process?' 30 per cent of respondents said excellent or very good and another 29 per cent said the process was good (ibid, p.70). The proportion of respondents rating the process as poor was 21 per cent. Notably, 95 per cent said they would likely make another submission. The Local Government Commission recommended that additional good practice guidance be prepared for councils and that the effectiveness of council consultation procedures is monitored.

Views on consultation practice tend, however, to be quite variable, possibly reflecting local or regional experience. Submissions received by the Royal Commission into Auckland Governance when undertaking their public consultation process on the future shape of Auckland documented considerable citizen disenchantment with existing council decision-making processes, particularly in relation to Auckland City itself:

In the commission's opinion, while there may be a need for changes in the way councils consult, and the matters on which councils choose to consult, there is a wider need for councils to engage with their public in other ways. The evidence of dissatisfaction about consultation suggests a need to reassess the balance between public participation and consultation on the one hand, and efficiency, effectiveness and responsiveness on the other (Royal Commission on Auckland Governance 2009, p. 298).

Despite these concerns, the numbers of submissions councils have received when undertaking the special consultative procedure to adopt annual plans and the triennial LTCCP have grown substantially (see Table 34) and, since the 
passage of the LGA 2002, improved in quality. ${ }^{88}$ Research undertaken by researchers from Massey University into the character of submitters and their feelings about the process found that regardless of whether or not they were successful in changing their council's attitude submitters valued the process enough to indicate a willingness to participate in the future (Forgie 2002).

Table 34 Average number of submissions received by councils

\begin{tabular}{|l|l|}
\hline Year & Submissions \\
\hline $1991 / 92$ & 67 \\
\hline $1994 / 95$ & 160 \\
\hline $1999 / 00$ & 341 \\
\hline $2002 / 03$ & 424 \\
\hline $2006 / 07^{89}$ & 507 \\
\hline $2009 / 10$ & 951 \\
\hline
\end{tabular}

(Source: unpublished surveys undertaken by Local Government New Zealand and the Society of Local Government Managers)

Within the local government legislative framework, consultation provides an important mechanism by which citizens can ensure their views are heard by decision-makers and one which New Zealand citizens continue to hold in high regard. However, questions exist about the inclusiveness of the process, particularly the SCP, with some critics suggesting the statutory provisions for decision-making are "excessively detailed, complex, and potentially confusing for the various parties involved" (New Zealand Government 2007, p. 247). Questions have also been raised about the representativeness of the individuals and groups who make use of the opportunity afforded by the SCP (ibid). The decision by the High Court to overturn Christchurch City Council's decision to raise social housing rents (Council of Social Services in Christchurch/Outautahi Incorporated v Christchurch City Council, CIV-2008409-001383, 25 November 2008) was, however, significant. One of the grounds

\footnotetext{
${ }^{88}$ Private discussion with Mary Bourke, former Mayor of South Taranaki, who noted that the LTCCP had raised the quality of community submissions.

${ }^{89}$ Years 2006/07 and 2009/10 are for submissions on the triennial LTCCP. Both figures represent a sample of 60 councils.
} 
on which the decision was overturned was the council's failure to consult properly with the affected parties (the tenants) and it highlights the potential degree of citizen power in relation to the way their councils make decisions and set policy.

However, other institutional factors are potentially diminishing this level of influence. One is the gradual reduction in the number of elected members and the other concerns changes to the institutional structures by which councils make decisions. The ratio between citizens and their elected members is regarded as important for the purpose of access - the smaller the ratio the greater proximity between representatives and citizens and consequently the greater the access for influencing decisions (Drage 2008). Since 1989 there has been a growth in representation ratios as population increases have been accompanied by a reduction in the number of elected members (see Table 35). This issue is discussed in more depth in the next section of this chapter. ${ }^{90}$

Table $35 \quad$ Number of elected members

\begin{tabular}{|c|c|c|c|c|}
\hline $\mathbf{1 9 9 2}$ & $\mathbf{1 9 9 5}$ & $\mathbf{1 9 9 8}$ & $\mathbf{2 0 0 1}$ & $\mathbf{2 0 0 4}$ \\
\hline 1,082 & 1,054 & 1,024 & 995 & 936 \\
\hline
\end{tabular}

(Source: www.lgc.govt.nz)

Historically, decision-making in councils involved a mix of delegated authority, exercised by standing committees and officials, and decisions made by the 'committee of the whole', the council. Under conventional practice, policy issues would be raised for the first time at a standing committee meeting, options would be discussed and decisions were either made or recommendations sent to a meeting of the whole (the full council). Committee meetings tend to be less formal than full council meetings and enable interested members of the community, citizens and organisations to engage with councillors as they consider policy options. Standing committees provide an opportunity for citizens to place matters on the council agendas and ensure councillors, as decision-

\footnotetext{
${ }^{90}$ If the government goes ahead with its plan to consolidate the councils of Auckland this figure will decline.
} 
makers, receive access to a broader range of advice than what they would normally receive from their professional advisers.

Following the LGA 2002, a trend developed in which many councils disbanded their standing committees and conducted all or most of their business directly through the committee of the whole, the full council. In many cases individual councillors were given specific policy portfolios, for example regulations, recreation or transport, and were expected to work directly with the appropriate council officer to bring recommendations directly to the council table. The advantages of this approach are seen to be its efficiency, the speed of decisionmaking and the ability to be strategic, that is, to keep the council's attention focused on a specific goal or objective. In some cases the reduction in councillor numbers - some councils have only six councillors - meant that committees in the traditional style were not even possible. ${ }^{91}$ From a community governance perspective, however, the down-side has been to limit the ability of citizens to talk directly to councillors in a decision-making process, reduce the amount of time taken to fully discuss issues, limit debate by increasing the ability of officials to effectively control the policy agenda, and reduce transparency. This is also influenced by the actual number of councillors in each local authority. In comparison with international norms, New Zealand councils are among the smallest (see Figure 12). Ultimately the emerging institutional forms with regard to representation have important implications for the degree to which alternative voices are able to influence the policy process and how well policy consistency is likely to be achieved.

\footnotetext{
${ }^{91}$ Under the LGA 2002, territorial authorities must have between six and 30 councillors, including the mayor. Auckland City Council is the only council with more than 20.
} 
Figure 12 Number of councillors by council

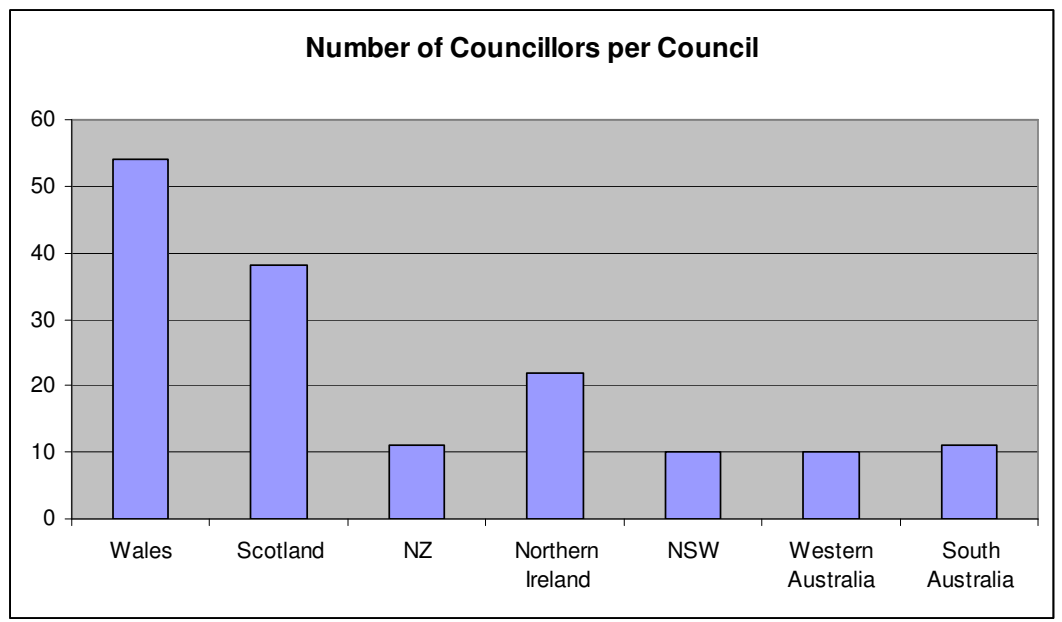

(Source: data drawn from country local government association websites)

\section{Dimension assessment}

In relation to public participation in decision-making, the New Zealand model is finely balanced, with the legislative framework providing a broad range of opportunities for citizens to influence decision-making while still allowing considerable discretion as to how this might be applied 'on the ground'. However, faced with declining rates of political representation and an increase in more 'corporate' style of decision-making practices, this dimension is assessed as having room for improvement. ${ }^{92}$

\section{Local democracy}

Perhaps the most important component of a bottom-up accountability framework, which underpins the community governance literature, concerns the electoral process and the degree to which it provides local voters with 'tools' to change the composition of their councils and their direction. The evidence in relation to local government in New Zealand is mixed. This dimension is concerned with what might be described as the 'thickness' of New Zealand's local democratic institutions, thickness being a reflection of the level of representation and the opportunity for citizens to influence and change their

\footnotetext{
${ }^{92}$ As an example, a number of councils made media headlines in 2008 for their decisions to suspend the right of citizens to make presentations directly to councils prior to the start of their regular council meetings, namely Whangarei District Council and Dunedin City Council.
} 
representatives. This dimension employs two measures: voter turnout and representation ratio.

Voter turnout is likely to be a headline indicator in any discussion of a system's democratic health and is frequently used to judge the legitimacy of political representation. Turnout in New Zealand council elections has been falling since 2001 (see Figure 13), resulting in considerable public concern and discussion. Concern was such that select committee inquiries were held into the running of the local government elections following the 2001, 2004 and 2007 elections the last two inquiries recommending a number of largely technical changes to electoral processes and timetables.

Figure 13 Average voter turnout 1989-2007

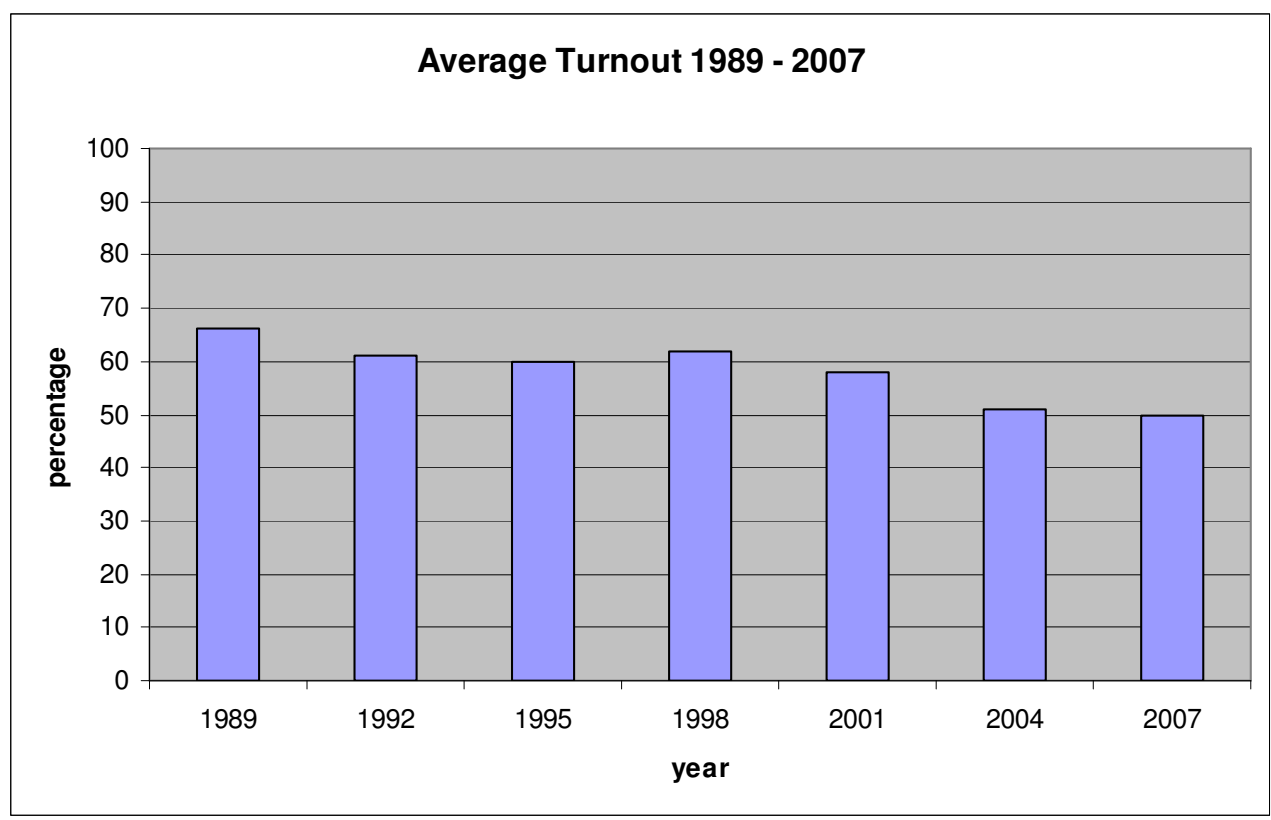

(Source: compiled from data sourced from www.lgc.govt.nz)

Despite the views of officials and media commentators about lack of interest in local democracy, turnout rates are complex. While total turnout in local government elections has declined, the average turnout per council continues to sit at around 50 per cent, noticeably higher than experienced by similar local government jurisdictions, for example South Australia. However, the average figures hide a wide diversity of turnout rates, with the rates for the ten largest 
cities sitting between 35 per cent and 40 per cent, significantly below turnout for rural and provincial centres. ${ }^{93}$

Local government's electoral arrangements are governed by explicit legislative requirements and the process of meeting those requirements is overseen by an independent body, the Local Government Commission. The Local Government Commission is relatively unique and consists of three commissioners appointed by the Government. The Commission was established in the 1940s with the intention of facilitating the consolidation of local government numbers, a task that took more than 40 years to accomplish. It was also given responsibility for hearing and ruling on objections and appeals to the representation reviews that councils must carry out at least once every six years to ensure their representation arrangements conform to the relevant statutes. In all cases the commission plays the role of independent arbiter with the right to make binding decisions. It is a role that contributes to public confidence by ensuring that electoral arrangements are fair and practices that might privilege particular groups of voters, such as the practice of redistricting, are prevented.

When considered in an international context New Zealand's local government turnout rate sits below the average of turnout rates in developed countries (see Table 36), although it is relatively consistent with rates in countries with AngloAmerican type local authorities (see Chapter 4).

Table $36 \quad$ Local government voter turnout (post 1995)

\begin{tabular}{|l|l|}
\hline Jurisdiction & Turnout \% \\
\hline Denmark & 72 \\
\hline Netherlands & 47 \\
\hline Germany & 70 \\
\hline United Kingdom & 35 \\
\hline South Australia & 32 \\
\hline British Columbia & 30.7 \\
\hline
\end{tabular}

\footnotetext{
${ }^{93}$ More than half the drop in turnout in 2007 can be explained by a fall in the turnout rate for Auckland City, where the mayoral race was fought by the same two candidates who contested it in 2004.
} 


\begin{tabular}{|l|l|}
\hline Ireland & 50 \\
\hline Western Australia & 34 \\
\hline New Zealand & 49.7 \\
\hline
\end{tabular}

(Adapted from Kleinman et al 2002, p. 21)

There are a range of problems in trying to compare turnout rates in different local government jurisdictions. For a start, not all local government systems provide the same services. Turnout is higher, for example, in the Nordic systems, where councils provide a wide range of social welfare functions in a decentralised environment. These countries appear in italics in Table 36. In addition, the number of elected positions differs significantly (see below) and there is some evidence to suggest that turnout has a positive correlation with lower representation ratios (Drage 2008). Also the 'mechanics' of local electoral systems differ, in relation, for example, to the use of wards or 'at large' systems or between booth and postal voting. Another factor is the degree to which council elections are held in isolation or are packaged with elections for other bodies, particularly higher level governments.

There is a considerable degree of correlation in the turnout rates of Anglophile countries, such as New Zealand, Canada, Australia and Ireland. All tend to have minimalist forms of local government and much lower turnout levels. The United Kingdom itself is an interesting case as local government there undertakes a broader range of functions than the other Anglophile countries but in practice is largely an agent for government departments and councils have limited discretion over spending - possibly the cause of their poor levels of voter turnout.

While turnout in New Zealand council elections increased markedly in 1989 as a result of amalgamation and the almost universal the shift to postal voting, ${ }^{94}$ from 2001 onwards elections were expanded to include elections for District Health Boards. Three years later, in the 2004 elections, the 22 health boards also

${ }^{94}$ The last council to use booth voting was Hutt City in 1992. 
changed to the Single Transferable Voting System (STV), which meant that voters were not only faced with a considerable number of candidates from which to choose but had to use two separate voting systems, STV for health boards and First Past the Post (FPP) for most councils. In fact the decline in voter turnout in 2001, 2004 and to a lesser degree 2007 is partly being credited as being caused by the complexity that resulted from such incremental changes (see the Report of the Justice and Electoral Select Committee, House of Representatives 2005). In summary, voter turnout statistics in New Zealand local government paint a mixed picture. Turnout rates for district councils and in particular rural councils are more than acceptable for this type of local government system; however, turnout rates of less than 40 per cent in the large cities result in some elected representatives who have relatively small mandates.

The representation ratio is the number of elected positions in relation to the number of citizens in any jurisdiction and is perhaps the most important contributor to the concept of democratic thickness. The number of citizens each councillor represents bears directly on her or his ability to be responsive to individual and neigbourhood concerns as well as having a positive correlation with the willingness of citizens to vote (Drage 2008). In comparison with international norms, New Zealand representation ratios at the local level are high (see Table 37 ) and recent trends suggest that this ratio is increasing.

Table 37 International representation ratios

\begin{tabular}{|c|c|}
\hline Country & Ratio \\
\hline France & $1: 120$ \\
\hline Germany & $1: 250$ \\
\hline United Kingdom & $1: 2,600$ \\
\hline New Zealand & $1: 4,647$ \\
\hline Scotland & $1: 4,229$ \\
\hline Wales & $1: 2,376$ \\
\hline NSW & $1: 3,942$ \\
\hline South Australia & $1: 2,088$ \\
\hline
\end{tabular}


(Source: Local Government Centre, Auckland University of Technology, Briefing to the Incoming Minister, November 2008)

New Zealand's representation ratio is not only high by international standards, it is also increasing. Table 37 highlights the effect of the consolidation of councils in 1989 and subsequent representation reviews undertaken by councils and the Local Government Commission. While allowing for the significant reduction caused by consolidation, there has also been a steady reduction in the number of councillors, a trend that was accelerated between 2001 and 2004.

Representation ratios are highest in the largest cities and in the regional councils and as regional councils find their role expanding, the high representation ratio may become a matter of concern. ${ }^{95}$ An example of a growing tension caused by perceived representation issues is the attempt by territorial authorities in South Canterbury to establish a break-away regional council in response to concerns that their part of the region is underrepresented in Environment Canterbury. ${ }^{96}$

Decisions about numbers of councillors are taken by individual councils prior to elections or are made by the Local Government Commission, should it be considering either in an appeal or objection to a council's draft representation scheme. The reduction in the total number of councillors (territorial councils may have between six and 30 councillors, with the average being 11) suggests a view of councils which sees them akin to a board of directors and has led to higher representation ratios (see Table 38).

Table 38 Representation ratio in New Zealand local government

\begin{tabular}{|l|l|l|l|l|}
\hline Council type & $\mathbf{1 9 8 3}$ & $\mathbf{1 9 9 2}$ & $\mathbf{2 0 0 1}$ & $\mathbf{2 0 0 4}$ \\
\hline Regional & 15,301 & 16,786 & 18,543 & 18,993 \\
\hline City & 4,467 & 4,818 & 6,622 & 7,570 \\
\hline District & 597 & 1,328 & 1,696 & 1,831 \\
\hline
\end{tabular}

(Source: Drage 2008, p. 10)

\footnotetext{
${ }^{95}$ For example, the Land Transport Reform Bill 2008 required the establishment of regional land transport committees to develop priorities for the allocation of road and transport funds.

${ }^{96}$ See Stoush in the South, 1/1/2009 at www.stuff.co.nz/the-press/lifestyle/mainlander/150421.
} 
Reducing the number of politicians and consequently increasing the representation ratio also impacts on the ability of councils to reflect the diversity of their particular communities (fewer positions therefore less ability for minority groups to get around the table) and potentially limits the ability of representatives to steer management. Smaller councils are less likely to contain diverse options and more likely to be subject to management capture. The question of a council's ability to govern in the public interest, as these issues highlight, has led some lobby groups to argue that additional mechanisms are needed to ensure councils act in accordance with the views of their citizens. For example, the New Zealand Business Roundtable, a body which represents a number of the country's major businesses, possibly spoke for a wider audience when it suggested "councils might be enabled to go beyond core public good services (only) if they obtained consent from their ratepayers through referenda" (Council Democracy and Performance Must Be Improved, Roger Kerr, Executive Director, New Zealand Business Roundtable, The Dominion Post, 19 July 2010). The Roundtable's 'problem' sums up one of the overriding themes since the reform and modernisation of local government in New Zealand since 1989 , namely the challenge of creating responsive local governments able to advance the local public interest while also ensuring the interests of specific communities, such as business, Maori and the elderly, are not diminished.

The final aspect of this measure is whether or not the voting system itself is conducive to strong community governance. Milner (2002) argues that proportional voting systems outperform majoritarian systems in the quality of representation. New Zealand local elections have historically been run on a First Past the Post (FPP) system; however, since 2001 councils and citizens were given the choice of electoral systems between FPP and the Single Transferable Vote system (STV). Eleven councils either voluntarily, or forced by community referenda, adopted STV for the 2004 elections. Three years later the number of councils using STV had fallen to eight and only six will be using the system in 2010. The existence of STV, a system that is promoted on its ability to ensure the results of elections reflect the preferences of voters, strengthens the local democratic framework; however, the failure of the Government to promote the system and the small take-up rate has diminished its impact. 


\section{Dimension assessment}

The measures that constitute democratic thickness are mixed. New Zealand scores poorly with regard to representation ratios, is perhaps middling with regard to voter turnout and scores well with regard to the transparency of its electoral processes. However, the predominance of FPP as the voting system represents a negative factor. This dimension is assessed as showing room for improvement.

\section{Analysis}

The overall purpose of the assessment model is to assess the capacity of the current framework of local government in New Zealand to adopt a community governance approach. It does this by disaggregating the system into dimensions and assessing each dimension against a range of criteria. Most of the dimensions represent the necessary conditions for community governance to occur in the sense that they need to be in place if a council is to exercise community governance, while others, such as strategy and leadership, represent sufficient conditions. A summary of the dimensions and their rankings is provided in Table 39.

Table 39 Summary of assessment

\begin{tabular}{|l|l|l|}
\hline \multicolumn{1}{|c|}{ Principles } & \multicolumn{1}{|c|}{ Dimensions } & \multicolumn{1}{c|}{ Ranking } \\
\hline Authority & & \\
\hline & Size and structure & Room for improvement \\
\hline Autonomy & Finance & Adequate \\
\hline & Empowerment & Adequate \\
\hline outcomes & Supervision & Adequate \\
\hline & & \\
\hline Community focus & & Room for improvement \\
\hline & Strategy & Room for improvement \\
\hline
\end{tabular}




\begin{tabular}{|l|l|l|}
\hline & Leadership & Room for improvement \\
\hline Partnership & & \\
\hline & Collaboration & Room for improvement \\
\hline Inclusiveness & & \\
\hline & Decision-making & Room for improvement \\
\hline & Local democracy & Room for improvement \\
\hline
\end{tabular}

The assessment highlighted the following features for each of the six principles:

- Authority: councils' ability to raise and allocate resources to address local priorities was assessed positively, as was the general size and capacity of councils. The only qualifier to this assessment is the relatively large 'tail' of small councils, which raises questions about capacity as well as the relatively 'diminished' role of many regional councils in relation to community governance. The lack of an effective multi-level system of governance was seen to reduce opportunities for central government to devolve further responsibilities to the sub-national level.

- Autonomy: the manner in which councils are empowered and the supervision approach used by central government both act to provide councils with sufficient autonomy to undertake effective community governance.

- Outcomes orientation: in relation to functions the New Zealand system is at the minimalist end of the spectrum, although councils do have the flexibility to 'top up' or deliver services which complement those provided by central government. Consequently the assessment is 'room for improvement'.

- Community focus: strategy and leadership dimensions were also assessed as showing room for improvement, even though the LGA 2002 introduced a requirement to identify community outcomes. This assessment reflects the lack of any formal requirements for central government agencies to participate in the outcomes process. The assessment of the leadership dimension, 'room for improvement', 
reflected the failure of the LGA 2002 to address the issue of community leadership, particularly in comparison with other jurisdictions.

- Partnership: although collaboration is included in the LGA 2002 as a principle, this dimension has been assessed as having room for improvement due to the lack of formal mechanisms, such as LAAs, to enable effective central-local government collaboration at the local level.

- Inclusiveness: while decision-making and democracy highlighted both strengths and weaknesses, it was the declining level of representation and dominance of FPP that led to the assessment of 'room for improvement'.

The overall results of the assessment suggest that initiatives to strengthen community governance need to address a broad range of issues, such as the current limited role given to regional councils; the overall range of functions undertaken by the local government sector as a whole; the lack of any mandatory obligations on government agencies to collaborate; and limitations in existing mechanisms for encouraging inclusiveness.

\section{Conclusion}

This chapter has examined local government in New Zealand against a range of measures in order to assess the ability of the system to achieve community governance. The community governance assessment model found that in terms of the authority and autonomy principles the New Zealand system was relatively well placed. The major down-sides were the tail of small councils and the underdeveloped nature of regional government. The principles that had the poorest assessment, and thus reflected areas which need to be strengthened the most, were outcomes orientation, community focus, and partnership. In particular, the dimension of community planning needs refinement; there is room for greater devolution and local leadership is generally not well recognised.

On the basis of these assessments, Leonard and Memon's (2008) view that the New Zealand system represents community governance in action is somewhat optimistic. There is certainly evidence that community governance theory has 
influenced the LGA 2002 - both its design and the language that accompanied the review. Yet, ultimately, the LGA 2002 left the fundamental relationship between councils, the state and citizens relatively untouched, creating substantial room for further change if community governance is to be achieved. Particular options that might address areas where improvements might be made are outlined in the next, concluding, chapter. 


\section{Chapter 8 Pathways to stronger community governance}

This chapter summarises the research findings and proposes options for strengthening the ability of the New Zealand system to adopt a community governance approach. Areas for further research are identified.

Governance, in its very broadest sense, is about how members of a society make decisions about their collective welfare. Effective governance reconciles national and local interests by providing institutions and processes for citizens and their representatives to make decisions affecting their localities, in a context of nationally negotiated values and priorities. The community governance literature is largely a normative literature that encourages local authorities to take an active interest in all issues affecting their localities (including those which are outside their administrative responsibilities) in an effort to achieve desired local outcomes. It is inherently suspicious of 'top-down' designed policy solutions, which it sees as undermining local democracy and citizen initiative. Local government is seen to play a critical role in this process as it provides the democratic legitimacy that allows citizens to make choices about the nature of their communities. This view of local government can be understood as a desire to rebalance political life by shifting authority from the centre towards the periphery. Local government as community governance also challenges the more traditional functionalist approach to local government, which defines councils primarily as service providers.

There is, however, no universal template for the optimal distribution of decisionmaking between spheres of government, as institutional development reflects the social and historical context of each country as well as the heterogeneity of society's political institutions and the actions of particular political actors. The result is a patchwork quilt of local and national governance models, with patterns of similarity, overlap and difference that make it difficult to compare different local government systems, but some dominant trends can be observed. Most countries in the developed world have modernised their local 
governments in pursuit of transparency, accountability and clarity in the relationship between politics and administration. Devolution has been a popular reform strategy in many countries (see Naschold 1997), as has the expansion of opportunities for citizen participation; but these reforms have proved to be the least successful. More recently, for example, in the United Kingdom, Norway and New Zealand, there has been a focus on integrating local and national governance and strengthening local government's role in community governance, although the process is far from linear. The New Zealand example is a case in point. While this study has noted that community governance has been strengthened since 1989 it has also observed that some measures have had an undermining effect. Local government reform in New Zealand has been incremental, rather than purposeful; and Parliament seems to have developed an appetite for reforming the sector in an ad hoc manner, so more change is highly likely.

\section{Research findings}

The primary research question is concerned with how to strengthen local government and local governance in New Zealand. In order to evaluate the existing system of local government to identify areas for improvement, the following community governance principles were adopted:

1. Authority: councils exercising community governance have sufficient authority to make decisions on matters of local public interest.

2. Autonomy: councils exercising community governance can respond to citizens' concerns without undue restrictions imposed by higher authorities.

3. Outcome orientation: councils exercising community governance are concerned with broad intersectoral outcomes of concern to their citizens.

4. Community focus: councils exercising community governance involve citizens and stakeholders when determining priorities and the community's long-term direction. 
5. Partnership: councils exercising community governance undertake policy and operational co-ordination with other organisations including other levels of government.

6. Inclusiveness: councils exercising community governance implement mechanisms to allow citizens to participate in decision-making.

The analysis of the New Zealand system highlighted the influence of community governance ideas, particularly in the design of the LGA 2002. It also revealed that many of the concepts incorporated into that legislation were far from compatible with each other. Any review of local government provides opportunities for agencies to push their own agendas and the LGA 2002 was no exception. While it was enshrined in many of the principles of the legislation, community governance was not pursued comprehensively. In particular, the LGA 2002 left the constitutional position of local government unchanged and failed to address the fundamental imbalance in the central-local government relationship.

The case studies of councils undertaking the community outcome component of their LTCCPs examined whether councils used the process to try and take a community governance approach and whether horizontal alignment and coordination were being achieved. Some councils appeared to place considerable emphasis on strategies to strengthen collaboration with other agencies, both statutory and community based, which resonated strongly with the community governance narrative, particularly Manukau, Waitakere and Porirua Cities, but they were not widely replicated. For some councils, particularly the smaller ones, community planning was largely a matter of compliance; the larger cities were more successful at exploiting the framework, particularly regarding the alignment of local and national priorities. However, in many ways their success had more to do with the attitude of the Government and its agencies than any specific mandate provided by the LGA 2002. The involvement of central government agencies was ultimately contingent on the preferences of individual officials or/and ministers, although there were efforts by some departments, such as the Department of Internal Affairs, to encourage engagement. 
The research sought feedback on several governance scenarios. The responses were mixed, suggesting that each scenario had strengths and weaknesses, and involved difficult trade-offs. For example, while larger authorities were favoured for their greater capacity, concern was expressed at the diminished voice of their citizens. Participants supported more integration between local and central government but expressed concern about loss of autonomy and the risk of bureaucratic capture. Finally, localist models were supported but concerns were registered about lack of capacity and the need for economies of scale. In summary, there was perceived to be no perfect recipe. Ideally, governance systems should combine responsiveness to citizens' concerns with economies of scale and capacity. Aligning services with higher level governments is important to achieve local aspirations, but somewhere a balance is needed to preserve local autonomy. It is argued that the failure of the New Zealand local government system to reconcile these purposes explains the lack of any systematic programme of devolution, particularly of social policy functions, a common frustration expressed by social reformers throughout the 20th century.

The assessment model was used to examine dimensions of the New Zealand system of local government to assess how well situated they were to implement a community governance approach. The research found that, compared with many systems of local government, the New Zealand model scored well on the authority and autonomy principles, which are concerned with freedom of action and popular mandate. Despite the lack of constitutional recognition, councils have a freedom of action that many other systems of local government still aspire to. The assessment was less positive in relation to the outcomes orientation and leadership principles, which are concerned with the capacity of councils to influence outcomes and steer the numerous organisations and agencies that contribute to their achievement. The New Zealand model was also seen as having room for improvement in relation to its minimal functional responsibilities and the lack of an effective mechanism to require other agencies, especially central government agencies, to participate in its community planning initiatives. Similarly, the New Zealand model showed room for improvement in relation to the partnership principle because of the lack of 
effective statutory vehicles for inter-agency collaboration. Weaknesses were also found regarding the inclusiveness principle because of the growing representation ratio and the increasingly technical decision-making processes.

While the strengthening community governance was arguably never an explicit goal of the 2002 local government reforms, many of the measures introduced in the LGA 2002 had that effect. Reform did not occur in a vacuum and much of the reform rhetoric owes much to the language that surrounded New Labour's local government agenda in the UK. Not surprisingly the effect on the final legislation was always going to be partial. For example, requiring councils to facilitate a process so that communities could identify and prioritise their desired outcomes can be seen as an important acknowledgement of community governance; however, the failure to require government departments and agencies to take part in the process or 'buy in' to the outcomes suggested a task half done, particularly since most community outcomes addressed issues that were the principal domain of the centre. Although the provisions of the LGA 2002 reflected many of the community governance themes in the academic and international literature, the result has been somewhat disappointing. Public sector reform has struggled to shift from its initial focus on vertical accountability and nationally determined targets, leaving departments with little discretion to consider local needs, although some exceptions need to be noted. Councils that believed facilitating community conversations to determine locally-desired outcomes would be a first step towards stronger action by the centre to address local concerns and achieve outcomes were generally, though not invariably, disappointed. Ultimately there was a lack of institutional reorientation, particularly by central government. This is unsurprising, since community governance was never an explicit objective of the LGA 2002; and its focus on accountability and transparency, which has been a major theme since 1989, continued to be a strong driver. Local government policy tends to be undertaken by parts of government with relatively little influence on overall government direction, so significant changes may not be reflected elsewhere in the bureaucracy - ironically, the concept of community governance arose in response to fragmentation and silos and they remain one of the main obstacles to its successful introduction. 


\section{Options for strengthening community governance}

The research found several areas where local government in New Zealand was under-performing regarding its ability to implement community governance. Room for improvement was identified in seven of the dimensions examined: size and structure; functions; strategy; leadership; collaboration; decisionmaking; and local democracy. It is noteworthy that many of these were identified as issues in the policy papers prepared as part of the 2002 reforms and they remain unresolved. International practice can be used to strengthen performance in those dimensions.

\section{Structure and function}

The New Zealand system was assessed poorly in the functions dimension, with councils performing what can be considered to be a minimal range of functions. It was assessed similarly in the size and structure dimension, with the lack of an effective model of multi-level governance being assessed by the author as a limiting factor for the purpose of achieving community governance. The two issues are related. The current structure of local government in New Zealand inhibits systematic devolution, necessary if councils are to have more influence over local and regional outcomes. And New Zealand local government is unusual in the limited range of mandatory functions it is responsible for; indeed, The Economist described New Zealand as the most centralised nation in the OECD (31 October 2009, p. 59).

To create structures that would allow for a broader range of functions, New Zealand local government would need a more robust multi-level governance structure, with stronger regions and unitary councils in large metropolitan areas, in order to provide the necessary capacity and allow for greater redistribution. This would require regional councils to have a wider range of functions thus creating truly regional government, whereas their current focus is primarily on environmental policy and regulation, a form of limited governance. This would require the transfer of functions from both central government and territorial local authorities to the regional level. The policy question is what functions to devolve, and to which level of government. Table 40 suggests a distribution of 
functions that would shift New Zealand closer to the centre of the devolution spectrum.

Table $40 \quad$ Functions suitable for devolution

\begin{tabular}{|c|c|c|}
\hline $\begin{array}{l}\text { Regional and city- } \\
\text { region level }\end{array}$ & & \\
\hline & Minor roles in & $\begin{array}{l}\text { - } \text { Education - regional planning } \\
\text { (tertiary education) } \\
\text { - Employment } \\
\text { - Fire and rescue }\end{array}$ \\
\hline & Major roles in & $\begin{array}{l}\text { - Regional planning } \\
\text { - Public health } \\
\text { - Housing }\end{array}$ \\
\hline $\begin{array}{l}\text { District and city } \\
\text { level }\end{array}$ & & \\
\hline & Minor roles in & 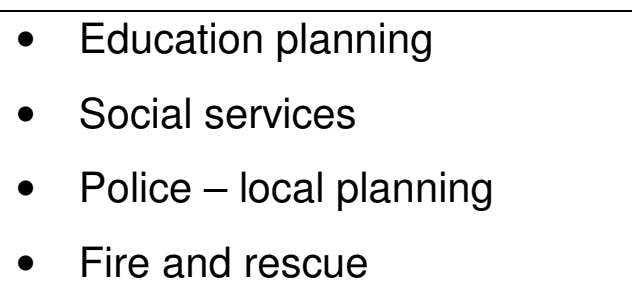 \\
\hline
\end{tabular}

The suggested changes to functions in Table 38 would allow councils at local and regional levels to provide more integrated services, and to influence service providers in order to address a much wider range of local issues. The rationale for the changes is as follows:

- Education: both spheres of local government have an interest in education, to raise the skills and competence of citizens and to ensure an appropriately qualified workforce for local business. Councils could play a more significant role in related activities, such as after-school care programmes and recreation. Increasingly schools are closing down their swimming pools and making more use of council-owned facilities. Such related activities should be funded under contract by central government. 
- Public health: the current distinction between councils' environmental health responsibilities and district health boards' public health responsibilities is arbitrary. Bringing these functions together under the local authority would allow more co-ordination and less duplication. Placing them at a regional level would ensure more capacity and consistency than is currently available at a territorial level. Many of these activities are funded through user charges or local levies; the additional responsibilities should be accompanied by the relevant share of funding allocated to district health boards.

- Police: local authorities have an important role, through urban planning, in community safety. Providing councils with a statutory role to develop local policing plans would allow more integrated and targeted local services.

- Fire and rescue: the current framework for these services is a mix of central and local provision. Allowing services to be tailored for local and regional needs has practical advantages.

- Social services: district and city councils (including city regions) are well placed to manage services based in neighbourhoods, particularly services catering for children and older people. Councils should be responsible for allocating national funding for such programmes. Current funding spent on these programmes by government departments should be provided to councils to allocate according to local circumstances.

- Employment: employment planning is undertaken mainly at a national level. To recognise the importance of city and regional economies, some regional capacity should be developed in association with national planning.

- Housing: while local government is already the second-largest social housing provider in New Zealand, its mandate is weak and many territorial authorities are reluctant providers. A regional approach to social housing could result in much more efficient allocation by ensuring that stocks match expected demand. This might involve the Housing New 
Zealand Corporation devolving responsibility for its housing stock to the local authority in some areas.

Besides shifting activities up or down a level, a properly defined regional level of government could resolve the fragmentation of some governmental services.

For example, New Zealand has 13 conservation boards, 21 district health boards, 12 Police districts, eight fire service regions, nine sub-national Historic Places Trust offices, 14 economic development regions, 11 Work and Income regions, and five Ministry of Education regions (see Gill 2008). A more comprehensive regional government would encourage horizontal integration, with regional authorities taking over some sub-national departmental functions, as well as aligning central government and regional government boundaries.

These suggestions for additional or complementary responsibilities would represent only a small change in the distribution of functional responsibilities between local and central government. And even then councils' role in the administration of government programmes would remain minor and they would still be largely self-funding. Although the additional responsibilities would operate primarily at the planning level (except for housing and public health), they would give councils more legitimacy for acting on and influencing local outcomes.

\section{Community planning}

Good community planning should enable citizens, local organisations, councils and central government agencies to agree some high level objectives for public investment to facilitate the achievement of local outcomes. Despite its statutory objectives, the New Zealand model of community planning has not brought about as much inter-agency planning or community engagement as might have been expected, given some of the official statements (see McKinlay 2006).

Some of the reasons for this are explained in earlier chapters; they concern the lack of mandatory participation by direct central government agencies, and the fact that compliance has overshadowed strategy in the structure and development of the LTCCP. 
Certain features of the Irish and English models might be employed to strengthen the New Zealand approach. The Irish model places emphasis on the regional co-ordination of public services. It brings together representatives of public agencies and partner organisations, to reduce duplication, improve integration and balance national strategies and local issues. In contrast, the English approach of seeking sustainable community strategies emphasises the articulation of local aspirations as a means of determining priorities for joined-up operational initiatives. In Ireland the local authority has responsibility for developing regional strategies, while in England this responsibility sits with the Local Strategic Partnership, of which the local authority is a lead agency (the council remains the default provider in the absence of such partnerships). The English approach is likely to fit more easily into the New Zealand local government framework given its similarities to the LTCCP regime, although some changes would be required. For example:

- relevant central government departments and agencies would be required to participate in the development of local and regional community strategies, through legislation or direction by the State Services Commission

- the community planning process would need better information as a basis for dialogue on setting goals and objectives for different localities. Such information might include, for example, a snapshot of public expenditure in each area

- the existing LTCCP model might need modification to separate organisational and accountability elements from community and strategic planning elements. This would give councils more flexibility to be innovative and make use of opportunities for joint planning with other agencies

- the level of compliance required for the community plan would have to be considerably reduced. The scale of the LTCCP and the fact that it is subject to an official audit reduce the freedom of local authorities to adapt their processes to connect with other agency frameworks. 
A separation of the strategic and organisational parts of the LTCCP, accompanied by mechanisms to guarantee the involvement of central government agencies, would create a community planning instrument with more capacity to achieve community governance than the LGA 2002 model.

\section{Institutional governance arrangements}

One of the dimensions assessed as having room for improvement was leadership. Since 1989, local government reform has, intentionally or unintentionally, left many elected members feeling superfluous and created a perception that the sector had become more technocratic and managerial, impinging on the roles of mayors and councillors. For example, the shift to a more principled approach to decision-making in which costs and benefits are required to be taken into account has given policy advisers much more scope to 'frame' issues and scope options. Even the shift to community outcomes, which was designed as a citizen-focused process, was regarded by some elected members as excluding them from the process and their rightful role to show leadership.

The research highlighted the deficiencies of the New Zealand system of 'weak' mayors and questioned the ability of this model to achieve the same degree of community leadership as the stronger mayors found in many overseas jurisdictions. Effective leadership is often an essential feature of community governance regimes through its ability to bring others along and sell a common vision. To strengthen the capacity of mayoral leadership Evans' (2003) recommendations should be examined, particularly allowing mayors to appoint their deputies and their committee chairs and play a larger role in the development of the annual budget. These measures would not only force mayors to lead from the front but also make them more accountable for decisions with regard to appointments and budget proposals, something that might increase public interest in local government. ${ }^{97}$

\footnotetext{
${ }^{97}$ Recent changes to the Queensland Local Government legislation have enhanced the role of directly elected mayors, including a decision to give them responsibility to oversee the preparation of the budget, which legislators believe will give the position greater public profile. (Interview between the author and the chief executive of the Queensland Local Government Association.)
} 
The democracy dimension was also assessed as showing room for improvement. Problem areas included the fact that the number of elected members relative to the number of citizens was decreasing, a trend likely to be exacerbated by the consolidation of Auckland. The solution is likely to be contentious. While improving representation will likely require increasing the number of elected members, setting a vision or goals and steering a course toward them can be easier with fewer decision-makers. However, small, focused decision-making groups pose a risk of policy capture or technocratic capture, particularly if political structures are weak and management relatively unsupervised.

Options for improving the balance between representation and governance include allowing more variation in council structures to match the different size and circumstances of councils. The United Kingdom, for example, allows councils to hold community polls to choose one of three different governance models, including a cabinet model which creates two classes of councillors. Executive councillors are selected for the cabinet while the remainder are responsible for scrutinising the cabinet's performance. Other approaches that might be considered are mandatory election of councillors by wards, mandatory proportional representation, and providing citizens with 'call-in' powers, for example, through local referenda. Each model has its strengths and weaknesses and policy consistency will need to be traded off against political diversity.

\section{Influencing national providers}

Much of community governance theory and practice involves increasing citizens' ability to influence the decisions taken by their elected and appointed officials. While community strategies can ensure that local authority planning and decision-making take account of the aspirations of local populations, it is more difficult to ensure that nationally determined policies and programmes, which arguably affect local development more, are similarly aligned with local priorities. The LGA 2002 encouraged many in local government to believe that the community outcomes process could be a mechanism to reorient central 
government spending in localities so as to focus on the unique issues of each place. As the case studies revealed, this expectation was largely unmet.

Ensuring government policies and programmes are sensitive to local conditions, as opposed to offering a 'one-size-fits-all' response, is the purpose of the Sustainable Communities Act 2007 (SCA), enacted by the British Parliament in 2007. The SCA creates a structured environment in which councils are invited to facilitate a process that allows citizens to make proposals for redirecting discretionary government spending in their communities. While it is too early to review the effectiveness of this initiative, New Zealand is well placed to introduce a similar approach as a pilot project, allowing for a structured evaluation. Interestingly, elements of this regime were reflected in the report of the Royal Commission on Auckland Governance in its recommendation that the Government detail the full extent of its social spending in the city. At the time of writing, it had not yet been endorsed by the Government.

\section{Joined-up government}

New Zealand local government was also assessed as having room for improvement on the collaboration indicator, reflecting the lack of formal or official mechanisms for facilitating joined-up government initiatives incorporating local approaches to planning. While a number of intergovernmental initiatives have been established, particularly since the passage of the LGA 2002, they vary considerably in form and structure and are limited in scope.

The number and effectiveness of locally joined-up initiatives might be increased by the creation of some form of legal entity with authority to hold and allocate resources. For example, under the Local Area Agreements used in the United Kingdom government departments, local authorities and other agencies can pool budgets in order to achieve outcomes for localities. Such agreements provide legal protection for government departments, organisations and local governments that enter into them, as they are bound by the same disclosure rules as the public sector. Such approaches have been discussed in New Zealand (see SSC 2001, SSC 2002) but have yet to result in any effective mechanisms for aligning councils and departments. More recently, interest in 
England has focused on the concept of 'Total Place', an initiative which has been undertaken in a number of pilot sites to bring together public and nonpublic service providers around locally determined outcomes. It does not appear that this initiative has been supported up by the new Conservative Liberal Democrat administration.

\section{Decision-making}

The decision-making dimension was assessed as having room for improvement even though local government in New Zealand has been at the forefront in its use of consultative democracy. Although the number of submissions continues to increase annually, the process, particularly the special consultative procedure, is inflexible and has been criticised for discriminating against less well-educated groups (New Zealand Government 2007). Also the number of council committees has gradually declined, reducing opportunities for citizens and organisations to exercise influence. Further research is needed into the implications of the shift away from traditional committees in favour of portfolio systems and its effects on citizens' access. Similarly, setting minimum representation standards for certain types of councils should also be considered. In addition, there are no public agencies concerned with promoting or monitoring the issue of civic participation or civics education; perhaps this is an issue the Human Rights Commission should examine and consider as part of its remit.

\section{Further research}

Community governance is a relatively new concept, yet to be accepted as mainstream local government. Examples of community governance in practice tend to be largely operational, focusing for example on inter-agency coordination or networks, rather than complete governance systems. Should community governance be institutionalised, it will have implications for intergovernmental relationships, which have already begun to change in some places, shifting from hierarchy to partnerships. This area is worthy of further research to understand its implications for day-to-day interactions, ways of achieving alignment toward common strategic goals, and decision-making 
about local government structures. Similarly, further investigation is required into the way successful partnerships can be established and sustained at the community level with the not-for-profit sector and business. As an approach to making public decisions, community governance has been developed to recognise and incorporate sectors that are often left out of the decision-making process so that a full place-based approach can be taken to managing the public domain. This has particular implications for Maori organisations, such as iwi, hapu and urban-based organisations, which have their own mandates and legitimacy. How the roles of iwi/Maori organisations are incorporated into a community governance approach is an area worthy of separate research.

A related area of research might be the implications of community governance for the role of elected members and the way they attempt to balance governance, stewardship and representation roles. What might it mean for the decision-making structures of councils, the number of councillors, and the way their remuneration is set? Having answered these questions, a further challenge would be to propose a legislative framework that promotes community governance while accommodating the diversity of councils and communities. Finally, a better understanding is needed of the factors that drive local government policy and particularly local government reform. Current research tends to focus on the effects of consolidation, modernisation or democratisation; unfortunately, we have a much poorer picture of their causes. Questions that might be asked are whether the drive for reform reflects a rational comprehensive analysis of local government systems; whether it reflects a crisis in global capitalism; or whether it is simply a reflection of the preferences of dominant individuals. Without an understanding of the drivers of change and their interaction, the ability to influence the direction of reform in the future is limited.

Two other issues are worthy of further research to determine their suitability for the New Zealand context. The first concerns whether or not New Zealand should adopt an equalisation policy for local government. Currently there is very little weighting to reflect socio-economic circumstances in the assistance councils receive from central government. This means that 'better off' 
communities are able to afford a greater range of local public services than low socio-economic communities. It represents a significant equity issue as the quality and quantity of local infrastructure can have a major effect on inward investment. Strengthening 'poor' councils may be an important precondition to strengthening community governance. A second issue worthy of study would be the place, if any, of binding referenda. In order to strengthen community voice there may be value in providing a mechanism that allows citizens to organise and seek an early election. Such a measure might be an effective way of addressing criticism that New Zealand local democracy is weak and lacks mandate. Such measures would need a range of checks and balances to guard against their frivolous use.

\section{Conclusion}

The community governance literature recommends that local authorities take an active interest in all issues affecting their localities (including those which are outside their administrative responsibilities) in an effort to achieve desired local outcomes. Local government plays a critical role in this as it provides the democratic legitimacy that allows citizens to make choices about the nature of their communities. This view of local government can be understood as a desire to rebalance political life by shifting authority from the centre towards the periphery and challenges the more traditional functionalist approach to local government, which defines councils primarily as service providers.

This thesis has identified a number of relatively instrumental changes that would better enable the local government system in New Zealand to adopt a community governance approach. These changes, by themselves, would gradually shift the balance of authority from central government towards the periphery by increasing the relevance of local authorities and thus public appreciation of their role. Broadly speaking, however, the reform of local government in New Zealand leaves the current constitutional arrangements untouched; councils still operate within the framework of parliamentary sovereignty and governments are perfectly able to change their minds about the role and function of the sector. The assessment in Chapter 7 suggests that 
while the current way of empowering councils is sufficient for a community governance approach to be adopted, it does expose local authorities to some risk, as it takes only a simple majority to change the sector's fundamental legislation. In the long term, if local government is to fully embrace a role of community governance and the locality is to be recognised as an important place in which public decisions should be made, a greater level of constitutional certainty around councils' powers and their role is needed. In a Westminster system this poses a number of questions about how this might be achieved, questions beyond the scope of this study. Strengthening the ability of councils to implement community governance in New Zealand requires re-examining the efficacy of the existing frameworks for empowering local government, their range of responsibilities, the adequacy of the policy levers available to councils, and their relationships with higher level government. While the LGA 2002 was influenced by the principles of community governance (especially the new localist stream), there has never been an official commitment to the overall concept.

The research results suggest that reform so far has been only partial in terms of achieving community governance and further suggestions have been made to address some of the gaps. In the meantime, efforts to strengthen community governance can be seen in some of the governance arrangements proposed by the Royal Commission on Auckland Governance (2009). The commission's proposals are an explicit recognition that different types of communities require different types of governance arrangements, given that existing arrangements for Auckland are generally the same as for all other regions of the country, even those with small, dispersed populations. Indeed, we might speculate that the Royal Commission's establishment itself signifies recognition that the idea of an undifferentiated system of local government is a thing of the past, and that demands for more locally and regionally differentiated governance solutions will occur increasingly. ${ }^{98}$ Most of all, however, the commission's recommendation for an integrated social board, with local and central government

\footnotetext{
${ }^{98}$ At the time of writing, public calls have been made for the creation of a large unitary council in Hawke's Bay, a petition has started to consolidate Nelson City and Tasman District, and the three mayors of Northland have called for each of their councils to be made unitary authorities and the Northland Regional Council to be removed.
} 
representatives, to oversee the Government's social spending in Auckland is a practical example of community governance in action. A community cannot effectively determine priorities for public investment if it lacks information about where current investment is allocated. The Government has initially rejected the model, proposing instead a regular social forum with the council, a suggestion that falls short of the original proposal, although it recognises the need for a more integrated approach.

The New Zealand system of local government is generally viewed as part of the Anglo tradition, characterised by a lack of constitutional status, minimal functions and a generally instrumental role. What then are the chances for achieving community governance? It would ultimately require a major shift in the relative responsibilities and authority of the state and local government. The state would need to change its perception of local government and reorient its policy-making and service delivery towards locally specific matters. Change may be inevitable; whether it occurs as a result of an ideological conversion (unlikely) or in recognition that the centre cannot deliver services to meet the needs and expectations of an increasingly diverse citizenry, the locality seems likely to play a bigger part in the governance of the country.

Recent local government reforms represent an ambitious project, and it is not clear that they have lived up to the more ambitious claims made for them, particularly the suggestion that they represent a shift from government to governance. This is a project still to be completed and, should the legislators be so inclined, international practice affords a few examples that could be considered as useful models.

\section{Postscript}

At the time of writing, the New Zealand Parliament is soon to debate the final bill in a legislative programme for the establishment of a new Auckland Council, covering a city region of over 1.4 million residents, more than a third of the nation's population. The Local Government Amendment (Auckland Law Reform) Bill has caused some controversy, as the Government has signalled an 
intention to create stand-alone Council Controlled Organisations (CCOs) to operate many of the major infrastructure services historically provided by the local authorities. The seven planned CCOs include Auckland Transport, responsible for all matters relating to roads and transport, and Auckland Water, responsible for waste water and potable water. In addition, CCOs will be established to undertake economic development, the operation of major facilities, the inner city and waterfront, and the council's commercial property portfolio.

Concern has been expressed that in solving the problem of territorial fragmentation the Government has introduced a new problem which might be described as functional fragmentation; 20 or so local boards, which will be given local decision-making powers, are included. The resulting challenge seems similar to that encountered by local authorities in Britain in the mid eighties with the beginning of a differentiated polity. The new council must devise a way to steer this mix of public and semi-public agencies, each with its specific objectives. The solutions so far proposed include a 20- to 30-year spatial plan to provide direction for the future development of Auckland and its infrastructure providers. In the social policy arena a Social Issues Forum, bringing together metropolitan and central government representatives, is under consideration. Faced with a greatly reduced range of operational levers, the new council will have little choice but to see its primary task as governance and ensuring agencies are working in the same direction, a direction established with the active participation of citizens. 


\section{Bibliography}

Aberbach, J., \& Christensen, T. (2003) Translating Theoretical Ideas into Modern State Reform: Economics Inspired Reforms and Competing Models of Governance, Administration and Society, Vol. 35, No. 5 pp $491-509$

Abercrombie, N., Hill, S., \& Turner, B. (1984) Dictionary of Sociology, Penguin Books, London.

Adshead, M., \& McIreney, C. (2008) Ireland's National Anti-Poverty Strategy as New Governance, in Considine, M., \& Giguere, S. (eds.) The Theory and Practice of Local Governance and Economic Development, Palgrave MacMillan, Basingstoke, United Kingdom.

Albrechts, L. (1991) Changing Roles and Positions of Planners, Urban Studies, Vol. 28, No. 1, pp 123 - 137.

Albrechts, L. (2001) How to Proceed from Image and Discourse to Action: As Applied to the Flemish Diamond, Urban Studies, Vol. 38, No. 4, pp $733-745$.

Albrow, M. (2001) Society as Social Diversity: The Challenge for Governance in the Global Age, in OECD (eds.) Governance in the 21st Century, OECD, Paris.

Allan, P. (2003) Why Smaller Councils Make Sense, Australian Journal of Public Administration, Vol. 63, No. 3, pp. 74-81.

Andrew, C., \& Goldsmith, M., (1998) From Local Government to Local Governance - and Beyond? The International Political Science Review, Vol. 19, No. 2, pp. 101-117. 
Baehler, K. (2003) Managing for Outcomes: Accountability and Thrust, Australian Journal of Public Administration, Vol. 62, No. 4, December, pp. 23-34.

Bailey, S. J. (1999) Local Government Economics: Principles and Practice, Palgrave Macmillan, Basingstoke, United Kingdom.

Banner, G. (2002) Community Governance and the New Central Local Government Relationship, International Social Science Journal, Vol. 54, No. 172, pp. 217-231.

Bassett, M. (1996) The Context of Local Government Reform: Politics, History and Place, the New Zealand Experience, in McDermott, P., Forgie, V., \& Howell, R. (eds.) An Agenda for Local Government, Massey University, Palmerston North.

Becki, U. (1999) The New Statesman Essay - Beyond the Nation State, New Statesman, viewed on 12 April 2009 at www.newstatesman.com/199912060017.

Bell, D. (1973) The Coming of Post-Industrial Society, Basic Books, New York.

Bertelsmann Stiftung (2001) Draft Governance Criteria for Local Government, viewed on 9 September 2007 at www.en.bertelsmann.stiftung.de.

Bingham, L. B., O'Leary, R., \& Nabatchi, T. (2005) Legal Frameworks for the New Governance: Processes for Citizen Participation in the Work of Government, National Civic Review, Vol. 94, No. 1, pp. 54-61.

Bogason, P. (2001) Postmodernism and American Public Administration in the 1990's, Administration and Society, Vol. 33, No. 2, pp. 165-193.

Boston, J. (1991a) The Theoretical Underpinnings of Public Sector Restructuring, in Boston, J., Martin, J., Pallot, J., \& Walsh, P. (eds.) 
Reshaping the State: New Zealand's Bureaucratic Revolution, Oxford University Press, Auckland.

Boston, J. (1991b) Re-organising the Machinery of Government: Objectives and Outcomes, in Boston, J., Martin, J., Pallot, J., \& Walsh P. (eds.)

Reshaping the State: New Zealand's Bureaucratic Revolution, Oxford University Press, Auckland.

Boston, J., Martin, J., Pallot, J., \& Walsh, P. (1996), Public Management - The New Zealand Model, Oxford University Press, Auckland.

Boswell, D. (1981) Local Government, self-published monograph, New Zealand.

Bovaird, T., \& Loffler, E. (2003) (eds.) Public Management and Governance, Routledge, New York.

Bovaird, T., \& Loffler, E. (2007) Assessing the Quality of Local Governance: A Case Study of Public Services, Public Money and Management, Vol. 27, No. 4, pp. 293-300.

Brookings Institution (2003) Back to Prosperity: A Competitive Agenda for Renewing Pennsylvania, Brookings Institution, Washington DC.

Bryson, J. M. (2004) Strategic Planning for Public and Non Profit Organizations - A Guide to Strengthening and Sustaining Organizational Achievement, Jossey-Bass, San Francisco.

Buchanan, J. (1995/96) Federalism and Individual Sovereignty, Cato Journal, Vol. 15, Nos. 2-3, pp. $259-268$.

Bush, G. (1995) Local Government and Politics in New Zealand, second edition, Auckland University Press, Auckland. 
Cameron, D. (2009) Control Shift: Returning Power to Local Communities, viewed on 5 April 2009 at www.conservatives.com.

Cashin, S. (2000) Localism, Self-Interest and the Tyranny of the Favored Quarter: Addressing the Barriers to New Regionalism, GeorgeTown Law Journal, 88, pp. 1985-2048.

Chapman, R. (2005) Government Strategies and Community Outcomes under the Local Government Act 2002, working paper viewed on 1 April 2009 at www.victoria.ac.nz/localfutures.

Cheyne, C. (2002) Public Involvement in Local Government in New Zealand: A Historical Account, in Drage, J. (ed.) Empowering Communities: Representation and Participation in New Zealand's Local Government, Victoria University Press, Wellington.

Cheyne, C. (2008) Empowerment of Local Government in New Zealand: A New Model for Contemporary Local-Central Relations? Commonwealth Journal of Local Governance, Issue 1, May, viewed on 1 April 2009 at http://epress.lib.uts.edu/ojs/index.php/cjlg

Cheyne, C., \& Comrie, M. (2002) Involving Citizens in Local Government: Expanding the Use of Deliberative Democracy, in Drage, J. (ed.) Empowering Communities? Representation and Participation in New Zealand's Local Government, Victoria University Press, Wellington.

Clough, P., \& Nutbrown, C. (2002) A Student's Guide to Methodology, Sage Publications, London.

Coaffee, J. (2005) New Localism and the Management of Regeneration, International Journal of Public Sector Management, Vol. 18, No. 2, pp. 108-113. 
Considine, M. (2006) Partnership and Collaborative Advantage: Some Reflections on New Forms of Network Governance, The Centre for Public Policy, Melbourne University, Melbourne.

Considine, M., \& Giguere, S. (2008) The Partnership Agenda Going Forward, in Considine, M., \& Giguere, S. (eds.) The Theory and Practice of Local Governance and Economic Development, Palgrave Macmillan, Basingstoke, United Kingdom.

Cookson, J. (2007) How British? Local Government in New Zealand to c1930, The New Zealand Journal of History, Vol. 41, No. 2, pp. 143-160.

Darlow, A., Hawtin, M., Jassi, S., Monroe, S., Percy-Smith, J., \& Purcell, M. (2008) Formative Evaluation of Community Strategies, 2004-2007: Final Report, Policy Research Institut, Leeds Metropolitan University, Leeds.

Davies, J. (2009) The Limits of Joined-up Government: Towards a Political Analysis, Public Administration, Vol. 87, No. 1, pp. 80-96.

De Bres, J. (2002) Departmental Statements of Intent - Lessons Learned from Three Years Experience, Public Sector Journal, Vol. 25, No. 2, pp. 26-28.

Dempsey, N. T. D. (2000) A New Vision for Our Counties and Cities, Department of Environment and Local Government, Dublin, Ireland, viewed on December 2007 at www.cdb.ie/pdf/taskfrcdocs/A\%20New\%20Vision\%20for\%20our\%20 Counties\%20and\%20Cities.pdf.

Dent, M., Van Gestel, N., \& Teelken, C. (2007) Symposium on Changing Modes of Governance in Public Sector Organisations: Action and Rhetoric, Public Administration, Vol. 85, No. 1, pp. 1-8. 
Dollery, B. (2008) Funding: Local Government New Zealand Conference 2008, viewed on January 2010 at www.Ignz.co.nz/library/publications/Funding_LGNZ.pdf.

Dollery, B., \& Johnson, A. (2005) Enhancing Efficiency in Australian Local Government: An Evaluation of Alternative Models of Municipal Governance, Urban Policy and Research, Vol. 23, No. 1, pp. 73-85.

Dollery, B., \& Robotti, L. (2008) The Theory and Practice of Local Government Reform, Edward Elgar, Cheltenham, United Kingdom.

Dollery, B., \& Wallis, J. (2001a) The Political Economy of Local Government: Leadership, Reform and Market Failure, Edward Elgar, Cheltenham, United Kingdom.

Dollery, B., \& Wallis, J. (2001b) The Theory of Market Failure and Policy Making in Contemporary Local Government, Discussion Paper 0121. Department of Economics, University of Otago, Dunedin, New Zealand (Unpublished).

Drage, J. (2003) The Impact of the New Local Government Legislation on Political Representation, Public Sector, Vol. 26, No. 2, pp. 11-16.

Drage, J. (2008) A Balancing Act: Decision-making and Representation in New Zealand's Local Government, Institute of Policy Studies, Victoria University, Wellington.

Elwood, B. (1993) A Brief Reflection on Local Government Reform, Public Sector: The Publication of the New Zealand Institute of Public Administration, Vol. 16, No. 3, pp. 2-4. 
Etzioni, A. (1996) The New Golden Rule: Community and Morality in a Democratic Society, Basic Books, New York.

Evans, M. (2003) Leadership and the Role of Mayor in New Zealand, unpublished thesis for Master of Social Science, University of Waikato, Hamilton.

Filkin, G., Stoker, G., Wilkinson, G., \& Williams, J. (2000) Towards a New Localism - A Discussion Paper, New Local Government Network, London.

Fisher, F., \& Tees, D. (2005) Key Competencies for Improving Local Governance, United Nations Human Settlements Programme, Nairobi, Kenya.

Florida, R. (2002) The Rise of the Creative Class, Washington Monthly, viewed on 3 February 2009 at www.washingtonmonthly.com/features/2001/0205.florida.html.

Florini, A., (2005) The Coming Democracy: New Rules for Running a New World, Brookings Institution, Washington DC.

Forgie, V. (2002) Submission Makers' Perceptions of the Annual Planning Process, in Drage, J. (ed.) Empowering Communities? Representation and Participation in New Zealand's Local Government, Victoria University Press, Wellington.

Foster, K., Perry, D., Price, A., Sheffer, J., \& Taylor, Jnr. H. (1997) Governance in Erie County - A Foundation for Understanding and Action, Governance Project, State University of New York, Buffalo, viewed on 10 February 2006 at www.regional-institutebuffalo.edu.gove_repo/contents.html. 
Fukuyama, F. (1989) The End of History? in The National Interest, viewed on 20 May 2006 at http://www.viet-studies.org/endofhistory.htm.

Fukuyama, F. (1999) The Great Disruption: Human Nature and the Reconstitution of Social Order, Profile Books, London.

Gallop, G. (2006) Towards a New Era of Strategic Government, The Australia and New Zealand School of Government (ANZSOG) Public Lecture Series, Acton, 25 October, viewed on 1 October 2009 at http://epress.anu.edu.au/anzsog/policy/mobile_devices/ch07s10.html.

Galston, W., \& Levine, P. (1997) America's Civic Condition, The Brookings Review, Vol. 15, No. 4, pp. 23-26.

Garcea, J., \& LeSage, E. Jr. (2008) Local Government Reforms in Canada, in Dollery, B., Garcea, J., \& LeSage, E. Jr. (eds.) Local Government Reform: A Comparative Analysis of Advanced Anglo-American Countries, Edward Elgar, Cheltenham, UK.

Gaventa, J. (2004) Strengthening Participatory Approaches to Local Governance: Learning Lessons from Abroad, National Civic Review, Vol. 93, No. 4, pp $16-27$.

Geddes, M. (2001) Report on Regional Partnerships in Norway, OECD LEED Programme Study on Local Partnerships, Local Government Centre, University of Warwick, Warwick, England.

Geddes, M. (2005) International Perspectives and Policy Issues, in Smyth, P., Reddel, T., \& Jones, A. (eds.) Community and Local Governance in Australia, UNSW Press, Sydney.

Giddens, A. (1999) Democracy, Reith Lecture \#5, viewed on 21 July 2007 at http://news.bbc.co.uk/hi/english/static/events/reith_99/week5.htm. 
Giddens, A. (2000) The Third Way and its Critics, Polity Press, Cambridge, UK.

Giguere, S. (2008) The Use of Partnerships in Economic and Social Policy, in Considine, M., \& Giguere, S. (eds.) The Theory and Practice of Local Governance and Economic Development, Palgrave Macmillan, Basingstoke, UK.

Gill, D. (2008) By Accident or Design: Changes in the Structure of the State of New Zealand, Policy Quarterly, Vol. 4, No. 2, pp. 27-32.

Gilling, B., \& Henderson, A. (2000) Town and Country: The National Associations and Insurance Companies of Local Government in New Zealand, Local Government New Zealand, Wellington.

Gootman, M. (1998) Metropolitan Partnerships in the United Kingdom: Lessons for the United States, unpublished paper prepared for the UK Atlantic Fellow in Public Policy.

Gough, R. (2009) With a Little Help From Our Friends, Localis, viewed on 2 February 2009 at www.localis.org.uk.

Greasley, S., \& Stoker, G. (2008) Political Leadership in Local Governance, in Roxburgh, (ed.) Next Steps for local Democracy: Leadership, Accountability and Partnership, New Local Government Network, London.

Guerin, K. (2002) Subsidiarity: Implications for New Zealand, New Zealand Treasury Working Paper, The Treasury, Wellington.

Gurria, A. (2007) Opening speech to the OECD conference, What Policies for Globalising Cities? Rethinking the Urban Policy Agenda, Madrid, 29 March 2007. 
Habermas, J. (1992) Further Reflections on the Public Sphere, in Calhoun, C. (ed.) Habermas and the Public Sphere, MIT Press, Cambridge MA.

Hambleton, R. (2008) Civic Leadership for Auckland: An International Perspective, Briefing paper for the Royal Commission on Auckland Governance, viewed on December 2008 at www.dia.govt.nz.

Harmsworth, K. (2001) Glocalism: The Growing Importance of Local Space in the Global Environment, Canada West Foundation, viewed on 1 May 2007 at www.cwf.ca/abcalcwf/doc.

Hide, R. (2009) Ministerial address, Local Government New Zealand Conference, 28 July, Christchurch, viewed on September 2009 at www.lgnz.co.nz.

Holden, B. (1974) The Nature of Democracy, Thomas Nelson and Sons, Great Britain.

Howell, R., McDermott, P., \& Forgie, V. (1995) Governance and Management in New Local Government, Occasional Papers in Local Government Studies, Massey University, Palmerston North.

Huxham, C. (2003) Theorizing Collaborative Practice, Public Management Review, Vol.5, No. 3, pp. 401-423.

ICLEI (2002) National Strategy for Local Impact in Norway, viewed on 13 August 2008 at www3.iclei.org/localstrategies/summary/norway2.html.

Imperial, M. (2005) Using collaboration as a governance strategy: lessons from six watershed management programs, Administration and Society, Vol. 37, pp. 281-320. 
Innes, J. (1996) Planning Through Consensus Building - A New View of the Comprehensive Planning Ideal, APA Journal, Autumn, pp. 460-472.

Jensen, L., \& Nielson, D. (2001) When Government Strikes Back - Assessing New Steering Tools in Danish Social Policy, paper for annual EGPA conference, viewed on 2 February 2008 at www.iiasiisa.org/egpa/e/service/publications/Documents/potspapers.pdf.

John, P. (2001) Local Government in Western Europe, Sage Publications, London.

Jones, G., \& Stewart, J. (1983) The Case for Local Government, George Allen and Unwin, London.

Julian, J. (2004) Integrated Decision-Making and Co-ordination through the Local Government Act 2002 - What Are the Barriers to Achieving Local Central Government Relationships to Further Community Outcomes? unpublished Master's thesis, Victoria University, Wellington.

Katz, B. (2007) A Blueprint for American Prosperity: What the 2008 Elections Should be About ... and How to Make it Happen, Presentation to the Brookings Council, New York viewed on 10 April 2009 at www.brookings.edu/speeches/2007/0523metropolitanpolicy_katz.asp $\mathrm{x}$

Keating, M. (1991) Comparative Urban Politics: Power and the City in the USA, Canada, Britain and France, Edward Elgar, Cheltenham, UK.

Kelsey, J. (1994) Aotearoa/New Zealand: The Anatomy of a State in Crisis, in Sharp, A. (ed.) Leap into the Dark, The Changing Role of the State in New Zealand, Auckland University Press, Auckland. 
Kerr, R. (2003) Weakening the Constitutional and Economic Framework: The Local Government Act 2002, Public Sector Journal, Vol. 26, No. 2, pp. 6-11.

Kettl, D., Pollitt, C., \& Svara, J. (2004) Towards a Danish Concept of Public Governance: An International Perspective, Report to the Danish Forum for Top Executive Management, viewed on 3 April 2009 at www.publicgovernance.dk.

Kjaer, A. (2004) Governance, Polity Press, Boston, MA.

Klein, N. (2001) Reclaiming the Commons, New Left Review, No. 9, May/June, pp. 81-89.

Kleinman, M., Burton, P., Croft, J., \& Travers, T. (2002) Links between the Finance and Non-finance Elements of Local Government: A Literature Review, Office of the Deputy Prime Minister, London.

Ladd, E. (1998) Bowling with Tocqueville: Civic Engagement and Social Capital, Bradley Lecture, American Enterprise for Public Policy Research viewed on 27 August 2007 at www.aei.org/bradley/b1091598.htm.

Lakoff, S. (1996) Democracy: History, Theory, Practice, Westview Press, Boulder CO.

Larsen, H., \& Offerdal, A. (2000) Policy Implications of the New Norwegian Local Government Act 1992 in Amna, A., \& Montin, S. (eds.) Towards a New Concept of Local Self Government?, Fagbokforlaget, Bergen.

Lawson, S., \& Gleeson, B. (2005) Shifting Urban Governance in Australia in Smyth, P., Reddel, T., \& Jones, A., (eds.) Community and Local Governance in Australia, UNSW Press, Sydney. 
Lee, S., (2001) First Reading Speech of the Local Government Amendment Bill, Hansard, Wellington.

Leonard, L., \& Memon, A. (2008) Community Outcome Processes as a Forum for Community Governance, International Global Change Institute, University of Waikato, Hamilton.

Livable Communities (2000) Building Livable Communities - Sustaining Prosperity, Improving Quality of Life, Building a Sense of Community: A Report from the Clinton Gore Administration, Government Printing Office, Washington D.C.

Local Futures (2006) Local Government, Strategy and Communities, Institute of Policy Studies, Victoria University Press, Wellington.

Local Government Association (2006) Closer to People and Places - A New Vision for Local Government, Local Government Association, London.

Local Government Forum (1999) Refocusing the Role of Local Government, Local Government Forum, Wellington.

Local Government New Zealand (2006) Devolution: Fact or Fiction, accessed on June 2009 from www.lgnz.co.nz.

Loffler, E. (2003) Governance and Government, in Bovaird, T., \& Loffler, E. (eds.) Public Management and Governance, Routledge, New York.

Logan, B. (1991) Review of State Sector Reforms, State Services Commission, Wellington.

Loughlin, J., \& Martin, S. (2004) Options for Reforming Local Government Funding to Increase Local Streams of Funding: International Comparisons, prepared for Lyons Inquiry into Local Government 
Funding, viewed on 15 June 2008 at www.clrgr.cf.ac.uk/publications/reports.

Loughlin, M. (1986) Local Government in the Modern State, Sweet and Maxwell, London.

Lowndes, V., \& Wilson, D. (2003) Balancing Revisability and Robustness? A New Institutionalist Perspective on Local Government Modernisation, Public Administration, Vol. 81, No. 2, pp. 275-298.

Lyons, M. (1996) Non-Profit Sector or Civil Society: Are they Competing Paradigms? Paper delivered to the Social Cohesion, Justice and Citizenship Biennial Conference of Australian and New Zealand, Third Sector Research, July 1996, Wellington.

Lyons, M. (2007) Place-shaping: A Shared Ambition for the Future of Local Government Final Report, The Stationery Office, London.

Marsh, A., \& Kay, A. (2004) Contextualizing Tiebout: Mobility, Municipalities and Methodology, School for Policy Studies Working Paper Series Bristol University Working Paper, No. 8, viewed on 24 July 2007 at www.bristol.ac.uk.

Marshall, N., \& Sproats, K. (2000) Managing Democracy? Assessing some of the Outcomes of Australian Local Government Reform, paper presented to the Local Government at the Millennium Conference, University of New South Wales, Sydney.

Matkin, D., \& Frederickson, G. (2009) Metropolitan Governance: Institutional Roles and Interjurisdictional Cooperation, Journal of Urban Affairs, Vol. 31, No. 1 pp. 45-66. 
McKinlay, P. (ed.) (1990) Redistribution of Power? Devolution in New Zealand, Institute of Policy Studies, McKinlay, P. (ed.) Victoria University, Wellington.

McKinlay, P. (1996) Local Government Reform: What was Ordered and What was Delivered, Local Government New Zealand, Wellington.

McKinlay, P. (2004) Realising the Potential of the Community Outcome Process - a report prepared to assist local authorities and other agencies use the community outcomes process to achieve sustainable improvements in community well-being, prepared by McKinlay Douglas Ltd. for Local Government New Zealand, Local Government New Zealand, Wellington.

McKinlay, P. (2005) Local Government and Local Governance: Putting the Community into Recreation, paper delivered to the NZ Recreation Association National Conference, November, Wellington.

McKinlay, P. (2006) Local Government Structure and Efficiency: A Report Prepared for Local Government New Zealand, Local Government New Zealand, Wellington.

McNeill, J. (2008) The Public Value of Regional Government: How New Zealand's Regional Councils Manage the Environment, unpublished thesis for a Doctor of Politics, Massey University, Palmerston North.

McNeill, J., Reid, M., \& Scott, C. (2008) Planning the Future: New Zealand Local Governments, Communities and Long Term Council Community Plans, refereed paper presented to the Governments and Communities in Partnership Conference, Centre for Public Policy, University of Melbourne, Melbourne.

Milner, H. (2002) Civic Literacy: How Informed Citizens Make Democracy Work, University Press of New England, Hanover, $\mathrm{NH}$ 
Mishra, R. (1999) Globalisation and the Welfare State, Edward Elgar, Cheltenham, UK.

Mitchell, C. (2003) The New Local Government Legislation, Public Sector, Vol. 26, No. 2, pp. 2-6.

Montin, S. (2000) A Conceptual Framework, in Amna, A., \& Montin, S. (eds) Towards a New Concept of Local Self Government?, Fagbokforlaget, Bergen.

Moore, M. (1995) Creating Public Value - Strategic Management in Government, Harvard University Press, Cambridge, MA.

Muhlberger, P. (2000) Defining and Measuring Deliberative Participation and Potential: A Theoretical Analysis and Operationalization, paper prepared for the International Society of Political Psychology, 23rd Annual Scientific Meeting.

Naschold, F. (1997) The Dialectics of Modernising Local Government - An Assessment for the mid-90's and an Agenda for the 21st Century, Science Centre, Berlin.

New Zealand Business Roundtable (2007) Submission to the Royal Commission on Auckland Governance, viewed on May 2008 at www.nzbr.co.nz.

New Zealand Labour Party, (1999) Local Government Election Manifesto, New Zealand Labour Party, Wellington.

New Local Government Network, (2008) Making Place Shaping a Reality, viewed on April 2009 at www.nlgn.org.uk/public/wpcontent/uploads/making-place-shaping-a-reality.pdf. 
Nogeste, K. (2006) Development of a Method to Improve the Definition and Alignment of Intangible Project Outcomes with Tangible Project Outputs, unpublished thesis for a Doctor of Project Management. RMIT University, Melbourne.

Norton, A. (1994) International Handbook on Local and Regional GovernmentA Comparative Analysis of Advanced Democracies, Edward Elgar, Cheltenham, United Kingdom.

Novak, M. (1996) To Empower People: From State to Civil Society, 20th Century Edition, AEI Press, Washington DC.

Oates, W. (1972) Fiscal Federalism, Harcourt Brace Jovanovich, New York.

Oates, W. (1999) An Essay on Fiscal Federalism, Journal of Economic Literature, Vol. 37, Issue 3, pp. 1120-1149.

OECD (2000) The Reform of Metropolitan Governance, viewed on 10 October 2008 at www.oecd.org/dataoecd/3/17/1918016.pdf.

O'Looney, J. (2004) The New Home Rule: A Regionalism Alternative, Supplement, or Distraction, National Civic Review, Vol. 93, Issue 1, pp. 16-27.

Orr, K. (2005) Three Versions of Stoker, Public Administration, Vol. 83, No. 2, pp. 297-321.

Osborne, D., \& Gaebler, T. (1992) Reinventing Government, Addison-Wesley, Reading, MA.

Page, E., \& Goldsmith, M. (1987) Centre and Locality, Explaining Cross National Variation, in Page, E., \& Goldsmith, M., (eds.) Central and Local Government Relations, SAGE Publications, London. 
Pallot, J. (1991) Financial Management Reform, in Boston, J., Martin, J., Pallot J., \& Walsh, P. (eds.) Reshaping the State: New Zealand's Bureaucratic Revolution, Oxford University Press, Auckland.

Parsons, W. (1997) Public Policy: An Introduction to the Theory and Practice of Policy Analysis, Edward Elgar, Cheltenham, United Kingdom.

Paytas, J. (2001) Does Governance Matter? The Dynamics of Metropolitan Governance and Competitiveness, viewed on 1 April 2009 at www.cmu.edu/ced/publications/governancematter.pdf.

Peters, G. (1996) Models of Governance, in Kettl, D., \& Millward, H. (eds.) State of Public Management, Johns Hopkins University Press, Baltimore, MD.

Putnam, R. (1995) Bowling Alone, Journal of Democracy, Vol. 6, No. 1, pp. 6578.

Reddel, T. (2005) Local Social Governance and Citizen Engagement, in Smyth, P., Reddel, T., \& Jones, A. (eds.) Community and Local Governance in Australia, UNSW Press, Sydney.

Reid, M. (1994) Local Government - Service Delivery or Governance, Public Sector Journal, Vol. 17, No. 2, pp. 2-6.

Reid, M. (1999) The Central-Local Government Relationship: The Need for a Framework? Political Science, Vol. 50, No. 2, pp. 165-182.

Reid, M. (2002) Exploring the Rhetoric of Partnership: The Dynamics of Local Government Reform in New Zealand, in Drage, J. (ed.) Empowering Communities? Representation and Participation in New Zealand's Local Government, Victoria University Press, Wellington. 
Reid, M. (2008) Harmonising National and Local Goals, in Considine, M., \& Giguere, S. (eds.) The Theory and Practice of Local Governance and Economic Development, Palgrave Macmillan, Basingstoke, UK.

Reid, M., McNeill, J., \& Scott, C. (2007) Community Strategic Planning and the Pursuit of Whole of Government Outcomes, paper presented to the Commonwealth Local Government Forum conference, Auckland, March 2007.

Rhodes, R. (1997) Understanding Governance: Policy Networks, Governance, Reflexivity and Accountability, Open University Press, Buckingham, UK.

Rhodes, R. (2007) Understanding Governance: Ten Years On, Organization Studies, Vol. 28, No. 8, pp. 1243-1264.

Richardson, M. (1999a) Taking the Canterbury Communities into the New Millennium: The Role of Government, Christchurch City Council, Christchurch.

Richardson, M. (1999b) Community Governance: Resource Kit, viewed on 23 March 2009 at www.ccc.govt.nz.

Richardson, M. (2005) Reflections on What was Achieved in the Local Government Act 2002, viewed on 7 April 2009 at www.waikato.ac.nz/igci/pucm/Linked\%20documents/LGAdiscussion.pdf.

Roberts, N. (2000) Wicked Problems and Network Approaches to Resolution, International Public Management Review, Vol. 1, Issue 1, pp. 1-19.

Ryan, B. (2003) Harder Yards Ahead: The Second Stage of Public Sector Reform in New Zealand, paper presented to the KAPA/ICAM 
International Conference on Advances in Management, Seoul, 16-19 July.

Sabel, C. (2001) A Quiet Revolution of Democratic Governance: Towards Democratic Experimentalism, in Governance in the 21st Century, OECD, Paris.

Sandel, M. (1996) Democracy's Discontent: America in Search of a Public Philosophy, Belknap Press, Harvard University, Cambridge, MA.

Sassen, S. (2006) Denationalised States and Global Assemblages, an Interview with Saskia Sassen, viewed on 12 December 2007 at www.eurozine.com/articles/2006-11-20-sassen-en.html.

Savitch, H. (1998) Global Challenge and Institutional Capacity or How We Can Refit Local Administration for the Next Century, Administration and Society, Vol. 30, No. 3, pp. 248-273.

Schick, A. (2001) Reflections on the New Zealand Model, viewed on 5 January 2008 at http://www.treasury.govt.nz/publications/mediaspeeches/guestlectures/schick-aug01/schick-rnzm01.pdf

Schout, A., \& Jordan, A. (2005) Coordinated European Governance: Self Organizing or Centrally Steered? Public Administration, Vol. 83, No. 12, pp. 201-220.

Scott G. (2001) Public Management in New Zealand - Lessons and Challenges, New Zealand Business Roundtable, Wellington.

Sellers. J., \& Lidstrom, A. (2007) Decentralisation, Local Government and the Welfare State in Governance, An International Journal of Policy, Administration and Institutions, Vol. 20, No. 4, pp. 609-632. 
Sen, A. (1999) Democracy as a Universal Value, Journal of Democracy, Vol. 10, No. 3, pp. 3-17.

Shah, A. (2006) A Comparative Institutional Framework for Responsive, Responsible, and Accountable Local Governance, in Shah, A. (ed.) Local Governance in Industrial Countries, World Bank, Washington DC.

Siedentop, L. (1994) Tocqueville, Oxford University Press, Oxford.

Sirianni, C., \& Friedland, L. (2001) Civic Innovation in America: Community Empowerment, Public Policy and the Movement for Civic Renewal, University of California Press, Los Angeles.

Skelcher, C., Navdeep, M., \& Smith, M. (2004) Negotiating the Institutional Void: Discursive Alignments, Collaborative Institutions and Democratic Governance, paper presented at the Political Studies Association Conference, April 2004, University of Lincoln, UK, available from www.inlogov.bham.ac.uk/research/partnership_outputs.shtml.

Smith, P., \& Stewart, K. (1998) Making Local Accountability Work in British Columbia, Ministry of Municipal Affairs, British Columbia.

Smyth, P., Reddel, T., \& Jones, A. (2005) Associational Governance in Queensland, in Smyth, P., Reddel, T., \& Jones, A. (eds.) Community and Local Governance in Australia, UNSW Press, Sydney.

Stewart, J. (2004) The Meaning of Strategy in the Public Sector, Australian Journal of Public Administration, Vol. 63, No. 4, pp. 9-11.

Stewart, J., \& Clarke, M. (1994) The Local Authority and the New Community Governance, Regional Studies, Vol. 28, No. 2, pp. 201-208. 
Stewart, J., \& Clarke M. (1996) Developments in Local Government, Institute of Local Government Studies Discussion Paper, University of Birmingham, Birmingham.

Stoker, G. (2000) From New Management to New Labour: Tensions and Hopes in the Reform of British Local Government, in Amna, E., \& Montin, S. (eds.) Towards a New Concept of Local Self Government?, Fagbokforlaget, Bergen.

Stoker, G. (2002) Life is a Lottery: New Labour's Strategy for the Reform of Devolved Governance, Public Administration, Vol. 80, No. 3, pp. 417434.

Stoker, G. (2005) New Localism, Participation and Networked Community Governance, paper prepared for the 6th Global Forum on Reinventing Government, University of Manchester, UK, accessed from www.ipeg.org.uk.

Sullivan, H. (2008) Meta-evaluation of the Local Government Modernisation Agenda in The State of Governance of Places: Community Leadership and Stakeholder Engagement, Department for Communities and Local Government, viewed on 1 October 2009 at www.odpm.gov.uk.

Sullivan, H., Barnes, M., \& Matka, E. (2006) Collaborative Capacity and Strategies in Area Based Initiatives, Public Administration, Vol. 84, No. 2, pp. 289-310.

Sutch, W. (1956) Local Government in New Zealand - A History of Defeat, in Polaschek, R. (ed.) Local Government in New Zealand, NZ Institute of Public Administration and Oxford University Press, Wellington.

Tarschys, D. (2001) Wealth, Values, Institutions: Trends in Government and Governance, in Governance in the 21st Century, OECD, Paris. 
Thiesse, A. (1999) Democracy Softens Forces of Change: Inventing National Identity, Le Monde Diplomatique, viewed on 11 November 2006 at http://www.monde-diplomatique.tr/en/1999/06/?c=05thiesse.

Thomas, S., \& Memon, A. (2007) New Zealand Local Government at the Crossroads? Reflections on the Recent Local Government Reforms, Urban Policy \& Research, Vol. 25, No. 2, pp. 171-185.

Tuffield, J. (2002) Lessons from the SOI Journey, Public Sector Journal, Vol. 25, No. 2, pp. 9-11.

UNDP (2005) Definition of Governance, accessed in January 2010 from http://www.adbi.org/discussionpaper/2005/09/26/1379.governance.indonesia.comments/definition.of .governance/.

UTS (2007) Principles for Effective Local Government Legislation in the Pacific: Background Paper, prepared for the Commonwealth Local Government Forum Regional Workshop, Suva.

Valaskakis, K. (2001) Long-term Trends in Global Governance from Westphalia to Seattle, in Governance in the 21st Century, OECD, Paris.

Vargas Llosa, M. (2001) The Culture of Liberty, Foreign Policy, Jan/Feb, pp. 6671.

Warner, M. (2001) Building Social Capital: The Role of Local Government, Journal of Socio-Economics, No. 30, pp. 187-192.

Webber, D. (2005) Wrestling with Outcomes: The New Zealand Experience, Public Sector, Vol. 28, No. 1, pp. 8-14. 
Wells, P., \& Goudies, R. (2005) Process Evaluation of Plan Rationalisation, Formative Evaluation of Community Strategies, Policy Research Institute, Leeds University, Leeds.

Whittington, R. (1993) What is Strategy - And Does it Matter?, Routledge, London.

Wilkinson, G., \& Monkhouse, E. (1994) Strategic Planning in Public Sector Organisations, Executive Development, Vol. 7, pp. 16-19.

Williamson, A. (1999) New Models of Governance in Ireland: The European Union and the Involvement of the Voluntary and Community Sector in Multi-level Partnerships in the 1990s, in Partnership - from Practice to Theory, Policy Paper no. 2, Institute of Policy Studies Victoria University, Wellington.

Wolman, H. (2008) Comparing Local Government Systems across Countries: Conceptual and Methodological Challenges to Building a Field of Comparative Local Government Studies, Environment and Planning C: Government and Policy, Vol. 26, pp. 87-103.

World Bank (1991) Managing Development - The Governance Dimension, viewed on December 2009 at http://wwwwds.worldbank.org/external/default/WDSContentServer/WDSP/IB/20 06/03/07/000090341_20060307104630/Rendered/PDF/34899.pdf.

World Bank (2000) Cities in Transition: World Bank Urban and Local Government Strategy, The World Bank, Washington DC.

Worrall, L., Collinge, C., \& Bill, T. (1998) Managing Strategy in Local Government, International Journal of Public Sector Management, Vol. 11, pp. 472-493. 


\section{Official publications}

Audit Commission (2004) People, Places and Prosperity, Millbank, London.

Communities and Local Government (2008) Creating Strong Safe and Prosperous Communities: Statutory Guidance, viewed on 25 March at www.communities.gov.uk.

Communities and Local Government (2008) Communities in Control: Real People, Real Power, viewed on 8 November 2008 at www.communities.gov.uk.

Communities and Local Government, (2008) Sustainable Communities Act 2007: A Guide, viewed on 3 July 2009 at www.communities.gov.uk.

Communities and Local Government (2009) Reforming Local Government: impacts and interactions of central government policies from 2000 to 2006, viewed on 1 August 2009 at www.communities.gov.uk.

Danish Nature and Forest Agency (2006) New Responsibilities - The Reform of Local Government Structure Gives Municipalities New Autonomy, viewed on 5 February 2008 at www.sns.dk/udgivelser/2006/87-7279728-2/html.

Department of Environment and Local Government (2000) A Shared Vision for County/City Development Boards: Guidelines on the CDB Strategies for Economic, Social and Cultural Development, Department of Environment and Local Government, Dublin.

Department of Environment and Local Government (2000) Modernising Local Government: The Challenge for Local Government, Department of Environment and Local Government, Dublin. 
Department of Environment and Local Government (2003) Review of County/City Development Boards Strategies, Department of Environment and Local Government, Dublin, viewed on 5 December 2007 at http://www.cdb.ie/stat.htm.

Department of Environment, Transport and Regions (1998) Modern Local Government: In Touch with the People, Department of Environment, Transport and the Regions, Eland House, London.

Department of Internal Affairs (2000) Statement of Policy Direction for the Review of the Local Government Act 1974, Department of Internal Affairs, Wellington.

Department of Internal Affairs (2001) Reviewing the Local Government Act 1974 - Have your Say, Consultation Document, Department of Internal Affairs, Wellington.

Department of Internal Affairs (2007) Putting Pen to Paper: Creating Partnering Agreements that Work, Department of Internal Affairs, Wellington.

Department of Internal Affairs (2007) Funding Local Government: Report of the Local Government Rates Inquiry, Department of Internal Affairs, Wellington.

Dunedin City Council (2006) Community Plan 2006-2007, viewed on November 2009 at_http://www.dunedin.govt.nz/your-council/policies/tccp.

House of Representatives (2005) Inquiry into the 2004 Local Authority Elections; Report of the Justice and Electoral Committee, Parliament, Wellington.

Local Government Commission (2008) Review of the Local Government Act 2002 and Local Electoral Act 2001, Local Government Commission, Wellington. 
LG Knowhow (2003) The Local Government Act 2002: An Overview, Local Government New Zealand, Wellington.

LG Knowhow (2003) Guide to Decision-Making Guide, Local Government New Zealand, Wellington.

Manukau City Council (2009) Botany Advocacy Plan, viewed on February 2009 at www.manukau.govt.nz.

Manukau City Council (2009) Clevedon Advocacy Plan, viewed on February 2009 at www.manukau.govt.nz.

New Zealand Government (2003) Sustainable Programme of Action for New Zealanders, viewed on March 2006 at www.mfe.govt.nz/publications/sus-dev/sus-dev-programme-of-actionjan03.html

New Zealand Government (2007) Local Government Rates Inquiry: Funding Local Government, Department of Internal Affairs, Wellington.

Office of the Controller and Auditor General (2005) Auditing the Future: Project Update \#8, Office of the Controller and Auditor-General, Wellington.

Office of the Controller and Auditor General (2007) Turning Principles into Action: A Guide for Local Authorities on Decision-making and Consultation, Office of the Controller and Auditor-General, viewed on June 2009 at www.oag.govt.nz.

Office of the Controller and Auditor General (2008) Observations on the Quality of Performance Reporting, Office of the Controller and AuditorGeneral, viewed on July 2009 at www.oag.govt.nz. 
Office of the Controller and Auditor General (2010) Matters Arising from the 2009-19 Long Term Council Community Plans, Office of the Controller and Auditor-General, viewed on August 2010 at www.oag.govt.nz.

Office of the Deputy Prime Minister (2003) The Egan Review: Skills for Sustainable Communities, viewed on 21 March at www.odpm.gov.uk.

Office of the Deputy Prime Minister (2005) Vibrant Local Leadership, Eland House London, viewed on 7 October 2007 at www.odpm.gov.uk.

Office of the Deputy Prime Minister (2004) Sustainable Communities: People, Places and Prosperity: A Five Year Plan from the Office of the Deputy Prime Minister, viewed on 11 November 2009 at: www.odpm.gov.uk.

Office of the Deputy Prime Minister (2006) Devolving Decision-making: 3 Meeting the Regional Economic Challenge: The Importance of Cities to Regional Growth, viewed on 4 May 2008 at www.odpm.gov.uk.

Office of the Deputy Prime Minister (2006) Local Area Agreements: Guidance for Round Three and Refresh of Rounds One and Two, viewed on 17 March 2007 at www.odpm.gov.uk.

Office of the Deputy Prime Minister \& Treasury (2005) Securing Better Outcomes: Developing a New Performance Framework, ODPM Publications, Box 236, Wetherby, West Yorkshire.

Otago Regional Council (2009) Draft LTTCP 2009-2019, Otago Regional Council, viewed on July 2009 at www.orc.govt.nz.

Royal Commission on Auckland Governance (2009) Auckland Governance Report, viewed on 3 April 2009 at www.royalcommission.govt.nz. 
Royal Commission on Social Policy (1988) Towards a Fair and Just Society, Royal Commission on Social Policy, Parliament, Wellington.

State Service Commission (2001) The Review of the Centre, State Services Commission, Parliament, viewed on 6 July 2006 at www.ssc.govt.nz.

State Services Commission (2002) The Review of the Centre One Year On, State Services Commission, viewed on 6 July 2006 at www.ssc.govt.nz. 


\section{Appendix 1: List of New Zealand local authorities ${ }^{99}$}

\begin{tabular}{|c|c|c|c|}
\hline City Councils & Population & Regional Councils & Population \\
\hline Auckland City & 438,100 & Northland Regional & 154,700 \\
\hline North Shore City & 223,000 & Auckland Regional & $1,414,700$ \\
\hline Waitakere City & 201,300 & Bay of Plenty Regional & 269,900 \\
\hline Manukau City & 361,900 & Waikato Regional & 402,200 \\
\hline Hamilton City & 138,500 & Hawke's Bay Regional & 152,800 \\
\hline Tauranga City & 110,500 & Taranaki Regional & 107,500 \\
\hline Napier City & 57,000 & Manawatu Wanganui & 229,200 \\
\hline Palmerston North City & 79,300 & Regional & \\
\hline Porirua City & 51,000 & Wellington Regional & 473,800 \\
\hline Upper Hutt City & 40,200 & Canterbury Regional & 552,900 \\
\hline Hutt City & 101,700 & Otago Regional & 203,500 \\
\hline Wellington City & 192,800 & Southland Regional & 93,000 \\
\hline Nelson City & 44,700 & Westland Regional & 32,400 \\
\hline Christchurch City & 369,000 & & \\
\hline Dunedin City & 123,000 & & \\
\hline Invercargill City & 51,600 & & \\
\hline District Councils & & District Councils & \\
\hline Far North District & 57,900 & Kapiti Coast District & 48,400 \\
\hline Kaipara District & 18,600 & Tasman District & 46,500 \\
\hline Whangarei District & 78,200 & Marlborough District & 44,500 \\
\hline Rodney District & 92,400 & Kaikoura District & 3,770 \\
\hline Papakura District & 48,300 & Chatham Islands & 640 \\
\hline Franklin District & 63,200 & Hurunui District & 10,900 \\
\hline Thames Coromandel & & Waimakariri District & 46,100 \\
\hline District & 26,800 & Selwyn District & 37,500 \\
\hline Hauraki District & 17,700 & Ashburton District & 28,700 \\
\hline Matamata Piako & & Timaru District & 43,900 \\
\hline District & 31,400 & MacKenzie District & 3,950 \\
\hline
\end{tabular}

${ }^{99}$ Estimates for 2008; source www.stats.govt.nz, accessed 26 September 2009. 


\begin{tabular}{|c|c|c|c|}
\hline Western Bay of Plenty & & Waimate District & 7,450 \\
\hline District & 44,400 & Waitaki District & 20,700 \\
\hline Kawerau District & 7,150 & Buller District & 9,960 \\
\hline Whakatane District & 34,400 & Grey District & 13,650 \\
\hline Opotiki District & 9,060 & Westland District & 8,770 \\
\hline Gisborne District & 45,900 & Queenstown Lakes & \\
\hline Wairoa District & 8,480 & District & 26,400 \\
\hline Waikato District & 46,800 & Central Otago District & 17,700 \\
\hline Waipa District & 44,700 & Clutha District & 17,350 \\
\hline South Waikato District & 22,800 & Gore District & 12,250 \\
\hline Rotorua District & 68,100 & Southland District & 29,100 \\
\hline Otorohanga District & 9,220 & & \\
\hline Waitomo District & 9,600 & & \\
\hline Taupo District & 33,400 & & \\
\hline New Plymouth District & 71,800 & & \\
\hline Stratford District & 9,100 & & \\
\hline South Taranaki & & & \\
\hline District & 26,800 & & \\
\hline Ruapehu District & 13,650 & & \\
\hline Wanganui District & 43,400 & & \\
\hline Rangitikei District & 14,950 & & \\
\hline Hastings District & 73,900 & & \\
\hline Central Hawke's Bay & & & \\
\hline District & 13,300 & & \\
\hline Tararua District & 17,750 & & \\
\hline Masterton District & 23,200 & & \\
\hline Carterton District & 7,360 & & \\
\hline South Wairarapa & & & \\
\hline District & 9,190 & & \\
\hline Manawatu District & 29,300 & & \\
\hline Horowhenua District & 30,600 & & \\
\hline
\end{tabular}




\section{Appendix 2: Map of local government boundaries}

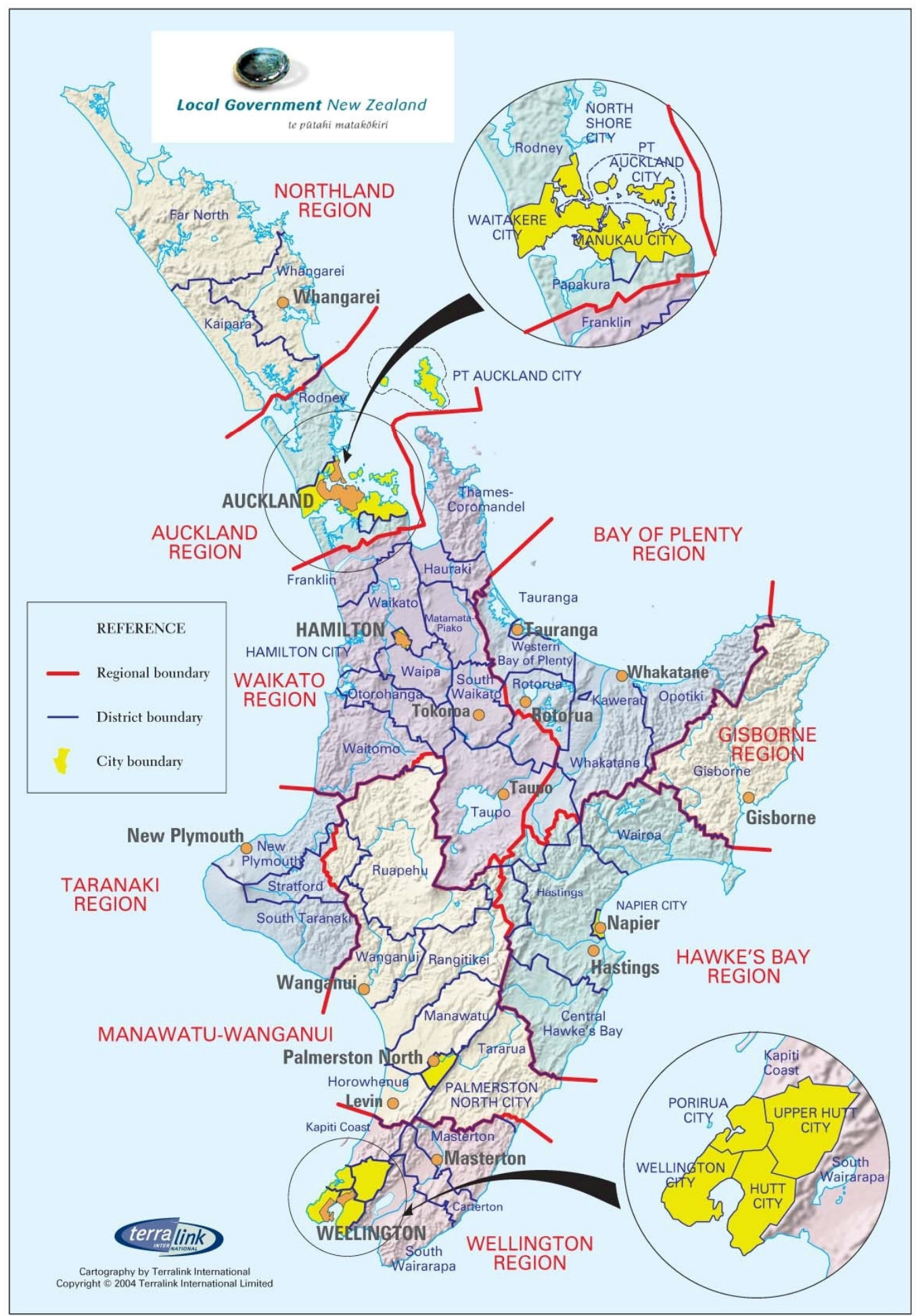




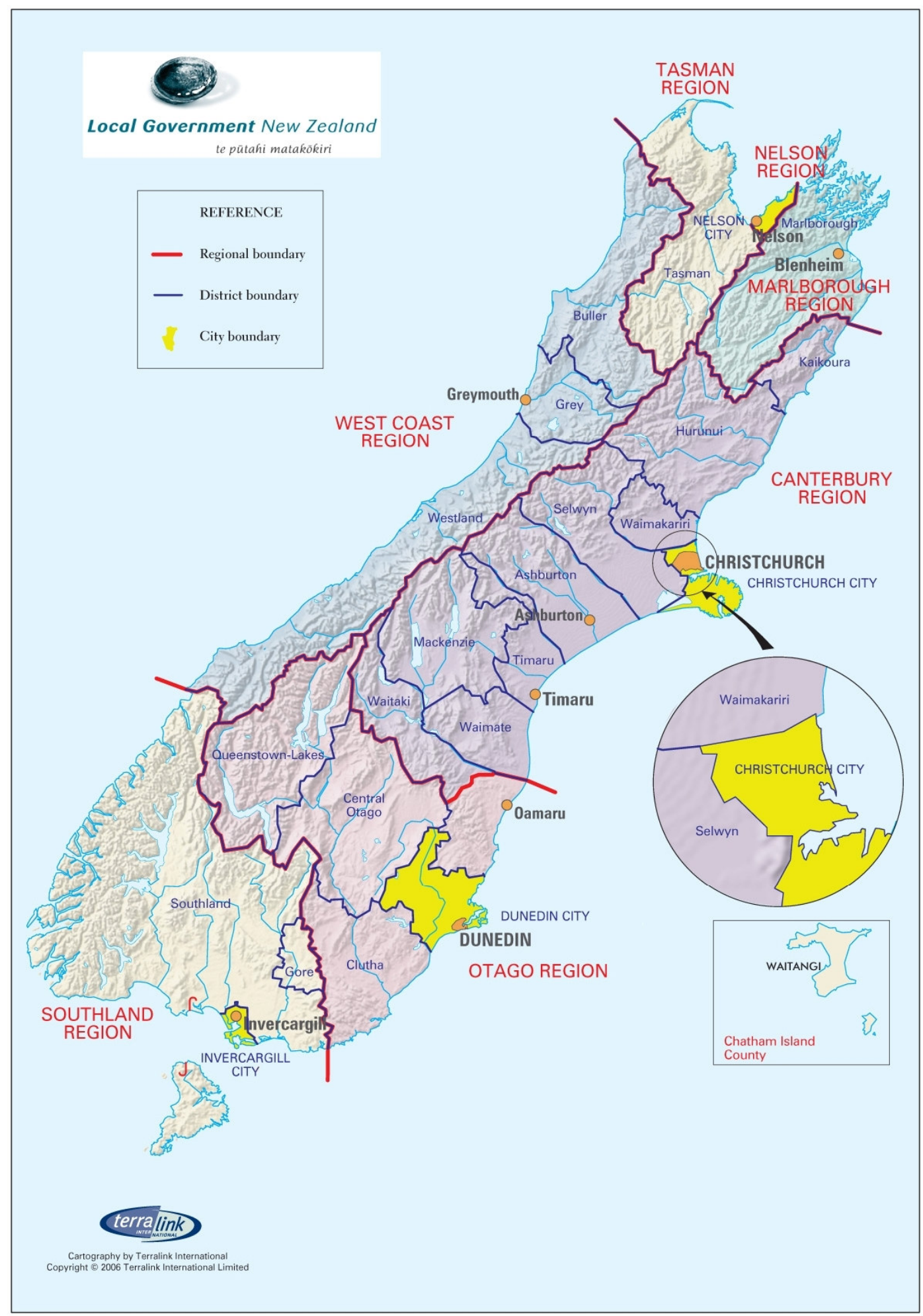




\section{Appendix 3: The Royal Commission on Auckland Governance}

Below are the key recommendations proposed by the Royal Commission on Auckland Governance:

- The Auckland Council should include a vision for the region in its spatial plan.

- The Mayor of Auckland's annual 'State of the Region' address should describe progress towards the attainment of the vision.

- The Auckland Council should adopt a comprehensive regional economic development plan and an associated funding plan.

- The Auckland Councils should establish ... a high level, regional crosssectoral board comprising representatives of central government, local councils, business, education and not-for-profit organisations.

- A Social Issues Board should be established as the main governance body for social issues, with central government membership.

- The Social Issues Board should develop a Social Well-Being strategy and implementation/funding plan.

- A Social Issues Advisory Group of officials should be established to support the Social Issues Board. It should be co-funded by central and local government with responsibilities as described (in Chapter 9).

- The Auckland Council should centre on providing leadership and facilitating improved social well-being outcomes. Direct delivery of social well-being services by Auckland Council should not duplicate central government responsibilities and should be part of the Social Well-being Strategy and implementation/funding plan.

- The Government should give consideration to aligning geographic boundaries of local government and central government agencies responsible for the delivery of social well-being services. 
- The Auckland City Council should establish two advisory panels, one relating to the arts and the other to recreation. With the assistance of the advisory panels it should develop strategies for regional arts and recreation activities and their associated funding.

- The Government should give consideration to the introduction of a fouryear electoral term for local authorities in New Zealand.

- A unitary authority, to be called the Auckland Council, should be formed to assume all local government responsibilities for the Auckland region.

- When the Auckland Council is established, the following existing local authorities should be abolished: Rodney District Council; North Shore City Council; Waitakere City Council; Auckland City Council; Manukau City Council; Papakura District Council; Franklin District Council; Auckland Regional Council.

- The Auckland Council should operate and have representation at two levels: the elected Auckland Council and six local councils.

- The staff from the eight abolished councils should be transferred to the Auckland Council, at least initially.

- The Establishment Board should develop the proposed structure of the elected Auckland Council and local councils (including the committee structure and advisory panels and groups).

- That the Auckland Council should comprise 23 councillors elected or appointed as follows:

- 10 councillors elected at large

- eight councillors elected in four urban wards

- two councillors elected in two rural wards

- two councillors elected at large by voters on the Maori elected roll

○ one councillor appointed by the Mana Whenua Forum.

- The role and functions of the Auckland Council should be prescribed for unitary authorities under the LGA 2002 and other legislation, and as may 
be additionally prescribed in any future legislation referring specifically to the Auckland Council or any of the abolished local authorities.

- The relationship between Auckland Council and each local council should be governed by a three-yearly governance agreement negotiated in the year following each local election.

- The Government should enter into a partnership agreement with the Auckland Council and appoint a senior Cabinet Minister as Minister for Auckland: in addition it should appoint a Cabinet Committee for Auckland comprising ministers with portfolios of significance to Auckland. The Cabinet Committee should be supported by an officials committee.

- The functions of the Cabinet Committee for Auckland should include:

○ consulting with the Auckland Council through the Minister for Auckland

- setting priorities for Government spending in Auckland and deciding on the allocation of discretionary spending

- overseeing events of international significance affecting Auckland. 


\section{Appendix 4: Questionnaire}

\section{Victoria \\ UNIVERSITY OF WELLINGTON \\ Te Whare Wānanga \\ o te Ūpoko o te Ika a Māui

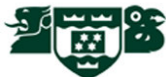

Scenarios for Discussion

CONSENT TO PARTICIPATE IN THE RESEARCH

\section{Project Title:}

\section{An Assessment of Alternative Institutional Arrangements}

\section{to Promote Strategic Local Governance in New Zealand}

I have been given and understood the explanation of this research project. I had an opportunity to ask questions and have them answered to my satisfaction.

I understand that I may withdraw myself (or any information I have

Please circle the appropriate answer:

YES NO provided) from this project before [date], when data collection will complete, without having to give reasons.

I understand that the information I provide will be kept confidential to the researcher and his supervisors. The published results will not use my name and no opinions will be attributed to me in any way that will identify me. I understand that the notes from my interview will be destroyed at the end of the project.

I understand that the data I provide will not be used for any other purpose or released to others without my written consent.

I would like to receive a summary of the results of this research when it is completed.

I agree to take part in this research:

Signature:

Name of participant:

Date: 


\section{Information Sheet}

\section{Dear Participant}

Thank you for agreeing to take part in this survey which will assist me to complete my $\mathrm{PhD}$ thesis. The title is "An Assessment of Alternative Institutional Arrangements to Promote Strategic Local Governance in NZ". The thesis involves an analysis of the New Zealand approach to local governance and an assessment of options for its enhancement, and your participation will assist me to identify potential enhancements. The outcomes of this research will be made available to officials so they can gain further information and influence the future shape of local government policy.

Your participation is expected to take between 45 and 60 minutes all together. This involves reading:

- a one page outline about the nature of community governance (Attachment 1);

- a summary of three options for different community governance arrangements (Attachment 2);

- a detailed breakdown of the three options (Attachment 3)

- a questionnaire (Attachment 4).

A further 30 minutes will be required to participate in a discussion, facilitated by the researcher. Following this discussion you will be able to add further information to your written replies. Your names will not be recorded. The only information required for the survey is information on the type of council you come from and your role, that is, whether you are an elected member or an official.

My $\mathrm{PhD}$ will be completed by mid 2009. I will be providing an electronic copy of my thesis to anyone who requests it. If you wish to acquire a copy of the completed thesis, or a copy of the aggregated research results, or need any further information please contact me directly. 
Please note:

- This research has received approval from the University's Pipitea Human Ethics Committee.

- Participants may withdraw from the research at any stage.

- Individual responses to the survey will be kept completely confidential, only the aggregated results will be used in the research.

\section{Researcher:}

Mike Reid

palmer.family@paradise.net.nz

\section{Supervisor}

Prof. Claudia Scott

Claudia.scott@vuw.ac.nz 


\title{
An Assessment of Alternative Institutional Arrangements to Promote Strategic Local Governance in New Zealand
}

\begin{abstract}
Background
What will local government be like in the 21 st century? Can we assume that the way communities have been governed for the last 150 years will work as well in the new millennium? Confronted with these questions governments throughout the world have been engaged in a policy debate which has ongoing implications about the manner in which their towns, cities and regions are governed.

Emerging from these debates has been a range of new approaches towards local and regional governance, such as the idea of 'community governance', which places emphasis on local government's leadership role and the achievement of outcomes, rather than purely service provision. Community governance is seen as offering a new approach to local government - one that recognises that councils must work with other agencies in order to create sustainable communities.

Community governance provides a 'joined-up' response to local and regional issues and is driven by outcomes defined by citizens rather than higher level government. Councils that adopt the concept of community governance tend to have:

- a willingness to focus on outcomes for the complete jurisdiction over which the authority has responsibility

- a focus on the development of a community vision able to bring together multiple organisations which contribute to local outcomes

- approaches to decision-making that are participatory and inclusive

- a willingness to employ a diversity of roles beyond that of service provider

- a focus on issues of co-ordination.
\end{abstract}

You are invited to fill in this questionnaire and take part in a discussion about this new approach and how it might be strengthened in New Zealand and in particular any obstacles that might need to be addressed.

I am completing a PhD at the School of Government at Victoria University and your views will assist me with my research. In addition, the research will be made public and I will be sharing my findings on local government reform with the full local government sector.

Mike Reid

PhD Student

School of Government

Victoria University 


\title{
ATTACHMENT 2
}

\section{Option Summaries}

\author{
Option 1 (Athens)
}

This option is categorised by the creation of consolidated unitary local authorities (bringing together the functions of territorial and regional councils). Recognising the larger scale and thus competence of the new authorities the Government has pursued an active policy of devolution to local government, passing down many of its public health functions, responsibility for child and youth services, and support for the elderly. To reflect their new responsibilities councils have been given access to a local income tax to supplement rates. 'Equalisation' grants are provided to councils representing low socio-economic communities.

Councils continue to operate according to the decision-making rules outlined in the LGA 2002 except for the introduction of mandatory referenda through which voters can overturn council decisions or trigger another election. This additional accountability has been welcomed and was introduced after concerns were expressed that the local income tax would be too costly. More contentiously, however, the practice of adopting national policy statements has been extended to include more areas of council activity.

\section{Option 2 (Sparta)}

In this scenario council boundaries have been largely retained however, following concerns about accountability and lack of representation some de-amalgamation has taken place. Elected regional councils were replaced by regional organisations of councils made up of council representatives and which are being given responsibility for territorial functions that benefit from the economies of scale, such as the provision of potable water and wastewater services. This has led to greater diversity in the nature of services provided by local authorities.

To strengthen the responsiveness of councils the minimum number of elected members on a council has been increased to 10 and community boards are mandatory for any council with a population larger than 20,000. To ensure government programmes reflect local priorities all government departments providing services to localities must provide councils with the opportunity to comment on their proposed work programmes and give reasons for not adopting council proposals.

\section{Option 3 (Rome)}

The structure of local government remains much the same, gradually changing over time in response to local and regional pressures. In recognition of the complex and difficult issues facing communities the Government has moved to align the boundaries of its departments and agencies with those of local and regional councils. This was the first step in a process of stronger 'joined-up' government that has also seen the development of a comprehensive national plan to better steer local authorities and other agencies delivering public services.

In response to concerns over the adequacy of their taxing powers the Government has addressed councils' concerns by allowing them to submit bids for project/discretionary 
spending as formal part of its annual budget process, in competition with government departments. Also reflecting new responsibilities allocated to councils the Government has introduced a new model for joined-up services which it calls Local Area

Agreements (LAAs). These are place-based mechanisms which bring together local and national agencies acting to achieve the same outcomes in order to agree common targets. They may also involve 'pooled' funding. In addition, the Government is considering a proposal to appoint its own representatives on to each council in order to assist with alignment. 
ATTACHMENT 3

\section{Detailed Options}

\begin{tabular}{|c|c|c|c|c|c|}
\hline & $\begin{array}{l}\text { Range of } \\
\text { services }\end{array}$ & $\begin{array}{l}\text { Structure and } \\
\text { form }\end{array}$ & $\begin{array}{l}\text { Interface with } \\
\text { higher } \\
\text { governments, } \\
\text { and others }\end{array}$ & Revenue & $\begin{array}{l}\text { Opportunities } \\
\text { for citizen } \\
\text { involvement }\end{array}$ \\
\hline $\begin{array}{c}\text { Option } \\
1 \\
\text { (Athens) }\end{array}$ & $\begin{array}{l}\text { New services } \\
\text { devolved to } \\
\text { councils, for } \\
\text { example: } \\
\text { Public health } \\
\text { Age care } \\
\text { Child care } \\
\text { After-school } \\
\text { care }\end{array}$ & $\begin{array}{l}\text { Consolidation } \\
\text { Unitary councils } \\
\text { with } \\
\text { community } \\
\text { boards or } \\
\text { equivalent } \\
\text { mandatory }\end{array}$ & $\begin{array}{l}\text { National } \\
\text { policy } \\
\text { statements } \\
\text { and standards } \\
\text { extended } \\
\text { across all } \\
\text { council } \\
\text { activities. }\end{array}$ & $\begin{array}{l}\text { Rates plus } \\
\text { regional } \\
\text { income tax } \\
\text { with } \\
\text { 'equalisation' } \\
\text { grants for } \\
\text { councils with } \\
\text { low socio- } \\
\text { economic } \\
\text { communities. }\end{array}$ & $\begin{array}{l}\text { Maintain LGA } \\
2002 \\
\text { provisions } \\
\text { plus option for } \\
\text { binding } \\
\text { referenda on } \\
\text { major projects } \\
\text { including } \\
\text { ability to } \\
\text { trigger a fresh } \\
\text { election }\end{array}$ \\
\hline $\begin{array}{l}\text { Option } 2 \\
\text { (Sparta) }\end{array}$ & $\begin{array}{l}\text { More diversity } \\
\text { as metropolitan } \\
\text { areas demand } \\
\text { greater } \\
\text { devolution. } \\
\text { Smaller TAs } \\
\text { focus on } \\
\text { functions with } \\
\text { defined areas } \\
\text { of benefit. } \\
\text { Some } \\
\text { functions } \\
\text { transferred to } \\
\text { regional } \\
\text { organisations } \\
\text { of councils }\end{array}$ & $\begin{array}{l}\text { Deconsolidation } \\
\text { Regional } \\
\text { councils have } \\
\text { been replaced } \\
\text { by voluntary } \\
\text { 'regional } \\
\text { organisations of } \\
\text { councils' } \\
\text { established as } \\
\text { required. }\end{array}$ & $\begin{array}{l}\text { Government } \\
\text { departments } \\
\text { and agencies } \\
\text { required to } \\
\text { take into } \\
\text { account local } \\
\text { and regional } \\
\text { outcomes } \\
\text { when } \\
\text { preparing } \\
\text { annual } \\
\text { budgets and } \\
\text { work plans }\end{array}$ & $\begin{array}{l}\text { Status quo } \\
\text { with } \\
\text { equalisation } \\
\text { grants for } \\
\text { councils with } \\
\text { low socio- } \\
\text { economic } \\
\text { communities }\end{array}$ & $\begin{array}{l}\text { Smaller local } \\
\text { authorities } \\
\text { provide } \\
\text { greater } \\
\text { proximity } \\
\text { between } \\
\text { elected } \\
\text { members and } \\
\text { citizens }\end{array}$ \\
\hline $\begin{array}{l}\text { Option } 3 \\
\text { (Rome) }\end{array}$ & $\begin{array}{l}\text { Increasing use } \\
\text { of integrated } \\
\text { service } \\
\text { delivery } \\
\text { arrangements } \\
\text { e.g. road } \\
\text { maintenance } \\
\text { and } \\
\text { construction } \\
\text { partnerships } \\
\text { between } \\
\text { councils and } \\
\text { Land Transport } \\
\text { New Zealand }\end{array}$ & $\begin{array}{l}\text { Little change. } \\
\text { Government } \\
\text { departments } \\
\text { establish } \\
\text { regional } \\
\text { presence to } \\
\text { liaise with } \\
\text { regional and } \\
\text { territorial } \\
\text { authorities. }\end{array}$ & $\begin{array}{l}\text { Joint planning } \\
\text { and budgeting } \\
\text { through Local } \\
\text { Area } \\
\text { Agreements } \\
\text { as well as } \\
\text { possible } \\
\text { central } \\
\text { government } \\
\text { appointments } \\
\text { on local } \\
\text { government }\end{array}$ & $\begin{array}{l}\text { Opportunities } \\
\text { for joint } \\
\text { local/central, } \\
\text { government } \\
\text { funding of } \\
\text { local } \\
\text { initiatives. } \\
\text { Councils have } \\
\text { right to make } \\
\text { direct bids for } \\
\text { a share of the } \\
\text { central } \\
\text { government } \\
\text { budget. }\end{array}$ & $\begin{array}{l}\text { Formal } \\
\text { opportunities } \\
\text { to participate } \\
\text { around } \\
\text { structured } \\
\text { long-term } \\
\text { planning } \\
\text { processes }\end{array}$ \\
\hline
\end{tabular}




\section{Questions}

\section{ATTACHMENT 4}

Bearing in mind the discussion about community governance outlined above and the proposed options can you please answer the following questions:

1 Please list what you see as the strengths and weaknesses of the Athens option.

\begin{tabular}{|c|c|}
\hline Strengths & Weaknesses \\
\hline & \\
& \\
& \\
\hline
\end{tabular}

2 Please list what you see as the strengths and weaknesses of the Sparta option.

\begin{tabular}{|c|c|}
\hline Strengths & Weaknesses \\
\hline & \\
& \\
& \\
\hline
\end{tabular}

3 Please list what you see as the strengths and weaknesses of the Rome option.

\begin{tabular}{|c|c|}
\hline Strengths & Weaknesses \\
\hline & \\
& \\
& \\
\hline
\end{tabular}


$4 \quad$ Please rank the Options for their ability to strengthen community governance with your most favoured option at the top, explaining why.

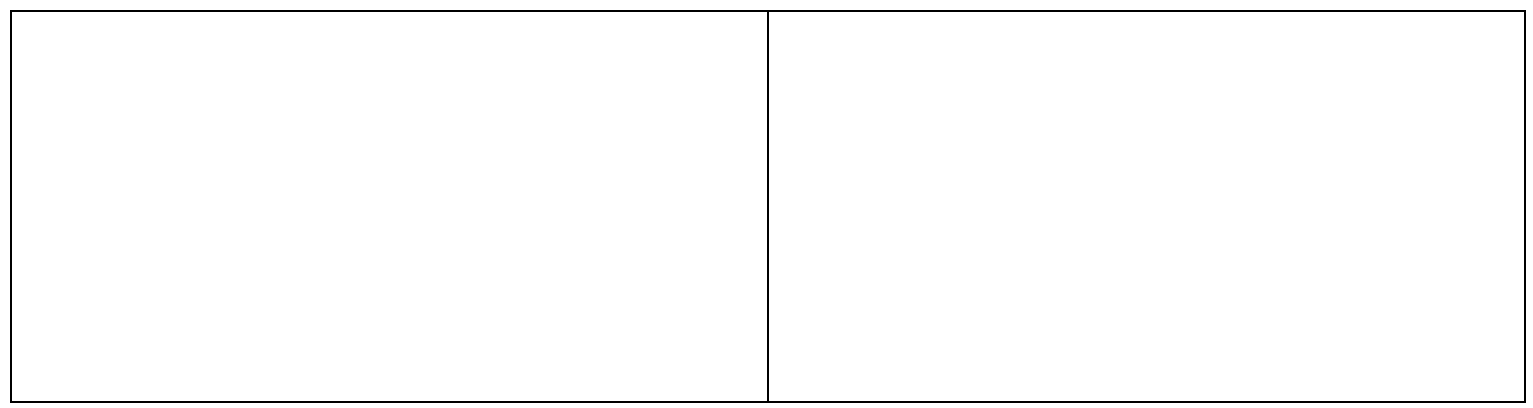

$5 \quad$ Please list any other changes you believe are necessary to strengthen the ability of the New Zealand local government system to achieve community governance.

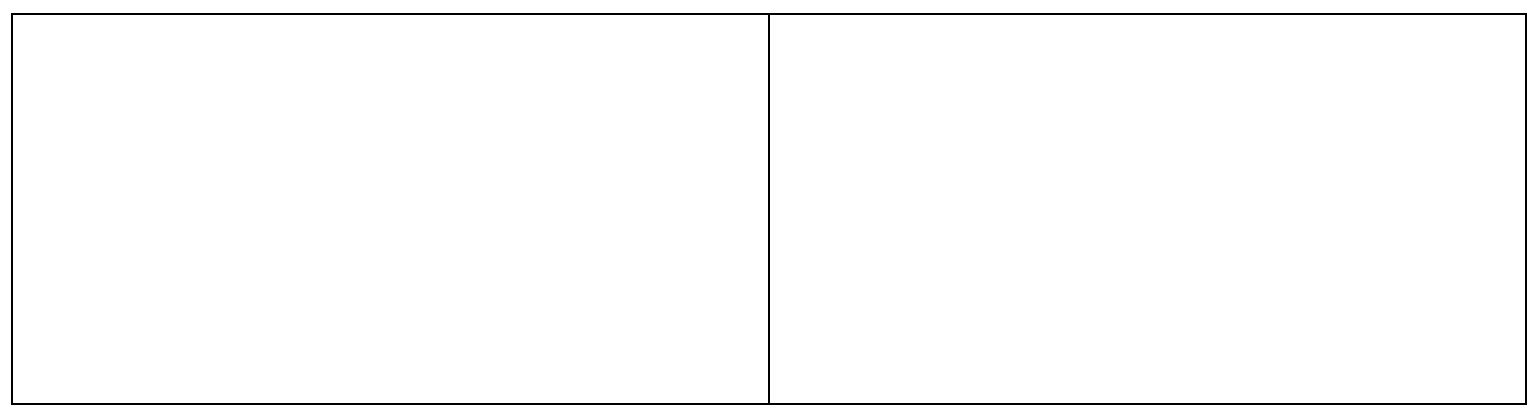

The results of this survey will be treated with strict confidentiality. To assist me analyse the results can you please fill in the following information.

\section{Respondent Profile}

\begin{tabular}{|c|c|c|c|}
\hline Position & Tick & Council & tick \\
\hline Elected & & Territorial/unitary & \\
\hline Official & & Regional & \\
\hline
\end{tabular}

\section{District/City/Regional Population}

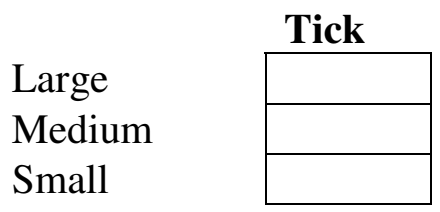

PS If you would like to email me any further comments please do. My email is palmer.family@paradise.net.nz 